\title{
Geologic and Hydrologic Investigations of a Potential Nuclear Waste Disposal Site at Yucca Mountain, Southern Nevada
}

\author{
By MICHAEL D. CARR and JAMES C. YOUNT, Editors
}

USGS-BULL- -1790

TI89 003048

\section{DISCLAIMER}

This report was prepared as an account of work sponsored by an agency of the United States Government. Neither the United States Government nor any agency thereof, nor any of their employees, makes any warranty, express or implied, or assumes any legal liability or responsibility for the accuracy, completeness, or usefulness of any information, apparatus, product, or process disclosed, or represents that its use would not infringe privately owned rights. Reference herein to any specific commercial product, process, or service by trade name, trademark, manufacturer, or otherwise does not necessarily constitute or imply its endorsement, recommendation, or favoring by the United States Government or any agency thereof. The views and opinions of authors expressed herein do not necessarily state or reflect those of the United States Government or any agency thereof. 


\title{
DEPARTMENT OF THE INTERIOR DONALD PAUL HODEL, Secretary
}

\author{
U.S. GEOLOGICAL SURVEY \\ Dallas L. Peck, Director
}

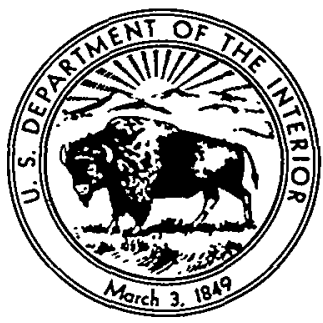

For sale by the

Books and Open-File Reports Section

U.S. Geological Survey

Federal Center, Box 25425

Denver, CO 80225

Library of Congress Cataloging-in-Publication Data

Geologic and hydrologic investigations of a potential nuclear waste disposal site at Yucca Mountain, southern Nevada.

U.S. Geological Survey Bulletin 1790

Includes bibliographies.

Supt. of Docs. No.: I 19.3:1790

1. Geology-Nevada-Yucca Mountain Region. 2. HydrologyNevada-Yucca Mountain Region. 3. Radioactive waste disposal in the ground-Nevada-Yucca Mountain Region. I. Carr, Michael D. II. Yount, James C. III. Series. 


\section{DISCLAIMER}

Portions of this document may be illegible in electronic image products. Images are produced from the best available original document. 


\section{PREFACE}

Yucca Mountain in southern Nye County, Nevada, has been selected by the United States Department of Energy as one of three potential sites for the nation's first high-level nuclear waste repository. Its deep water table, closed-basin ground-water flow, potentially favorable host rock, and sparse population have made the Yucca Mountain area a viable candidate during the search for a nuclear waste disposal site. Yucca Mountain, however, lies within the southern Great Basin, a region of known contemporary tectonism and young volcanic activity, and the characterization of tectonism and volcanism remains as a fundamental problem for the Yucca Mountain site.

The United States Geological Survey has been conducting extensive studies to evaluate the geologic setting of Yucca Mountain, as well as the timing and rates of tectonic and volcanic activity in the region. A workshop was convened by the Geological Survey in Denver, Colorado, on August 19, 20, and 21, 1985, to review the scientific progress and direction of these studies. Considerable debate resulted. This collection of papers represents the results of some of the studies presented at the workshop, but by no means covers all of the scientific results and viewpoints presented. Rather, the volume is meant to serve as a progress report on some of the studies within the Geological Survey's continuing research program toward characterizing the tectonic framework of Yucca Mountain.

Much of the work is being done under a cooperative agreement with the Department of Energy's Nevada Nuclear Waste Storage Investigations program; the remainder of the work is part of ongoing Geological Survey programs in the southern Great Basin that have resulted in findings pertinent to the waste isolation problem. 


\section{CONTENTS}

1. Introduction $\mathbf{1}$

By Michael D. Carr and James C. Yount

2. Regional geologic and geophysical maps of the southern Great Basin 3

By Thomas G. Hildenbrand, Albert M. Rogers, Howard W. Oliver, Stephen C.

Harmsen, John K. Nakata, Douglas S. Aitken, Robert N. Harris, and

Michael D. Carr

3. Preliminary interpretation of seismic-refraction and gravity studies west of Yucca Mountain, Nevada and California 23

By Hans D. Ackermann, Walter D. Mooney, David B. Snyder, and Vickie D. Sutton

4. Volcano-tectonic setting of Yucca Mountain and Crater Flat, southwestern

Nevada 35

By Wilfred J. Carr

5. Detachment faulting in the Death Valley region, California and Nevada $\mathbf{5 1}$

By Warren B. Hamilton

6. Stress field at Yucca Mountain, Nevada 87

By Joann M. Stock and John H. Healy

7. An evaluation of the topographic modification of stresses at Yucca Mountain, Nevada 95

By Henri S. Swolfs, William Z. Savage, and William L. Ellis

8. Preliminary study of Quaternary faulting on the east side of Bare Mountain, Nye County, Nevada 103

By Marith C. Reheis

9. Reinterpretation of the Beatty scarp, Nye County, Nevada 113

By W C Swadley, James C. Yount, and Samuel T. Harding

10. Preliminary results of high-resolution seismic-reflection surveys conducted across the Beatty and Crater Flat fault scarps, Nevada 121

By Samuel T. Harding

11. Uranium-trend dating of fluvial and fan deposits in the Beatty area, Nevada 129

By John N. Rosholt, W C Swadley, and Charles A. Bush

12. Relation between $P$-wave velocity and stratigraphy of late Cenozoic deposits of southern Nevada 139

By Eduardo A. Rodriguez and James C. Yount

13. Water-table decline in the south-central Great Basin during the Quaternary: implications for toxic waste disposal 147

By Isaac J. Winograd and Barney J. Szabo

Any use of trade names is for descriptive purposes only and does not imply endorsement by the U.S. Geological Survey. 


\title{
1. Introduction
}

\author{
By Michael D. Carr and James C. Yount
}

Tectonic setting has emerged as an important issue during site selection for many nuclear facilities. It also will be an important issue in the selection of the nation's first site for the disposal of high-level nuclear waste. The potential for tectonic or volcanic activity that could adversely affect the performance of a repository is listed specifically by the Nuclear Regulatory Commission as a potentially adverse condition under siting criteria in the Code of Federal Regulations.

Many questions regarding tectonism will not be answered uniquely. Questions of broad scope, such as what region constitutes the tectonic setting of significance to the proposed site and what is the character of tectonism in the regional setting, include topics that are at the leading edge of current scientific debate. More specific questions, such as what are the setting and history of young faults near enough to the proposed site to produce consequential ground shaking, what is the state of stress throughout the rock column at the site, and what are the maximum earthquake magnitudes and the maximum ground accelerations expected at the site, press the limit of current theory and research techniques. Realistically planners will need to accept a range of interpretations of the site geology in keeping with current concepts of the regional geologic framework, evaluating safe waste isolation in light of every credible hypothesis.

Tectonic setting is an especially pertinent issue for the Yucca Mountain site because the site lies within the southern Great Basin, a region of known active tectonism and young volcanism. Some scientists have emphasized the relationship between tectonism and volcanism in the region that includes Yucca Mountain. Could future tectonism induce volcanism or vice versa? The relationships between tectonism and other geologic factors important to site evaluation also are important issues. For instance, the stability of the deep ground-water table is critical to plans for a repository at Yucca Mountain: could future tectonism alter the character of the hydrologic system beneath the proposed site?

Members of the U.S. Geological Survey conducting investigations in the southern Great Basin (including many of those directly involved in the evaluation of the Yucca Mountain site) met in Denver, Colorado, in August 1985 to review available geologic and geophysical data for the region. Much discussion centered on current concepts of regional crustal extension in the southern Great Basin. Considerable discussion centered, as well, on methods for determining the state of stress in and around Yucca Mountain and on the results of ongoing stress studies. Geologic, geophysical, and geochemical techniques for establishing the age of Quaternary deposits in the region also were examined in detail because of their importance for determining the movement history of young faults near Yucca Mountain.

Crustal extension has been the principal tectonic process affecting the southern Great Basin during the late Cenozoic. Questions focused on the mechanisms of extension, the temporal and spatial distribution of extension, and the amounts and rates of extension. Surface geology is reasonably well known for much of the southern Great Basin, but deep crustal structure is not well known.

Many of the tectonic models for the southern Great Basin emphasize detachment faulting as a fundamental mechanism for extension. Most of the attendees concurred that the detachment faults exposed in the region played a key role during regional Miocene extension, but there was considerable disagreement concerning the geometry and significance of such faults in the contemporary tectonic framework.

Some researchers contended that contemporary extension is merely a continuation of Miocene extension and that the geometry of extension has not changed significantly during the past 15 million years. While some of these workers cited waning volcanism as evidence that the rate of tectonic activity in the region also is slowing, others cited areas of extreme active tectonism such as Death Valley as evidence of continuing regional extension in the southern Great Basin. Still others contended that major changes have occurred in the extensional framework of the southern Great Basin during the late Cenozoic. These researchers suggested that although contemporary fault movement may be in response to processes similar to those controlling Miocene structures, the geometry and rates of contemporary movement on faults formed during the Miocene, as well as on newly formed faults, are not wholly related to the Miocene framework and must be viewed independently.

There was general agreement among the researchers that numerous interpretations are permissible under the constraints of our current knowledge of surface geology and that acquisition of regional subsurface data will be important in evaluating these hypotheses. Determining whether the extensional setting has been uniform since the middle Miocene, or whether there have been major changes in the regional structural setting since extension began, is fundamental to predicting the nature of future faulting and volcanic activity near Yucca Mountain. If the extension occurring today reflects the same tectonic setting as in the Miocene, then it may be valid to incorporate Miocene history into predictions of future tectonism. If, however, the tectonic setting has changed significantly since the late Miocene, then only the most recent tectonic episode can be incorporated into 
predictive tectonic analyses. Establishing an age for the beginning of the contemporary tectonic episode thus becomes an especially important problem facing investigators.

Just as tectonic activity may not have been uniform in time, so it appears not to have been uniform in space; for example, recent deformation in the Death Valley region, west of the Furnace Creek fault zone, apparently is more severe than in the region farther east, closer to Yucca Mountain. Some researchers noted this as evidence for relative tectonic stability of the area that includes Yucca Mountain with respect to other parts of the Great Basin. Documenting the rates of tectonic activity and defining the structural boundaries between contemporary tectonic domains in the region also are important to making geologic predictions of future tectonism for Yucca Mountain. For example, if meaningful strain rates for structures in the Yucca Mountain area are to be determined, then such rates can be calculated only on the basis of data demonstrably from the structural domain that includes Yucca Mountain. Furthermore, it is important to understand the extent to which tectonic domains in the region are mechanically independent from, or interactive with, one another.

Focal mechanisms determined from current seismicity are consistent with the recognition of active crustal extension in the region that includes Yucca Mountain, but the correspondence between earthquake epicenters and surface structures is weak. There is a slight tendency for earthquakes to be more abundant in regions with young faults, except in the Death Valley area. Measurements of the active stress field at Yucca Mountain also are consistent with active extension.

Much of the current emphasis of tectonic research sponsored by the nuclear waste program focuses not on the regional tectonic setting, but rather on the history of specific young faults in the vicinity of Yucca Mountain. Recent discoveries by some of the researchers at the meeting demonstrate recurrent movement during the Quaternary on several fault systems near Yucca Mountain and possible Holocene displacement on at least two of these.

Precise dating of Quaternary materials offset by faults remains a critical problem in determining the history of faulting, which is the basis for predicting future fault activity. Most of the dates defining the chronology of the Quaternary structural history of the Yucca Mountain area were done by the uranium-trend method, an experimental technique whose accuracy in specific cases was strongly debated at the meeting. Clearly, a variety of dating techniques must be used to refine the Quaternary stratigraphy of Yucca Mountain. In order to do this, a regional approach is needed, because directly datable materials are sparse at Yucca Mountain.

A major topic of the Denver meeting was additional research needs and directions. The need for a thorough regional understanding of the tectonic setting of Yucca Mountain was emphasized. Studying Yucca Mountain out of context likely would lead to an inadequate level of understanding for licensing a repository when the site is placed under the scrutiny of the scientific community.

The significance of detachment faulting, identification of contemporary structural domains, and determination of strain rates and patterns are problems that must be appreciated on a regional scale. Regional tectonic framework studies will require additional regional map compilation and then detailed mapping of critical areas, along with further integration of geological and geophysical data. Regional seismic-refraction and seismic-reflection surveys have proved to be the most valuable tools in many cases for better constraining the relation between structures mapped at the surface and the subsurface structural framework. Regional understanding of strain patterns and rates will require further paleostress studies, in-situ stress measurements, paleomagnetism studies, and isotopic dating to help determine uplift rates and histories. Studies of Cenozoic sedimentary basins were recommended for comparison of Miocene basin configuration with that of present-day basins to test continuity of structural geometry and help establish age control for major tectonic features.

Detailed Quaternary fault studies must continue along with studies to refine the stratigraphy of Quaternary deposits. Testing of experimental dating techniques and duplication of dates by various techniques are critical to establishing the rates of contemporary faulting in the vicinity of Yucca Mountain. The Furnace Creek fault was emphasized as one deserving additional study, because it is the longest fault in the vicinity of Yucca Mountain and because it appears to be a major structural boundary between contemporary tectonic domains.

An understanding of the local geology of Yucca Mountain and credible prediction of geologic boundary conditions for engineering purposes are dependent on our thorough appreciation of the regional geologic and geophysical setting, as well as detailed site-specific studies. Tectonism in the southern Great Basin is in response to processes on a global scale and cannot be understood except in a regional context.

As conveners of the Denver meeting we wish to thank all of the participants. We especially thank Ernest E. Anderson, Manuel G. Bonilla, Jerry P. Eaton, Warren B. Hamilton, and John H. Stewart, who served as a panel of experts to evaluate our ongoing research program. 


\title{
2. Regional Geologic and Geophysical Maps of the Southern Great Basin
}

\author{
By Thomas G. Hildenbrand, Albert M. Rogers, Howard W. Oliver, \\ Stephen C. Harmsen, John K. Nakata, Douglas S. Aitken, \\ Robert N. Harris, and Michael D. Carr
}

\section{CONTENTS}

\author{
Abstract 3 \\ Introduction 3 \\ Quaternary faults 3 \\ Contemporary seismicity 4 \\ Terrain maps $\mathbf{5}$ \\ Terrain data 5 \\ Slope $\mathbf{5}$ \\ Gravity anomaly maps 5 \\ Free-air and Bouguer gravity anomalies 5 \\ Separating the regional and residual gravity anomaly 6 \\ Isostatic residual gravity map 6 \\ Magnetic anomaly maps 8 \\ Total-intensity residual magnetic field 8 \\ First-vertical-derivative operation 8 \\ Pseudo-gravity gradient 8 \\ References cited 9
}

\begin{abstract}
A collection of maps of the southern Great Basin presents an overview of the geologic and geophysical features of the region that contains the proposed site for disposal of high-level nuclear waste at Yucca Mountain in southern Nevada. The collection consists of 1:2,500,000-scale maps of the geology; terrain and terrain slope; Quaternary faults and earthquake epicenters; free air, complete Bouguer, regional, residual, and isostatic residual gravity anomalies; residual total magnetic anomaly; first vertical derivative of the magnetic field; and magnitude of the horizontal gradient of the pseudo-gravity field.
\end{abstract}

\section{INTRODUCTION}

The collection of 1:2,500,000-scale maps of the southern Great Basin presented here gives an overview of the general gravity, aeromagnetic, and terrain features of the region that contains the proposed high-level nuclear waste disposal site at Yucca Mountain in southern Nevada (fig. 2.1). The collection includes a generalized geologic map (fig. 2.2, in pocket) and a map of Quaternary faults and epicenters of contemporary seismic events (fig. 2.3, in pocket) as transparent overlays for comparison with the various geophysical and terrain maps, in order to emphasize spatial relations between regional geologic and geophysical features, terrain, and patterns of contemporary tectonic activity.

No attempt is made here to interpret these maps. Rather, we present the maps as a data source for those attempting to interpret the regional geologic and geophysical framework of the southern Great Basin and the proposed waste disposal site at Yucca Mountain. It is hoped that these maps will assist in identifying the boundaries of the major contemporary tectonic domains in the region surrounding Yucca Mountain. All of the maps use an Albers equal-area conic projection (standard parallels $29.5^{\circ} \mathrm{N}$. and $45.5^{\circ} \mathrm{N}$., central meridian $96^{\circ} \mathrm{W}$. .).

\section{QUATERNARY FAULTS}

Late Cenozoic fault traces (fig. 2.3) were derived from the Quaternary fault map of the Basin and Range and Rio Grande Rift compiled by Nakata and others (1982) and, in the vicinity of Yucca Mountain, from Swadley and others (1984). The compilation of Quaternary faults is presented here principally to show the general pattern and distribution of contemporary faulting for comparison with regional patterns of epicenters of seismic events and as a geologic frame of reference for comparing regional geophysical features.

The Quaternary fault map of Nakata and others was compiled at a scale of $1: 2,500,000$ using data from 55 sources and shows the regional pattern of known Quaternary faulting. Because of the problems inherent in generating a map using data from different sources and map scales, several cautions need to be kept in mind:

1. Adjacent short faults that were mapped at a fine scale commonly are portrayed as a single fault line with an average orientation.

2. The change in fault density from one area to another commonly reflects the intent of the original source maps and may not reflect the true density of faults. For example, a reconnaissance geologic map may not show as many fault traces as a map resulting from a project specifically directed to recognize Quaternary faults. There was no attempt by Nakata and others (1982) to equilibrate the density of faults in areas of similar fault density but disparate mapping. 
3. Strict control over the reliability of fault information from various sources was difficult, and data were therefore taken at face value. Some faults only suspected of Quaternary movement were included for completeness.

\section{CONTEMPORARY SEISMICITY}

Seismic events recorded by the southern Great Basin seismograph network from August 1978 through December
1986 (fig. 2.3) range in local magnitude from about $M_{\mathrm{L}}=0$ to 4 (using a revised magnitude scale presented by Rogers and others, 1986).

The southern Great Basin seismograph network consists of 47 vertical-component seismographs installed during 1978 and 1979 over a region within $160 \mathrm{~km}$ of the proposed nuclear waste repository site at Yucca Mountain (fig. 2.4). Data from this network provide a basis for locating and studying earthquakes to aid in evaluating the seismic hazard at the Yucca Mountain site. The network was designed to

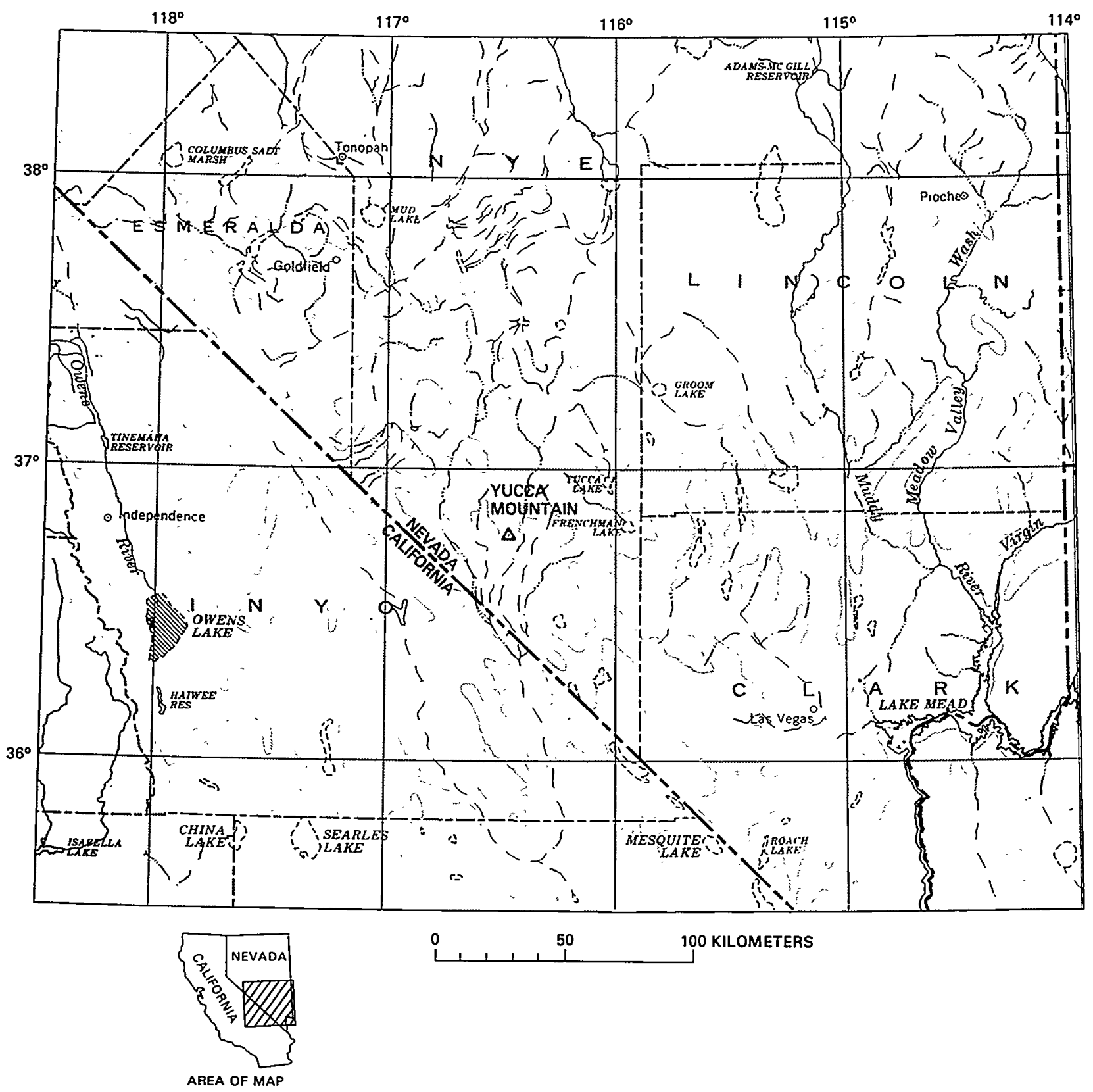

Figure 2.1. Index map of southern Great Basin. Patterned areas are upland areas underlain by bedrock; unpatterned areas are Quaternary basins.

4 Geologic and Hydrologic Investigations, Yucca Mountain, Nevada 
cover the tectonic features suspected to be of greatest significance relative to seismic hazard assessment at Yucca Mountain (Rogers and others, 1983; Carr, 1984).

A six-station supplemental net was deployed on Yucca Mountain in May 1981 in order to lower the detection threshold and to improve location accuracy for earthquakes at the proposed site. During the final half of 1984, horizontalcomponent instruments were deployed at stations PRN, GMR, EPN, GMN, YMT4, LSM, and JON (fig. 2.4). These serve multiple purposes, including enhanced shear-wave arrival time detection, magnitude estimation for larger earthquakes, and earthquake radiation pattern studies.

A PDP $11 / 34$ computer continuously digitized the analog data from this seismograph network and automatically tested for presence of earthquakes. The digital data were stored on magnetic tape and later analyzed on a DEC PDP $11 / 70$ computer. Rogers and others (1987, appendix E) discussed the telemetry and electronics of the network and derived the frequency response curves for all systems used in the network. The combined hardware-software package, including high-resolution graphics display terminals, results in estimation of phase arrival times within 0.01 to 0.02 second. The uniformly high station gains $(84 \mathrm{db}$ ), combined with the processing tools now in use, give the network the capability of locally recording earthquakes having magnitudes as low as $M_{\mathrm{L}}=0.0$ and a region-wide sensitivity of $M_{\mathrm{L}}=1.0$. Develocorder films serve as a continuous backup when the computer fails, due to computer problems such as tape write errors. The computer downtime is about 5 to 6 percent; however, films were scanned for these time periods, and the catalog is essentially complete to roughly $M_{\mathrm{L}}=1.0$. Known mining blasts and nuclear tests have been removed from the catalog.

Earthquake locations have a mean horizontal standard error of about $0.5 \mathrm{~km}$ and mean depth standard error of about $1.0 \mathrm{~km}$. The network spans longitude $114.6^{\circ}$ to $117.8^{\circ} \mathrm{W}$. and latitude $36.0^{\circ}$ to $38.2^{\circ} \mathrm{N}$. Earthquakes located outside this area using data from the network have larger standard errors than the values given above. Furthermore, the earthquake catalog is incomplete outside this area.

\section{TERRAIN MAPS}

\section{Terrain Data}

The terrain map shown on figure 2.5 was plotted from a U.S. Geological Survey digital data base derived from data obtained from the National Geodetic Survey. The National Geodetic Survey received these data from the Defense Department's Electromagnetic Compatibility Analysis Center, whose primary data source was the Defense Mapping Agency Topographic Center.

The original terrain data were generated by digitizing contour lines, spot elevations, and stream and ridgeline elevations from 1:250,000-scale maps, which have contour intervals ranging from 50 to $200 \mathrm{ft}$ ( 15 to $61 \mathrm{~m}$ ). The Electromagnetic Compatibility Analysis Center used the Defense Mapping Agency Topographic Center data and data from other sources to obtain point elevations rounded to the nearest $10 \mathrm{~m}$ for every 30 seconds of latitude and longitude, or approximately every $0.85 \mathrm{~km}$ on the ground. Godson (1981) transformed these 30 -second point-elevation data to average elevations for grid cells 30 seconds on a side by taking a simple average of the elevations of the four corners of each cell.

The 30-second geodetic coordinates of the study area were changed to map coordinates using an Albers equal-area conic projection (standard parallels $29.5^{\circ} \mathrm{N}$. and $45.5^{\circ} \mathrm{N}$., central meridian $96^{\circ} \mathrm{W}$.). Because the machine contouring method requires equally spaced data, elevations were determined at intervals of $2 \mathrm{~km}$ by using a minimum-curvature gridding technique.

\section{Slope}

The terrain-slope map in figure 2.6 was compiled using the following equations:

$$
\begin{gathered}
\text { slope }=\sqrt{\left(\frac{\partial t}{\partial x}\right)^{2}+\left(\frac{\partial t}{\partial y}\right)^{2}} \\
\frac{\partial t}{\partial x}=\frac{t_{i+1, j}-t_{i-1, j}}{2 \Delta x}
\end{gathered}
$$

and

$$
\frac{\partial t}{\partial y}=\frac{t_{i, j+1}-t_{i, j-1}}{2 \Delta y}
$$

where $x$ is the longitudinal coordinate, $y$ is the latitudinal coordinate, and $t_{i, j}$ is the elevation at grid point $i, j$.

\section{GRAVITY ANOMALY MAPS}

\section{Free-Air and Bouguer Gravity Anomalies}

The following general discussion is intended to give the reader a sense of significance of the various types of gravity anomalies. It leaves out many technical details of the gravity reduction process. For a more complete discussion of these points, the reader is referred to Lambert (1930), Swick (1942), Dobrin (1976), and Nettleton (1976).

Measurements of gravity are normally compared with the values that would theoretically be obtained if the measurements were made on an idealized surface (the reference ellipsoid) approximated by sea level. If only the latitude and the vertical distance of the gravity observation above sea level are taken into account, the difference between observed and theoretical gravity is known as the free-air anomaly; if the mass between the point of observation and 
sea level is also taken into account, then the difference is known as the Bouguer anomaly. To a first approximation the topographic mass above sea level can be regarded as a simple slab, or shell, but when irregularities on the upper surface of the slab (topography above and below the gravity station) are considered in the reduction, the resulting anomaly is designated the complete Bouguer anomaly, the standard anomaly for comparison with geologic features.

Free-air anomaly maps therefore reflect the vertical component of attraction of topographic masses above sea level as well as of anomalous masses below sea level. Bouguer anomaly maps, on the other hand, have had the effects of topographic mass removed down to sea level (at least to a first approximation). For this reason, Bouguer gravity maps present a clearer picture of the distribution of subsurface masses, and commonly display geologic features more clearly than free-air anomaly maps.

The free-air and complete Bouguer anomaly data shown in figures 2.7 and 2.8, respectively, represent subsets of gravity data compiled for the Basin and Range province by Hildenbrand and Kucks (1982), who discussed data reduction and gravity station locations in more detail. All gravity values are adjusted to conform to the International Gravity Standardization Net of 1971 (Morelli and others, 1974). Bouguer gravity anomaly values were computed using the 1967 gravity formula (International Association of Geodesy, $1967)$ and a Bouguer reduction density of $2.67 \mathrm{~g} / \mathrm{cm}^{3}$. Gravity stations have been terrain corrected for a distance of $0.895 \mathrm{~km}$ to $166.7 \mathrm{~km}$ from the station, using a computer program by Plouff (1977).

The free-air, Bouguer, and isostatic gravity data sets were gridded at a spacing of $4 \mathrm{~km}$ using a minimum curvature technique.

\section{Separating the Regional and Residual Gravity Anomaly}

A Bouguer gravity anomaly map exhibits the effects of source bodies of various shapes, dimensions, and burial depths. In any region, the gravity field usually reflects the superposition of the overlapping gravitational effects of many bodies whose individual gravity anomalies may be difficult to separate. The terms "residual" and "regional" are somewhat arbitrary, depending upon the map scale and source bodies of interest, but are commonly used to make a distinction between anomalies arising from local, nearsurface masses and those arising from larger and usually deeper features, respectively. There are many methods for preparing regional and residual maps (Grant, 1972). We have chosen a general wavelength (or frequency) filtering method to obtain a separation of long-wavelength anomalies (regional), typically associated with deep-crustal or subcrustal features, from short-wavelength anomalies (residual) that are associated with shallow features. The separation is not complete, however, and in particular, some long-wavelength anomalies can overlie broad, shallow features. The shortwavelength anomalies on the residual maps emphasize the contributions of shallow sources, but in many cases the anomaly amplitudes are distorted by the removal of the long wavelengths (Kane and Godson, 1985).

The gridded data were transformed to the wave number domain using the fast Fourier transform and then were lowpass filtered (Hildenbrand, 1983). The low-pass filter was a simple rectangular window (passing long wavelengths), modified so that the gain of the filter drops from one to zero along a ramp centered at the cut-off wavelength. The ramp was located between 100 and $150 \mathrm{~km}$; the cutoff wavelength was $125 \mathrm{~km}$. The regional (low-pass) field (fig. 2.9) was calculated by taking the inverse Fourier transform of the product of the low-pass filter and the Fourier-transformed Bouguer gravity field. The residual field (fig. 2.10) was calculated by subtracting the computed regional field from the unfiltered gravity field.

The effectiveness of the wavelength filtering process in calculating regional and residual gravity fields is partly a function of the relation of the cut-off wavelength of the filter and the maximum depth of sources. The residual gravity-anomaly map (fig. 2.10), composed of wavelengths of $125 \mathrm{~km}$ and less, exhibits anomalies which probably are associated primarily with sources within the crust; the effects of broad, shallow sources, however, are not present on this map. Conversely, the complementary low-pass map composed of wavelengths of $125 \mathrm{~km}$ and greater (fig. 2.9) generally represents the effects of deeper sources, such as the shape of the crust-mantle boundary and anomalous masses in the mantle and middle and lower crust, although the contributions of any broad, shallow masses are also included.

\section{Isostatic Residual Gravity Map}

In areas of mountainous terrain, perhaps the most useful gravity map for identifying and interpreting geologic structures in the upper crust is the isostatic residual gravity map (fig. 2.11). This map is similar to the residual gravity anomaly map (fig. 2.10), but has the advantage of being based on a physical model of the crustal structure. Deviations from the model should appear as anomalies in the residual field, and changes in the model can be made so as to fit the observed field. The gravity anomalies shown on figure 2.11 reflect lateral variations in subsurface density, primarily in the middle and upper crust.

It is known from empirical evidence that isostatic equilibrium occurs to a high degree throughout most of the world (Heiskanen and Vening Meinesz, 1958, chapter 7) and particularly well in the southwestern United States (Eaton and others, 1978; Oliver, 1980; Saltus, 1982; Oliver and others, 1982). A comparison of the terrain and Bouguer gravity maps of the southern Great Basin (figs. 2.5 and 2.8, respectively) shows a marked correlation between the higher topography to the north and the lower Bouguer gravity 
values. Most of this regional gravity correlation with topography has been removed on the isostatic residual map (fig. 2.11) making it possible to readily see the relations of local gravity anomalies with major faults and seismicity.

The crustal model used to generate the isostatic residual gravity map assumes perfect Airy isostasy, that is, that high topography is supported by deep-seated mass deficiencies in the form of low-density "mountain roots" of crustal material protruding into a denser upper mantle. The parameters of the model are the density of the high topography $(\rho)$, the contrast in densities between the upper mantle and the lower crust that displaces it $(W \rho)$, and the normal "sea level" thickness of the Earth's crust $(t)$. The values of the parameters used to produce figure 2.11 are $\rho=2.67 \mathrm{~g} / \mathrm{cm}^{3}$, $W \rho=0.4 \mathrm{~g} / \mathrm{cm}^{3}$, and $t=25 \mathrm{~km}$. The $2.67 \mathrm{~g} / \mathrm{cm}^{3}$ density is representative of felsic intrusive rocks and many of the Paleozoic rocks that make up many of the ranges in the southern Great Basin. The $0.4 \mathrm{~g} / \mathrm{cm}^{3}$ and $25 \mathrm{~km}$ values for $W \rho$ and $t$, respectively, are based on seismic-refraction data in California summarized by Jachens and Griscom (1985, p. 351), although current research suggests that the normal crustal thickness for the Basin and Range province may be somewhat lower (Oliver and Saltus, 1985). The effect of decreasing the parameter $t$ in the isostatic model is to raise the centroid of the mass deficiency under areas of high topography, which will increase algebraically the isostatic residual gravity values relative to areas of low topography.

Three-dimensional computation of the gravity effect of the crustal model at each of the approximately 30,000 regional gravity stations in the southern Great Basin was

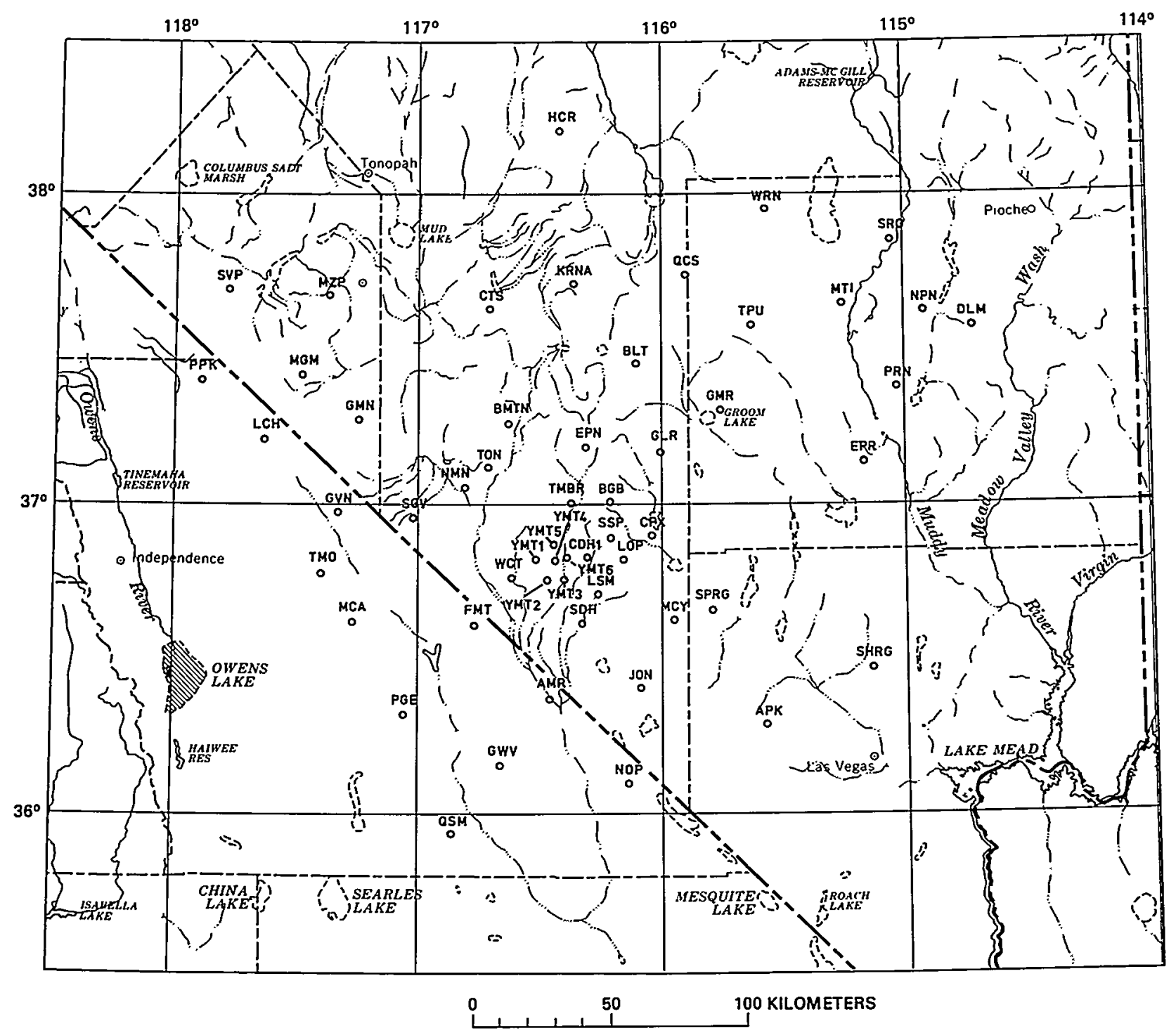

Figure 2.4. Southern Great Basin seismograph network. 
made using a FORTRAN program, "isocomp" (Jachens and Roberts, 1981). The 14,477 gravity stations in the Nevada Test Site were "thinned" to a minimum spacing of $0.4 \mathrm{~km}$ before operating on the data set. All existing gravity stations in that part of the southern Great Basin within California as compiled by Snyder and others (1982) were used to control the isostatic residual map (fig. 2.11).

\section{MAGNETIC ANOMALY MAPS}

\section{Total-Intensity Residual Magnetic Field}

The magnetization of crustal rocks is the vector resultant of magnetization induced in constituent minerals (chiefly magnetite) by the Earth's present dynamo field, plus the natural remanent magnetization of those minerals (Grant and West, 1965). Remanent or permanent magnetization acquired during the rock's history can have highly variable orientations. Crystalline rocks generally have sufficient magnetic minerals to cause variations in the Earth's magnetic field that can be mapped by aeromagnetic surveys. Sedimentary rocks, however, are generally much more weakly magnetized and have a small effect on the magnetic field; thus a magnetic anomaly map can be used to "see through" the sedimentaryrock cover and convey information on lithologic contrasts and structural trends related to crystalline basement (see Nettleton, 1971, for example).

The magnetic anomaly data shown in figure 2.12 are a subset of the aeromagnetic data of the Basin and Range province compiled by Hildenbrand and others (1983). The map provides a synoptic view of major anomalies. Reference geomagnetic fields, that approximate the Earth's main (core) field, have been subtracted from the recorded magnetic data. The resulting residual total intensity map exhibits contour patterns related primarily to crustal sources shallower than the Curie-point isotherm (the surface within the Earth beneath which temperatures are so great that rocks lose their magnetic properties).

The magnetic anomaly map has been compiled from digital data. Although these data were obtained from aeromagnetic surveys made at different times, spacings, and flight elevations, a consistent data set was constructed by analytical continuation of all data onto a common surface $3,810 \mathrm{~m}$ $(12,500 \mathrm{ft})$ above sea level. The residual magnetic anomaly data in figure 2.12 were projected to the Albers equal-area conic projection on a $2-\mathrm{km}$ grid. Hildenbrand and others (1983) gave more details regarding data reduction.

Accompanying the residual magnetic map are two filtered magnetic anomaly maps. Analysis by filtering in geophysical applications involves conversion of the data into a form that enhances particular anomaly characteristics, such as wavelength or trend. Two filtering operations have been used here: (1) a first-vertical-derivative operation to sharpen anomalies of shallow origin and small areal extent, and (2) a pseudo-gravity transformation followed by horizontal

8 Geologic and Hydrologic Investigations, Yucca Mountain, Nevada gradient analysis, to delimit lithologic or structural boundaries. New interpretative information may be obtained by studying these filtered anomaly maps (figs. 2.13 and 2.14), as discussed below, but they have important limitations and should be used with caution and only in a qualitative analysis.

\section{First-Vertical-Derivative Operation}

In areas of steep, broad magnetic gradients, lowamplitude and spatially restricted anomalies (related to nearsurface features) and other subtle features or trends tend to escape notice on the total-intensity anomaly map. This is especially the case for features having amplitudes less than $25 \mathrm{nT}$, which is the color contour interval of figure 2.12 . To resolve short-wavelength anomalies, a first-verticalderivative filter (Bhattacharyya, 1966) was applied to the magnetic data. The vertical derivative anomaly map shown in figure 2.13 thus enhances local features and reduces the effects of broad regional gradients.

\section{Pseudo-Gravity Gradient}

Cordell (1979) made use of horizontal gravity-gradient maxima to map graben-bounding faults. This technique, designed to delineate lithologic or structural boundaries, was later extended to the analysis of magnetic data through the use of the pseudo-gravity transformation (Cordell and Grauch, 1982).

Gravity and magnetic anomalies that reflect a common source of magnetization and density contrast are related to each other by Poisson's equation. Baranov (1957) suggested using Poisson's relation to calculate a pseudo-gravity anomaly map from magnetic data. The transformation of the magnetic field to the pseudo-gravity field requires no assumption regarding a common source of magnetization and density. The magnetization contrast related to a source is simply converted to a hypothetical density contrast to take advantage of analysis in terms of gravity. In our calculations, the ratio of the rocks' magnetization contrasts to their density contrasts was set to a constant value $\left(2.5 \times 10^{-2} \mathrm{SI} / \mathrm{g} / \mathrm{cm}^{3}\right)$, and induced magnetization in a uniform direction (inclination $64^{\circ} \mathrm{N}$., declination $16^{\circ} \mathrm{W}$.) was assumed.

Having made the pseudo-gravity transformation, the magnitude of the horizontal pseudo-gravity gradient $g^{\prime}$ is determined using the following equations:

$$
\begin{aligned}
\left|g^{\prime}(x, y)\right| & =\sqrt{\left(\frac{\partial g}{\partial x}\right)^{2}+\left(\frac{\partial g}{\partial y}\right)^{2}} \\
\frac{\partial g}{\partial x} & =\frac{g_{i+1, j}-g_{i-1, j}}{2 \Delta x}
\end{aligned}
$$

and

$$
\frac{\partial g}{\partial y}=\frac{g_{i, j+1}-g_{i, j-1}}{2 \Delta y}
$$


where $x$ is the longitudinal coordinate, $y$ is the latitudinal coordinate, and $g_{i, j}$ is the pseudo-gravity field defined at grid point $i, j$.

Pseudo-gravity gradient maxima occur immediately over steep or vertical boundaries separating contrasting magnetizations. On the pseudo-gravity gradient map (fig. 2.14), lines drawn along ridges of high horizontal gradient magnitudes correspond to these boundaries. If the boundaries have shallow dips, if remanent magnetization is strong, or if contributions from adjacent sources are significant, the maximum gradient will be shifted a certain distance from the uppermost part of the boundary.

\section{REFERENCES CITED}

Bailey, E.H., ed., 1966, Geology of northern California: California Division of Mines and Geology Bulletin 190, 508 p.

Baranov, V., 1957, A new method for interpretation of aeromagnetic maps-Pseudo-gravimetric anomalies: Geophysics, v. 22 , no. 2 , p. 359-383.

Bhattacharyya, B.K., 1966, A method for computing the total magnetization vector and the dimensions of a rectangular blockshaped body from magnetic anomalies: Geophysics, v. 31, no. 1 , p. 74-96.

Carr, W.J., 1984, Regional structural setting of Yucca Mountain, southwestern Nevada, and late Cenozoic rates of tectonic activity in part of the southwestern Great Basin, Nevada and California: U.S. Geological Survey Open-File Report 84-854, 109 p.

Cordell, Lindrith, 1979, Gravimetric expression of graben faulting in Santa Fe County and the Espanola basin, New Mexico: New Mexico Geological Guidebook, 30th Field Conference, Santa Fe County, p. 59-64.

Cordell, Lindrith, and Grauch, V.J.S., 1982, Mapping basement magnetization zones from aeromagnetic data in the San Juan Basin, New Mexico, in Society of Exploration Geophysicists, Abstracts with Program, 1982, Annual Meeting: p. 246-247.

Dobrin, M.B., 1976, Introduction to geophysical prospecting (3d ed.): New York, McGraw-Hill, 630 p.

Eaton, G.P., Wahl, R.R., Prostka, H.J., Mabey, D.R., and Kleinkopf, M.D., 1978, Regional gravity and tectonic patterns: Their relation to late Cenozoic epeirogeny and lateral spreading in the western Cordillera, in Smith, R.B., and Eaton, G.P., eds., Cenozoic tectonics and regional geophysics of the Western Cordillera: Geological Society of America Memoir 152, p. 51-92.

Godson, R.H., 1981, Digital terrain map of the United States: U.S. Geological Survey Miscellaneous Investigations Map I-1318, scale 1:7,500,000.

Grant, F.S., 1972, Review of data processing and interpretation methods in gravity and magnetics, 1964-1971: Geophysics, v. 37, no. 4, p. 647-661.

Grant, F.S., and West, G.F., 1965, Interpretation theory in applied geophysics: New York, McGraw-Hill, 583 p.

Heiskanen, W.A., and Vening Meinesz, F.A., 1958, The earth and its gravity field: New York, McGraw-Hill, 467 p.

Hildenbrand, T.G., 1983, FFTFIL: A filtering program based on two-dimensional Fourier analysis: U.S. Geological Survey
Open-File Report 83-237, 60 p.

Hildenbrand, T.G., and Kucks, R.P., 1982, A description of colored gravity maps of the Basin and Range Province, southwestern U.S.: U.S. Geological Survey Open-File Report 82-500, 8 p.

Hildenbrand, T.G., Kucks, R.P., and Sweeney, R.E., 1983, Colored digital magnetic anomaly map of the Basin and Range Province: U.S. Geological Survey Open-File Report 83-189.

International Association of Geodesy, 1967, Geodetic Reference System 1967: International Association of Geodesy Special Publication no. 3, $116 \mathrm{p}$.

Jachens, R.C., and Griscom, Andrew, 1985, An isostatic residual gravity map of California-A residual map for interpretation of anomalies from intracrustal sources, in Hinze, W.J., ed., The utility of regional gravity and magnetic anomaly maps: Tulsa, Okla., Society of Exploration Geophysicists, p. 347360.

Jachens, R.C., and Roberts, C.W., 1981, Documentation of a FORTRAN program, 'isocomp', for computing isostatic residual gravity: U.S. Geological Survey Open-File Report $81-574,26 \mathrm{p}$.

Kane, M.F., and Godson, R.H., 1985, Features of a pair of long wavelength $(>250 \mathrm{~km})$ and short wavelength $(<250 \mathrm{~km})$ Bouguer gravity maps of the United States, in Hinze, W.J., ed., The utility of regional gravity and magnetic anomaly maps: Tulsa, Okla., Society of Exploration Geophysicists, p. 46-61.

King, P.B., and Beikman, H.M., 1974, Geologic map of the United States (exclusive of Alaska and Hawaii): U.S. Geological Survey, scale 1:2,500,000.

Lambert, W.D., 1930, The reduction of observed values of gravity to sea level: Bulletin Geodesique, no. 26, April-June, p. 107-181.

Morelli, Carlo, Gantav, C., Honkasala, Tauno, McConnel, R.K., Tanner, J.G., Szabo, Bela, Uotila, U.A., and Walen, G.T., 1974, The International Gravity Standardization Net 1971 (IGSN-1971): Paris, Bureau Central de L'Association Internationale de Geodesie, Special Publication 4, 194 p.

Nakata, J.K., Wentworth, C.M., and Machette, M.N., 1982, Quaternary fault map of the Basin and Range and Rio Grande Rift Provinces, Western United States: U.S. Geological Survey Open-File Report 82-579, scale 1:2,500,000.

Nettleton, L.L., 1971, Elementary gravity and magnetics for geologists and seismologists: Society of Exploration Geophysicists Monograph No. 1, 121 p.

1976, Gravity and magnetics in oil prospecting: New York, McGraw-Hill, 464 p.

Oliver, H.W., ed., 1980, Interpretation of the gravity map of California and its continental margin: California Division of Mines and Geology Bulletin 205, 52 p.

Oliver, H.W., and Saltus, R.W., 1985, Variations in new isostaticgravity maps of the Southwestern United States based in nine models (expanded abstract), in Kahle, H.G., and Bartholomew, J., eds., Workshop Report of the International Association of Geodesy, SSG, 5.97, on "Density distribution of the lithosphere, static and dynamic models"' held May 28-31, 1985, at ETH University, Zurich, Switzerland: Zurich, ETH Institute for Geodesy and Photogrammetry Report No. 102, p. 27-28.

Oliver, H.W., Saltus, R.W., Mabey, D.R., and Hildenbrand, T.G., 1982, Comparison of Bouguer anomalies and isostatic residual gravity maps of the southwestern Cordillera (expanded abstract): Society of Exploration Geophysicists, 52nd Annual Meeting, Dallas, Technical Program Abstracts, p. 306-308. 
Plouff, Donald, 1977, Preliminary documentation for a FORTRAN program to compute gravity terrain corrections based on topography digitized on a geographic grid: U.S. Geological Survey Open-File Report 77-534, 45 p.

Rogers, A.M., Harmsen, S.C., Carr, W.J., and Spence, W., 1983, Southern Great Basin seismological data report for 1981 and preliminary data analysis: U.S. Geological Survey Open-File Report 83-669, 240 p.

Rogers, A.M., Harmsen, S.C., Herrmann, R.B., and Meremonte, M.E., 1987, A study of ground-motion attenuation in the southern Great Basin, California-Nevada, using several techniques for estimates of $Q_{s}, \log A_{0}$, and Coda $Q$ : Journal of Geophysical Research, v. 92, p. 3527-3540.

Rogers, A.M., Harmsen, S.C., and Meremonte, M., 1987, Evaluation of the seismicity of the Southern Great Basin and its relationship to the tectonic framework of the region: U.S. Geological Survey Open-File Report 87-408.
Saltus, R.W., 1982, A description of Bouguer anomaly and isostatic residual colored gravity maps of the southwestern Cordillera: U.S. Geological Survey Open-File Report 82-839.

Snyder, D.B., Roberts, C.W., Saltus, R.W., and Sikora, R.F., 1982, Description of magnetic tape containing the principal facts of 64,026 gravity stations in the state of California: U.S. Geological Survey Report, 34 p.; available from the National Technical Information Service, Springfield, VA, NTIS-PB82168279.

Swadley, W C, Hoover, D.L., and Rosholt, J.N., 1984, Preliminary report on late Cenozoic faulting and stratigraphy in the vicinity of Yucca Mountain, Nye County, Nevada: U.S. Geological Survey Open-File Report 84-788, 42 p.

Swick, C.H., 1942, Pendulum gravity measurements and isostatic reductions: U.S. Coast and Geodetic Survey Special Publication $232,82 \mathrm{p}$. 
FIGURES 2.5-2.14

$\overline{\underline{ }}$ 

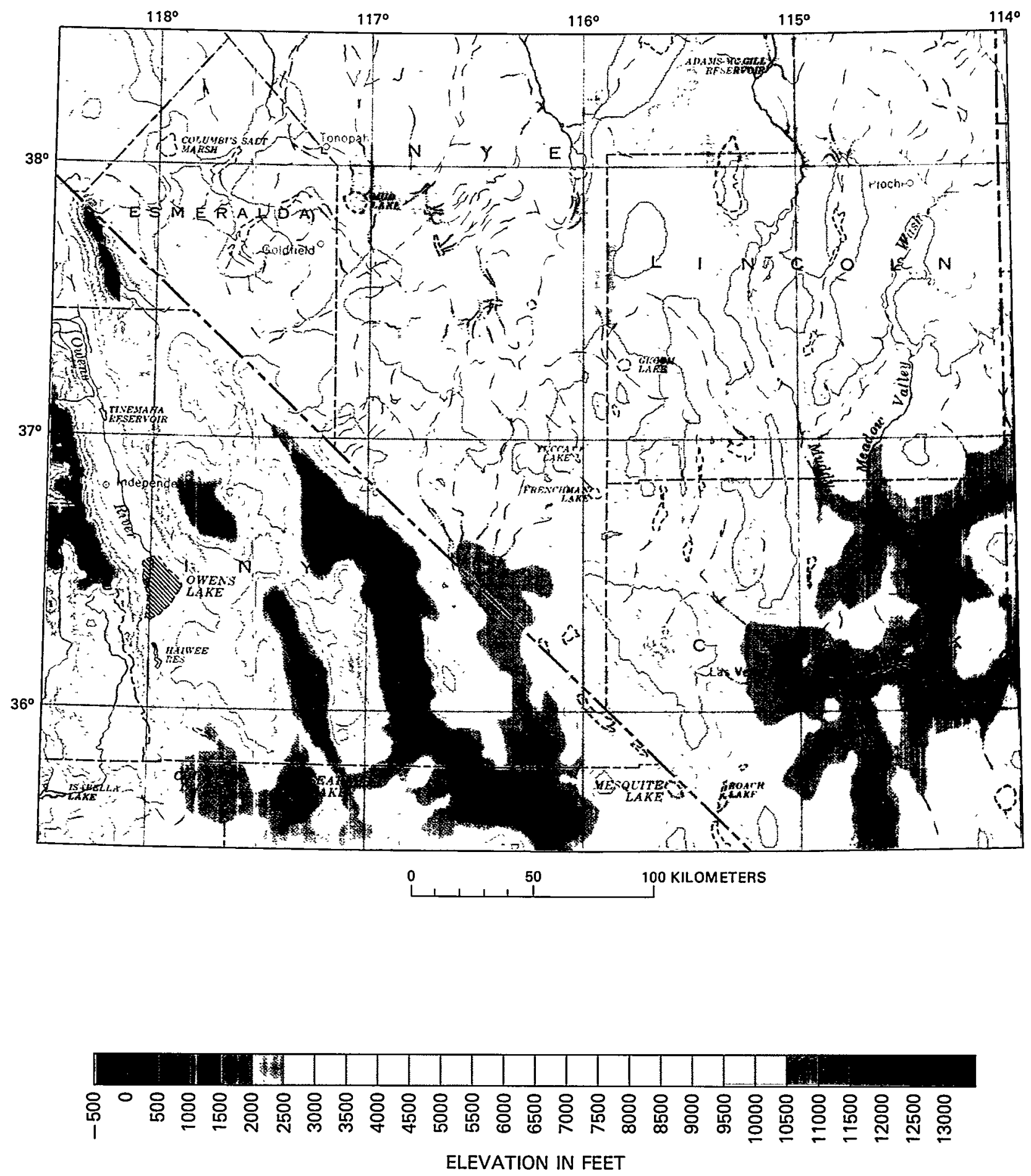

Figure 2.5. Terrain map of southern Great Basin. 


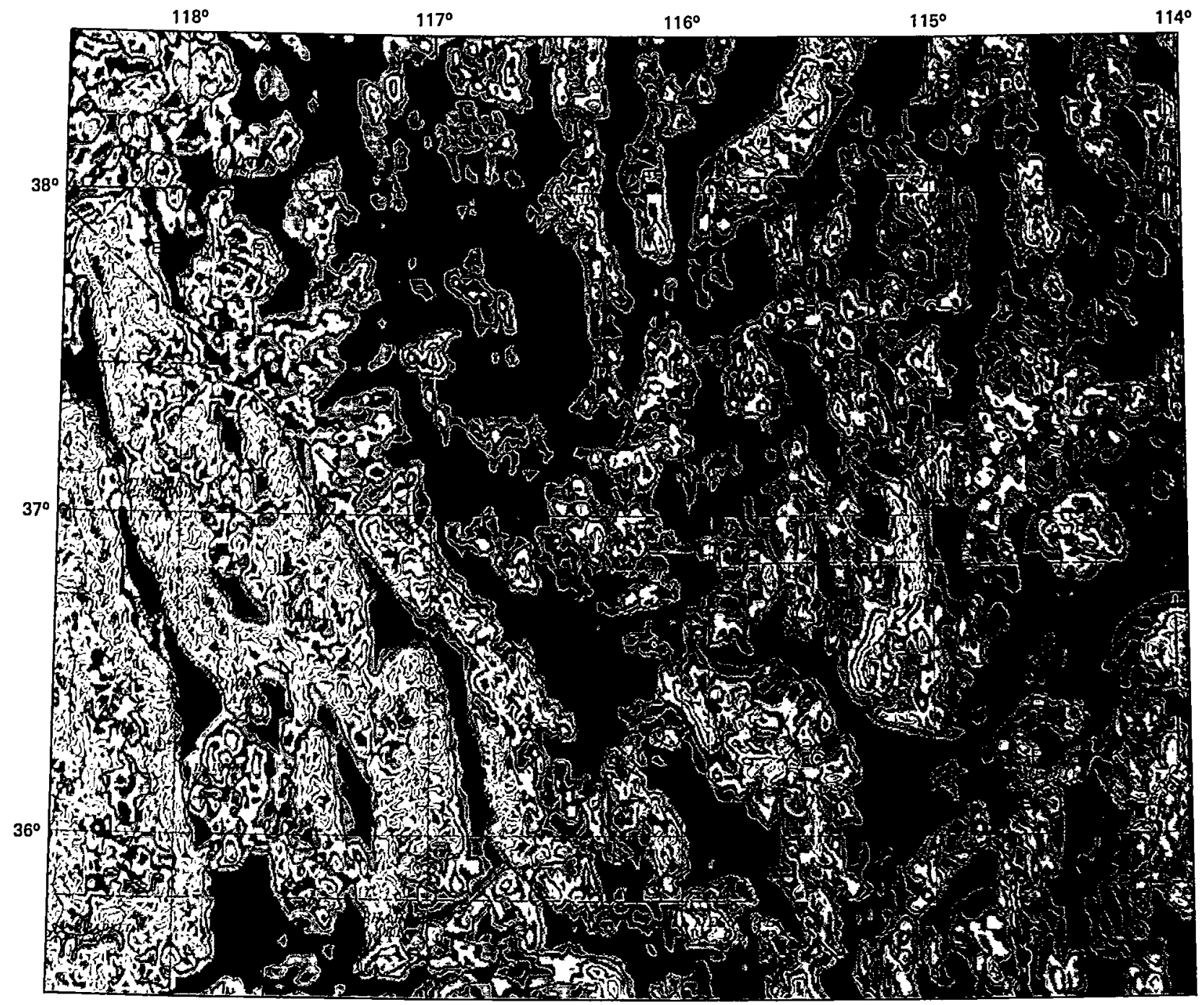

.

50

100 KILOMETERS

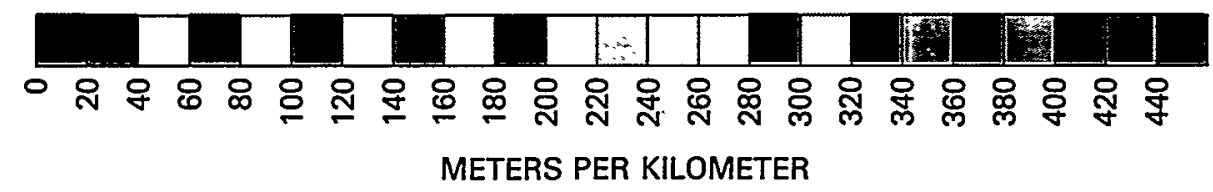

Figure 2.6. Terrain-slope map of southern Great Basin. 

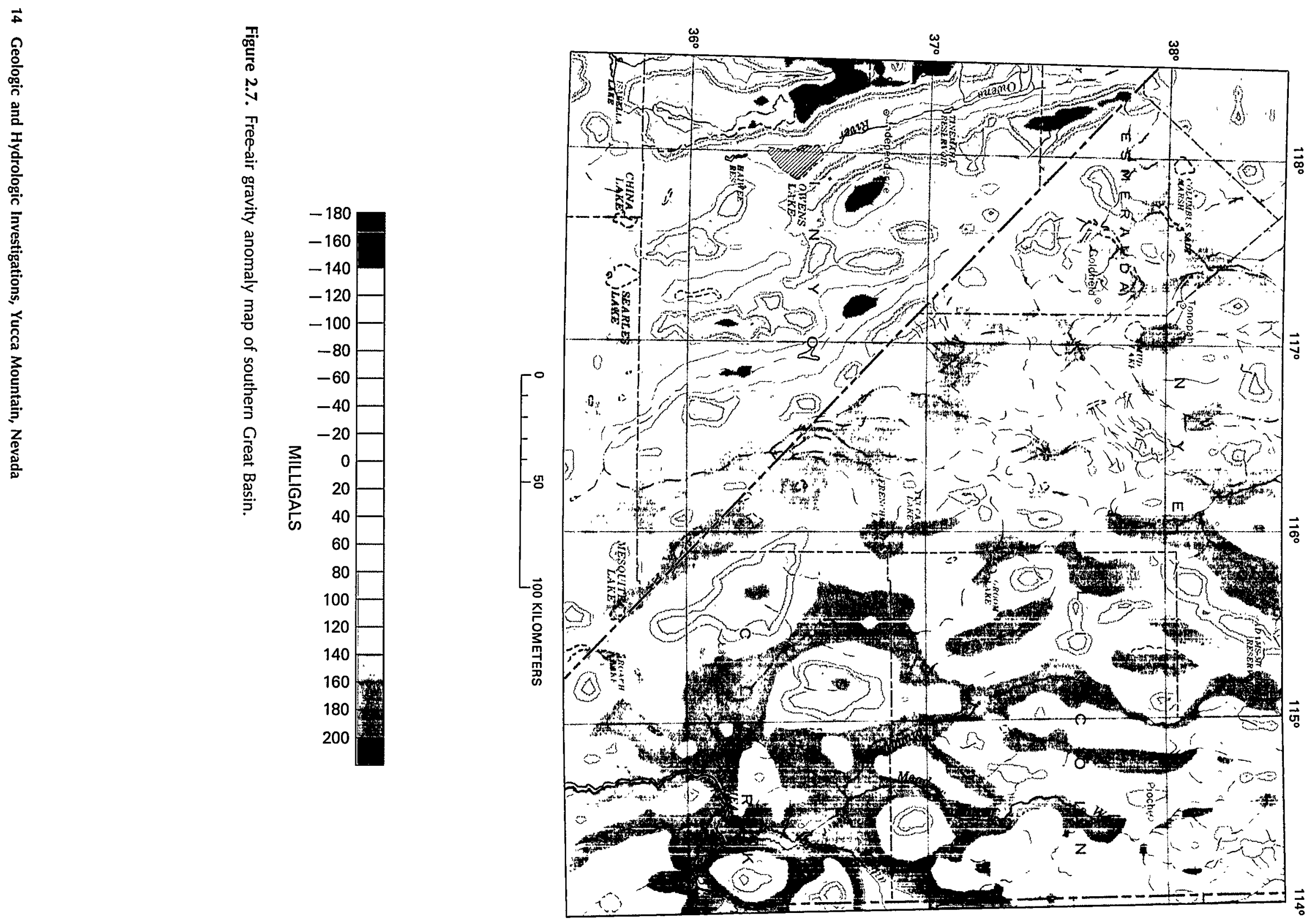

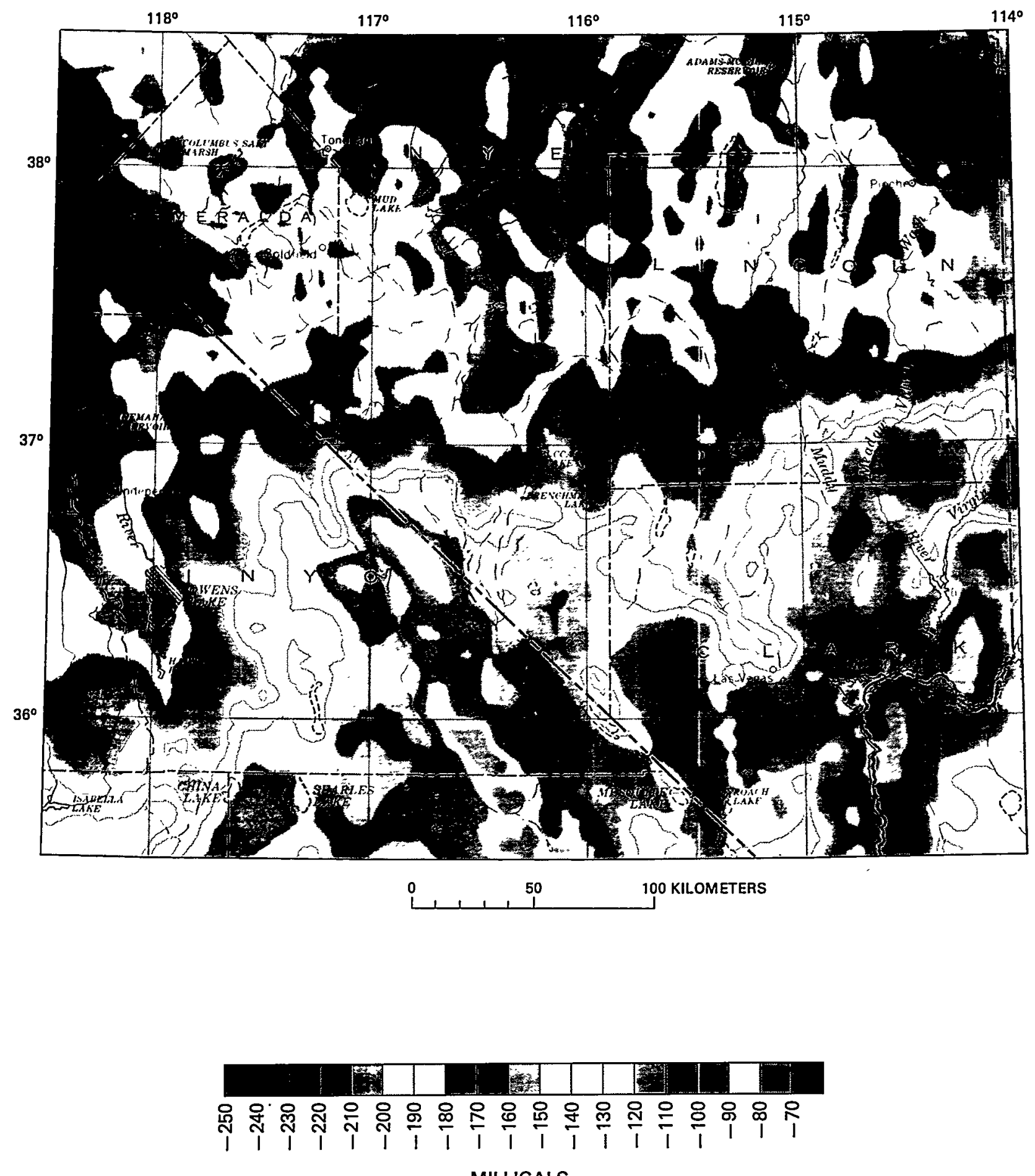

MILLIGALS

Figure 2.8. Complete Bouguer gravity-anomaly map of southern Great Basin. 

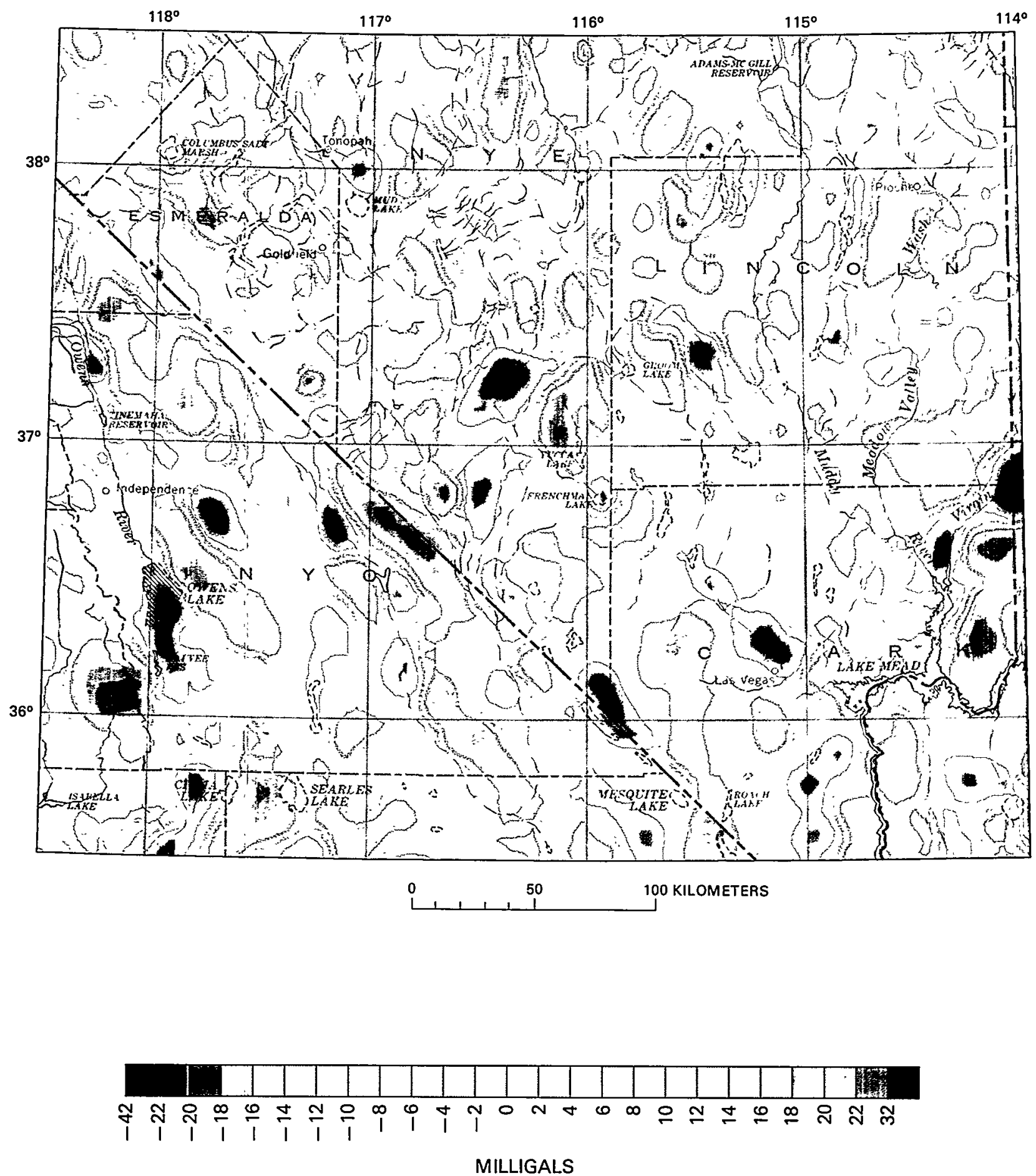

Figure 2.9. Regional gravity-anomaly map (wavelengths longer than $125 \mathrm{~km}$ ) of southern Great Basin. 

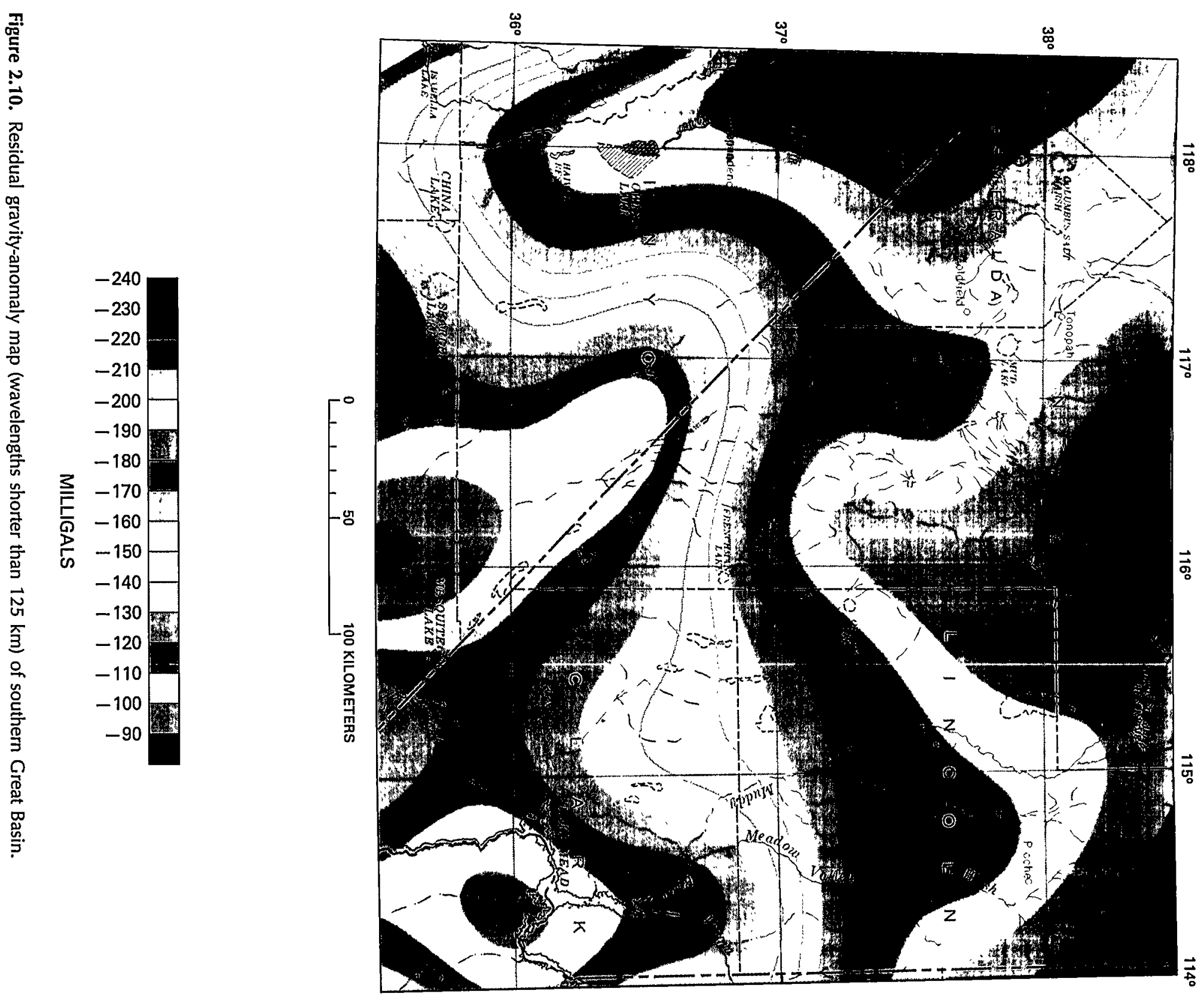

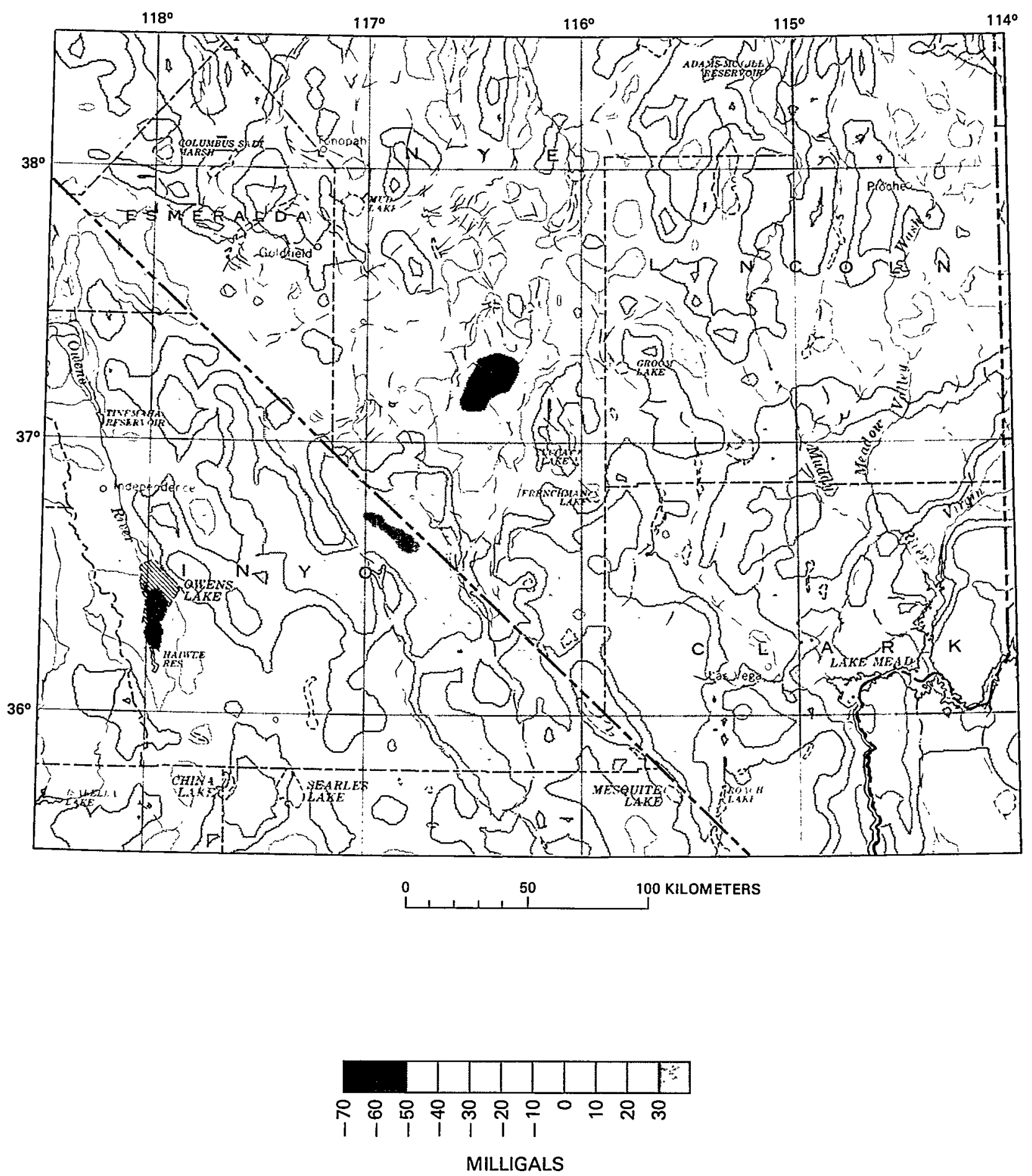

Figure 2.11. Isostatic residual gravity map of southern Great Basin. 


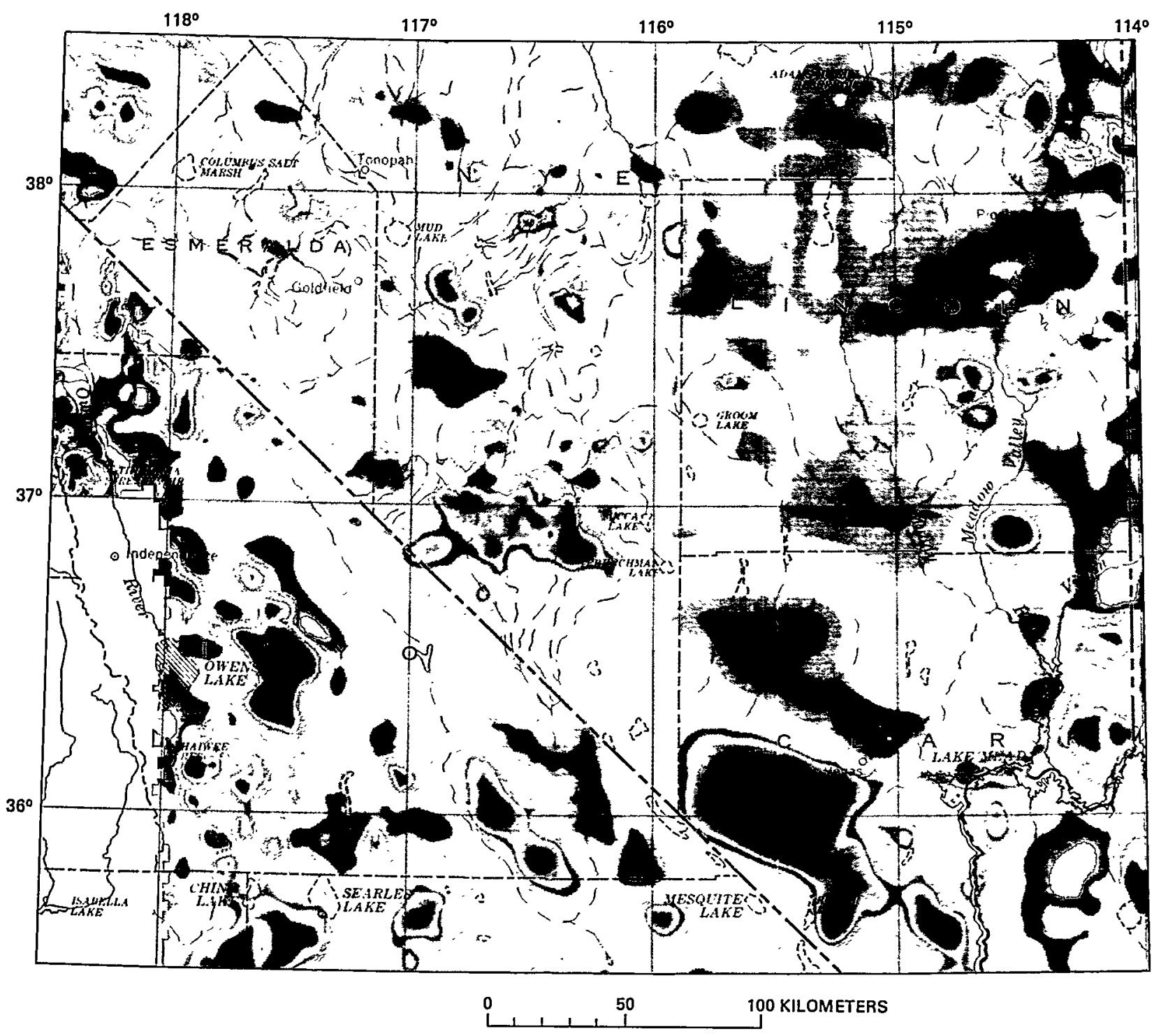

\section{4}

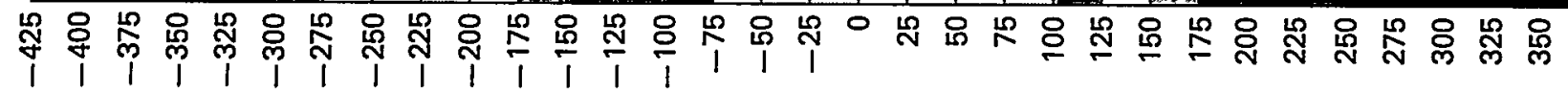

\section{GAMMAS}

Figure 2.12. Residual total magnetic anomaly map of southern Great Basin. 

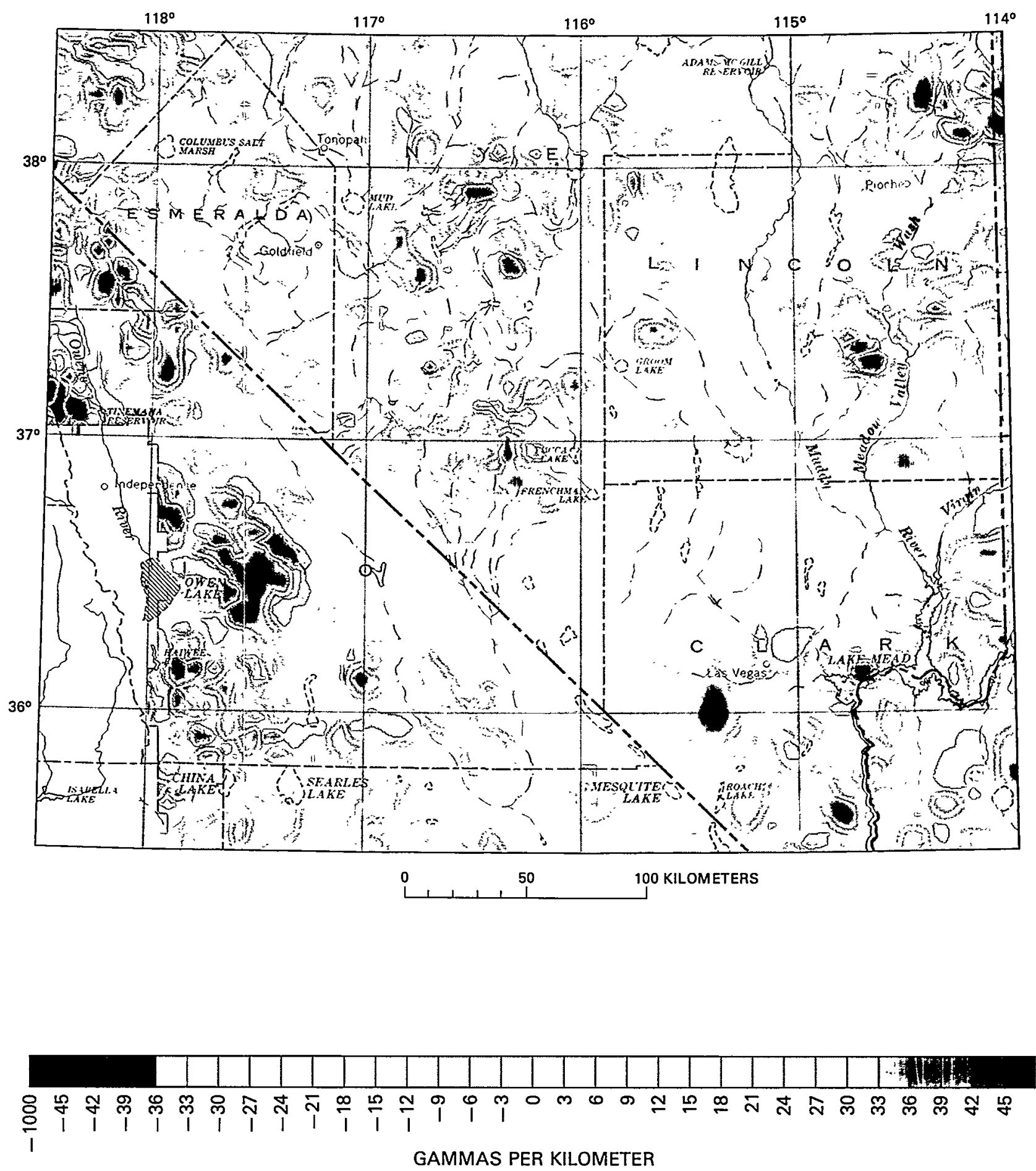

Figure 2.13. First vertical derivative of magnetic field of southern Great Basin. 

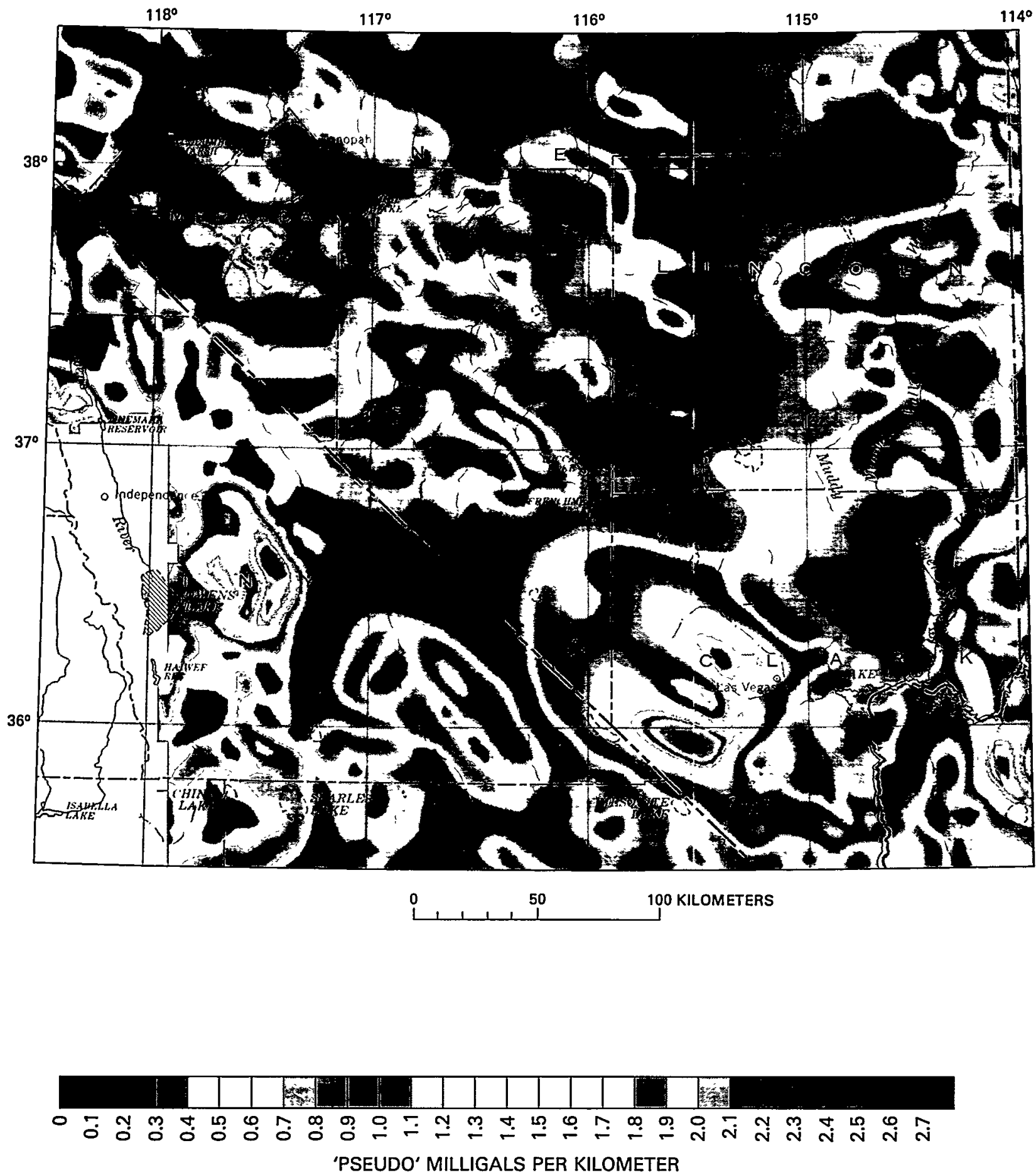

Figure 2.14. Magnitude of horizontal gradient of pseudo-gravity field of southern Great Basin. 



\title{
3. Preliminary Interpretation of Seismic-Refraction and Gravity Studies West of Yucca Mountain, Nevada and California
}

\author{
By Hans D. Ackermann, Walter D. Mooney, David B. Snyder, \\ and Vickie D. Sutton
}

\section{CONTENTS}

Abstract 23

Introduction 23

Acknowledgments 24

Geologic setting 24

Data collection 25

Data analysis 25

Results 26

Interpretation of the Crater Flat and Beatty velocity sections 27

Velocity, density, and depth relations $\mathbf{3 0}$

Possible relation of geophysical data to detachment faults $\mathbf{3 2}$

Conclusions 33

References cited 33

\section{Abstract}

Crustal velocity sections based on two seismic-refraction profiles are presented for the area west of Yucca Mountain, Nye County, Nevada. The north-south Crater Flat profile nearly parallels the west side of Yucca Mountain and extends northward from the Amargosa Desert valley to the northeast corner of Crater Flat. The Beatty profile extends westward from northern Crater Flat past Beatty and the Bullfrog Hills to Death Valley.

The Crater Flat profile is interpreted in terms of six velocity layers ranging from 1.5 to $6.1 \mathrm{~km} / \mathrm{s}$. The interpreted prevolcanic surface has a relief of over $2,000 \mathrm{~m}$, ranging from approximately $2.2 \mathrm{~km}$ below sea level (total depth below surface of $3.2 \mathrm{~km}$ ) in the center of Crater Flat to approximately sea level (total depth of $1.3 \mathrm{~km}$ ) beneath southern Yucca Mountain.

Interpretation of the Beatty profile reveals an escarpment near the northeast edge of Bare Mountain, where Paleozoic rocks are probably down-faulted $2,600 \mathrm{~m}$ into a volcano-tectonic depression in Crater Flat.

The seismic profiles and inferred density-velocity relations have been incorporated into an east-west gravity model from Death Valley to Crater Flat, corresponding to the Beatty seismic profile. An important feature of this model is the inferred continuity of a layer with a model density of $2.74 \mathrm{~g} / \mathrm{cm}^{3}$ (corresponding to a seismic velocity of $6.3 \mathrm{~km} / \mathrm{s}$ ) from the Grapevine Mountains to Bare Mountain. This layer is interpreted as the lower plate of a regional decollement or detachment fault.

\section{INTRODUCTION}

This report presents the velocity structure derived from two crustal seismic-refraction profiles recorded west of Yucca Mountain in 1983. These profiles, which we have named the Beatty and Crater Flat profiles (fig. 3.1), represent part of a continuing program of seismic investigations in the region of Yucca Mountain.

Previous seismic investigations in the region consisted of three reconnaissance refraction spreads east of Yucca Mountain (Pankratz, 1982), which had a maximum penetration depth of about $600 \mathrm{~m}$; a reconnaissance "highresolution" reflection survey by the Colorado School of Mines (Barry, 1980); two industry reflection surveys along the east flank of Yucca Mountain (McGovern, 1983); an engineering refraction survey (unpublished) by H.D. Ackermann along the east edge of Yucca Mountain; and an unreversed reconnaissance crustal refraction profile (Hoffman and Mooney, 1983), which crossed Yucca Mountain at the proposed repository site. With the exception of the Hoffman and Mooney (1983) profile, none of the surveys produced results that could be interpreted in terms of stratigraphic relations at Yucca Mountain. The three reflection surveys failed to record a single coherent reflection event, attesting to the high degree of variability and poor sound transmission properties of the shallower rocks in the area. These negative results were further complicated by the shallow refraction studies, which demonstrated not only the inherent difficulty of producing and recording coherent sound signals in the volcanic rocks, but also their high degree of lateral variablity.

On the other hand, good upper-crustal refraction returns were obtained from the reconnaissance survey by Hoffman and Mooney (1983) and from the work leading to this report. These results formed the basis for additional deep refraction studies in the Yucca Mountain region conducted in 1985, which are not reported here.

In their interpretation of the unreversed profile, Hoffman and Mooney (1983) relied upon inferred relations 
between seismic velocities and rock densities derived from the gravity modeling (Snyder and Carr, 1982) to compute depths to the prevolcanic surface beneath Crater Flat. The detailed gravity models have also provided an excellent framework for the interpretation and discussion of the present refraction results.

An objective of the present survey was to improve on the earlier depth estimates by using reversed refraction profiles. The results also suggest some revisions of the gravity models.

\section{Acknowledgments}

We wish to thank our U.S.G.S. colleagues for their valuable critical comments on this paper. The data analyzed in this paper were collected by the authors and $\mathrm{G}$. Bloomberg, M. Burns, B. Colburn, T. Conway, E. Criley, B. Echols, L. Greene, R. Kaderabek, P. Meador, J. Murphy, and L. Pace. We thank all of them for their diligent field efforts.

\section{GEOLOGIC SETTING}

A brief discussion of the geologic framework pertinent to this report follows. A more thorough review is provided by Snyder and Carr (1984) and Carr (1984).

The study area lies within the southern part of the Great Basin, a large structural and physiographic section of the Basin and Range province. Whereas much of the Great Basin is characterized by linear, fault-bounded ranges separated by elongate deep structural basins of late Cenozoic age, most of the area considered here, between Death Valley and Yucca Mountain, does not contain well-developed typical basinrange structure. Instead the area is one of diverse structural style, trends, and topography, called the Walker Lane belt or Walker belt by some authors (Stewart, 1980; Carr, 1984).

The oldest rocks exposed in the region are partially metamorphosed sedimentary rocks of Proterozoic age, mainly on Bare Mountain and in the Funeral Mountains (fig. 3.1). These rocks, which are mostly quartzite and other mildly metamorphosed clastic rocks, are overlain by a very

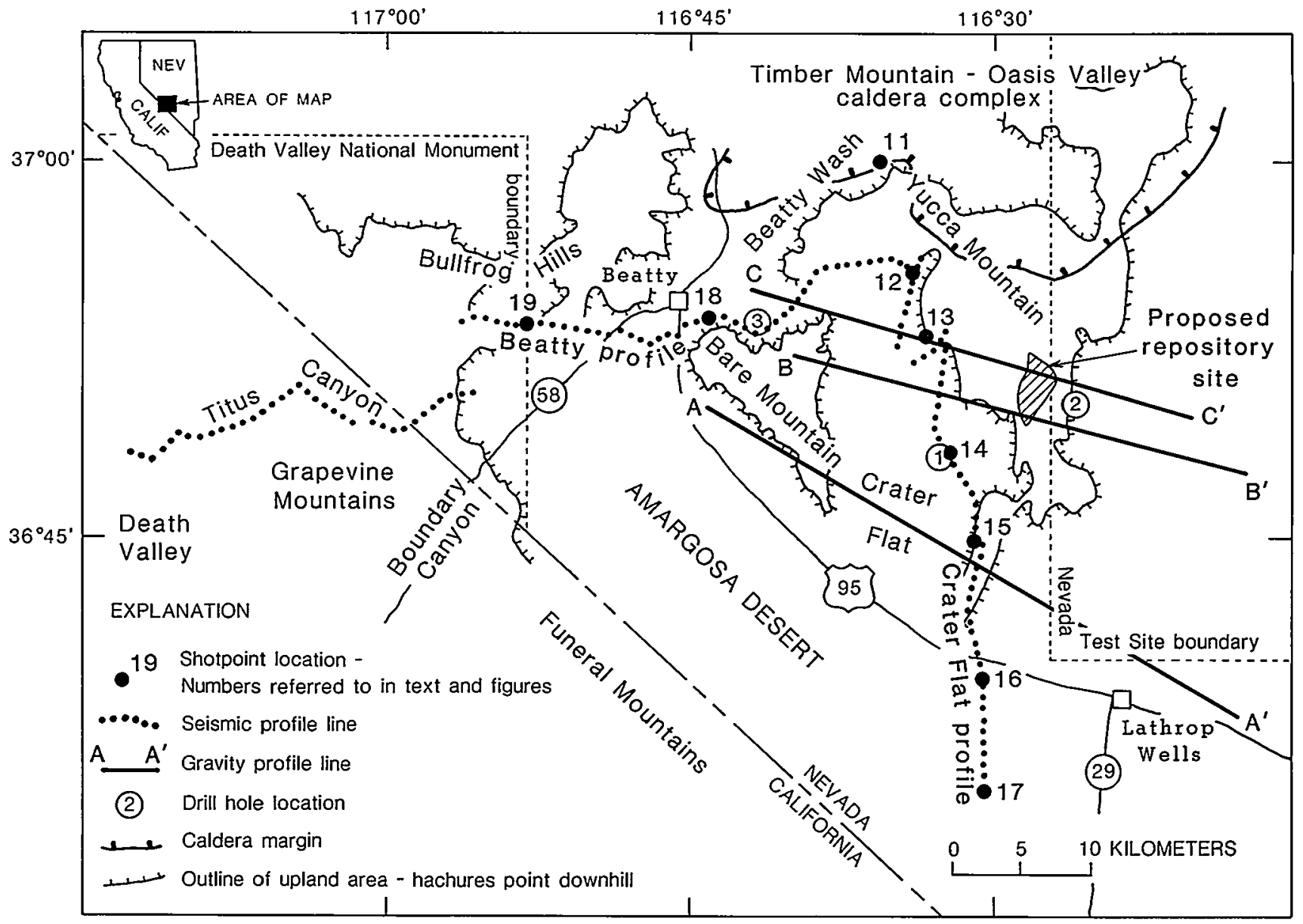

Figure 3.1. Map of study area showing locations of seismic and gravity profiles (Snyder and Carr, 1982) and shotpoint and drill hole locations. Drill hole 1, USW VH-1; 2, UE-25P1; and 3, US Borax. 
thick section of Paleozoic, largely carbonate sedimentary rocks. In some areas, as in the northern part of Bare Mountain, these carbonate rocks are thrust over middle Paleozoic clastic rocks (Eleana Formation). Granite of Mesozoic age crops out at the northwest corner of Bare Mountain, and similar granites may be present in the subsurface in an eastwest belt from the Grapevine Mountains to east of Yucca Mountain (Carr, 1984, fig. 13).

Locally thick Tertiary rocks lie unconformably above the Paleozoic rocks in most of the area. Oligocene rocks in the Grapevine Mountains consist mainly of conglomerate and other sedimentary rocks, as well as minor tuff. Most of the volcanic rocks of the Bullfrog Hills and north and east of Bare Mountain are tuff and subordinate lava flows of Miocene age. Yucca Mountain and Crater Flat contain thick (greater than 2,000 m) sections of welded tuff. The youngest volcanic rocks are scattered rhyolite and basalt lavas of late Miocene age and small basalt flows of Pliocene and Quaternary age in and near Crater Flat. Alluvium of Pliocene and Quaternary age is relatively thin (less than $500 \mathrm{~m}$ ) in most of the area.

Several Miocene calderas are present. Shotpoint 11 (fig. 3.1) is at the south edge of the large Timber MountainOasis Valley caldera complex (Byers and others, 1976). Another slightly older group of calderas, or a volcanotectonic depression, may be present beneath Crater Flat and possibly the northern part of Yucca Mountain (Carr and others, 1986; Carr, 1982).

The pre-Tertiary and Tertiary rocks are moderately faulted in most areas. North of Bare Mountain and to the west in the Bullfrog Hills, the structure in the volcanic rocks is dominated by complex northeast- and northwest-striking faults, many of which have had some strike-slip displacement and may be listric, that is, level off at depth. The middle and southern parts of Yucca Mountain are cut by westdipping, north-south-striking basin-range faults. The structure within Crater Flat may be controlled by largely buried caldera ring faults; the major fault on the east side of Bare Mountain is probably part of this system (Carr, 1982).

Of particular interest with respect to this report is the presence at Boundary Canyon in the Funeral Mountains (fig. 3.1) of a low-angle detachment fault (Giarmita and others, 1983). This structure separates metamorphosed lower plate, mostly Proterozoic rocks, from overlying relatively unmetamorphosed Paleozoic rocks. This structure probably continues northeastward into the Bullfrog Hills and possibly farther to the east.

\section{DATA COLLECTION}

Both profiles reported here were collected in April 1983. The Crater Flat profile (fig. 3.1) extends northward from the Amargosa Desert valley, obliquely across the southern tip of Yucca Mountain, along the east side of Crater Flat, and to a point near the northeast corner of Crater Flat.
Seven shotpoints, numbered 11 through 17 , were located at approximately 8-km intervals along this profile. Shotpoint 11 lay beyond the array of seismographs about $9 \mathrm{~km}$ north of shotpoint 12. Each shot consisted of approximately $900 \mathrm{~kg}$ of ammonium nitrate emplaced in 50-m drill holes. The 46-km-long profile length was designed to provide details of the crustal structure to a maximum depth at least as great as the prevolcanic rocks, estimated to be as much as $4 \pm 1$ $\mathrm{km}$ from gravity data.

The Beatty profile (fig. 3.1) extends west from shotpoint 12 of the Crater Flat profile, past the north edge of Bare Mountain to the Bullfrog Hills. Three shots with an average spacing of $14 \mathrm{~km}$ were fired along the profile. They are numbered 12,18 , and 19 , and had the same drill-hole depths and charge size as those on the Crater Flat profile. In addition, reconnaissance measurements were made by placing seismographs as far west as Death Valley along the Titus Canyon road. Thus, the portion of the seismic profile between the Bullfrog Hills and northern Crater Flat is reversed, but the part between the Bullfrog Hills and Death Valley is unreversed.

Data for each profile were recorded by 120 portable seismographs of recent design (Healy and others, 1982). These instruments are equipped with vertical-component seismometers having a natural frequency of $2 \mathrm{~Hz}$, and the data were recorded in frequency modulated format on cassette tapes. Analog tapes were digitized in the U.S. Geological Survey laboratory at Menlo Park, Calif., at a sampling rate of 200 samples per second.

The principal facts for these profiles (shotpoint and recorder locations, timing, instrumentation, and so forth) were reported by Sutton (1984).

\section{DATA ANALYSIS}

Many methods are available for processing seismicrefraction data; their theoretical bases are well described in a number of texts (see Grant and West, 1965; Telford and others, 1976). Some of these techniques involve essentially trial-and-error fitting of the observations by successive model calculations, a process that can be as tedious for the interpreter as it is arbitrary in the final result obtained. To avoid the inherent uncertainties of trial-and-error model fitting, these refraction profiles were recorded with field parameters satisfying the requirements of a method for the direct computer inversion of the data (Ackermann and others, 1982, 1983). The primary requirements are that there be close spatial sampling of the data and multiple shotpoints along the profile.

The complete seismic record sections obtained in this study were presented without analysis by Sutton (1984). For the present analysis, arrival times were picked from expanded record sections to improve timing accuracy. Samples of the data at this scale are shown in figure 3.2. Arrival times, complete traveltime curves, smoothed elevations, and surface 
velocities for all shots and recorders were entered into computer data files for use in final processing.

\section{RESULTS}

Complete analysis of refraction data consists of two stages, data processing and geologic interpretation. Processing is a problem of geometrical ray tracing, done with minimum regard to geology and resulting in velocity sections indicating layers having velocities that may vary laterally. The processed velocity sections for the Crater Flat and Beatty profiles, at 6.2 times vertical exaggeration and with no vertical exaggeration, are shown in figures 3.3 and 3.4. The upper boundary (or horizon) of each layer represents the calculated path (or portion of the path) of a critically refracted ray, and the varying layer velocities represent lateral changes in velocity along a particular ray path. Seismic horizons need not conform with geologic horizons. Instead, they represent minimum time paths, which can pass from one geologic regime into another, and hence can be represented on a processed velocity section only as a change in the velocity within a layer. A case in point is shown in figure 3.3 at the boundary between southern Yucca Mountain and Crater Flat. Here the velocity of the fifth layer changes from 4.8 to $5.4 \mathrm{~km} / \mathrm{s}$, which, from geologic interpretation, probably represents a lateral change from volcanic into prevolcanic rocks.

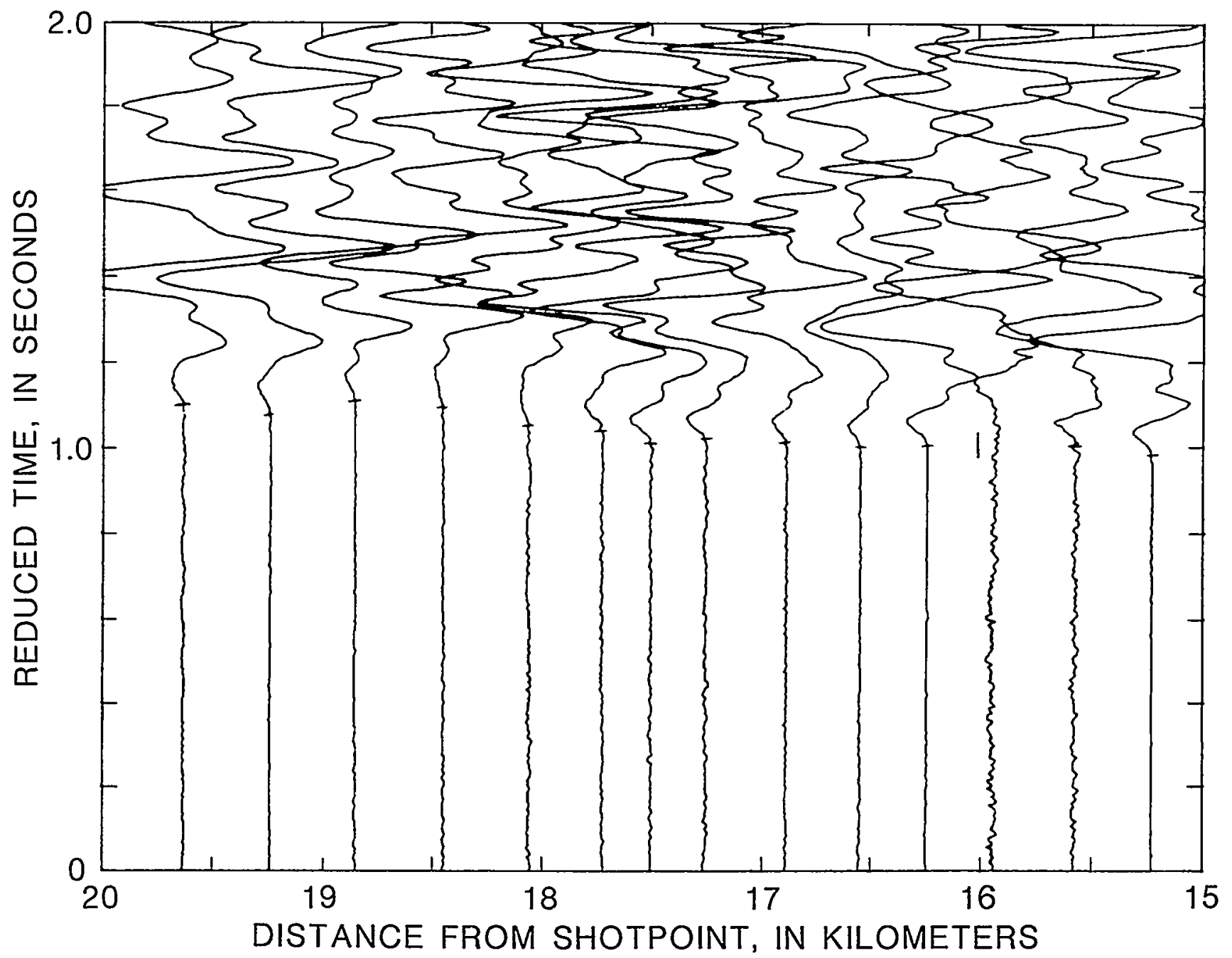

Figure 3.2. Seismic traces from shotpoint 17 on Crater Flat profile, plotted with reduced traveltime of $6.0 \mathrm{~km} / \mathrm{s}$. Small dashes on traces indicate first arrival picks. See figure 3.1 for location. 


\section{INTERPRETATION OF THE CRATER FLAT AND BEATTY VELOCITY SECTIONS}

The velocity sections (figs. 3.3 and 3.4) show horizons as discrete boundaries at which an abrupt increase in layer velocity occurs. However, analysis of velocity surveys in boreholes in the Yucca Mountain area show that, although abrupt changes in velocity do occur in the subsurface, the velocity functions are best described by smooth curves rather than discrete breaks. Furthermore, analysis of borehole densities in the Tertiary tuff sequence (Snyder and Carr, 1982, 1984) show a downward increase in density mainly related to closing of pore spaces rather than to primary density variations in the tuff. Hence, we interpret, with reasonable confidence, that the discrete layers shown in the velocity sections do not necessarily represent true layering in a physical or geologic sense, but instead are our best representation of a velocity function gradually increasing with depth due to closing of fractures and pore spaces related to the depth of burial.

Two holes have been drilled near the line of sections, USW VH-1 (762 m total depth), $2 \mathrm{~km}$ west of the Crater Flat profile (figs. 3.1 and 3.3), and the US Borax hole ( $323 \mathrm{~m}$ total depth) along the Beatty profile (figs. 3.1 and 3.4). Both holes are relatively shallow compared to depths obtained from the present survey, and neither penetrated the prevolcanic surface.

Drill hole USW VH-1 (fig. 3.3) penetrated principally welded tuff below $155 \mathrm{~m}$ (Carr, 1982) and bottomed in the densely welded Bullfrog Member of the Crater Flat Tuff. A downhole velocity survey depicts a ragged curve, which we have approximated by three layers. The upper two have average velocities of 1.9 and $3.0 \mathrm{~km} / \mathrm{s}$, which are somewhat higher than the 1.5 and $2.5 \mathrm{~km} / \mathrm{s}$ velocities of layers 1 and 2 (fig. 3.3). Layer 3 of the velocity survey, which begins $70 \mathrm{~m}$ deeper than layer 3 of figure 3.3, has an average velocity of $3.6 \mathrm{~km} / \mathrm{s}$, which is the same as that shown in the velocity section. Clearly, a closer match between velocities would be preferred in the very shallow section. Part of the discrepancy may be attributed to the assumed eastward dip of the Tertiary rocks at the location of shotpoint 14 (W.J. Carr, USGS, written commun., 1985), and the local presence of $20 \mathrm{~m}$ of dense basalt in drillhole USW VH-1. Furthermore, analysis of shallow seismic-refraction data and velocity logs at Yucca Mountain shows extreme variability in the velocity of the shallow volcanic rocks, and values obtained at a single drill hole may not be representative of an area. Hence, average values obtained over a broad area by refraction methods may be more representative than values obtained at a specific point location.

On the Beatty profile (fig. 3.4); Paleozoic rocks occur near the surface west of shotpoint 18 . The $4.8 \mathrm{~km} / \mathrm{s}$ velocity in the surface layer, therefore, indicates that these rocks are fractured, but that fractures are essentially closed or much less abundant at depths ranging between 400 and $700 \mathrm{~m}$, where velocities reach $5.7 \mathrm{~km} / \mathrm{s}$. East of shotpoint 18, the seismic line runs along the north foot of Bare Mountain, entirely within tuff, but generally parallel to a major fault that dips northward and drops the tuff down along the north edge of Bare Mountain. The US Borax hole east of shotpoint 18 (fig. 3.4) bottomed at $323 \mathrm{~m}$ in rhyodacite lava under the thick, welded Tram Member of the Crater Flat Tuff (W.J. Carr, USGS, written commun., 1985), within the seismic layer of $4.7 \mathrm{~km} / \mathrm{s}$ velocity. However, projection of the northward dip of the fault at the north edge of Bare Mountain suggests that the prevolcanic surface may also lie within this velocity layer. Our interpretation, indicated by the queried stippled region in figure 3.4 , assumes that fractured prevolcanic rocks of approximately $4.7 \mathrm{~km} / \mathrm{s}$ lie beneath the welded tuffs, and that fractures are closed at depths below approximately 300 to $1,300 \mathrm{~m}$, where velocities are between 5.7 and $5.9 \mathrm{~km} / \mathrm{s}$.

The intrinsic seismic velocity of crystalline and other dense rocks devoid of cracks is approximately $6 \mathrm{~km} / \mathrm{s}$; joints, fractures, and weathering tend to lower this value. Beneath Crater Flat (fig. 3.3) the approximately horizontal layers 1 through 4 show the increase in velocity with depth in the thick sequence of volcanic rocks. Layer 5 , of 4.7 to $4.8 \mathrm{~km} / \mathrm{s}$ velocity, begins at a depth of approximately $1,600 \mathrm{~m}$, and continues to a maximum depth of approximately $3,200 \mathrm{~m}$ beneath shotpoint 14 . The prevolcanic surface may lie within this layer; however, we believe that confining pressures at these depths should be sufficient to close most cracks and pores and raise velocities of a hypothetical prevolcanic surface in this layer to well above $5 \mathrm{~km} / \mathrm{s}$. Thus, we interpret the 4.7 to $4.8 \mathrm{~km} / \mathrm{s}$ layer beneath Crater Flat as comprising the deeper portion of the volcanic section filling the Crater Flat depression and the pre-volcanic rock surface (shown by solid squares) as being represented by the basal 5.7 to 6.1 $\mathrm{km} / \mathrm{s}$ layer.

At the south boundary of Crater Flat (fig. 3.3), the velocity of layer 5 changes from $4.8 \mathrm{~km} / \mathrm{s}$ beneath Crater Flat to $5.4 \mathrm{~km} / \mathrm{s}$ beneath southern Yucca Mountain, accompanied by a rise in elevation of approximately $600 \mathrm{~m}$. This velocity change implies a corresponding lateral change in rock properties, which we suggest represents a transition from the volcanic rocks beneath Crater Flat to shallower, prevolcanic rocks beneath southern Yucca Mountain. Thus, the prevolcanic surface appears to transect layer 5 and emerge as the top of layer 5 beneath southern Yucca Mountain. Here its velocity ( 4.9 to $5.4 \mathrm{~km} / \mathrm{s}$ ) is less than beneath Crater Flat (5.7 to $6.1 \mathrm{~km} / \mathrm{s})$, perhaps because of less lithostatic load on the pre-Tertiary rocks at southern Yucca Mountain. This interpretation, of relatively high-standing prevolcanic rocks below southern Yucca Mountain, agrees remarkably well with the gravity model of Snyder and Carr (1982) along their section $A-A^{\prime}$ (see fig. 3.1), which is perpendicular to the structural trend. Their gravity model shows an abrupt rise of the prevolcanic surface at the intersection with the seismic profile, rising from $2,000 \mathrm{~m}$ below sea level to $400 \mathrm{~m}$ below sea level, as compared to our interpretation (at approximately $20^{\circ}$ to the structural trend) of a more gradual apparent rise 

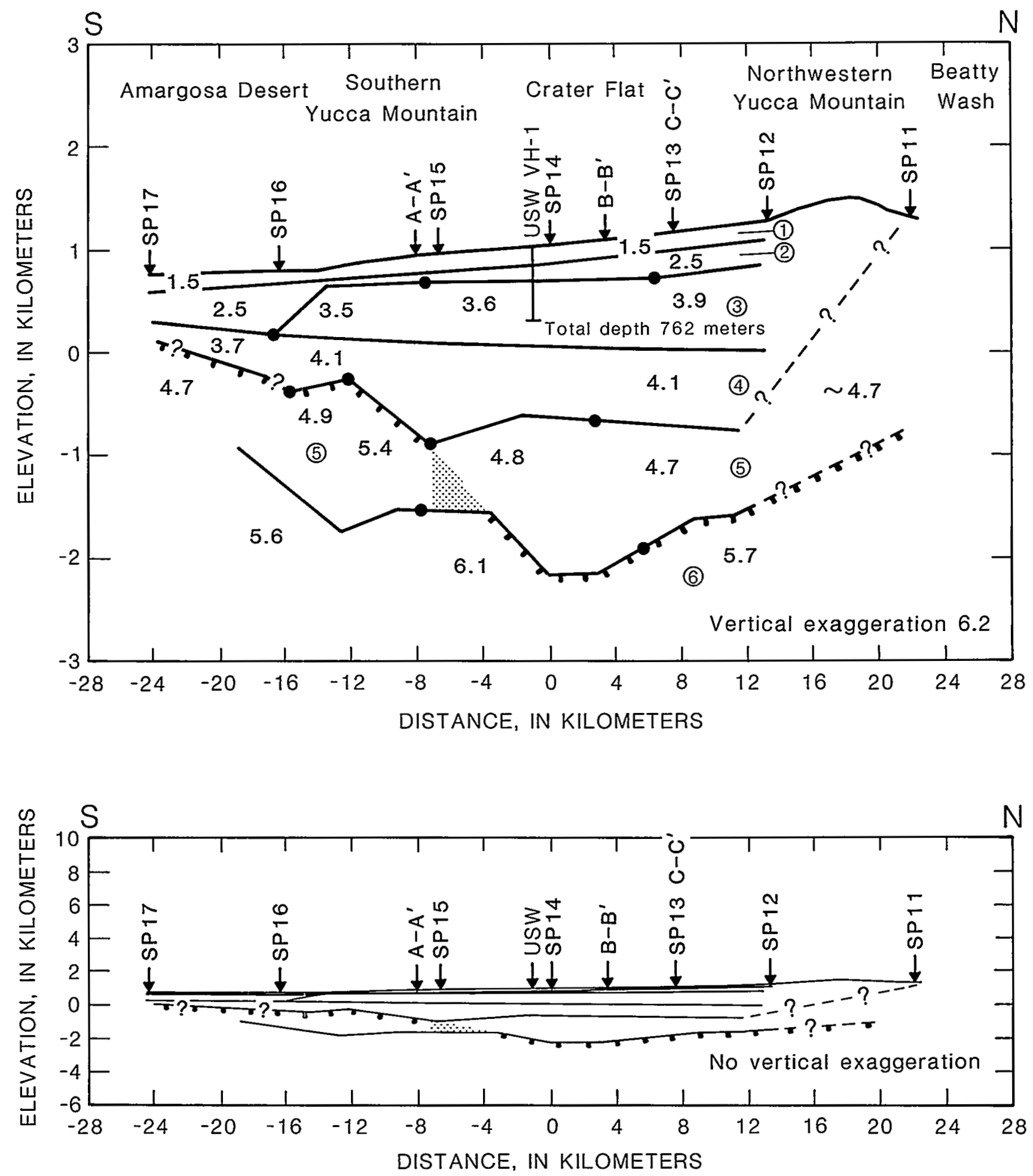

Figure 3.3. Crustal velocity section along Crater Flat profile at 6.2 times vertical exaggeration (top) and at true scale (bottom). Velocities (decimal numbers) are in kilometers per second. inferred prevolcanic surface is shown by solid squares and zones of uncertainty by stipple pattern, queries, and dashed lines. Also shown are shotpoints (SP), layer numbers (circled), intersections with gravity profiles $A-A^{\prime}, B-B^{\prime}$, and $C-C^{\prime}$ (fig. 3.1), and projection of drill hole USW VH-1. Dots show approximate location of lateral changes in velocity. 

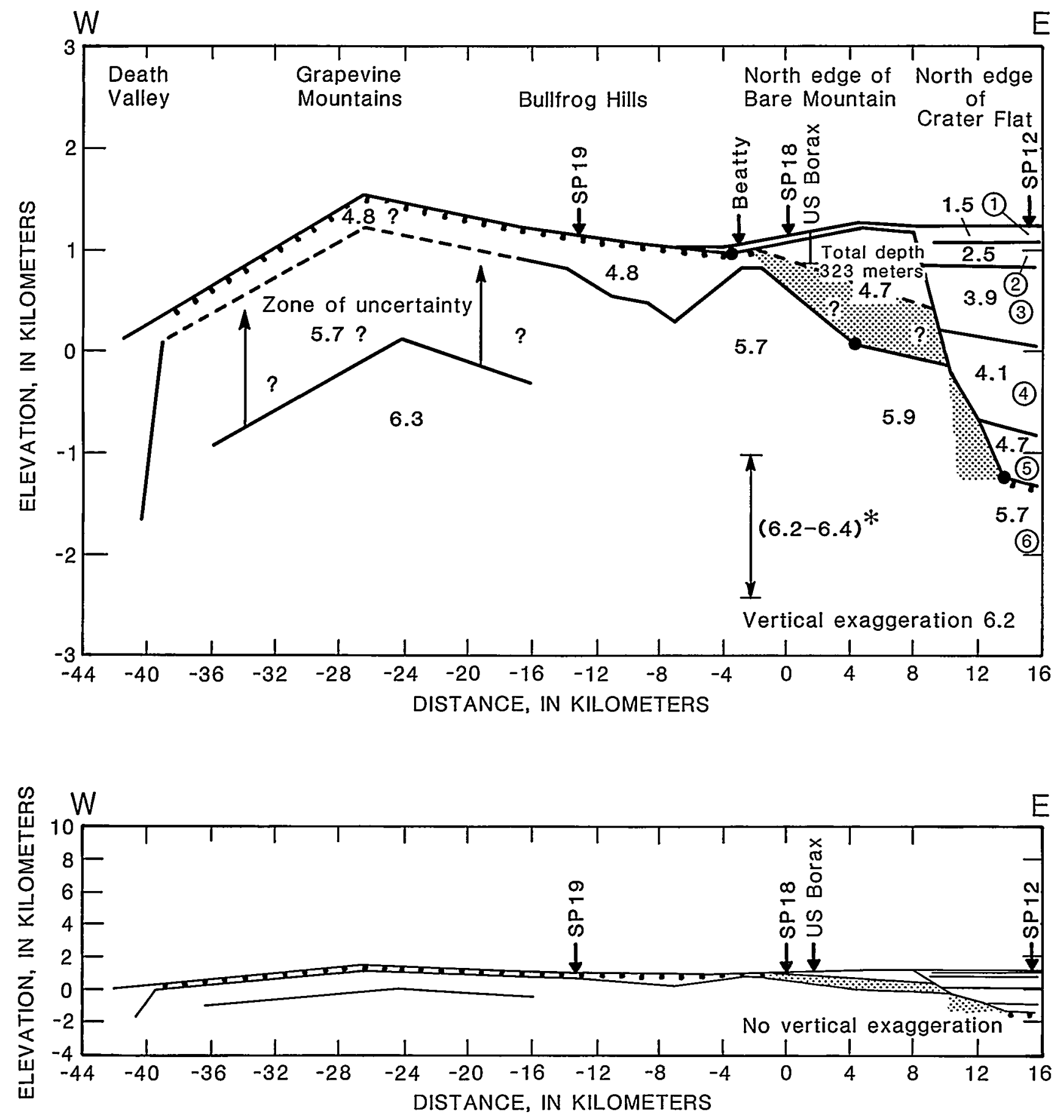

Figure 3.4. Crustal velocity section along Beatty profile at 6.2 times vertical exaggeration (top) and at true scale (bottom). Velocities (decimal numbers) are in kilometers per second. Inferred prevolcanic surface shown by solid squares and zones of uncertainty by stipple pattern, queries, and dashed lines. Also shown are shotpoints (SP), layer numbers (circled), and projection of drill hole US Borax. Dots show approximate location of lateral changes in velocity. Portion of profile from Crater Flat to Bullfrog Hills has reversed seismic coverage; that from Bullfrog Hills to Death Valley is unreversed. Shotpoint 12 (fig. 3.1) is common with Crater Flat profile. Star and double arrow indicate possible range in depth to a 6.2 to $6.4 \mathrm{~km} / \mathrm{s}$ layer (Hoffman and Mooney, 1983). 
from $1,600 \mathrm{~m}$ to $300 \mathrm{~m}$ below sea level. Furthermore, stratigraphic and structural data (Robert B. Scott, III, USGS, written commun., 1984) from the surface in southern Yucca Mountain also suggest a topographic high predating the deposition of the Paintbrush Tuff, which may reflect a high on the prevolcanic rock surface.

Southward on the Crater Flat profile, from southern Yucca Mountain into the Amargosa Desert valley, layer 5 decreases in velocity to $4.7 \mathrm{~km} / \mathrm{s}$ and in depth to about $700 \mathrm{~m}$ at shotpoint 17 . Although a $4.7 \mathrm{~km} / \mathrm{s}$ velocity appears possible for Paleozoic or crystalline rocks at such a shallow depth, the actual rock type represented is uncertain. Nevertheless, it has been labeled with queried solid squares, suggesting a southward rise of the prevolcanic surface beneath the Amargosa Desert valley.

Geophones were not emplaced across northwestern Yucca Mountain beyond shotpoint 12 . Therefore the shallow velocity structure beneath this part of the profile could not be determined. However, analysis of the traveltimes from horizons 5 and 6 for shotpoint 11 in Beatty Wash, recorded in Crater Flat, shows that velocities both beneath shotpoint 11 and the deeper part of the section beneath northwestern Yucca Mountain are significantly higher than within Crater Flat. The corresponding decreased delay times may be accounted for by projecting horizon 5 from below shotpoint 12 to near the surface at shotpoint 11 with a velocity of approximately $4.7 \mathrm{~km} / \mathrm{s}$, and projecting a corresponding rise of the prevolcanic surface beneath northwestern Yucca Mountain, shown by queried dashed lines in figure 3.3. Shotpoint 11 lies just inside the Timber Mountain-Oasis Valley caldera complex (fig. 3.1 ). The results from this single shotpoint suggest a marked velocity increase from Crater Flat northward into the Timber Mountain area.

Gravity modeling (Snyder and Carr, 1982) along section C-C' (fig. 3.1) indicates that volcanic rocks could extend as deep as 5,000 $\mathrm{m}$ beneath the surface within Crater Flat. Snyder and Carr also discussed a three-dimensional gravity model with a prevolcanic rock surface at approximately $3,500 \mathrm{~m}$ depth $(2,500 \mathrm{~m}$ below sea level). We suggest that the latter model is the more accurate given the present seismic interpretations (fig. 3.3), which indicate that volcanic rocks do not extend beyond $3,200 \mathrm{~m}$ depth.

The unreversed seismic-refraction profile by Hoffman and Mooney (1983) is approximately coincident with the gravity traverse B-B' (fig. 3.1) of Snyder and Carr (1982), and was interpreted with reference to their two dimensional gravity model. Hoffman and Mooney concluded that a layer with a velocity of $5.7 \mathrm{~km} / \mathrm{s}$ occurs at a depth of $2,200 \mathrm{~m}$ below sea level in central Crater Flat and interpreted it to represent prevolcanic rocks on the basis of its high velocity. The present Crater Flat profile crosses their earlier profile between shotpoints 13 and 14, where we have independently interpreted the same depth to a prevolcanic rock surface with a velocity between 5.7 and $6.1 \mathrm{~km} / \mathrm{s}$.

The salient feature of the Beatty profile (fig. 3.4) is the large displacement of the interpreted prevolcanic surface, marked by stipple, at the boundary between the north edge of Bare Mountain and the Crater Flat depression. Approximately $6 \mathrm{~km}$ to the east, near shotpoint 12 , interpretation of the seismic profiles places the prevolcanic rock surface at a depth of about $2,600 \mathrm{~m}$. The total fault displacement at this location is indeterminate due to complicating factors introduced by the intersecting east-west-trending fault discussed earlier, at the north foot of Bare Mountain. Approximately $3 \mathrm{~km}$ to the south, however, Paleozoic rocks at Bare Mountain are exposed at the surface, and the depth to the interpreted prevolcanic surface remains approximately the same. Therefore, we infer approximately $2,600 \mathrm{~m}$ of Tertiary (?) fault displacement near the northeast edge of Bare Mountain.

The portion of the Beatty profile between Death Valley and the Bullfrog Hills (fig. 3.4) is unreversed. Therefore, layer velocities and depths are poorly constrained and numerous solutions are possible. For example, data from the indicated 4.8 and $5.7 \mathrm{~km} / \mathrm{s}$ layers were recorded only within $6 \mathrm{~km}$ west of shotpoint 19, due in part to the large offset (fig. 3.1) of the seismic line there. The boundary (dashed line, fig. 3.4) between these two layers has simply been extrapolated from shotpoint 19 west to Death Valley.

Although velocities and depths in the Grapevine Mountains area remain highly speculative, two conclusions can be drawn with certainty. The first is the existence of a large thickness of low-velocity material at the boundary between the Grapevine Mountains and Death Valley, shown in figure 3.4 by the abrupt termination of the $5.7 \mathrm{~km} / \mathrm{s}$ horizon. The second is a layer shown beneath the Grapevine Mountains, whose approximate velocity is $6.3 \mathrm{~km} / \mathrm{s}$. The possible continuation of this layer northeastward beneath the Bullfrog Hills could not be determined without additional shotpoints. Choosing alternate ray paths permits this $6.3 \mathrm{~km} / \mathrm{s}$ layer to be moved up beneath the Grapevine Mountains by as much as 500 to $1,000 \mathrm{~m}$, indicated in figure 3.4 by the two queried arrows pointing upward. A shallower depth, however, would require a significant downward displacement or disappearance of the $6.3 \mathrm{~km} / \mathrm{s}$ layer beneath the Bullfrog Hills, but Hoffman and Mooney (1983) did identify a seismic layer of $6.2-6.4 \mathrm{~km} / \mathrm{s}$ at a depth $1.0-2.4 \mathrm{~km}$ below sea level beneath Beatty, as shown in figure 3.4. Several additional shotpoints would have helped to resolve the problem of depth to the $6.3 \mathrm{~km} / \mathrm{s}$ layer beneath the entire Beatty profile.

\section{VELOCITY, DENSITY, AND DEPTH RELATIONS}

The relations of density and velocity vs depth, shown in figure 3.5, were obtained from borehole gravity measurements and gamma-gamma logs in drill hole USW H1, located at the proposed repository site on Yucca Mountain (Snyder and Carr, 1982, 1984). It shows a linear increase in density with depth of $0.26 \mathrm{~g} / \mathrm{cm}^{3}$ per kilometer. A similar gradient and lithologic sequence is assumed in Crater Flat. The layered velocity distribution at shotpoint 14 of the Crater Flat 
profile, shown by the step functions, has been roughly approximated on the assumption of a more uniform increase in velocity with depth by three linear segments labeled $A$, $B$, and $C$ with respective gradients of $6,0.9$, and $0.4 \mathrm{~km} / \mathrm{s}$

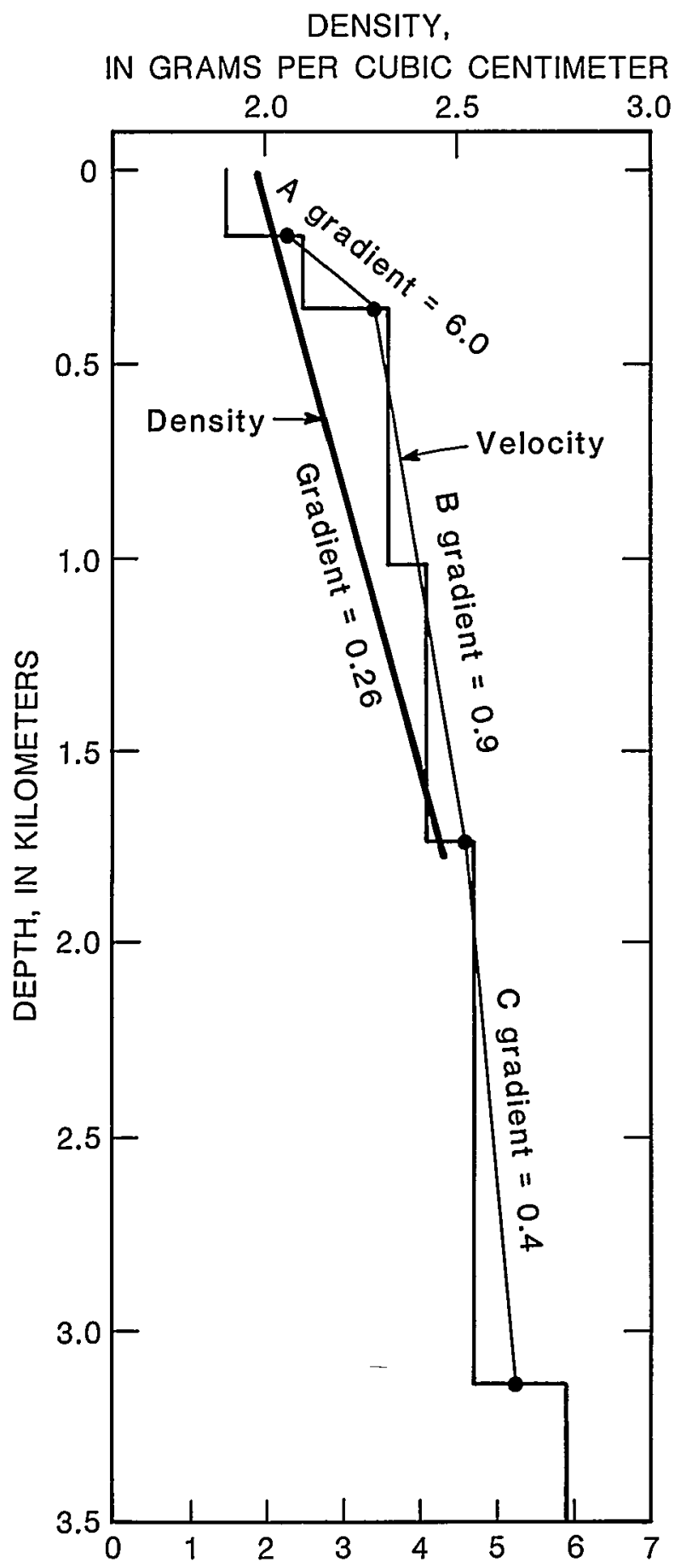

VELOCITY, IN KILOMETERS PER SECOND

Figure 3.5. Plots of velocity and density against depth. Density plot is from Snyder and Carr $(1982,1984)$. Velocity step functions are from Crater Flat portion of figure 3.3. Line segments $A, B$, and $C$ are smoothed representations of step functions. per kilometer. The gradient of segment $\mathrm{C}$ is constrained on the assumption of a possible maximum velocity of $5.2 \mathrm{~km} / \mathrm{s}$ in the volcanic section, suggested by a 4,170-m-deep borehole (UE20f, not shown) in the Silent Canyon caldera (Pahute Mesa) that penetrated $468 \mathrm{~m}$ of lava and welded rhyolitic tuff in the deepest part of the hole having a maximum velocity of $5.1 \mathrm{~km} / \mathrm{s}$ and bulk density of $2.56 \mathrm{~g} / \mathrm{cm}^{3}$ (Carroll, 1966). The decrease in gradient of the velocity curve at $1,750 \mathrm{~m}$ depth, which also marks the greatest depth of measured borehole densities, suggests a similar decrease in the gradient of the density curve.

In a plot of velocity against density (fig. 3.6), which may be representative of the Yucca Mountain region, segments A and B, obtained from the parametric plots in figure 3.5, represent the welded tuff. The point P1 (velocity $6.4 \mathrm{~km} / \mathrm{s}$, density $2.75 \mathrm{~g} / \mathrm{cm}^{3}$ ) was obtained from logs in drill hole UE-25P1 (fig. 3.1) (Muller and Kibler, 1984) and is representative of $661 \mathrm{~m}$ of Paleozoic dolomite penetrated at depths below about $1,200 \mathrm{~m}$. We have connected point P1 with segment $B$ in figure 3.6, and suggest that this part of the density-velocity plot roughly approximates both the prevolcanic and the volcanic rocks having velocities greater than $4.7 \mathrm{~km} / \mathrm{s}$. The point $P M$ (velocity $5.1 \mathrm{~km} / \mathrm{s}$, density 2.56 $\mathrm{g} / \mathrm{cm}^{3}$ ) from the deep drillhole UE20f at Pahute Mesa, plots slightly above this line.

No previous density determinations have been made for the prevolcanic rocks beneath Crater Flat here interpreted to have velocities between 5.7 and $6.1 \mathrm{~km} / \mathrm{s}$. Densities between 2.64 and $2.70 \mathrm{~g} / \mathrm{cm}^{3}$ can be extracted from the density-velocity plot (fig. 3.6). These values may represent approximate typical density values for deeply buried

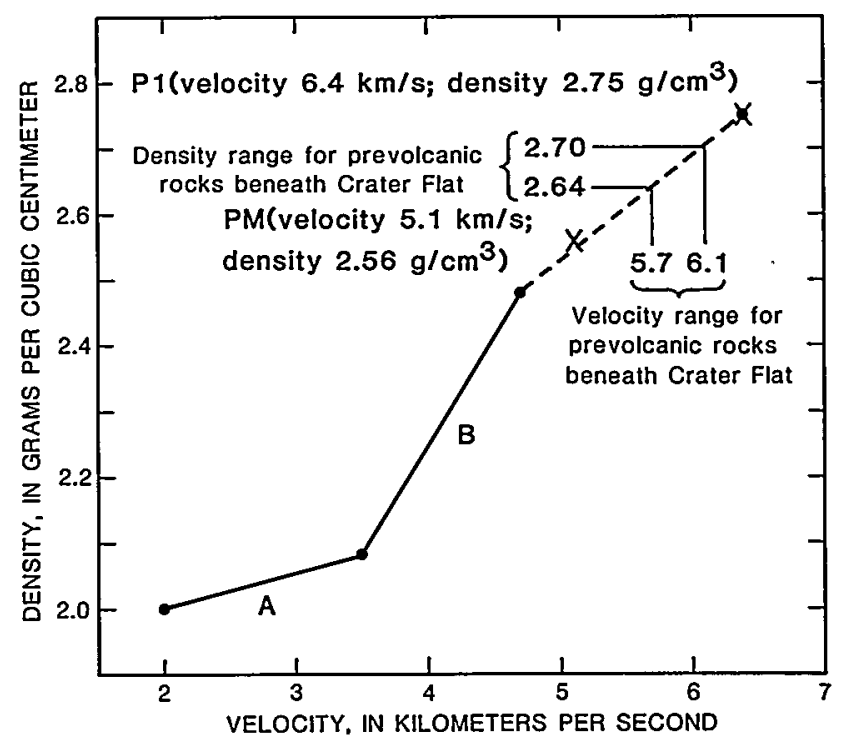

Figure 3.6. Plot of velocity against density. Segments A and B derived from figure 3.5. Point $P 1$ obtained from prevolcanic rocks in drill hole UE-25P1 (fig. 3.1) on east side of Yucca Mountain, and point PM from volcanic rocks in drill hole UE2Of (not shown) on Pahute Mesa. 
prevolcanic rocks in this region. On the other hand, densities between 2.7 and $2.8 \mathrm{~g} / \mathrm{cm}^{3}$ were required for the rocks in Bare Mountain (Snyder and Carr, 1982) to satisfy gravity data, which implies that the Paleozoic rocks composing the core of Bare Mountain are different from the prevolcanic rocks beneath Crater Flat. However, differences may be due to a disordered state of the prevolcanic rocks under Crater Flat rather than to any lithostratigraphic difference.

On the basis of the conclusions discussed above, a new gravity model (fig. 3.7) has been constructed from Death Valley to Crater Flat that approximates the Beatty seismic profile (fig. 3.4). Densities were selected to match the velocity values suggested by figure 3.6 . This gravity model indicates that the $6.3 \mathrm{~km} / \mathrm{s}\left(2.74 \mathrm{~g} / \mathrm{cm}^{3}\right)$ layer dips eastward from the Grapevine Mountains to Bare Mountain at depths from $1,000 \mathrm{~m}$ above to $1,500 \mathrm{~m}$ below sea level. Thus, the gravity model suggests continuity between the $6.2-6.4 \mathrm{~km} / \mathrm{s}$ layer beneath Beatty (Hoffman and Mooney, 1983) and the
$6.3 \mathrm{~km} / \mathrm{s}$ layer beneath the Grapevine Mountains described in this study.

\section{POSSIBLE RELATION OF GEOPHYSICAL DATA TO DETACHMENT FAULTS}

A low-angle fault or detachment surface is exposed about $10 \mathrm{~km}$ south of the Beatty profile in the Grapevine Mountains at an elevation of about $1,000 \mathrm{~m}$ above sea level (Monsen, 1983; Giarmita and others, 1983). This structure, called the Boundary Canyon fault, juxtaposes a highly fractured Paleozoic section upon a metamorphosed Precambrian and lower Paleozoic section. The seismic and gravity interpretations presented here suggest the possibility that this fault surface may correspond to the $6.3 \mathrm{~km} / \mathrm{s}, 2.74 \mathrm{~g} / \mathrm{cm}^{3}$ horizon and continue east of the Grapevine Mountains beyond the Bullfrog Hills area as far as the fault separating Bare Mountain and Crater Flat.
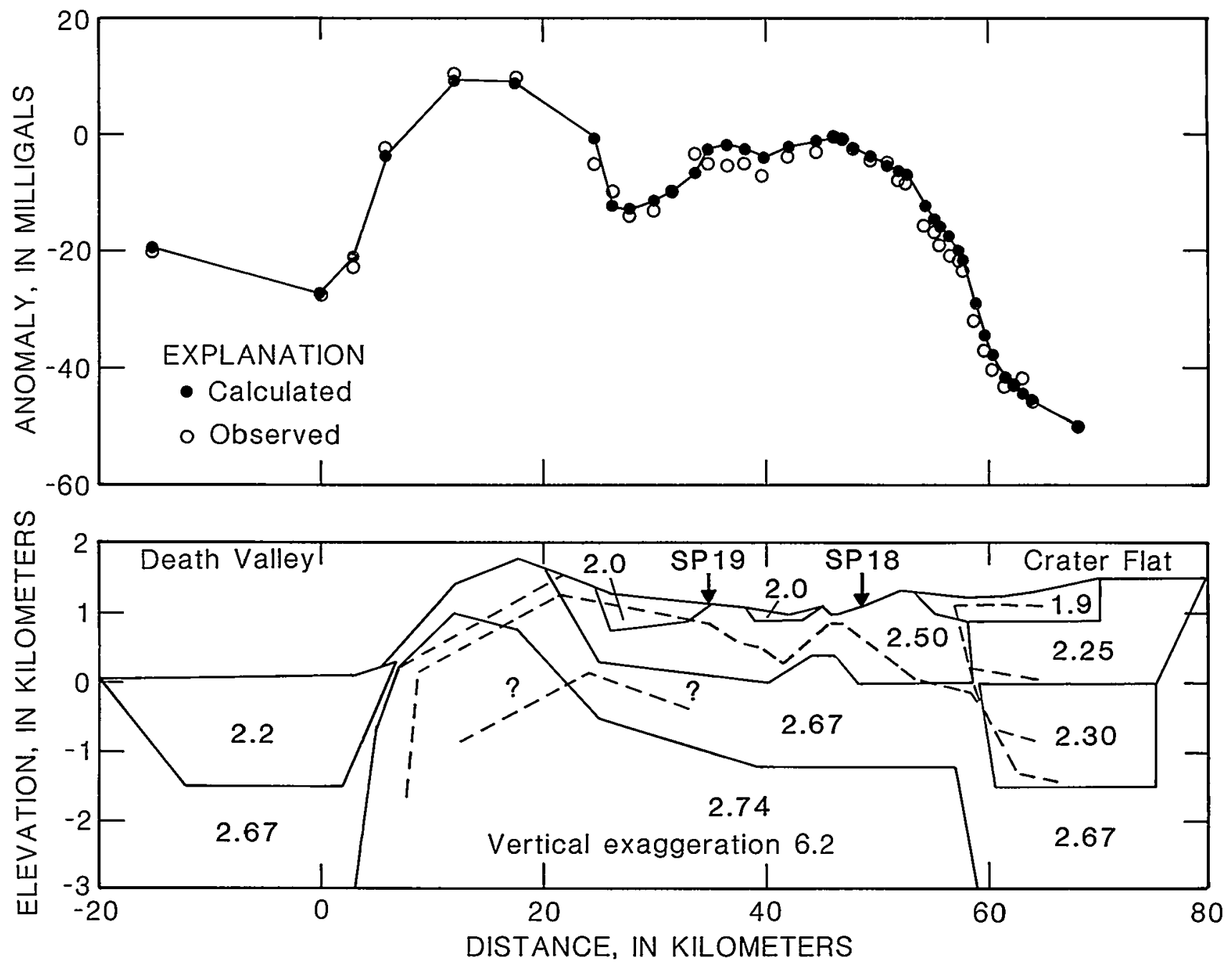

Figure 3.7. Two-dimensional gravity model approximately coincident with seismic-refraction section in figure 3.4. Values are in grams per cubic centimeter and indicated bodies are assumed homogeneous. Densities from figure 3.6. Observed gravity values from Healey and others (1980). Dashed lines show velocity section of figure 3.4; shotpoint, SP. 


\section{CONCLUSIONS}

The interpretation of seismic-refraction velocity sections indicates that volcanic rocks have a maximum thickness of about 3,200 $\mathrm{m}$ in Crater Flat (fig. 3.3), filling a depression interpreted by Snyder and Carr $(1982,1984)$ and Carr and others (1986) as a caldera complex. The depression is $25-30 \mathrm{~km}$ long in a north-south direction and about $20 \mathrm{~km}$ wide east-west. The prevolcanic rock surface exhibits some 2,000 m of vertical relief between the south end of Yucca Mountain and the center of Crater Flat. A fault on the east side of Bare Mountain (fig. 3.4) downdrops exposed Paleozoic rocks about 2,600 m into Crater Flat.

The seismic velocities of the prevolcanic rocks are between 5.7 and $6.1 \mathrm{~km} / \mathrm{s}$ within the deeper parts of the Crater Flat depression, where lithostatic loading has closed fractures. At shallower depth, velocities of the prevolcanic rocks may be less, possibly as low as $4.7 \mathrm{~km} / \mathrm{s}$ within approximately $1,000 \mathrm{~m}$ of the surface.

The velocities in the volcanic section beneath Crater Flat reach 4.7 to $4.8 \mathrm{~km} / \mathrm{s}$ at a depth of approximately $1,600 \mathrm{~m}$. However, data from a single offset shotpoint (shotpoint 11) in Beatty Wash, just within the Timber MountainOasis Valley caldera, suggest that volcanic rocks beneath the northwestern part of Yucca Mountain reach a $4.7 \mathrm{~km} / \mathrm{s}$ velocity at considerably shallower depth and are near the surface beneath shotpoint 11 .

A graph of density against velocity, which may be representative of the volcanic and prevolcanic rocks in the Yucca Mountain region, has been determined (fig. 3.6). Based on this graph, a gravity model approximately coincident with the Beatty profile suggests that the Boundary Canyon detachment fault, exposed in the Grapevine Mountains, may be continuous as far east as Bare Mountain.

\section{REFERENCES CITED}

Ackermann, H.D., Pankratz, L.W., and Dansereau, D.A., 1982, A comprehensive system for interpreting seismic-refraction arrival-time data using interactive computer methods: U.S. Geological Survey Open-File Report 82-1065, 265 p.

1983, Computer program modifications of Open-File Report 82-1065: A comprehensive system for interpreting seismic-refraction arrival-time data using interactive computer methods: U.S. Geological Survey Open-File Report 83-604, 2 p.

Barry, C.T., 1980, A study of the vertical vibrator source for seismic profiling in the Yucca Mountain area of the Nevada Test Site: Colorado School of Mines, Master of Engineering Thesis, ER 2429, 58 p.

Byers, F.M., Jr., Carr, W.J., Orkild, P.P., Quinlivan, W.P., and Sargent, K.A., 1976, Volcanic suites and related cauldrons of Timber Mountain-Oasis Valley caldera complex, southern Nevada: U.S. Geological Survey Professional Paper 919, 70 p.

Carr, W.J., 1982, Volcano-tectonic history of Crater Flat, southwestern Nevada, as suggested by new evidence from drill hole USW-VH-1 and vicinity: U.S. Geological Survey Open-File
Report 82-457, 23 p.

1984, Regional structural setting of Yucca Mountain southwestern Nevada, and late Cenozoic rates of tectonic activity in part of the southwestern Great Basin, Nevada and California: U.S. Geological Survey Open-File Report 84-854, 109 p.

Carr, W.J., Byers, F.M., Jr., and Orkild, P.P., 1986, Stratigraphic and volcano-tectonic relations of Crater Flat Tuff and some older volcanic units, Nye County, Nevada: U.S. Geological Survey Professional Paper 1323, 28 p.

Carroll, R.D., 1966, Preliminary interpretation of geophysical logs, UE20f, Pahute Mesa, Nevada Test Site: U.S. Geological Survey Technical Letter, Special Studies I-37, Supplement 1, $5 \mathrm{p}$.

Giarmita, M., Day, H.W., and Troxel, B.W., 1983, Structural metamorphic and plutonic evolution of the northern Funeral Mountains, Death Valley, California [abs.]: Geological Society of America Abstracts with Programs, v. 15, no. 5, p. 419.

Grant, F.S., and West, G.F., 1965, Interpretation theory in applied geophysics: New York, McGraw-Hill, 584 p.

Healey, D.L., Wahl, R.R., and Oliver, H.W., 1980, Bouguer gravity map of Nevada: Death Valley sheet: Nevada Bureau of Mines and Geology Map 69, scale 1:250,000.

Healy, J.H., Mooney, W.D., Blank, H.R., Gettings, M.E., Kohler, W.M., Lamson, R.J., and Leone, L.E., 1982, Saudi Arabian deep-seismic refraction profile: Final project report: U.S. Geological Survey Open-File Report 82-37, 429 p.

Hoffman, L.R., and Mooney, W.D., 1983, A seismic study of Yucca Mountain and vicinity, southern Nevada: Data report and preliminary results: U.S. Geological Survey Open-File Report 83-588, $50 \mathrm{p}$.

McGovern, T.F., 1983, An evaluation of seismic reflection studies in the Yucca Mountain area, Nevada Test Site: U.S. Geological Survey Open-File Report 83-912, 57 p.

Monsen, S.A., 1983, Structural evolution and metamorphic petrology of the Precambrian strata, northwest Bare Mountain, Nevada: Davis, University of California, M.S. thesis, $66 \mathrm{p}$.

Muller, D.C., and Kibler, J.E., 1984, Preliminary analysis of geophysical well logs from drill hole UE-25P\#1, Yucca Mountain, Nye County, Nevada: U.S. Geological Survey Open-File Report 84-649, $14 \mathrm{p}$.

Pankratz, L.W., 1982, Reconnaissance seismic refraction studies of Calico Hills, Wahmonie, and Yucca Mountain, southwest Nevada Test Site, Nye County, Nevada, U.S. Geological Survey Open-File Report 82-478, 25 p.

Snyder, D.B., and Carr, W.J., 1982, Preliminary results of gravity investigations at Yucca Mountain and vicinity, southern Nye County, Nevada, U.S. Geological Survey Open-File Report 82-701, 35 p.

1984, Interpretation of gravity data in a complex volcano-tectonic setting, southwestern Nevada: Journal of Geophysical Research, v. 89, no. B12, p. 10,193-10,206.

Stewart, J.H., 1980, Geology of Nevada: Nevada Bureau of Mines and Geology Special Publication 4, 136 p.

Sutton, V.D., 1984, Data report for the 1983 seismic refraction experiment at Yucca Mountain, Beatty and vicinity, southwestern Nevada: U.S. Geological Survey Open-File Report 84-661, 66 p.

Telford, W.M., Geldart, L.P., Sheriff, R.E., and Keys, D.A., 1976, Applied geophysics: Cambridge, U.K., Cambridge University Press, 860 p. 
$-\quad-2$ 


\title{
4. Volcano-Tectonic Setting of Yucca Mountain and Crater Flat, Southwestern Nevada
}

\author{
By Wilfred J. Carr
}

\section{CONTENTS}

\author{
Abstract 35 \\ Introduction 35 \\ Regional setting and general geologic relations 37 \\ Geologic framework of Crater Flat and Yucca Mountain 38 \\ Crater Flat Tuff and associated volcanic units $\mathbf{4 0}$ \\ Structural setting of Crater Flat and Yucca Mountain 40 \\ Age of faulting $\mathbf{4 0}$ \\ Geologic and geophysical evidence supporting a volcano-tectonic \\ depression in Crater Flat $\mathbf{4 1}$ \\ Other volcano-tectonic structure in the Yucca Mountain area 43 \\ Degree of late Cenozoic tectonic stability of Crater Flat area 46 \\ Conclusions 48 \\ References cited 48
}

tectonic depression may help explain the relatively low rate of structural activity in the area during Pliocene and Quaternary time.

\section{INTRODUCTION}

Understanding the style and mechanisms of tectonic development of the Yucca Mountain area is especially critical to evaluation of the proposed site for long-term storage of high-level nuclear waste. If, as this report attempts to substantiate, the structure of Yucca Mountain is mainly the result of middle Miocene volcano-tectonic processes, a relatively high degree of present tectonic stability is likely. In other words, if the structure in the Crater Flat-Yucca Mountain area is largely related to $15-10$ m.y.-old magmatic and volcanic processes, including caldera formation, rather than to Pliocene and Quaternary basin-range deformation, a greater relative tectonic stability may be expected during the several thousand year period critical for waste storage. This relative stability would be a result, not only of the length of time since the last main structural activity, but also of kinematic considerations that suggest that an inactive caldera regime tends to be a decoupled mass within the Earth's upper crust.

The volcano-tectonic history of the Yucca Mountain region has been studied for more than $\mathbf{3 0}$ years, but only recently has the older volcanic history of the area been well enough known to illuminate some aspects of the structural evolution. Despite the strong evidence summarized in this report, proof of caldera complexes beneath Crater Flat or northern Yucca Mountain is not at hand. Most older calderas whose topographic expression is poor to nonexistent, and whose ash-flow units are not exposed within the caldera, are necessarily inferred. The evidence for the Crater FlatProspector Pass caldera complex appears as good as, if not better than, that for most older calderas in the Basin and Range province.

Two and possibly three major caldera complexes are probably present in the vicinity of Yucca Mountain (fig. 4.1): The oldest, a pre-Crater Flat Tuff caldera, may exist beneath northern Yucca Mountain and northern Crater Flat (Carr, 1982; Carr and others, 1986), but its exact location and history cannot be determined without deep drill holes. A Crater Flat-Prospector Pass caldera complex related to the Crater Flat Tuff has recently been described (Carr, 1982; 
Carr and others, 1986); much remains unknown about this episode of volcanism, mainly because it is largely buried by younger volcanic rocks. The youngest, best exposed, and best understood of the complexes, Timber Mountain-Oasis Valley, has been described in detail (Byers and others, 1976b; Christiansen and others, 1977).

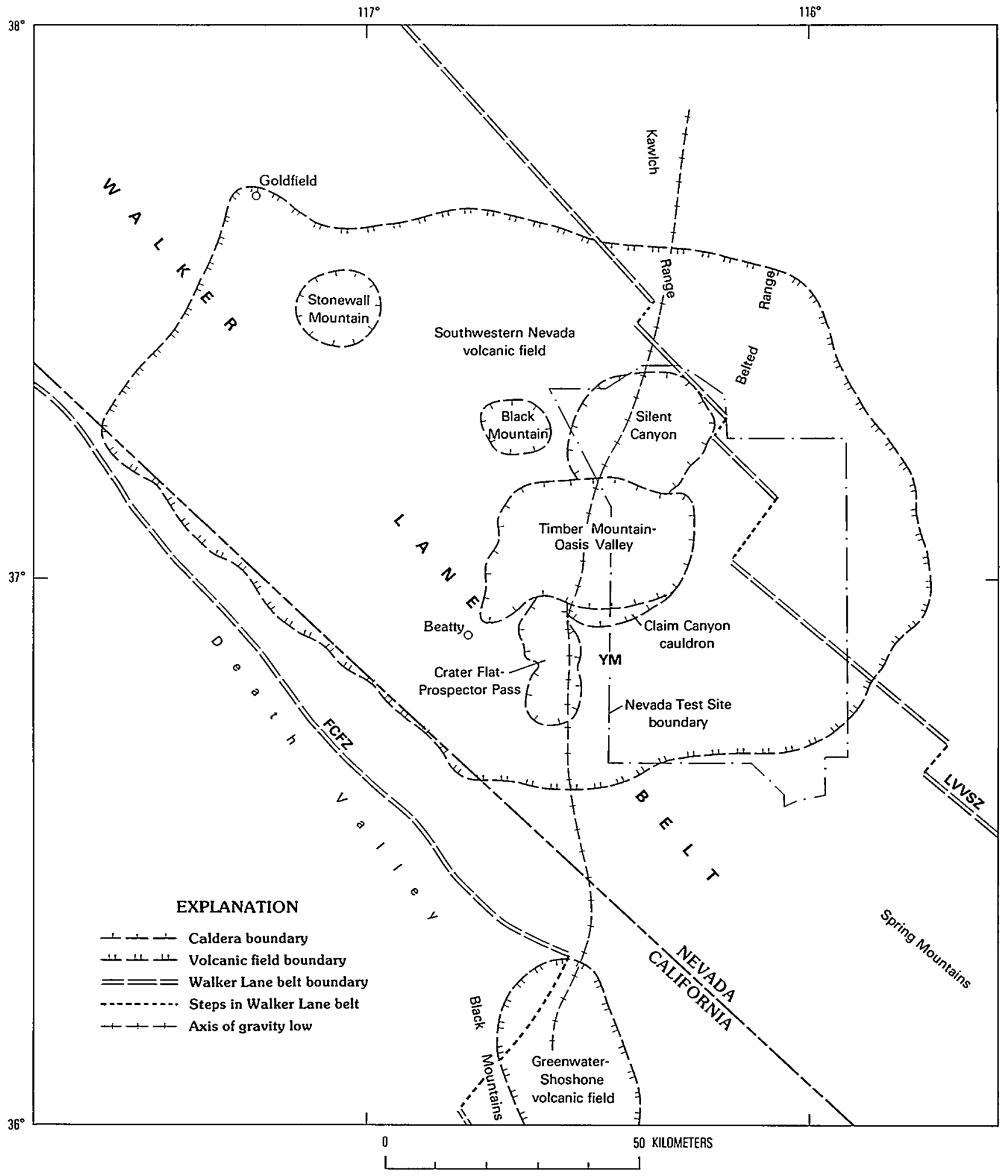

Figure 4.1. Location of Walker Lane belt in southwestern Nevada and Greenwater-Shoshone volcanic field and associated calderas. YM, Yucca Mountain; FCFZ, Furnace Creek fault zone; LVVSZ, Las Vegas Valley shear zone. 
In order to support the case for volcanism as the principal controlling process for Cenozoic tectonism in the Yucca Mountain area, this paper briefly reviews the setting and evidence for volcano-tectonic activity, mainly the caldera complex believed present in Crater Flat adjacent to Yucca Mountain. Important evidence for relative stability of the area since the middle Miocene also is discussed.

Evidence to be presented includes information from surface geology, drill holes, and geophysics. The third dimension provided by subsurface data is invaluable in constructing the structural model.

Acknowledgments.-Helpful reviews of this paper by F.A. McKeown and R.E. Anderson are gratefully acknowledged, but the interpretations are those of the author.

\section{REGIONAL SETTING AND GENERAL GEOLOGIC RELATIONS}

Yucca Mountain and Crater Flat are within the southwestern Nevada volcanic field (fig. 4.1) (Christiansen and others, 1965, 1977; Byers and others, 1976b), which consists of locally thick and, in some areas, highly faulted sequences of Tertiary silicic volcanic rocks, mainly lavas and ash-flow tuffs about 8-15 m.y. old, roughly centered around the Timber Mountain and Silent Canyon (Noble and others, 1968) calderas. Volcanic and other stratigraphic units important to discussions in this report are summarized in table 4.1.

The volcanic centers lie within the Walker Lane belt (WLB) (Carr, 1984a, b), a northwest-southeast-trending zone of diverse structure and topography, 75 to $125 \mathrm{~km}$ (50-75 mi) wide, lying between the tectonically more active InyoMono (Carr, 1984a, b) and Basin-Range subsections (fig. 4.2) of the southwestern Great Basin. Except for volcanotectonic subsidence, the WLB has been dominated by lateral shear rather than by large vertical displacements. Several northeast-striking structural zones or lineaments, some of which are seismically active (Rogers and others, 1983), occur within the WLB (fig. 4.2). Two of these zones are present near Yucca Mountain. The major caldera complexes at Silent Canyon, Timber Mountain, and Crater Flat lie along

Table 4.1. Generalized major stratigraphic units in Bare Mountain-Crater Flat-Yucca Mountain area

\begin{tabular}{|c|c|c|c|}
\hline Unit & Members & $\begin{array}{l}\text { Volcanic center } \\
\text { (figs. } 4.1,4.4 \text { ) }\end{array}$ & Age \\
\hline Alluvium--n- & --- & $-\infty$ & Quaternary to Miocene. \\
\hline Basalts-- & -- & $\begin{array}{l}\text { Crater Flat, Big Dune basalt } \\
\text { areas. }\end{array}$ & $\begin{array}{l}\text { Pliocene and } \\
\text { PIiestocene. }\end{array}$ \\
\hline $\begin{array}{l}\text { Rhyolite of Shoshone } \\
\text { Mountain; basalt of } \\
\text { Dome Mountain; rhyolites } \\
\text { of Fortymile Canyon. }\end{array}$ & $\cdots$ & $\begin{array}{l}\text { Shoshone Mountain, Fortymile } \\
\text { Canyon area. }\end{array}$ & Middle Miocene. \\
\hline Timber Mountain Tuff-...-. & $\begin{array}{l}\text { Ammonia Tanks Mbr., } \\
\text { Rainier Mesa } \\
\text { Mbr. }\end{array}$ & $\begin{array}{l}\text { Timber Mountain-0asis Valley } \\
\text { caldera complex. }\end{array}$ & Middle Miocene. \\
\hline Paintbrush Tuff-c- & $\begin{array}{l}\text { Tiva Canyon Mbr.---- } \\
\text { Topopah Spring Mbr.-- }\end{array}$ & $\begin{array}{l}\text { Claim Canyon cauldron----------- } \\
\text { Timber Mountain-0asis Valley } \\
\text { caldera complex. }\end{array}$ & $\begin{array}{l}\text { Middle Miocene. } \\
\text { Middle Miocene. }\end{array}$ \\
\hline $\begin{array}{l}\text { Wahmonie and Salyer } \\
\text { Formations. }\end{array}$ & -- & Wahmonie-Salyer center---_.-- & Middle Miocene. \\
\hline $\begin{array}{l}\text { Rhyolite lavas and } \\
\text { tuffaceous beds of } \\
\text { Calico Hills. }\end{array}$ & -- & Fortymile Canyon area- & Middle Miocene. \\
\hline Crater Flat Tuff-- & $\begin{array}{l}\text { Prow Pass Mbr., } \\
\text { Bullfrog Mbr., } \\
\text { Tram Mbr. }\end{array}$ & $\begin{array}{l}\text { Crater Flat-Prospector Pass } \\
\text { caldera complex. }\end{array}$ & Miocene. \\
\hline $\begin{array}{l}\text { Lavas of "intermediate" } \\
\text { composition. }\end{array}$ & --- & $\begin{array}{l}\text { Various sources, locations } \\
\text { poorly known. }\end{array}$ & $\begin{array}{l}\text { Middle and early } \\
\text { Miocene. }\end{array}$ \\
\hline Lithic Ridge Tuff- & -- & $\begin{array}{l}\text { Various sources, locations } \\
\text { poorly known. }\end{array}$ & $\begin{array}{l}\text { Middle and early } \\
\text { Miocene. }\end{array}$ \\
\hline Older tuffs and lavas------ & --- & $\begin{array}{l}\text { Various sources, locations } \\
\text { poorly known. }\end{array}$ & $\begin{array}{l}\text { Middle and early } \\
\text { Miocene. }\end{array}$ \\
\hline $\begin{array}{l}\text { Tuffs and sedimentary } \\
\text { rocks. }\end{array}$ & $-\cdots$ & --- & $\begin{array}{l}\text { Middle Miocene to } \\
\text { middle Oligocene. }\end{array}$ \\
\hline Granitic rocks- & -- & -- & Cretaceous. \\
\hline Sedimentary rocks-_- & --- & $\cdots$ & $\begin{array}{l}\text { Paleozoic and } \\
\text { Proterozoic }\end{array}$ \\
\hline
\end{tabular}


a regional gravity trough that spans the WLB in a location that corresponds roughly with significant right-steps in the WLB margins (fig. 4.1) (Carr, 1984b). The gravity low extends both north and south of the southwestern Nevada volcanic field, and the south end is located at the GreenwaterShoshone volcanic field east of Death Valley (fig. 4.1).

The Tertiary volcanic terrane is developed on the eroded surface of gently to moderately folded and thrustfaulted Proterozoic and Paleozoic sedimentary rocks that were intruded in Jurassic and Cretaceous time by easttrending belts of granitic plutons (Carr, 1984a).

\section{GEOLOGIC FRAMEWORK OF CRATER FLAT AND YUCCA MOUNTAIN}

Crater Flat, believed to be the source for the Crater Flat Tuff (Carr and others, 1986), is a southward-sloping basin about $10 \mathrm{~km}$ wide. It is flanked on the west by the prominent Bare Mountain structural block, composed of preTertiary rocks, and on the east by the fault-block terrane of Yucca Mountain, composed almost entirely of Miocene ashflow tuffs (fig. 4.3). On the north the basin is irregularly bounded by a complex volcanic terrane that lies between

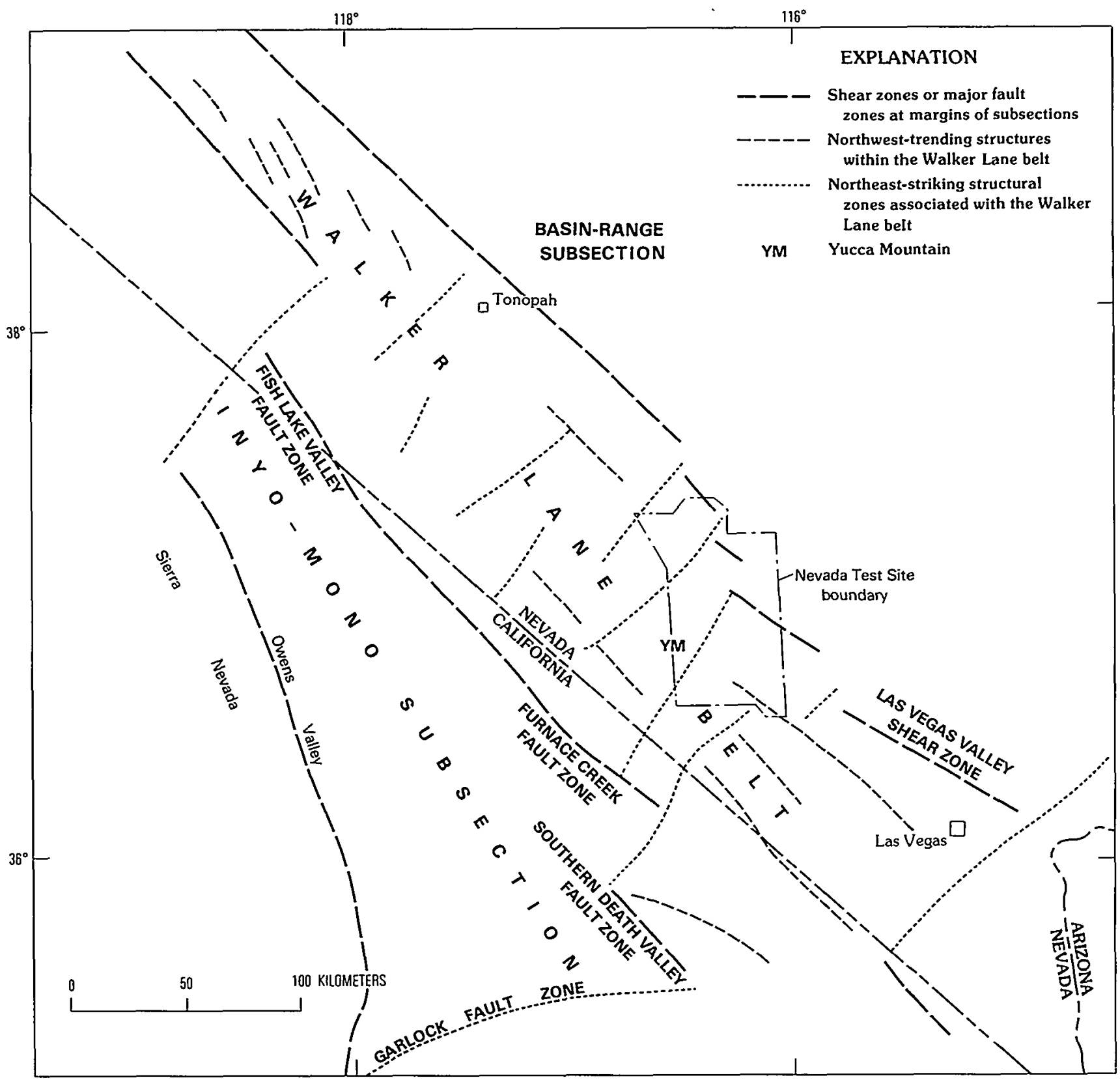

Figure 4.2. Structural-physiographic subsections of the southwestern Great Basin, and important structures of the Walker Lane belt. 


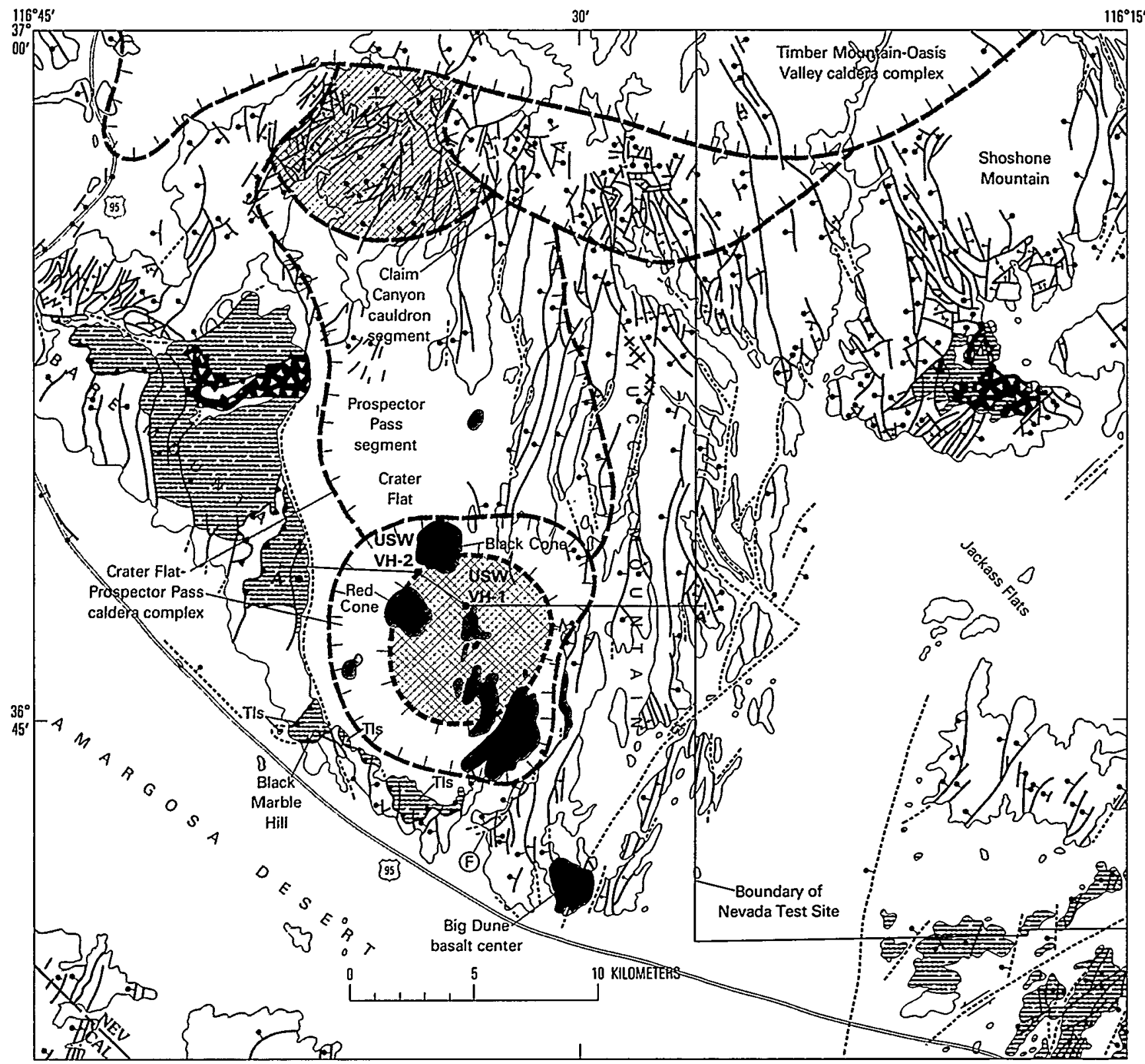

EXPLANATION
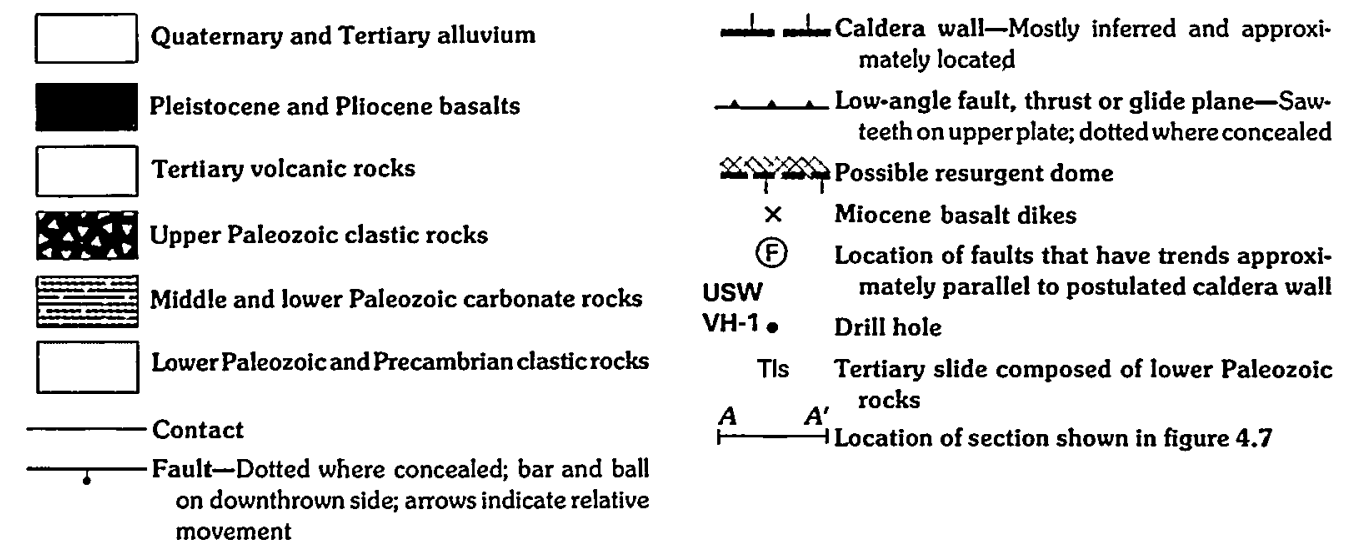

Figure 4.3. Geologic map of the Bare Mountain-Crater Flat-Yucca Mountain area. 
Crater Flat and the Timber Mountain-Oasis Valley caldera complex (Byers and others, 1976a); the latter includes the Claim Canyon cauldron segment, the probable source of the Tiva Canyon Member (table 4.1) of the Paintbrush Tuff (Byers and others, 1976b). On the south, Crater Flat is rimmed by a low arcuate ridge of relatively unfaulted tuffs, 10-m.y.-old basalt lavas, and a very extensive gravity slide block of Paleozoic rocks (unit Tls, fig. 4.3; Swadley and Carr, in press). Within Crater Flat are two groups of basalts (fig. 4.3); those in the southeast corner are about $3.8 \mathrm{~m} . y$. old, and those along a slightly curving north-northeast trend in central Crater Flat are about $1.2 \mathrm{~m} . \mathrm{y}$. old. A third young basalt, about $0.3 \mathrm{~m}$.y. old, occurs $6 \mathrm{~km}$ southeast of Crater Flat (Vaniman and others, 1982).

\section{CRATER FLAT TUFF AND ASSOCIATED VOLCANIC UNITS}

The Crater Flat Tuff (table 4.1) probably was erupted from an elongate caldera complex underlying most of Crater Flat and the area between there and the Timber Mountain caldera complex (Carr and others, 1986). The Tram Member, oldest member of the Crater Flat Tuff, is believed (Carr and others, 1986) to have originated from the Prospector Pass caldera segment in the northern part of the area (fig. 4.3), perhaps partly from within the area of the subsequent Timber Mountain caldera. The Bullfrog Member of the Crater Flat, and possibly the Prow Pass Member of the Crater Flat, are thought to have been erupted from a caldera in southern Crater Flat.

The Crater Flat Tuff is sporadically exposed in a fairly large region surrounding Crater Flat. The Crater Flat underlies the extensive, well-exposed ash-flow sheets of the Paintbrush and Timber Mountain Tuffs, and has been penetrated by numerous drill holes in the Yucca Mountain area (e.g., Spengler and others, 1981; Scott and Castellanos, 1984). In a few exposures, and in drill holes on Yucca Mountain, the Crater Flat Tuff is underlain by rhyolitic to dacitic lavas, by another ash-flow tuff called the Lithic Ridge Tuff, and by several sequences of so-called "older tuffs" (Carr and others, 1986).

\section{STRUCTURAL SETTING OF CRATER FLAT AND YUCCA MOUNTAIN}

The volcanic rocks on Yucca Mountain are displaced by a system of prominent northerly-striking normal faults, most with several hundred meters of displacement, spaced 1 to $3 \mathrm{~km}$ apart (fig. 4.3); these faults dip westward and repeat the gently $\left(5^{\circ}-20^{\circ}\right)$ east-dipping volcanic section (Lipman and McKay, 1965). It is important to note that the western part of this fault system is distinctly en echelon; that is, faults step to the left or northwestward and tend to decrease in displacement northward. The result (fig. 4.4) is a subtle arcuate net displacement down to the west along the northeast side of Crater Flat. Several subparallel faults just northeast of Yucca Mountain (Paintbrush Canyon fault system, fig. 4.4) curve gently to the northwest and cross into the Timber Mountain caldera. A few faults strike northwest on northeastern Yucca Mountain (fig. 4.3).

In contrast to the structure on Yucca Mountain, only one major fault is exposed on the west side of Crater Flata continuous, major, east-dipping fault at the foot of Bare Mountain (fig. 4.4). Except near the southeast tip of Bare Mountain, only alluvium is exposed on the downthrown side. The fault trace is composed of two arcuate segments concave toward northern and southern parts of Crater Flat. Other north-striking normal or oblique-slip faults, mainly in central and northwestern Bare Mountain, are also down to the east in the direction of Crater Flat (fig. 4.3).

Large displacement north-trending faults like those on Yucca Mountain do not occur in exposures of volcanic rocks of the same age on the northwest and south edges of Crater Flat; instead, rocks exposed in the narrow, arcuate south rim of Crater Flat are cut by only a few north-striking faults of relatively small displacement. Two faults of northeasterly trend (F, fig. 4.3) that are concave toward Crater Flat and are down toward it, could be outermost collapse faults of the caldera structure. These faults drop down a thick section of Crater Flat Tuff exposed on the ridge immediately to the south (Swadley and Carr, 1987). North of Crater Flat is a complex area with many faults of northeast trend, but also much diverse, locally chaotic structure, largely developed in rocks older than the Timber Mountain Tuff. Thus, although it is tempting to extend the prominent northtrending structural style of Yucca Mountain westward beneath Crater Flat to Bare Mountain, the exposed structure immediately north and south of Crater Flat does not support such an extrapolation, nor does available subsurface information, as will be brought out later.

\section{AGE OF FAULTING}

The age of major movements on faults exposed around Crater Flat is well constrained. Faults on Yucca Mountain, and around the northeast and southeast sides of Crater Flat, had their principal displacement in a relatively brief period after eruption of the Tiva Canyon Member of the Paintbrush Tuff, and before emplacement of the Timber Mountain Tuff, approximately 11.5-12.5 m.y. ago. This age is well established by detailed mapping in this region (see Byers and others, 1976a, Scott and Bonk, 1984; Swadley and Carr, 1987), which demonstrates that the Rainier Mesa Member of the Timber Mountain Tuff was deposited across small fault scarps and at the foot of large fault scarps developed in the Paintbrush and older tuffs (Carr, 1984a, fig. 32). In most of the Yucca Mountain area, faulting of the Timber Mountain Tuff and younger rocks has, by contrast, been minor (Carr, 1984a; Scott and Bonk, 1984). On Bare Mountain, 
to the west, north-striking dikes dated at 13.9 m.y. (Carr, 1982, p. 9) are little disturbed by faults of the same general trend. Faulting adjacent to, and locally within, the Timber Mountain-Oasis Valley caldera complex, however, caused extensive disturbance of the Timber Mountain Tuff and younger volcanic rocks, such as the rhyolites of Fortymile Canyon (table 4.1) (Byers and others, 1976a). Quaternary deposits show small displacement at several locations on Yucca Mountain, in southeastern Crater Flat, and at the east foot of Bare Mountain (Swadley and others, 1984). These Quaternary displacements occur on segments of the faults formed mainly about $12 \mathrm{~m}$.y. ago, and occur largely on portions of these faults here interpreted to be controlled, in part, by caldera structure.

\section{GEOLOGIC AND GEOPHYSICAL EVIDENCE SUPPORTING A VOLCANO-TECTONIC DEPRESSION IN CRATER FLAT}

Surface and near-surface geologic information bearing upon a volcano-tectonic and caldera interpretation of the Crater Flat area is summarized in table 4.2. Geophysical data interpreted to support the caldera model are summarized in table 4.3.

Although no single feature listed in tables 4.2 and 4.3 proves the presence of a caldera complex in Crater Flat, taken together the evidence is good, at least for volcano-tectonic subsidence of a large area west and north of Yucca Mountain. Large-scale subsidence prior to emplacement of the

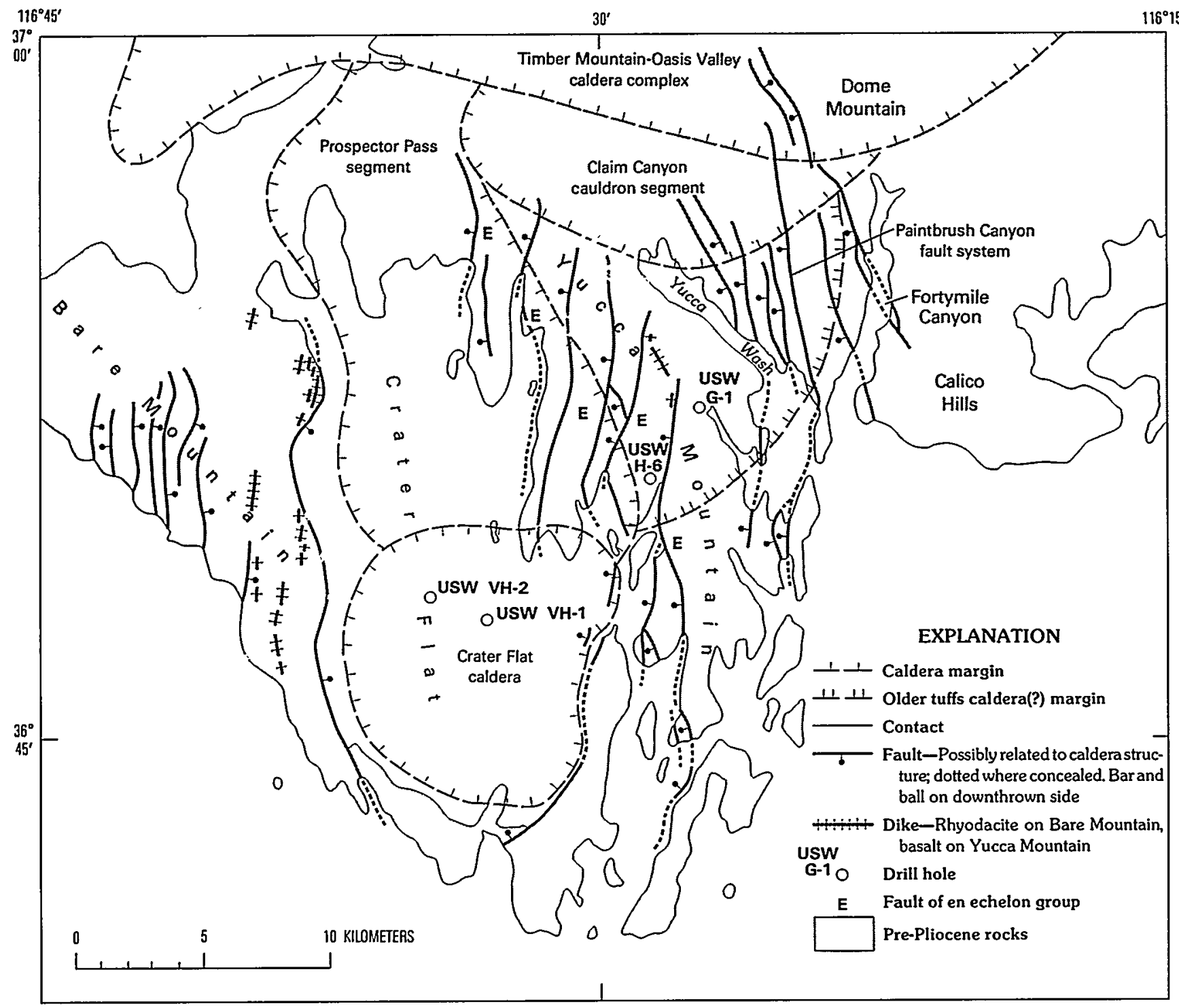

Figure 4.4. Relation between basin-range faults and calderas, Yucca Mountain area. 
Table 4.2. Geologic evidence of caldera complex in Crater Flat

Evidence or feature of southern Crater Flat.

Two northeast-striking curved faults occur near the southeast margin of Crater Flat (E, fig. 4.3), where they drop a thick section of Crater Flat Tuff down toward Crater Flat.

A gently arcuate system of $13.9-\mathrm{m} . \mathrm{y} .-$ old dikes on eastern Bare Mountain, slightly concave toward Crater Flat (figs. 4.4, 4.5); dikes are locally in small faults that show little or no post-dike movement.

Lavas similar to the dikes on Bare Mountain underlie the Tram Member in a large area roughly centered about Crater Flat (fig. 4.5).

Northwest of Crater Flat, altered Tram Member appears to be abruptly thinner outside a partly buried curving structure. Pre-Tram lavas occur near this boundary (fig. 4.5).1

Pattern of diverse fault trends in area between Crater Flat and Beatty Wash occurs in an area of thick Tram Member.

Distribution of the welded ash-flow tuff members of the Crater Flat Tuff is roughly centered about Crater Flat (Carr and others, 1986).

Breccia at the top of the Bullfrog Member near the south rim of Crater Flat (Swadley and Carr, in press).

Densely welded, granophyric Bullfrog Member more than $141 \mathrm{~m}$ thick (base not reached) occurs in bottom of drill hole USW VH-1 (figs. 4.4, 4.7; Carr, 1982).

Pliocene and Pleistocene basalts in central and southern Crater Flat (fig. 4.3).

Basin-range-style structure east of Crater Flat is not well developed within caldera or at north and south margins.
Interpretation or comment

Arcuate, caldera-like topographic boundaries are present on the west, south, and southeast margins crater Flat.

The faults could be segments of the outermost caldera fault zone.

The dikes are about the same age and petrographically similar to parts of the Tram Member and underlying Lithic Ridge Tuff and associated lavas. Dikes may occupy early incipient outer ring fractures of the caldera complex.

Lavas and dikes may represent precaldera leakage of the magma chamber that subsequently produced the ash-flow eruptions of the Crater Flat Tuff.

Structures may be near the wall of the Prospector Pass caldera segment, postulated source of the Tram Member.

Fault pattern resembles that of resurgent dome; Tram Member of same area has characteristics of intracaldera facies.

Thickest and most welded part of the crater Flat Tuff exposed or penetrated by drill holes Iies adjacent to crater Flat, suggesting a nearby source.

A wedge of monolithologic breccia of the welded part of the Bullfrog, lithologically unlike the exposed Bullfrog, may have been emplaced by collapse of a nearby caldera and sliding from the wall.

Granophyric part of the Bullfrog Member in drill hole appears to be abnormally thick, suggesting a slowly cooled, intracaldera section.

Basalts occur mainly in the moat area of the caldera complex and, as is common in other Great Basin calderas, could have risen along caldera ring fractures.

Pattern of extensional faulting is interrupted by caldera structure. Subsurface data suggest that faulting is not well developed within Crater Flat.

1 A drill hole by U.S. Borax, Inc., about $6.5 \mathrm{~km}$ east of Beatty, and just north of Bare Mountain, penetrated more than $400 \mathrm{~m}$ of Tram Member, underlain by rhyodacitic lava.

Paintbrush Tuff is virtually required by the very thick volcanic section indicated by the gravity anomaly (Snyder and Carr, 1984). Data from two drill holes (USW VH-1 and USW VH-2) in Crater Flat (Carr, 1982; Carr and Parrish, $1985)$ indicate that the subsidence, at least in central Crater Flat, is largely pre-Paintbrush Tuff in age. The subsided area was modified somewhat, mostly by post-Paintbrush Tuff basin-range-style faults, some of which may have partially utilized and reactivated caldera ring fracture faults where these were favorably oriented. This appears especially likely on the east side of Bare Mountain where the trace of the frontal fault zone is curvilinear or gently scalloped. I suspect, but cannot prove, that the en echelon faults that form much of the west margin of Yucca Mountain facing Crater Flat, are reactivated portions of eastern ring fracture faults (fig. 4.4); that is, gently curving and scalloped north-trending caldera ring fracture zones may have responded to east-west crustal extension by collapsing in segments arranged in en echelon fashion. The segments of greatest vertical displacement would correspond in position with the Crater FlatProspector Pass caldera ring-fracture segments. Carr and others (1986, p. 25) suggested that a series of small 10-m.y.old basalt dikes on Yucca Mountain could mark the general location of the buried eastern outer ring fracture zone of the complex (fig. 4.3). As suggested by Snyder and Carr (1984, fig. 5), however, the caldera may be a "trap-door" type, the west side next to Bare Mountain being the area of greatest collapse. If this is correct, the ring fracture zone on the east side of the collapse, next to Yucca Mountain, may have been spread across a wider area and may not have been as well 
Table 4.3. Geophysical evidence of a caldera complex in Crater Flat

\begin{tabular}{|c|c|}
\hline Evidence or feature & Interpretation or comment \\
\hline $\begin{array}{l}\text { Pronounced negative gravity anomaly (nearly } 50 \\
\text { mGal) in Crater Flat. }\end{array}$ & $\begin{array}{l}\text { More than } 4,000 \mathrm{~m} \text { of relatively low-density volcanic } \\
\text { rocks probably are present in Crater Flat (Snyder } \\
\text { and Carr, 1984). }\end{array}$ \\
\hline $\begin{array}{l}\text { Seismic velocities beneath Crater Flat generaliy } \\
\text { agree with gravity anomaly (Hoffman and } \\
\text { Mooney, 1983; Snyder and Carr, 1984). }\end{array}$ & $\begin{array}{l}\text { A very thick section of relatively low velocity rocks, } \\
\text { probably volcanic, underlies crater Flat. }\end{array}$ \\
\hline $\begin{array}{l}\text { Large circular aercmagnetic positive anomaly } \\
\text { centered in southern Crater Flat (Kane and } \\
\text { Bracken, 1983; fig. 4.6). }\end{array}$ & $\begin{array}{l}\text { The unit with magnetic characteristics and thickness } \\
\text { most likely responsible for the anomaly is the } \\
\text { Bullfrog Member; the circular anomaly and relative } \\
\text { nearness (about } 620 \mathrm{~m} \text { ) of the Bullfrog to the surface } \\
\text { at drill hole USW VH-1 (Carr, 1982) suggests a gentle } \\
\text { resurgent dome in the Bullfrog about } 7 \mathrm{~km} \text { in diameter } \\
\text { diameter ( } \mathrm{fig} .4 .6 \text { ). }\end{array}$ \\
\hline $\begin{array}{l}\text { A prominent (more than } 1,500 \mathrm{nT} \text { ) negative } \\
\text { aeromagnetic anomaly between northwestern } \\
\text { Crater Flat and Beatty Hash (Kane and }\end{array}$ & $\begin{array}{l}\text { Anomaly occurs over a thick section of Tram Member that } \\
\text { has intracaldera characteristics, and is faulted in a } \\
\text { pattern resembling part of a resurgent structure. }\end{array}$ \\
\hline $\begin{array}{l}\text { Interruption at the west side of Yucca Mountain } \\
\text { of a persistent east-west aeromagnetic } \\
\text { gradient (Kane and Bracken, 1983). }\end{array}$ & $\begin{array}{l}\text { The magnetic gradient, which is likely due to presence of } \\
\text { the Eleana Formation (largely clastic rocks of } \\
\text { Mississippian age) magnetized by Mesczoic granitic } \\
\text { intrusive rocks (Bath and Jahren, 1984), ends near the } \\
\text { margin of the postulated Prospector Pass caldera } \\
\text { segment. }\end{array}$ \\
\hline
\end{tabular}

developed as on the west. Because of the north-south elongation of the gravity low (Snyder and Carr, 1984) and postulated caldera boundaries, it is possible that the complex is similar to a sector graben, a collapsed linear segment on the flanks of a volcanic edifice. Subsequent formation of the large Timber Mountain-Oasis Valley caldera complex in the area where such a volcanic high might have been located, makes very difficult any reconstruction of the terrane and structure at the time of Crater Flat Tuff eruption.

The closest deep drill hole to the Crater Flat-Prospector Pass caldera structure is USW H-6 (Craig and others, 1983) on the west side of Yucca Mountain (figs. 4.4 and 4.5). This hole penetrated a relatively thin section of Crater Flat Tuff, which rests on about $250 \mathrm{~m}$ of dacitic lavas (Craig and others, 1983). These rocks of intermediate composition are present, but thinner, in several other drill holes on Yucca Mountain to the northeast of USW H-6 (fig. 4.5), and at several other locations around Crater Flat, where they occur beneath both the Tram Member of the Crater Flat Tuff and the Lithic Ridge Tuff. Both the Tram and the Lithic Ridge contain abundant lithic fragments of these lavas. Thus, it is likely that the lavas were extensive in the Crater Flat area prior to eruption of the Crater Flat Tuff.

The above interpretations, together with much suggestive evidence, indicate that a caldera complex related to the Crater Flat Tuff lies directly west of Yucca Mountain, but its exact boundaries and dimensions are not well constrained. That a Crater Flat Tuff caldera is not present in the proposed repository site area on Yucca Mountain is shown by the absence of abrupt thickening of the members of the Crater Flat Tuff in the area, their generally weak to moderate welding, and the lack of slide blocks or debris in the tuffs that might indicate the proximity of an unstable caldera wall.

\section{OTHER VOLCANO-TECTONIC STRUCTURE IN THE YUCCA MOUNTAIN AREA}

The question of whether an older (pre-Tram Member) caldera is present beneath northern Yucca Mountain is difficult to answer. More than $744 \mathrm{~m}$ of lava and tuffs underlie the Tram Member in drill hole USW G-1 (fig. 4.4) (Spengler and others, 1981). Gravity data indicate that more than 4,000 m of tuffs underlie Crater Flat and part of Yucca Mountain (Snyder and Carr, 1984), which places the base of the volcanic rocks at least $2.7 \mathrm{~km}$ below sea level. Therefore, it is evident that some sort of pre-Crater Flat Tuff volcano-tectonic subsidence took place in the northern Yucca Mountain area. Carr and others (1986, p. 27 and fig. 7) suggested that the Paintbrush Canyon fault system may mark the east edge of a pre-Crater Flat caldera or large volcanotectonic sag beneath northern Yucca Mountain (fig. 4.4). These faults coincide in general location with the northeastern edge of a lobe of the prominent gravity low under Yucca Mountain and Crater Flat (Snyder and Carr, 1984). In this concept, the Paintbrush Canyon fault system on the east edge of the older possible caldera would be analogous to the faults on the west side of Yucca Mountain previously suggested as partially reactivated segments of the caldera ring fracture zone of the Crater Flat-Prospector Pass complex. 
Some discussion and reassessment of earlier ideas about the relations between volcanic and structural movements in the region seems to be required by the new surface and subsurface information. Cummings (1968) ascribed the termination of most of the basin-range-style faults at the Timber Mountain caldera ring-fracture zone to the inability of the somewhat decoupled or highly fractured caldera substructure to propagate the faults. Christiansen and others (1965) believed that the termination was due to vertical displacement on the basin-range faults being taken up by the caldera ring fracture zone. They also proposed that the faults were related to broad doming and an associated hingeline that developed preceding Timber Mountain Tuff eruptions and caldera collapse.

Later work (Byers and others, 1976b) has demonstrated that rocks on the rim of Timber Mountain caldera northwest of Yucca Wash are part of a resurgent block of the Claim Canyon cauldron (fig. 4.4), the probable source of the Tiva Canyon Member of the Paintbrush Tuff. The resurgent block was eccentric to the caldera, and uplift occurred along the southern portion of the previously formed caldera outer ring fracture zone. Therefore, most of the "circumferential" faults of Christiansen and others (1965, fig. 2) are part of the complex resurgent dome structure. The hingeline, as earlier proposed (Christiansen and others, 1965), is not a simple arcuate feature related to doming preceding eruption of the Timber Mountain Tuff, but a more irregular and less continuous boundary that trends northwest across Yucca Mountain. Structure contours (Carr, 1984, fig. 30) suggest that the easterly dips are related to the basin-range faults, as stated (Christiansen and others, 1965), but the southeasterly dips in the Paintbrush Tuff in the northeastern part of the Yucca Mountain area probably are a combination of initial dip and perhaps some tilting related to resurgence of the Claim Canyon block. This conclusion is based on the general slope of the Paintbrush Tuff units away from their resurgent source area in a direction that is about $45^{\circ}$ to the northerly striking faults in northern Yucca Mountain (Carr, 1984, fig. 30).

The degree of unconformity between the Rainier Mesa Member of the Timber Mountain Tuff and underlying units, and the age of latest significant faulting, tend to increase in a clockwise arc from east to west, from the southern Shoshone Mountain area (fig. 4.5) across Yucca Mountain to the north end of Crater Flat. There is a good spatial relation of faults with the age of the youngest volcanic rocks in

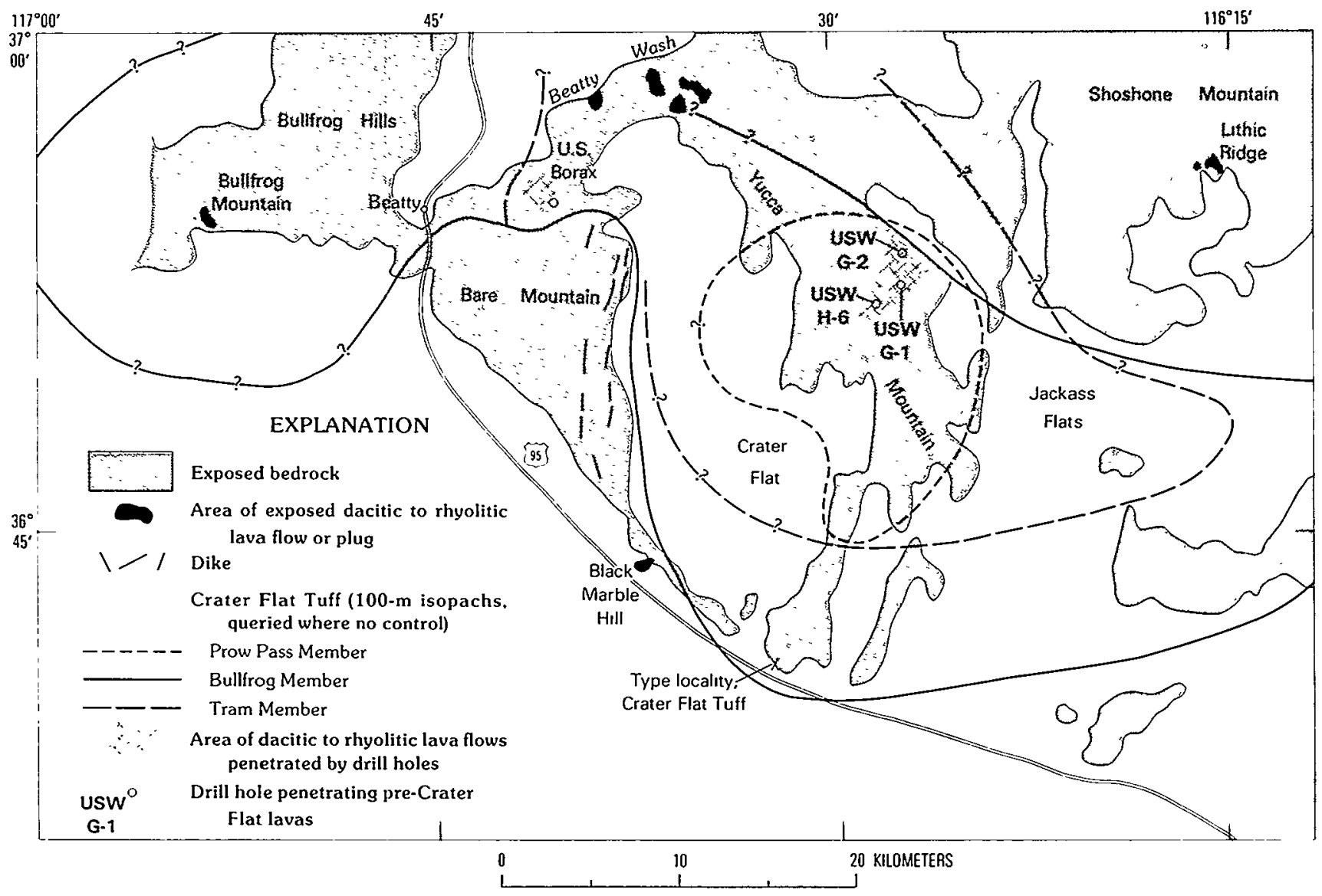

Figure 4.5. Exposed-bedrock and isopach map showing thickness of members of Crater Flat Tuff in southwestern Nevada Test Site. 


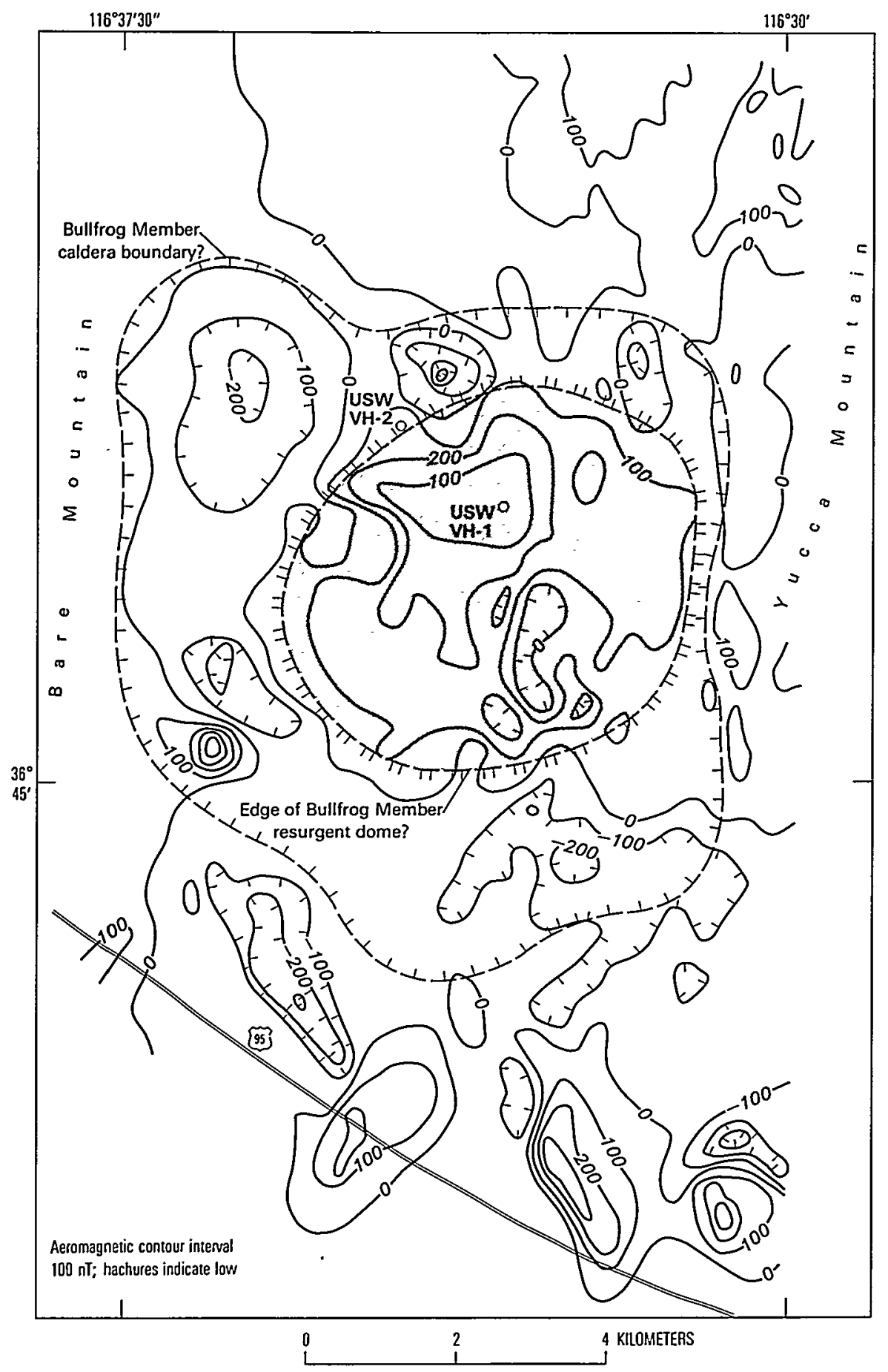

Figure 4.6. Aeromagnetic map of southern Crater Flat area, showing caldera boundary and the proposed resurgent dome (shaded) associated with the Bullfrog Member of the Crater Flat Tuff. From U.S. Geological Survey $(1978,1979)$. Drill holes indicated by small circles.

this arc. On Shoshone Mountain, fault displacements in the Rainier Mesa are commonly nearly as great as those in underlying units (Orkild and O'Connor, 1970); on most of northern Yucca Mountain, the Rainier Mesa Member is absent, but to the south and west it is present at several locations where it was clearly deposited at the foot of pre-existing 
large fault scarps, and later was displaced a minor amount by the north-striking faults. In the northwestern part of Yucca Mountain, the Rainier Mesa Member and precursor lava flows were deposited unconformably across the tilted blocks of the Paintbrush Tuff and older rocks (Byers and others, 1976a), resting on units as old as the Tram Member of the Crater Flat Tuff in the Beatty Wash area northwest of Yucca Mountain (Carr and others, 1986). In the area north of Yucca Wash (fig. 4.4), no Rainier Mesa is present, but the rhyolite lavas of Fortymile Canyon, whose minimum age is about 9.5 m.y., are locally sharply unconformable on the Paintbrush Tuff. (Recent work has demonstrated that most of the rhyolite lavas of Fortymile Canyon were erupted contemporaneously with the Paintbrush and Timber Mountain Tuffs. Thus, faulting in those lavas is a little older than previously thought, and generally the same age as that on Yucca Mountain itself.) The lavas are displaced a moderate amount by the Paintbrush Canyon fault system, which strikes $\mathrm{N}$. $15^{\circ}-20^{\circ} \mathrm{W}$. in the area between Shoshone Mountain and the northeast edge of Yucca Mountain. This faulting is spatially and temporally associated with the area of the youngest voluminous bimodal volcanic eruptions, the rhyolite lavas of Fortymile Canyon, the basalts of Dome Mountain, and the rhyolite of Shoshone Mountain (Byers and others, 1976a). In addition, Fortymile Canyon, near the middle of this zone of faults and young lavas, follows the axis of a structural low that developed after emplacement of the Timber Mountain Tuff (Carr, 1984a, fig. 30). All members of the Paintbrush and Timber Mountain Tuffs, except the Pah Canyon Member of the Paintbrush, thin drastically or are absent in the Fortymile Canyon area, yet the canyon is the site of a pronounced post-Timber Mountain Tuff erosional and structural syncline (Carr, 1984a, fig. 30).

In spite of the tendency for the Timber Mountain Tuff to be faulted in many areas on the rim of the Timber Mountain caldera, the Timber Mountain-Oasis Valley caldera complex in general is not broken by basin-range-style faults of large displacement (Byers and others, 1976a), and the faults that are present show little or no movement in Pliocene or Quaternary time. A similar large decrease in fault activity (Carr, 1984a, tables 4 and 5, p. 84-96) appears to typify most of the Crater Flat-Yucca Mountain area, although minor activity has continued into the Quaternary on a few faults (Swadley and others, 1984).

\section{DEGREE OF LATE CENOZOIC TECTONIC STABILITY OF CRATER FLAT AREA}

Drill holes USW VH-1 and VH-2, together with other geologic and geophysical data, provide evidence that contributes substantially to understanding of the structural history of central Crater Flat during the last $10 \mathrm{~m}$.y. or so. This information was used to produce a cross section (fig. 4.7), which suggests that a relatively small amount of vertical displacement has taken place in central Crater Flat since the late Miocene. Surface exposures show that the basalts a little over $1 \mathrm{~m} . \mathrm{y}$. old, such as the one at Black Cone (fig. 4.7) (Vaniman and others, 1982), and the basalts about $3.8 \mathrm{~m} . y$. old (Vaniman and others, 1982) near USW VH-1 are both at or very near the present surface of Crater Flat. The 1.2-m.y.-old basalts are unfaulted; those about $3.8 \mathrm{~m} . y$. old are cut by a few minor faults. The next oldest closely dated unit penetrated in either drill hole is another basalt at a depth of $360 \mathrm{~m}$ in USW VH-2 (fig. 4.7). As explained elsewhere (Carr and Parrish, 1985) the K-Ar age of 11.2 m.y. obtained for this basalt may be a little too old; the age is probably between 10 and $11 \mathrm{~m} . y$. Assuming an age for the basalt of $11 \mathrm{~m} . y$. , the rate of burial at this location in west-central Crater Flat has been only about $0.03 \mathrm{~m}$ per $1,000 \mathrm{yr}$ (Carr, 1984a, p. 80).

Two important intervals of Paleozoic rock debris were penetrated by USW VH-2, one directly above the Miocene basalt at depths of 309 to $360 \mathrm{~m}$, and the other between the Tiva Canyon Member of the Paintbrush Tuff and the Rainier Mesa Member of the Timber Mountain Tuff, from 535 to $595 \mathrm{~m}$ (fig. 4.7). Most of this material consists of large masses of Paleozoic rocks that have the continuity and texture of gravity slide blocks. The upper zone, just above the basalt, is in the same stratigraphic position as an extensive (at least $7 \mathrm{~km}$ across) slide mass of lower Paleozoic rocks exposed along the south rim of Crater Flat (fig. 4.3). This nearly continuous mass of Paleozoic rock rests on basalt dated at 10.5 m.y. (R.J. Fleck, U.S. Geological Survey, written commun., 1978) that is very similar to the basalt in the USW VH-2 drill hole. Thus, much of southern and western Crater Flat was covered by large masses that probably slid from high terrane on or near Bare Mountain, possibly as the result of ground motion from nearby large earthquakes. This slide mass is cut by only a few small faults, and at the southeast corner of Black Marble hill where the large frontal fault zone at the east foot of Bare Mountain crosses into the Amargosa Desert valley (fig. 4.3), very little vertical movement appears to have occurred after emplacement of the slide (Swadley and Carr, in press). The exact age of the slide is not known; it is younger than $10.5 \mathrm{~m} . \mathrm{y}$. and older than the $3.8-\mathrm{m}$.y.-old basalts in the southeastern part of Crater Flat. Thus, emplacement of the slide, or slides, may coincide with the last major movements on the east frontal fault of Bare Mountain. The older interval of Paleozoic rock debris in USW VH-2 between the Tiva Canyon and Rainier Mesa Members corresponds in stratigraphic position with the time of major faulting at Yucca Mountain, and suggests that the Bare Mountain frontal fault was also active at about the same time.

No faults of large displacement were encountered in either USW VH-1 or VH-2. The apparent absence of largedisplacement north-trending faults, especially in central and western Crater Flat, is consistent with geophysical data. Except for the major fault at the foot of Bare Mountain, gravity data (Snyder and Carr, 1984) do not indicate any important buried faults of northerly strike, nor do low-level 


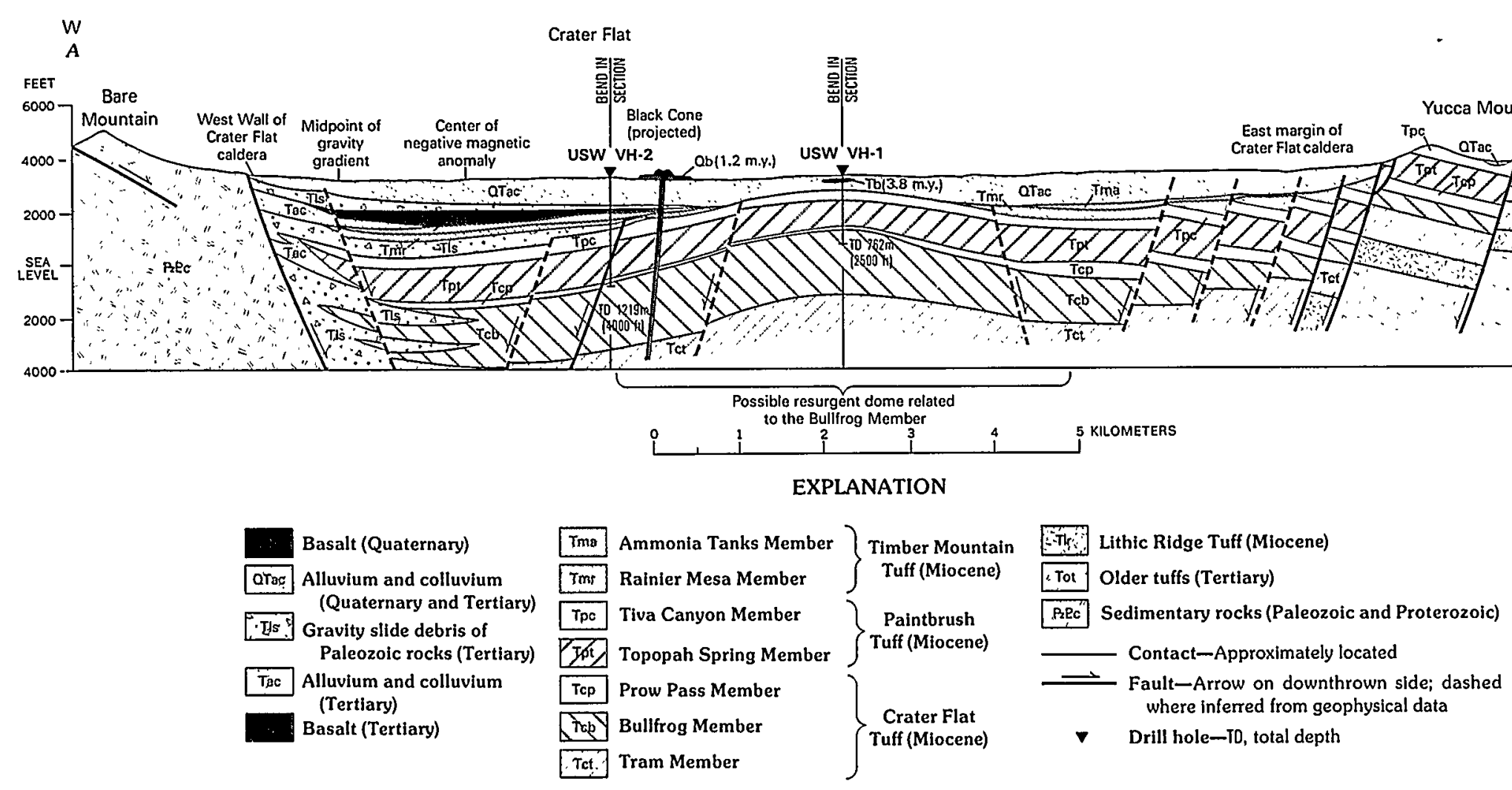

등 Figure 4.7. Cross section of Crater Flat between Bare Mountain and Yucca Mountain. Doming at drill hole USW VH-1 is inferred from the relatively shallow position of the tuffs and from geophysical evidence. See figure 4.3 for section location. 
aeromagnetic data (Kane and Bracken, 1983), which show very well the exposed prominent faults on Yucca Mountain.

The rate of burial or tectonic adjustment at USW VH-2 during about the last $11 \mathrm{~m} . \mathrm{y}$. has been estimated at 0.03 $\mathrm{m} / 1,000 \mathrm{yr}$ (Carr, 1984, table 2). The complete absence of volcanic debris in the Tertiary and Quaternary alluvium and rock debris below about $120 \mathrm{~m}$ depth in USW VH-2 suggests that there was no large structural tilting to the west during deposition of that part of the stratigraphic record. Assuming that the correct age of the basalt is about $10.5 \mathrm{~m} . \mathrm{y}$., at USW VH- 2 only about $365 \mathrm{~m}$ of alluvium and slide material has accumulated in that time, two-thirds of it $(245 \mathrm{~m})$ before the influx of volcanic clasts from the east began. Interpolation, using a uniform deposition rate, suggests that the change in deposition from entirely Paleozoic rock debris to mainly volcanic fragments took place about $3.5 \mathrm{~m}$.y. ago. The presence of basalt a little more than $1 \mathrm{~m}$.y. old at the surface at nearby Red Cone and Black Cone (fig. 4.1) suggests a significant slowing of the alluviation process and (or) stabilization of tectonic adjustments in at least the last $1 \mathrm{~m} . \mathrm{y}$. or so. If the incorporation of volcanic clasts in the alluvium began roughly 3-4 m.y. ago, the cause could have been gentle westward tilting that accompanied renewed displacement on the Bare Mountain frontal fault zone. Conversely, the ending of significant uplift of Bare Mountain could have slowed the accumulation of fans of Paleozoic rock debris, and allowed encroachment of volcanic clasts from the east. The cross section of figure 4.7 assumes the latter explanation, and allows only minor structural tilting after the Tertiary basalts were extruded.

Although the steep, morphologically youthfulappearing east front of Bare Mountain is obviously the locus of persistent faulting, the lack of large-scale downdropping of post-tuff units (basalt and alluvium) in central and eastern Crater Flat is good evidence that no major structural displacement has occurred in most of Crater Flat during the last 10 m.y. or so. As mentioned previously, the overlap and onlap of large fault scarps in the Paintbrush Tuff by the Rainier Mesa Member around the flanks of Yucca Mountain (Scott and Bonk, 1984) also demonstrate the age of the major faulting. There are, however, indications that each basalt eruptive episode in and near Crater Flat was accompanied by some faulting. The most obvious relation was found in two trenches dug across faults in eastern Crater Flat near Yucca Mountain, where basalt ash, probably related to the 1.2-m.y. episode of basalt eruption (Swadley and others, 1984), was found at several meters depth within the faults (Swadley and Hoover, 1983). Large-scale landslides, possibly triggered by faulting and earthquakes, appear to be closely associated in time with the 3.8-m.y.- and 10 to 11-m.y.-old basalt episodes. Some or all of the youngest minor surface faulting in the Crater Flat-Yucca Mountain area may have accompanied the Big Dune basalt eruption (approximately $0.27 \mathrm{~m} . \mathrm{y}$. ago) (fig. 4.3). This faulting, of less than $1 \mathrm{~m}$ displacement, was estimated by Swadley and Hoover (1983) to have occurred between 260,000 and 40,000 years ago, with the evidence favoring the older part of this range, which places it at the general time of the Big Dune basalt eruption.

\section{CONCLUSIONS}

Structural development of most of the Crater FlatYucca Mountain area was closely related to volcano-tectonic processes, which probably included magmatic insurgent and resurgent doming, possible sector grabens or elongate sags, and caldera collapse, but the mechanisms are complex and not completely understood. Incontrovertible proof of calderas beneath Crater Flat and part of Yucca Mountain would require deep drill holes.

Clearly, the youngest significant tectonic adjustments occurred in the areas of the youngest volcanic eruptions, but considerable evidence indicates that Crater Flat itself is mainly a relatively old (middle Miocene) volcano-tectonic depression, and probably a caldera complex, that has not been greatly modified by subsequent Pliocene or Quaternary tectonic activity. Important faulting that displaced the Paintbrush Tuff after Crater Flat caldera formation may have been controlled, in part, by reactivation of buried caldera ring fractures of favorable northerly trend near the east and west caldera margins, specifically the curvilinear fault at the east foot of Bare Mountain, and several en echelon faults distributed across western and northwestern Yucca Mountain. Subsequent faulting, though relatively minor in most areas, was spatially and temporally related to the late Miocene bimodal and younger basaltic volcanism. The timing and trend of past tectonic events, however, suggests relative stability for the Crater Flat-northern Yucca Mountain area in the future.

\section{REFERENCES CITED}

Bath, G.D., and Jahren, C.E., 1984, Interpretation of magnetic anomalies at a potential repository site located in the Yucca Mountain area, Nevada Test Site: U.S. Geological Survey Open-File Report 84-120, 40 p.

Byers, F.M., Jr., Carr, W.J., Christiansen, R.L., Lipman, P.W., Orkild, P.P., and Quinlivan, W.D., 1976a, Geologic map of the Timber Mountain caldera area, Nye County Nevada: U.S. Geological Survey Miscellaneous Investigations Series Map I-891; scale $1: 48,000$.

Byers, F.M., Jr., Carr, W.J., Orkild, P.P., Quinlivan, W.D., and Sargent, K.A., 1976b, Volcanic suites and related cauldrons of Timber Mountain-Oasis Valley caldera complex, southern Nevada: U.S. Geological Survey Professional Paper 919, 70 p.

Carr, W.J., 1982, Volcano-tectonic history of Crater Flat, southwestern Nevada, as suggested by new evidence from drill hole USW-VH-1 and vicinity: U.S. Geological Survey Open-File Report 82-457, 23 p.

1984a, Regional structural setting of Yucca Mountain, southwestern Nevada, and late Cenozoic rates of tectonic 
activity in part of the southwestern Great Basin, Nevada and California: U.S. Geological Survey Open-File Report 84-854, $109 \mathrm{p}$.

1984b, Timing and style of tectonism and localization of volcanism in the Walker Lane belt of southwestern Nevada [abs.]: Geological Society of America, Abstracts with Programs, v. 16, no. 6, p. 464.

Carr, W.J., Byers, F.M., Jr., and Orkild, P.P., 1986, Stratigraphic and volcano-tectonic relations of Crater Flat Tuff and some older volcanic units, Nye County, Nevada: U.S. Geological Survey Professional Paper 1323, 28 p.

Carr, W.J., and Parrish, L.D., 1985, Geology of drill hole USW VH-2 and structure of Crater Flat southwestern Nevada: U.S. Geological Survey Open-File Report 85-475, 41 p.

Christiansen, R.L., Lipman, P.W., Orkild, P.P., and Byers, F.M., Jr., 1965, Structure of the Timber Mountain caldera, southern Nevada, and its relation to basin-range structure: U.S. Geological Survey Professional Paper 525-B, p. B43-B48.

Christiansen, R.L., Lipman, P.W., Carr, W.J., Byers, F.M., Jr., Orkild, P.P., and Sargent, K.A., 1977, Timber Mountain-Oasis Valley caldera complex of southern Nevada: Geological Society of America Bulletin, v. 88, p. 943-959.

Craig, R.W., Reed, R.L., and Spengler, R.W., 1983, Geohydrologic data for test well USW H-6, Yucca Mountain area, Nye County, Nevada: U.S. Geological Survey Open-File Report 83-856, $35 \mathrm{p}$.

Cummings, David, 1968, Mechanical analysis of the effect of the Timber Mountain caldera on basin and range faults: Journal of Geophysical Research, v. 73, no. 8, p. 2787-2794.

Hoffman, L.R., and Mooney, W.D., 1983, A seismic study of Yucca Mountain and vicinity, southern Nevada: Data report and preliminary results: U.S. Geological Survey Open-File Report 83-588, $57 \mathrm{p}$.

Kane, M.F., and Bracken, R.E., 1983, Aeromagnetic map of Yucca Mountain and surrounding regions, southwest Nevada: U.S. Geological Survey Open-File Report 83-616, 19 p.; scale $1: 48,000$.

Lipman, P.W., and McKay, E.J., 1965, Geologic map of the Topopah Spring SW quadrangle, Nye County, Nevada: U.S. Geological Survey Geologic Quadrangle Map GQ-439; scale 1:24,000.

Noble, D.C., Sargent, K.A., Mehnert, H.H., Ekren, E.B., and Byers, F.M., Jr., 1968, Silent Canyon volcanic center, Nye County, Nevada, in Nevada Test Site, Eckel, E.B., ed.: Geological Society of America Memoir 110,p. 65-75.
Orkild, P.P., and O'Connor, J.T., 1970, Geologic map of the Topopah Spring quadrangle, Nye County, Nevada: U.S. Geological Survey Geologic Quadrangle Map GQ-849, scale 1:24,000.

Rogers, A.M., Harmsen, S.C., Carr, W.J., and Spence, W.J., 1983, Southern Great Basin seismological data report for 1981, and preliminary data analysis: U.S. Geological Survey OpenFile Report 83-669, 240 p.

Scott, R.B., and Bonk, Jerry, 1984, Preliminary geologic map of Yucca Mountain, Nye County, Nevada, with geologic sections: U.S. Geological Survey Open-File Report 84-494; scale $1: 12,000$.

Scott, R.B., and Castellanos, Mayra, 1984, Stratigraphic and structural relations of volcanic rocks in drill holes USW GU-3 and USW G-3, Yucca Mountain, Nye County, Nevada: U.S. Geological Survey Open-File Report 84-491, 121 p.

Snyder, D.B., and Carr, W.J., 1984, Interpretation of gravity in a complex volcano-tectonic setting, southwestern Nevada: Journal of Geophysical Research, v. 89, no. B12, p. 10,193-10,206.

Spengler, R.W., Byers, F.M., Jr., and Warren, J.B., 1981, Stratigraphy and structure of volcanic rocks in drill hole USWG1, Yucca Mountain, Nye County, Nevada: U.S. Geological Survey Open-File Report 81-1349, 50 p.

Swadley, W C, and Carr, W.J., 1987, Geologic map of the surficial and Tertiary rocks of the Big Dune quadrangle, California and Nevada: U.S. Geological Survey Miscellaneous Investigations Series Map I-1767; scale 1:48,000.

Swadley, W C, and Hoover, D.L., 1983, Geology of faults exposed in trenches in Crater Flat, Nye County, Nevada: U.S. Geological Survey Open-File Report 83-608, 15 p.

Swadley, W C, Hoover, D.L., and Rosholt, J.N., 1984, Preliminary report on late Cenozoic faulting and stratigraphy in the vicinity of Yucca Mountain, Nye County, Nevada: U.S. Geological Survey Open-File Report 84-788, 42 p.

U.S. Geological Survey, 1978, Aeromagnetic map of Lathrop Wells area, Nevada: U.S. Geological Survey Open-File Report .78-1103; scale 1:48,000.

1979, Aeromagnetic map of the Timber Mountain area, Nevada: U.S. Geological Survey Open-File Report 79-587; scale 1:48,000.

Vaniman, D.T., Crowe, B.M., and Gladney, E.S., 1982, Petrology and geochemistry of hawaiite lavas from Crater Flat, Nevada: Contributions to Mineralogy and Petrology, v. 80, p. 341-357. 



\title{
5. Detachment Faulting in the Death Valley Region, California and Nevada
}

\author{
By Warren B. Hamilton
}

\section{CONTENTS}

\section{Abstract $\mathbf{5 1}$}

Introduction $\mathbf{5 1}$

Bare Mountain, Bullfrog Hills, Funeral Mountains, and Yucca Mountain 53

Bare Mountain detachment fault $\mathbf{5 3}$

Bullfrog Hills detachment fault $\mathbf{5 5}$

Funeral Mountains detachment fault 57

Continuity of faulting between Bare Mountain, Bullfrog Hills, and the Funeral Mountains 59

Imbricate faulting of Yucca Mountain 62

Black Mountains 62

Amargosa detachment fault and Amargosa chaos 62

Turtleback detachment faults 65

Upper-plate normal faults 65

Continuity of faulting in Black Mountains 67

Relation between detachment faults of the Black and Funeral Mountains 67

Panamint Mountains 68

Hanaupah detachment fault 68

Tucki detachment-fault system 69

Central Panamint Mountains 71

Opening of Death Valley $\mathbf{7 2}$

Northern Death Valley $\mathbf{7 3}$

Central Death Valley 73

COCORP seismic-reflection profiles 77

Opening of Panamint Valley $\mathbf{7 7}$

Extension west of Panamint Valley 78

Extension south of the Death Valley region 78

Extension east of the Death Valley region 78

Discussion 79

References cited $\mathbf{8 2}$

\section{Abstract}

Detachment faults of Oligocene to Holocene age are widely exposed in the Death Valley region, where crustal extension is interpreted to have amounted to at least 100 percent and is continuing at a high rate. Upper-crust fault blocks of both preextensional and synextensional materials, rotated to consistent eastward dips, and the west-dipping normal faults that separate and dismember them, all end downward at undulating detachment faults in the Panamint, Black, and Funeral Mountains, Bare Mountain, and the Bullfrog Hills. Beneath the detachment faults are rocks that were in the middle crust before extension, and thick ductile shear zones were developed during early, deep slip on the structures. The detachment faults may represent great normal faults that initially dipped westward but that have been rotated and raised as tectonic denudation unroofed them progressively westward. The huge upper-plate blocks of the Grapevine and southern Funeral Mountains were stranded atop raised and flattened sectors of the faults, whereas the upper-plate blocks of the Panamint and Cottonwood Mountains continue to slip away. Synextensional basin-fill materials compose half the width of upper plates at the detachments; panels of pre-Tertiary rocks were not in contact with one another above detachments except during early stages of extension. Although very late slip on near-surface domiform detachment faults is down dip into widening basins, earlier slip was regionally westward and northwestward, independent of present directions of dip of the detachment surfaces.

In the southern Great Basin, extension farthest west has taken place during Pliocene and Quaternary time, that farthest east took place mostly in the middle Miocene; and a broad medial tract was extended during late Oligocene and early Miocene time, with a westward younging of termination of major extension-middle Miocene in the Nevada Test Site, late Miocene in the Bullfrog Hills, Pliocene in the Funeral Mountains, and still active in Death Valley. The imbricate middle Miocene faulting of Yucca Mountain represents the headwall position of the Bare Mountain-Bullfrog Hills-Funeral Mountains detachment system when the part of the original fault to the east had risen so that further slip there was precluded but when the part to the west still dipped westward.

Middle Tertiary extension was approximately westward, relative to the continental interior, and this produced northtrending fault blocks. Late Neogene extension has been northwestward, and the old blocks, with their inherited trends, are being carried obliquely apart. The present east limit of major deformation is along the east side of Death Valley and is marked by northwest-trending right-slip faults in the north and south and by oblique-slip north-trending normal faults between them.

\section{INTRODUCTION}

The width of the Basin and Range province has been about doubled by crustal extension during middle and late Cenozoic time. The sort of structures on which this deformation has been accomplished are exposed particularly well in the Death Valley region (fig. 5.1), where rapid extension is continuing. This chapter describes and interprets the extensional structures of that region and, to a lesser extent, surrounding regions. Many of these interpretations are controversial. For a regional synthesis with conclusions broadly incompatible with those presented here, see Carr (1984). 
Yucca Mountain, in the southwest part of the Nevada Test Site and the northeast corner of the Death Valley region (see fig. 5.2), is being considered as a repository for radioactive waste. An understanding of the late Cenozoic structure of the region is needed for evaluation of the deep geometry of the site and of the possible ground motions and disruptions that might accompany earthquakes. Neogene structures are exposed within the test site only at upper crustal levels. They are largely middle Miocene in age and consist mostly of normal faults, with steep to moderate dips, between gently rotated blocks. Moderate extension of the upper crust is required by this geometry, but far more extension took place in early Miocene and late Oligocene time. Extensional structures of the sort that originated within the middle crust and that are likely to lie deep beneath Yucca Mountain are exposed widely in the Death Valley region.

Exposures are excellent in Death Valley and vicinity, where altitudes are near sea level, but mediocre closer to the test site, where altitudes are typically near $1,000 \mathrm{~m}$. Compare the many photographs, presented in this chapter, of detachment faults exposed superbly at low altitudes with the two photographs (figs. $5.3 B, 5.4 C$ ) of detachment faults exposed poorly at altitudes of about $1,000 \mathrm{~m}$. Exposures are still poorer in much of the test site itself and throughout most of the Great Basin. Because structures of the type displayed so well in Death Valley are likely to be present much more

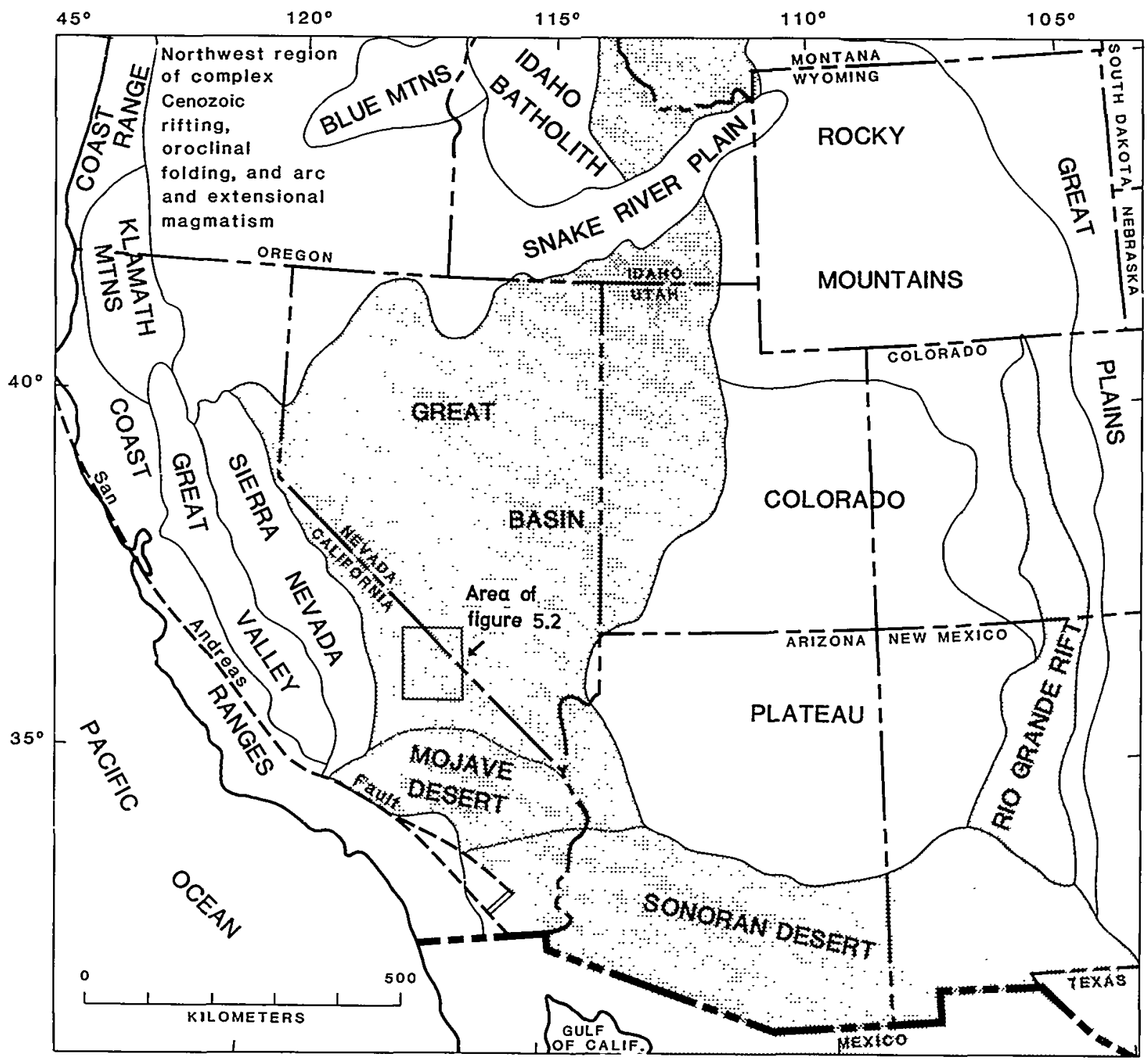

Figure 5.1. Physiographic provinces of the Western United States. Basin and Range province (shaded) of middle and late Cenozoic extensional faulting consists of the Great Basin and the Mojave and Sonoran Deserts. Regions of similar deformation in the Rio Grande Rift and north of the Snake River Plain are also shaded. 
widely in the Great Basin than has been generally recognized, I have included many photographs of them as possible guides to relations that might be sought elsewhere.

Studies in many parts of the Basin and Range province, including the Death Valley region, have demonstrated that severe extension incorporates detachment faulting. A detachment fault is a major undulating or gently dipping extensional fault that attenuates a crustal section. The term has been used in this context by G.A. Davis (Davis and others, 1980) and many others. The terms "denudation fault" (Armstrong, 1972) and "decollement" (Miller and others, 1983, as used in an extensional context only) are synonyms of detachment fault. The origin of these structures is much debated.

Early geologists in the Death Valley region were at the forefront of interpretations of extensional geology. Emmons (1907) and Emmons and Garrey (1910) mapped a detachment fault and recognized the extensional nature of normal faulting half of a century ahead of most Basin and Range geologists. The so-called chaos and turtleback features described by Curry (1954), Noble (1941), and others from Death Valley can now be placed in the framework of great extensional deformation. Hunt and Mabey (1966) were first to recognize a complete domiform detachment fault, the Tucki Mountain fault in the Panamint Mountains, as being of extensional origin. Hamilton and Myers (1966) discussed the region and reached the then-outrageous conclusion that Cenozoic extension had doubled the width of the Great Basin. Stewart (1983) recognized that the great upper-plate block of the Panamint Mountains had moved completely over the Black Mountains lower plate. Much of the mapping of the last several decades in the Black and Funeral Mountains has been done by L.A. Wright and B.W. Troxel (Wright and Troxel, 1973, 1984; Wright and others, 1974), who have emphasized extensional explanations but have interpreted exposed structures largely in terms of imbricate normal faulting related to deeply hidden detachment faults. Work underway by B.C. Burchfiel, B.P. Wernicke, and others is focused on exposed detachment faults.

My work in the Death Valley region consists of widespread reconnaissance, which provides a basis for interpretation of mapping published by other geologists. I brought to the region biases developed in the course of my work in southeastern California and my contacts with many other geologists working with detachment faults in that region; among those to whom I am indebted for comprehension of these structures are G.A. Davis, G.H. Davis, K.A. Howard, Barbara John, and S.J. Reynolds. I developed from geologicmap and seismic-reflection data the interpretation (Hamilton, $1982,1987)$ that the middle crust is extended primarily by the sliding apart of lenses separated by zones of ductile shear, that the upper crust is broken into rotated blocks in response to the widening of the composite top of these separating lenses, and that most detachment faults are the tops of these lenses. A contrary model was developed by B.P. Wernicke (1985), who argued that master normal faults cut through the entire crust at gentle to moderate angles, that isostatic rise carries these faults toward the surface as they are denuded tectonically, and that detachment faults are primarily exposures of such master normal faults. Although in my 1987 paper I continued to argue for the broad applicability of the crustal-lens model, in this paper I instead accept much of Wernicke's model as applicable to upper-crustal deformation; I retain the crustal-lens model for much middle-crustal deformation. An extensive fieldtrip with Wernicke in early 1987 convinced me of the validity of much of his interpretation. I return to the subject of crustal mechanics in this paper after describing the structural geology. All photographs here are my own, and their lengthy captions are intended to augment the brief generalizations in the text.

The southwestern part of the Great Basin, which includes the Death Valley region, is the most actively extending part of the Basin and Range province. Within the area shown in figure 5.2, or near it to the west and northwest, are the highest steep scarps, the most severe deformation of Quaternary materials, the deepest topographic closures of structural depressions, and the youngest exposed detachment faults. Indeed, some gently dipping detachment faults exposed at the surface are still active. Nonresistant Neogene upper-plate materials are widely preserved above the detachments, and late Quaternary valley fill hides much less structure than in less active regions. Also shown in figure 5.2 are detachment faults that are exposed in the Panamint, Funeral, and Black Mountains, Bare Mountain, and the Bullfrog Hills. The Argus and Greenwater Ranges and the Cottonwood and Grapevine Mountains display only upperplate materials but must be underlain by detachment faults at shallow depth.

The following discussion proceeds in a general way from east to west within the Death Valley region, and thus from areas in which there is little active faulting to areas of great young activity.

\section{BARE MOUNTAIN, BULLFROG HILLS, FUNERAL MOUNTAINS, AND YUCCA MOUNTAIN}

The farthest northeast exposed detachment fault of the Death Valley region is that of Bare Mountain and the Bullfrog Hills, which is now inactive. This Bare Mountain detachment fault projects eastward beneath Yucca Mountain. The detachment faults exposed in Bare Mountain, the Bullfrog Hills, and the Funeral Mountains appear to be domiform exposures of a single fault surface that initially dipped westnorthwestward and was denuded as the Grapevine Mountains upper-plate block slid down it.

\section{Bare Mountain Detachment Fault}

The lower plate of the Bare Mountain detachment fault, which consists of variably metamorphosed Late Proterozoic and Cambrian strata, has been much extended internally by normal faults that now mostly dip gently (Cornwall and 


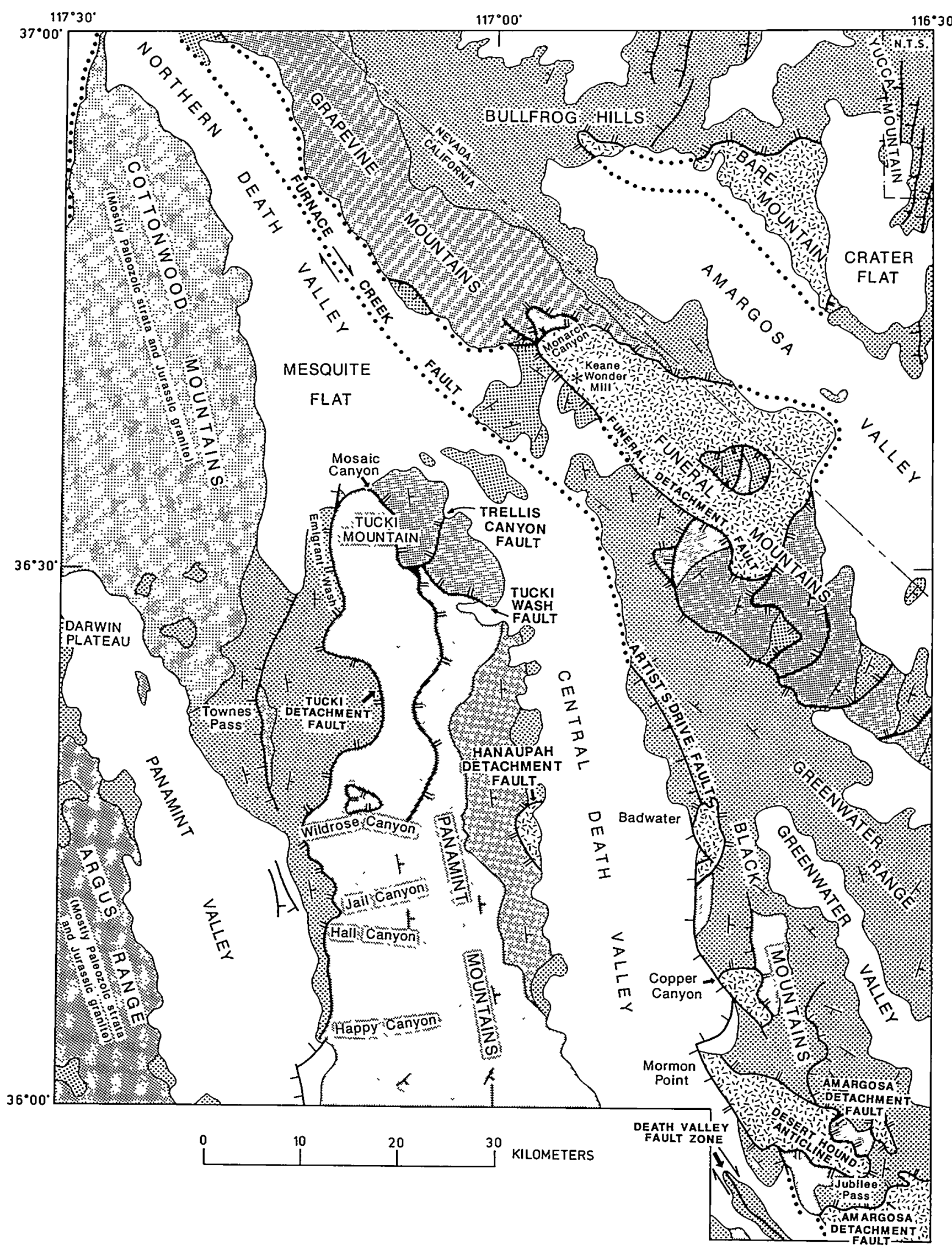

54 Geologic and Hydrologic Investigations, Yucca Mountain, Nevada 
Kleinhampl, 1961, who regarded the Neogene faults as thrust faults; Cornwall, 1972; Monsen, 1982; M.D. Carr and S.A. Monsen, oral commun., 1985, 1986). Metamorphism of the lower-plate rocks increases gradually from lowest greenschist facies in the far south (slaty pelites, nonmarbleized carbonates: my observations) to lower amphibolite facies in the northwest (staurolite + garnet, epidote + hornblende: Monsen, 1982; T.D. Hoisch, oral commun., 1987).

Upper-plate rocks have been stripped from most of the Bare Mountain lower plate but are preserved in the south and north. At the south end of Bare Mountain, nonmetamorphosed Cambrian strata are truncated downward against the gently plunging detachment fault (fig. 5.3A). Middle Miocene ashflows, about $11 \mathrm{~m} . y$. old, and slide megabreccia lie upon the southern upper-plate Cambrian rocks and are but gently tilted (Swadley and Carr, 1987). Around the north end of Bare Mountain, upper middle Miocene volcanic rocks, older than about 11.2 m.y., dip downward to truncations against the detachment fault (fig. 5.3B), whereas lower upper Miocene volcanic and sedimentary rocks about $10.5 \mathrm{~m} . \mathrm{y}$.

\section{EXPLANATION}

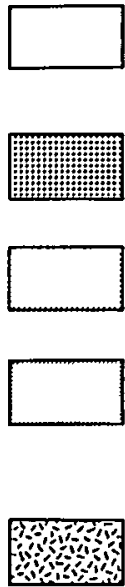

Quaternary materials

\section{UPPER-PLATE ROCKS}

Tertiary, sedimentary and volcanic rocks, Oligocene through Pliocene

Paleozoic, includes Mesozoic granitic rocks

Precambrian, Middle Proterozoic plutonic rocks and Late Proterozoic sedimentary and metasedimentary rocks

\section{LOWER-PLATE ROCKS}

Metamorphic and plutonic rocks, of diverse ages, below lowest exposed faults

\section{Faults, dotted where concealed}

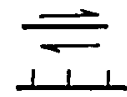

Strike-slip, arrows indicate relative movement

Normal, hachured on downthrown side

넨 Detachment faults and normal faults rotated to gentle dips, hachures on upper plate

\section{$\perp$ Strike and dip of inclined strata}

Figure 5.2. Tectonic and generalized geologic map of Death Valley region, California and Nevada. Most normal faults are omitted. Adapted mostly from published maps cited in text. See figure 5.1 for location. old and younger lie unconformably across both the fault and the deformed upper-plate volcanic rocks and are merely tilted (Florian Maldonado and P.P. Orkild, oral commun., 1985, 1987; compare Carr, 1984). Breccia of unmetamorphosed Cambrian and Late Proterozoic rocks locally intervene between upper and lower plates (fig. 5.3B) and attest to the earlier passage across the lower plate of an upper plate of Paleozoic strata, presumably that of the present Grapevine Mountains. The time of inception of faulting is not defined by local data, but in the Grapevine Mountains (discussed below), which likely slid westward from above Bare Mountain, extension probably was underway in late Oligocene time. The faulting about 11 m.y. ago represents only the last slip on the detachment fault, which thus had a history that predates also the faulting of Yucca Mountain.

Although Bare Mountain is deeply eroded, its crest and lateral ridges define a symmetrical domiform surface which plunges northward and southward to approximately become the exposed detachment fault, and hence likely has been but little eroded beneath the detachment fault elsewhere. This surface dips under upper Quaternary alluvium on both the east (fig. 5.3A,C) and west sides of the range, where there are no exposures of upper-plate rocks. A steep range-front fault was inferred by Carr (1984), Cornwall (1972), and Cornwall and Kleinhampl (1961) to bound the east side of Bare Mountain. M.C. Reheis (chapter 8) found evidence for local disruption of alluvium at the foot of the range and inferred that steep faulting has broken the front within Holocene time.

The absence of range-front scarps in either bedrock or surficial materials (fig. 5.3A, C) is strong evidence against the presence of a young range-front fault at the east base of Bare Mountain. The surface defined by the crests of the lateral ridges projects smoothly beneath the alluvium of Crater Flat with a dip of about $30^{\circ}$. The continuation of that surface beneath the alluvium with about that inclination is demonstrated by detailed gravity traverses across the range front (Snyder and Carr, 1982). No gravity gradient is present as would be if a steep fault was at the foot of the bedrock exposures. Farther east under Crater Flat, a steeper subsurface contact at considerable depth can be fitted to ambiguous gravity models but is not required. Carr (1984), Carr and others (1986), and Snyder and Carr (1982, 1984) inferred two Miocene calderas to lie beneath Crater Flat, but facies and distribution of Miocene ignimbrites require no ignimbrite sources in this area, and the gravity analysis by Snyder and Carr is in my view merely a visual aid in support of permissive rationales for such calderas.

\section{Bullfrog Hills Detachment Fault}

The detachment fault of the Bullfrog Hills, west of northern Bare Mountain, has an upper plate of Miocene volcanic and sedimentary rocks, as young as $7.5 \mathrm{~m} . y$. old, which dip moderately to steeply eastward and northeastward 


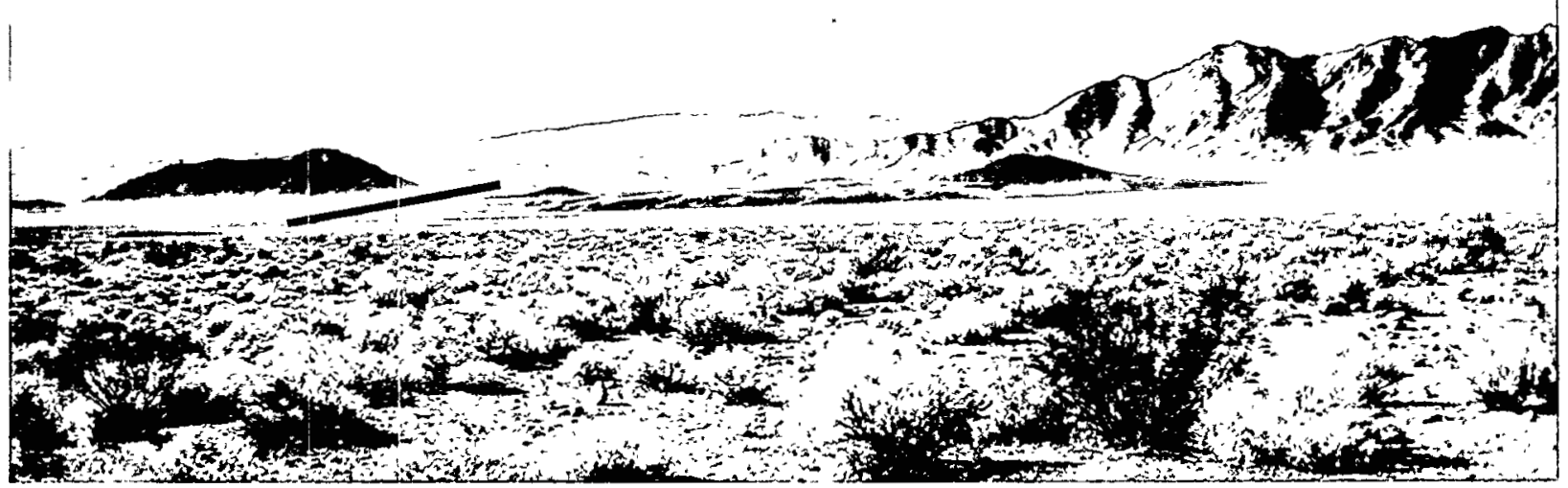

$A$

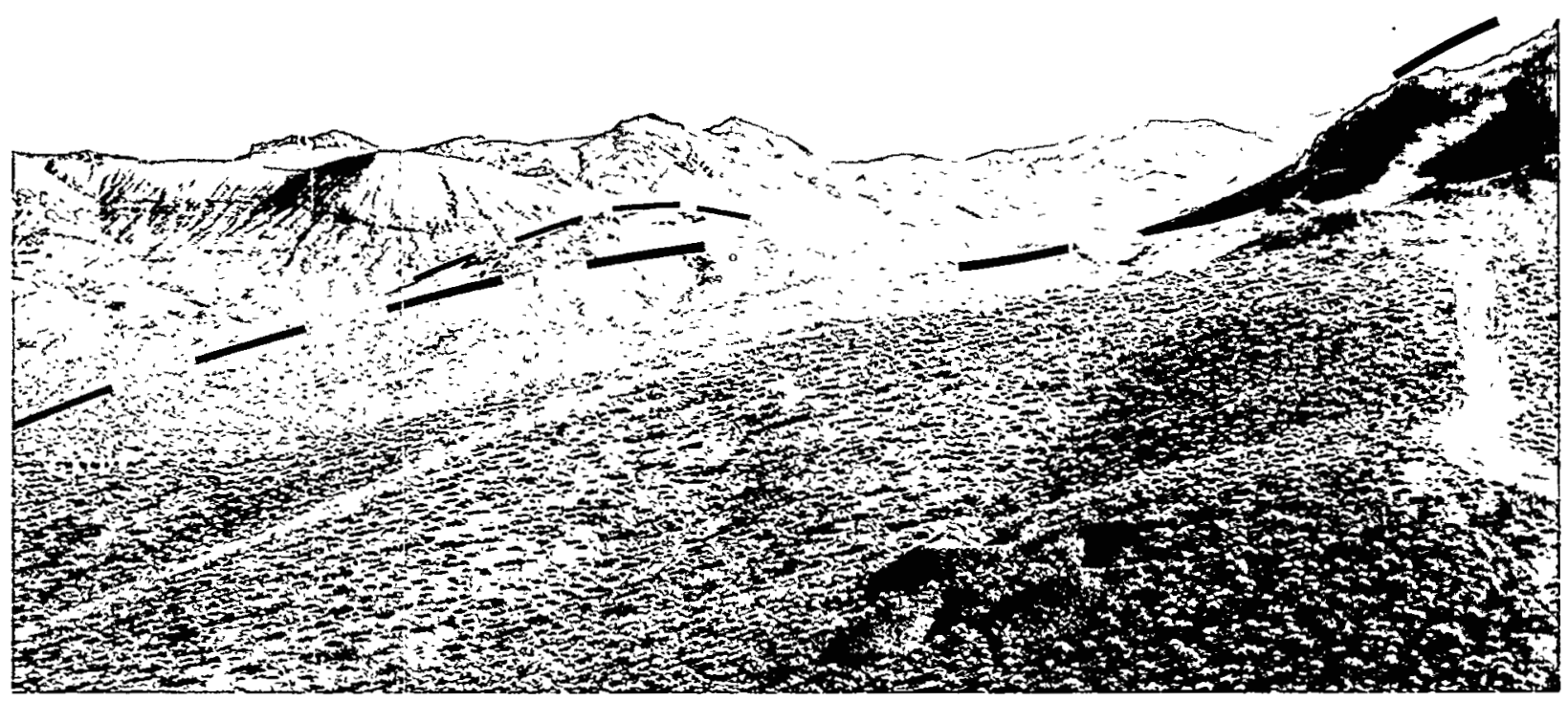

$B$

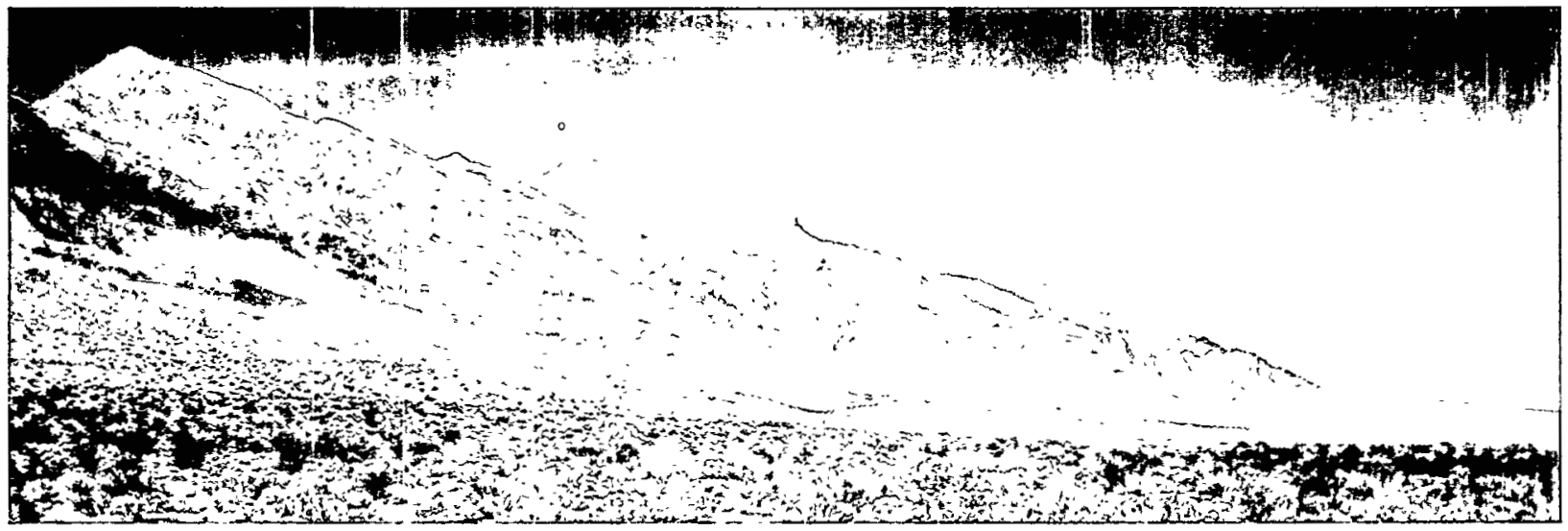

C 
to a truncation against the poorly exposed fault, which defines a gentle north-plunging dome (Florian Maldonado, written commun., 1985; Cornwall and Kleinhampl, 1964; Emmons and Garrey, 1910). Faulting continued later here than in Bare and Yucca Mountains nearby to the east but is now inactive or nearly so.

The Bullfrog lower plate consists of Late Proterozoic strata metamorphosed at amphibolite facies, including staurolite-kyanite assemblages (T.D. Hoisch, oral commun., 1987), Jurassic(?) pegmatite, and variably mylonitized undated gneiss. Between the upper and lower plates is a sheet of slightly metamorphosed and much disrupted Paleozoic strata, analogous to the carapaces seen on many other detachment faults in the region and formed presumably as a friction breccia beneath the Grapevine Mountains block as it slid over the Bullfrog lower plate.

\section{Funeral Mountains Detachment Fault}

What I regard as a continuous domiform Funeral Mountains detachment fault with an elliptical trace was mapped as many separate faults of diverse types by Giaramita (1984, who recognized its continuity around the north end of the complex), Hunt and Mabey (1966), McAllister (1971), Swadley and Carr (1987), and L.A. Wright and B.W. Troxel (written commun., 1986, unpublished map; see also Labotka, 1980, and Labotka and Albee, in press). The lower plate has a domiform upper surface both where the upper plate is preserved and where it has been stripped away (fig. 5.4).

Lower-plate rocks are metamorphosed clastic strata, and subordinate carbonate rocks, that are at least mostly Late

Figure 5.3. Bare Mountain detachment fault. The last important slip on this fault occurred about $11 \mathrm{~m}$.y. ago. A, View southwest to south end of Bare Mountain. Detachnient fault (line on left; the right skyline is eroded little beneath the fault) separates Middle or Upper Cambrian limestone and dolomite (dark hill on left) from low-grade-metamorphic Late Proterozoic clastic rocks (rest of range to right). Upper plate slipped obliquely toward the right distance. $B$, View east along detachment fault (heavy dashes) at north end of Bare Mountain. Lower plate (foreground and right) is of metamorphosed Lower Cambrian and Late Proterozoic rocks. Upper plate is of east-dipping ashflows and tuffs of upper middle Miocene Timber Mountain Tuff. A tectonic lens of unmetamorphosed but severely brecciated Middle or Upper Cambrian carbonate rocks intervenes in the middle distance (below light dashes). Upper plate moved relatively west (left). $C$, View north-northwest along east side of central Bare Mountain, which consists of low-grademetamorphic Lower Cambrian and Late Proterozoic carbonate and clastic rocks. The lateral ridgecrests have been little eroded beneath the detachment fault bounding these lower-plate rocks. Detailed gravity surveys show the bedrock surface to continue with gentle inclination beneath the alluvium. The lack of rangefront scarps in either bedrock step indicate that there has been little if any Quaternary faulting here. (See also part A.)
Proterozoic but may include basal Cambrian in the far southeast. These rocks were metamorphosed to lower greenschist to upper amphibolite facies, probably during Jurassic time (Labotka and Albee, in press). At the southeast end of the exposed complex, where the detachment-fault trace lies along the south side of upper Echo Canyon, Proterozoic lower-plate clastic rocks are metamorphosed at low grade and are now quartzite and glossy slate and phyllite; the sparse clastic rocks in the directly overlying upper-plate Paleozoic section, which consists mostly of carbonates, are nonmetamorphosed sandstone and argillite that lack secondary mica (my observations; also, T.D. Hoisch, oral commun., 1987). Metamorphic grade increases northwestward in the lower plate to upper amphibolite in the far northwest (Labotka, 1980; Labotka and Albee, in press), and the high-grade rocks are intruded by abundant sheets of pegmatite and muscovite granite. Kyanite is present in middle- and high-grade rocks, locally with sillimanite at highest grade; these high-grade rocks formed at a depth of about $20 \mathrm{~km}$ and a temperature near $700^{\circ} \mathrm{C}$ (Giaramita, 1984; Labotka, 1980; Labotka and Albee, in press). At least the high-grade metamorphism must have involved introduction of magmatic heat (Labotka and Albee, in press). Whether the low-grade rocks of the southeast part of the lower plate formed at lesser depth, as I infer, than the high-grade northwestern rocks, or at a comparable depth but much lower temperature, has not been proved.

Foliation and layering are subparallel in the transposed middle- and high-grade rocks of the lower plate, whereas cleavage cuts bedding in the low-grade rocks. Orientation of layering is quite variable, but dominant dips are eastward at gentle to moderate angles (Wright and Troxel, unpublished map).

The central and northwest parts of the lower plate bear a retrograde greenschist-facies carapace, 10 to $150 \mathrm{~m}$ thick, within which foliation and transposed lithologic layers are parallel to the detachment fault that bounds the carapace. Continuity of the carapace on ridge crests shows that the gently domiform topography defined by those crests (fig. $5.4 A, B$ ) is eroded very little beneath the detachment fault. The carapace displays isoclinal ductile and semiductile folding that verges in the same direction, top to the west (fig. 5.5A, $B$ ), as the slip of upper-plate rocks and opposite to fold vergence in nonretrograded amphibolite-facies lowerplate rocks beneath the carapace (fig. 5.6), where I have studied carapace and core in Monarch Canyon and along the western range front. The carapace apparently was developed during the early, deep-seated stage of Tertiary extension. Giaramita (1984) also recognized this west-verging folding and shearing, and its significance, of retrograded high lowerplate rocks at the north end of the lower plate. The carapace in many places has a veneer a few meters thick of mylonitized carbonate rocks, smeared out as a lubricating ductile layer (fig. $5.5 B, C$ ). I saw no carapace at the south end of the lower plate, although as I did not see actual exposures of the fault there, a thin carapace could be present. 


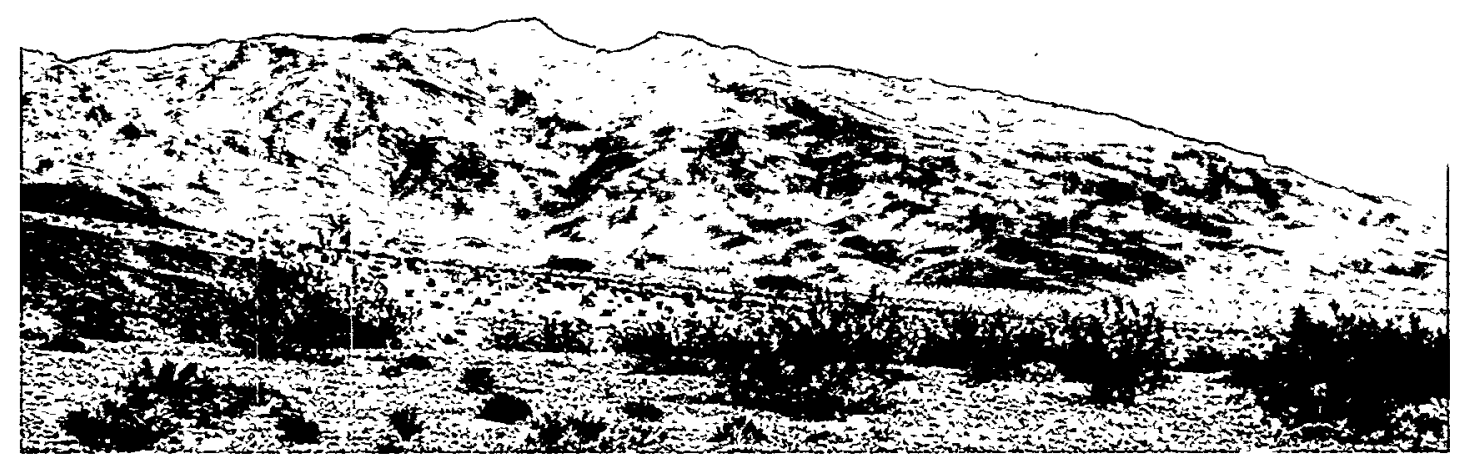

A

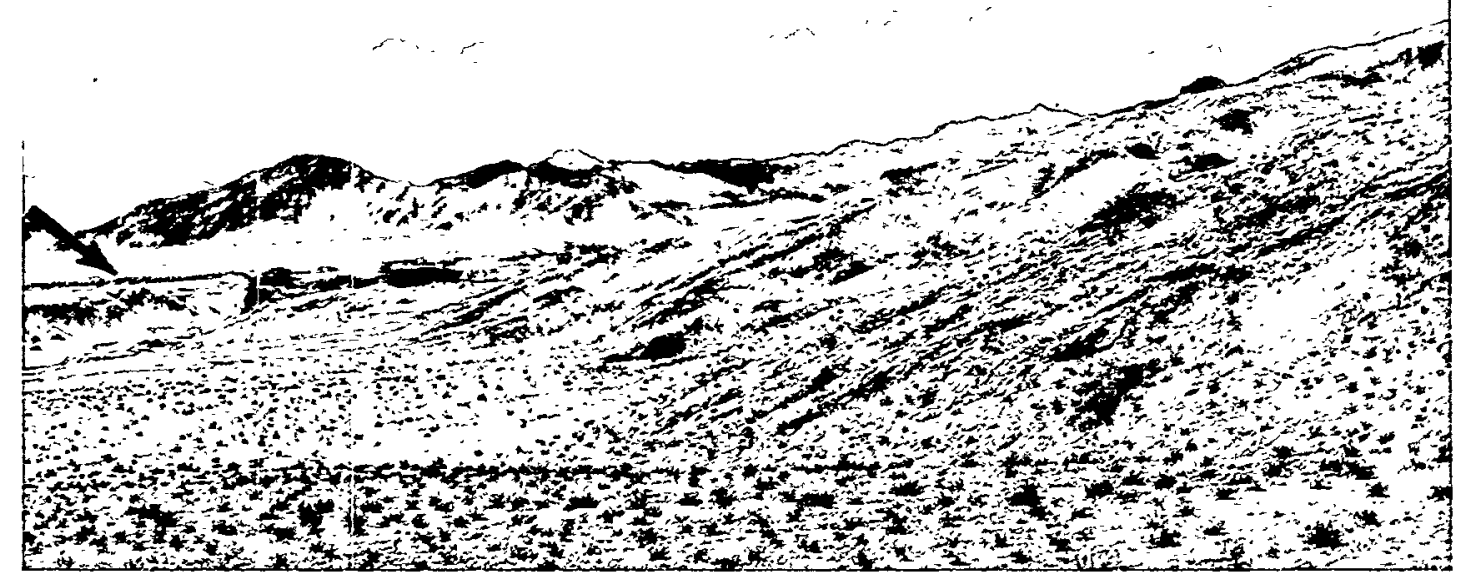

B

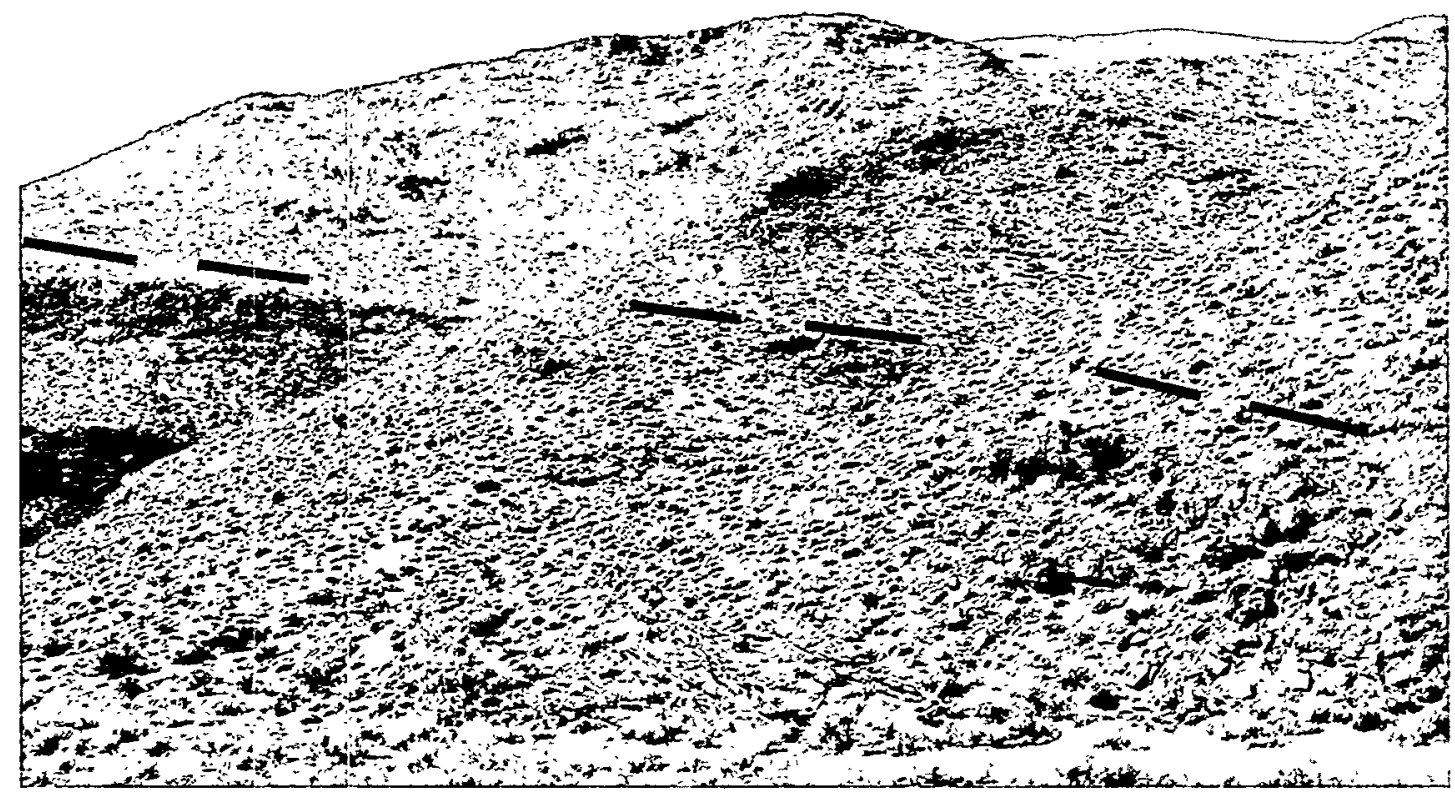

C

58 Geologic and Hydrologic Investigations, Yucca Mountain, Nevada 
Upper-plate rocks, rotated mostly to dip steeply to moderately northeastward in the north and eastward and southeastward elsewhere, and sharply truncated downward against the detachment fault, are nonmetamorphosed Late Proterozoic and Paleozoic sedimentary rocks and upper Oligocene and lower, middle, and lower upper Miocene sedimentary and volcanic rocks (figs. 5.4B, $C, 5.5 C$ ). Upperplate Late Proterozoic and Paleozoic rocks stand mostly as the high, rugged Grapevine and southern Funeral Mountains, whereas Tertiary units, which dominate the upper plate atop the intervening northern and central Funeral Mountains, have mostly been eroded to low ground flanking the dome and are broadly covered by undeformed Quaternary materials. Upper-plate rocks moved relatively westward above all parts of the lower-plate dome, including its east flank and the large klippe on its crest. Upper-plate pre-Tertiary strata are nonmetamorphosed in both the Grapevine and southern Funeral Mountains and show no apparent northwest increase in grade parallel to that of the lower plate. A lens, crescentic in plan, of coherent low-grade metasedimentary rocks intervenes between the main lower plate of high-grade rocks and the upper plate of nonmetamorphosed strata at the north end of the Funeral Mountains. Slide megabreccia layers are intercalated in lower Miocene strata at the west base of the Funeral Mountains (fig. 5.5C), so upper-plate faulting probably was underway by early Miocene time; a late Oligocene age of inception is deduced below from evidence in the Grapevine Mountains.

The complex upper plate in the southeastern Funeral Mountains consists of panels of Paleozoic strata overlain, with broad concordance, by uppermost Oligocene and lower and middle Miocene strata (Cemen and others, 1985), rotated to general eastward and southeastward dips between westand northwest-dipping normal faults (McAllister, 1970, 1971) which mostly have gentle dips and are not known to cut the detachment beneath. This composite of domino panels

Figure 5.4. Domiform detachment fault of the Funeral Mountains. The last slip on this fault occurred during Pliocene time. $A$, View southeastward into the northern Funeral Mountains. The domiform crest is essentially the stripped detachment fault. Sense of slip of upper plate was westward across the dome, from distant left to near right. $B$, View northwestward along the west side of the Funeral Mountains, from Keane Wonder Mill. Mylonitic carapace (layering, right) was developed concordantly below detachment fault by shearing and retrogression of Late Proterozoic middle-grade metasedimentary rocks. Arrow indicates dip of upper-plate middle Tertiary redbeds in low bluff beneath late Quaternary pediment. Upper plate moved relatively leftward. White mass in left middle distance is a Holocene travertine terrace, which here covers the fault trace. Upper-plate Grapevine Mountains in left distance. $C$, View west along domiform detachment fault (lines), northern Funeral Mountains. Unmetamorphosed latest Proterozoic upper-plate clastic strata are truncated downward against lower-plate amphibolite-facies much older Late Proterozoic strata. Head of Monarch Canyon. is in turn broken by a range-front fault, trending southeastward, southwest of which are steeply to moderately dipping early Pliocene strata which overlie the upper Miocene strata of the northern Black Mountains (Cemen and others, 1985; Hunt and Mabey, 1966; McAllister, 1970, 1973). The Pliocene strata are tightly to openly folded about doubly plunging northwest-trending axes (McAllister, 1970, 1973). It appears that extension at the south end of the Funeral Mountains continued through at least early Pliocene time and was followed by modest northeast-southwest shortening, and that the area has been internally stable during at least late Quaternary time. I infer from the complex configuration of the range-front fault that it was rotated to a gentle dip, then broadly folded.

The upper plate in the Grapevine Mountains consists of complexly deformed but nonmetamorphosed latest Proterozoic to Pennsylvanian sedimentary rocks overlain on the northeast by a thick northeast-dipping section of upper Oligocene and Miocene sedimentary and volcanic rocks (Reynolds, 1969, 1976). Sedimentary breccias are intercalated in the Oligocene section, and I assume that these were shed from nearby fault scarps and hence that extension was underway in late Oligocene time. Subhorizontal faults, topographically high in the range, mostly place younger Cambrian rocks on older ones and at least in part display top-to-the-west slip; beneath these faults are large recumbent folds with southwest vergence. Both faults and folds may be products of middle Tertiary extension, the faults having been normal faults that dipped moderately westward before northeastward tilting of the range. Reynolds (1969) mapped many patches of middle Tertiary strata and sedimentary breccia, which, where attitudes are shown, mostly dip moderately downward to subhorizontal contacts, atop high ridges of Cambrian rocks; I infer these contacts to be segments of a rotated range-front fault.

The Grapevine Mountains face Death Valley on the southwest with a high but much-eroded scarp, and the range is cut by deep canyons. This old frontal normal fault trends southeastward into the Funeral Mountains detachment fault but does not cut it-the range-front fault is restricted to the upper plate.

The domiform gravity high of the Funeral Mountains lower plate plunges gently under the Grapevine Mountains upper plate in the northwest and the southern Funeral Mountains upper plate in the southeast (Chapman and others, 1977; Mabey, 1963). Apparently those great upper-plate blocks are perched atop the dome.

\section{Continuity of Faulting between Bare Mountain, Bullfrog Hills, and the Funeral Mountains}

Temperature of metamorphism increased northwestward in the Bare Mountain lower plate, from perhaps $350{ }^{\circ} \mathrm{C}$ to $500{ }^{\circ} \mathrm{C}$, and the Bullfrog Hills lower plate records a yet 
higher temperature and a depth of metamorphism of perhaps $20 \mathrm{~km}$. There appears to be a northwestward increase of depth of exposure in the Bare Mountain and Bullfrog Hills lower plates. The Bare Mountain and Bullfrog Hills detachment faults dip gently toward one another beneath tectonically overlying Miocene volcanic rocks, so likely either both domiform detachment faults expose parts of a single fault surface or else the Bullfrog Hills lower plate represents a deeper crustal lens that emerged from beneath the Bare Mountain one.
This northwestward increase in probable depth of metamorphism parallels that in the continuously exposed lower plate of the Funeral Mountains, where also metapelites increase in grade from slate and phyllite in the southeast to kyanite-staurolite schist in the northwest. Biotite, garnet, and kyanite isograds can be projected from the Funeral Mountains northward and north-northeastward across Amargosa Valley to Bare Mountain and the Bullfrog Hills.

A broad, shallow gravity low lies in Amargosa Valley, between the exposures of the Bare Mountain and Funeral

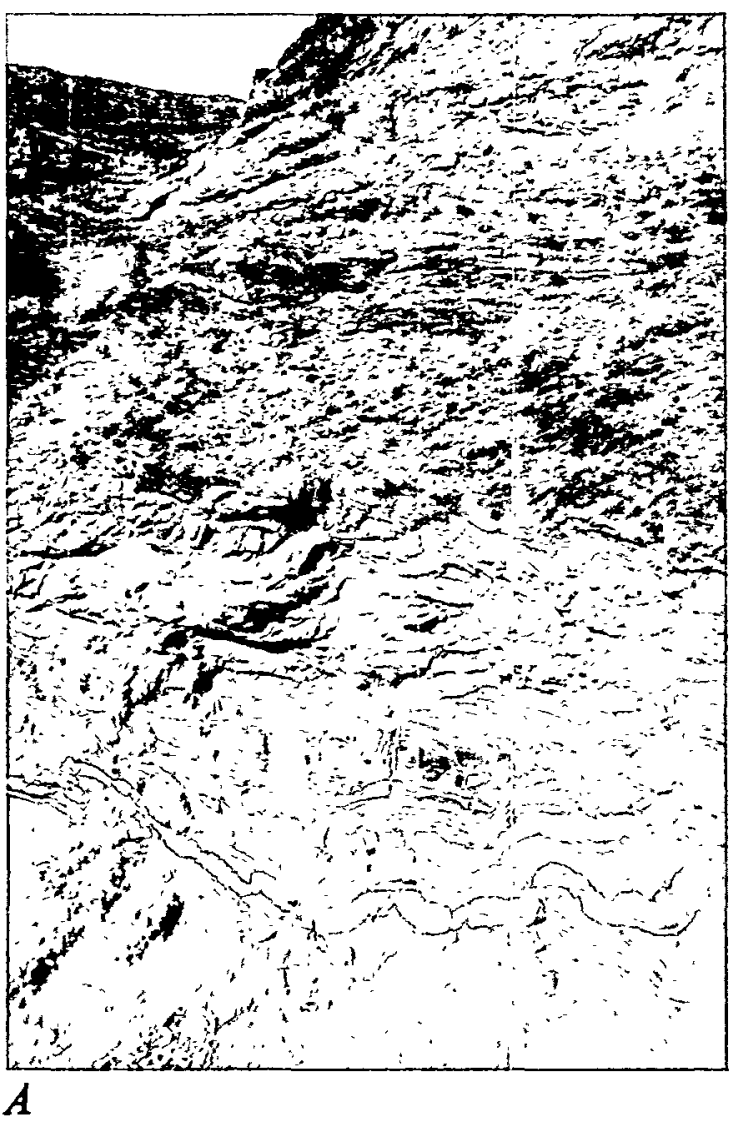

Figure 5.5. Retrograde carapace produced on Funeral Mountains lower plate concordantly beneath detachment fault. Transposition was in same west-directed sense as was slip of overlying upper plate, and represents early deep-seated shearing on the fault system that evolved into the shallow, brittle detachment fault. $A$, Carapace in north wall of Monarch Canyon. Detachment fault projects just above skyline; entire wall, $120 \mathrm{~m}$ high, is in carapace of rocks transposed parallel to fault. Sense of overturning of ductile folds (most conspicuous in sheared white Jurassic? pegmatites) is top-to-the-left (west). Host rocks are Late Proterozoic mica and hornblende schists and, most abundant high on the wall, carbonates. $B$, Mylonitized marble veneer (layered rocks, upper left half of view) atop carapace. Brittle detachment fault is just above the exposure, which is $6 \mathrm{~m}$ high. Dark marble layer near top is deformed in a west-verging isocline; thick marble beneath it is boudinaged; gouge lies beneath boudinaged quartz vein that forms base of layered sequence. Rock at lower right is phyllonitic

$B$

C
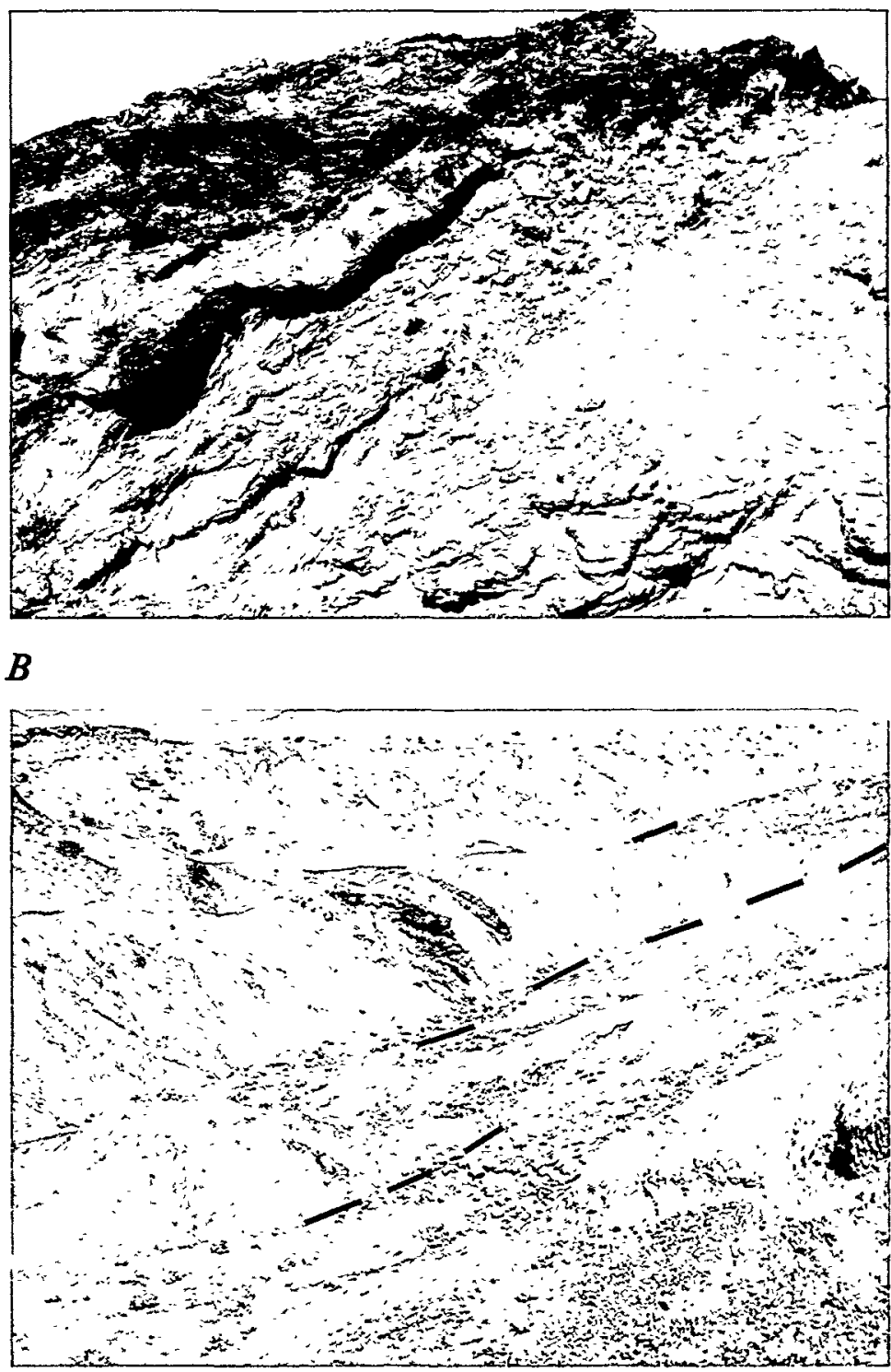

augen schist. View north, $1 \mathrm{~km}$ northwest of Keane Wonder mill. C, Detachment fault, $3 \mathrm{~km}$ northwest of Keane Wonder mill, looking north. Smooth rock surface (right center) sloping gently left is the stripped lower plate of the detachment, which has a veneer $1 \mathrm{~m}$ or so thick of mylonitized marble (light color). Lower Miocene redbeds, tuff, and breccia (left center) dip steeply east to truncation against fault, which is in part marked by dashes. 
Mountains detachment faults (Chapman and others, 1977; Mabey, 1963; Snyder and Carr, 1982). I infer that lowerplate rocks are present at shallow depth throughout this area, that upper-plate rocks consist largely or entirely of lowdensity Cenozoic materials, and that overlying postdetachment Pliocene and Quaternary deposits are thin. Indeed, probable lower-plate rocks make small outcrops near the center of the valley (Swadley and Carr, 1987).

The detachment faults of the Funeral Mountains, Bullfrog Hills, and Bare Mountain may represent upwarps of a continuous fault surface that initially cut west-northwestward down into the crust, from a depth of $10 \mathrm{~km}$ or less in present southeastern exposures to $20 \mathrm{~km}$ or more in northwestern ones, over a present distance of about $30 \mathrm{~km}$. A depth change from $10 \mathrm{~km}$ to $20 \mathrm{~km}$ corresponds to an initial westward dip of about $20^{\circ}$. Gently dipping normal faults have been mapped within the lower plates of Bare Mountain by Cornwall and Kleinhampl (1961), Monsen (1982), and Monsen and M.D. Carr (written commun., 1986, 1987), and of the Funeral Mountains by L.A. Wright and B.W. Troxel (written commun., 1986), indicating that these lower plates were themselves extended; hence, the initial dip of the master fault that is now seen as the detachment was probably steeper than this $20^{\circ}$.

Slip of Late Proterozoic and Paleozoic rocks on this master fault was relatively small in the southeast, for in both Bare Mountain and the Funeral Mountains nonmetamorphosed strata are placed on slightly metamorphosed strata, but large in the northwest, where the nonmetamorphosed rocks of the Grapevine Mountains overlie deep-seated crystalline rocks of the Funeral Mountains and, presumably, the subsurface western projection of the Bullfrog Hills lower plate. The intervening tract of lower-plate rocks was denuded tectonically as the Grapevine block slid across it, and synextensional Tertiary sedimentary and volcanic rocks now form the upper plate in the gap.

Such an explanation accords with the model of B.P. Wernicke, with the addition to his proposed mechanism of extension within the lower plate as well as of the upper plate and with uplift of the lower plate being progressive by sectors. A great normal fault initially dipped westward, more steeply than $20^{\circ}$ by an angle not yet well constrained, to a depth of at least $20 \mathrm{~km}$. The upper-plate rocks initially above the shallow end of this fault were fragmented into great and

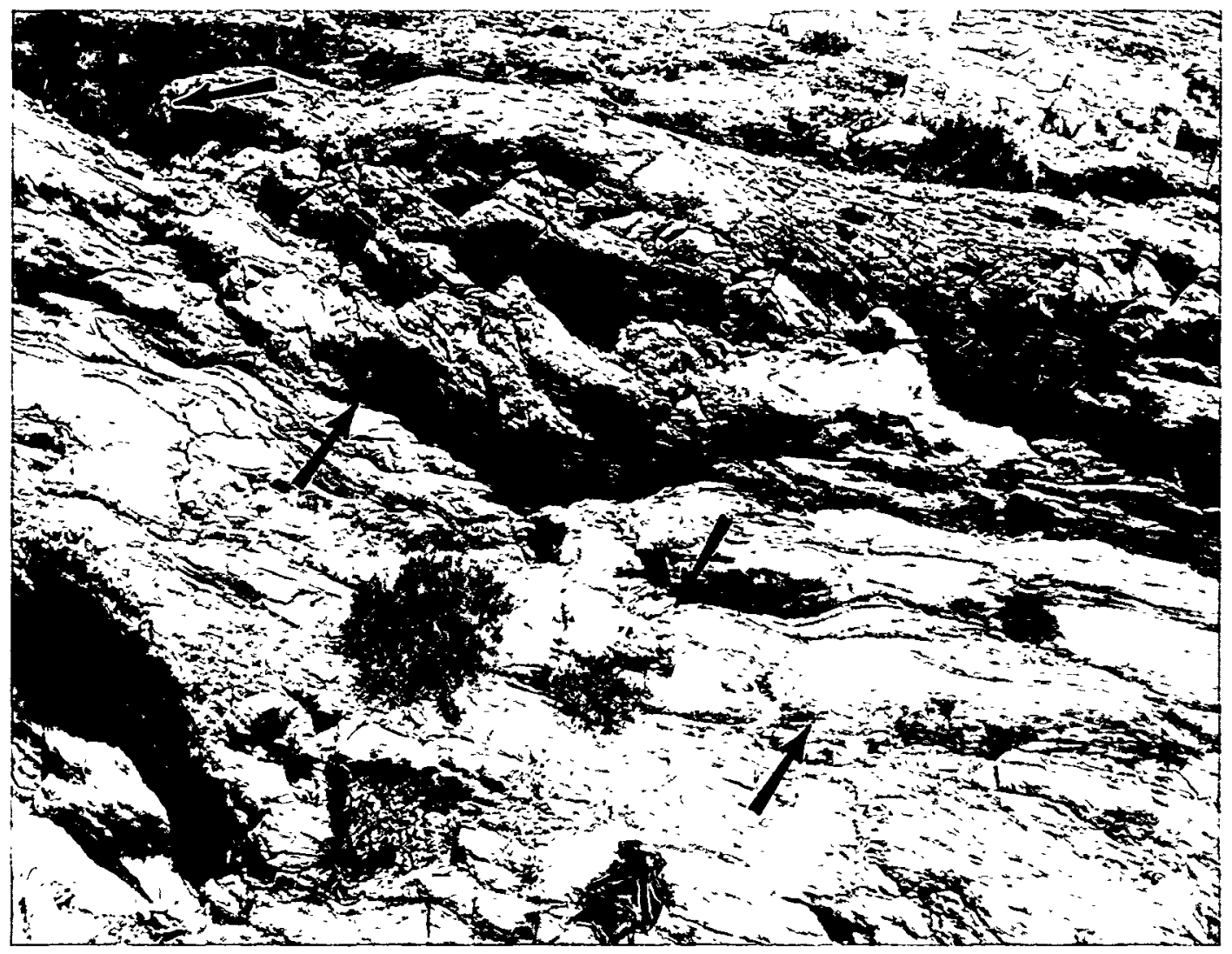

Figure 5.6. Lower-amphibolite facies Late Proterozoic metacarbonate rocks, below carapace in canyon $1 \mathrm{~km}$ east of Keane Wonder mill. S-folds (arrows to hinges) indicate shear of top-up-to-east (left) sensethis Jurassic (?) synmetamorphic shearing had sense opposite to that in Neogene carapace (figs. 5.5A, $B$ ). Exposure $4 \mathrm{~m}$ high. 
small blocks, from the size of ranges such as the Grapevine Mountains downward. The denuded part of the lower plate rose isostatically, eastern upper-plate blocks were stranded atop the flattened sector of the fault while western blocks continued to move, and the age of last slip decreased westward as the hingeline between dipping and flattened fault migrated in that direction.

Biotite and muscovite $\mathrm{K}-\mathrm{Ar}$ ages of pre-Tertiary lowerplate crystalline rocks of the Funeral Mountains, Bullfrog Hills, and northern Bare Mountain scatter from 10 to 50 m.y. old, but most are between 10 and 22 m.y. (M.D. Carr, written commun., 1985; Giaramita, 1984; McKee, 1983; Stern and others, 1966). These ages of cooling presumably record Miocene uplift, by tectonic denudation, from midcrustal depths at which ambient temperatures were above those permitting full retention of argon in the micas.

\section{Imbricate Faulting of Yucca Mountain}

Middle Miocene volcanic rocks, broken and rotated by subparallel west-dipping imbricate normal faults, form a nearly continuous ring from Yucca Mountain westward and southward to the north and south ends of exposure of the Bare Mountain detachment fault. That fault dips gently eastward beneath Crater Flat (fig. 5.3A, C) and hence projects beneath Yucca Mountain, and volcanic rocks correlative with those of Yucca Mountain are rotated down and truncated against the detachment. The extensional deformation of Yucca Mountain likely is a product of slip on the Bare Mountain detachment fault. Yucca Mountain faulting is much more severe in rocks 12.5 to $13.5 \mathrm{~m} . \mathrm{y}$. old than in those less than $11.5 \mathrm{~m} . \mathrm{y}$. old, and was largely completed by 10 m.y. ago (Carr, 1984; Maldonado, 1985; Scott and Bonk, 1984). Dips of Yucca Mountain faults increase, and dips in its strata decrease, away from the exposures of the Bare Mountain detachment fault (Scott, 1986). Late middle Miocene rocks farther east in the Nevada Test Site display much less deformation than do the correlative rocks of Yucca Mountain. There has been little normal faulting since the early late Miocene, and presumably any underlying detachment faults also are inactive or almost so.

Scott and Whitney (1987) deduced from these relations that the west-dipping imbricate faults of Yucca Mountain represent a headwall complex by which slip on the Bare Mountain detachment fault reached the surface, and they argued that the fault does not continue farther east at depth. I agree with their analysis insofar as it applies to the last small bit of detachment faulting, that which postdated $12.5 \mathrm{~m} . \mathrm{y}$. ago. The explanation is not applicable to the earlier very different configuration and vastly greater slip on the fault.

I see Yucca Mountain faulting as having occurred above the $\sim 11-$ m.y.-old hingeline between flattened and dipping master fault. By that time, the tectonically denuded fault surface had risen in the east to an undulating surface on which there was little if any continuing slip, whereas in the west, it still dipped moderately westward so that slip was continuing. This earliest late Miocene hingeline lay far to the west of successively older hingelines and associated headwall complexes, which in turn lay far to the west of the initial positions of their preextension upper- and lower-plate complexes. The upper-plate Grapevine Mountains block had by late Miocene time already gone by-most of the detachment slip predated the Yucca Mountain episode.

\section{BLACK MOUNTAINS}

The central Black Mountains display detachment faults, or undulating exposures of a single fault, the lower plates of which consist entirely of plutonic rocks, and the upper plates of which consist variously of Middle Proterozoic and younger plutonic rocks, Late Proterozoic sedimentary rocks, and Miocene to Quaternary sedimentary and volcanic rocks (fig. 5.2). Early stages of extension, recorded by ductile structures, were presumably of middle Tertiary age; latestage extension, dated by local involvement of upper-plate Neogene strata, was underway by early late Miocene time. Faults in the present medial and eastern Black Mountains are now largely inactive, and may have become so progressively with time from east to west. Along the west side of the range, west-dipping sectors of detachment faults are still active, and perched, active range-front faults in the upper plates end downward against those active detachment faults. These conclusions are based partly on maps and descriptions by Curry (1954), Drewes (1959, 1963), Hunt and Mabey (1966), Noble (1941), Otton (1977), Wright and others (1974), and Wright and Troxel (1984), and partly on my own field reconnaissance.

\section{Amargosa Detachment Fault and Amargosa Chaos}

Noble (1941) recognized, in the low Jubilee Pass area between the central and southern Black Mountains, an undulating fault that separates plutonic rocks beneath from a variety of Proterozoic, Cambrian, and Neogene materials above. The fault surface defines a series of antiforms, dipping and plunging gently, over an area about $15 \mathrm{~km}$ wide across the strike. Noble recognized the consistent westward transport of rocks above the fault relative to those below. He emphasized that a thick crustal section had been cut out across the fault, which he nevertheless assumed to represent Tertiary compressive overthrusting and named the "Amargosa thrust fault." I here refer to the fault as the Amargosa detachment fault. Noble described widespread megabreccia in the upper plate and deduced that it formed by disruption of a thin overriding sheet. He classified the breccia, on the basis of its constituent rock types, into Virgin Springs, Jubilee, and Calico phases of the "Amargosa chaos." 
Much of Noble's area was mapped in detail by Wright and Troxel (1984), and I have toured the area both with Troxel and alone. The interpretations by Wright and Troxel have evolved since their map went to press; my statements in this section represent a mixture of their published interpretations, their subsequent interpretations as I understood them from discussions in 1985 with Troxel and in 1986 with Wright, and my own interpretations. Noble applied his terms very inconsistently, but his " Calico phase of the Amargosa chaos" typically is a coherent upper Miocene formation of volcanic and tuffaceous rocks which include thick marblecake megabreccia apparently formed by intrusion and extrusion of magmas into wet bentonitic mud. Noble's "Jubilee phase" typically is a coherent lower upper Miocene redbed formation that contains intercalated slide megabreccia of mixed plutonic rocks and Late Proterozoic and Tertiary sedimentary rocks. Much of Noble's "Virgin Springs phase" is a discontinuous friction breccia of severely disrupted and attenuated Late Proterozoic sedimentary rocks, as much as $100 \mathrm{~m}$ thick, at the base of the upper plate (fig. 5.7A, B), rubbed off a transiting upper plate of Late Proterozoic sedimentary rocks; Noble lumped the large block of coherent Late Proterozoic strata north of Jubilee Pass with this "chaos." The detachment-fault domes are discontinuously outlined by carapaces of these friction breccias derived from overriding Late Proterozoic rocks, and the carapaces dip both eastward and westward beneath structurally overlying Neogene rocks. This widespread friction carpet of Proterozoic strata between upper-plate Neogene rocks and lowerplate plutonic rocks demonstrates that the parts of the lower plate now overlain tectonically by Tertiary materials have been denuded tectonically by the westward slip of Proterozoic rocks, and hence that the slip recorded by the truncations of Tertiary strata is but a small fraction of the total slip of upper-plate rocks above the faults.

Wright and Troxel (1984) did not make this interpretation and instead inferred the west flanks of the domes to be relatively minor west-dipping normal faults rotated to gentle dips, and the east flanks to be truncated against unexposed west-dipping faults; the map relations to me preclude this interpretation, and I see, as did Noble, an undulating underlying fault. Upper-plate units dip generally eastward to their truncations downward against that fault. Upper-plate rocks are broken by numerous west-dipping normal faults, but as far as I am aware these have not been proven to penetrate the lower plate.

As the various detachment antiforms are separated by upper-plate materials, it is possible that they represent the tops of crustal lenses that are separated by gently dipping shear zones, and that there has been great extension within the lower plate as well as within the upper plate.

The western antiform of the detachment surface in the Jubilee Pass area rises and broadens northwestward to include the plutonic rocks of the high central Black Mountains (fig. 5.2; Desert Hound anticline of Noble, 1941; Wright and Troxel, 1984). On the west, Late Proterozoic sedimen- tary rocks, locally with the Middle Proterozoic plutonic basement rocks on which they were deposited preserved beneath them, form a large east-tilted block that is truncated downward against the detachment fault. Beneath the detachment are plutonic rocks, which include Jurassic granitic and gneissic rocks (I base this correlation on the lithologic similarity of the distinctive but undated megacrystic granodiorite and quartz monzonite here with dated Jurassic granitic rocks of the Mojave Desert and regions to the south), likely also Middle Proterozoic plutonic rocks, and possibly Tertiary granite. A major perched range-front fault bounds the upperplate Proterozoic rocks against east-dipping Neogene strata and megabreccia in the low ground at the west foot of the range. This fault is limited to the upper plate-the fault trends northward into the detachment fault, which there dips gently westward, and ends against it. The west front of the central Black Mountains nearby to the northwest is the detachment surface from which tectonically overlying Neogene strata have been largely stripped. The detachment fault is exposed discontinuously along the foot of the range where upper-plate Pliocene redbeds and basalt are preserved in the low ground. The lower plate here consists of Jurassic granitic rocks; the juxtaposed upper-plate redbeds contain no clasts of this rock type but instead were derived from upper-plate Late Proterozoic rocks similar to those against which the redbeds are faulted by the perched range-front fault to the south, so the redbeds which now form the hanging wall of the detachment fault originated as the hanging wall of an upper-plate normal fault and were rotated downward against the detachment as extension progressed. Along much of this sector, upper-plate rocks are wholly buried beneath upper Quaternary Death. Valley alluvium that laps onto the stripped footwall.

The Amargosa detachment fault along the east side of the Desert Hound antiform was mapped northward to lat $36^{\circ}$ N. by Noble (1941) and Wright and Troxel (1984), and was traced about $2 \mathrm{~km}$ farther north, as the "Amargosa thrust fault," by Drewes (1963). It is not clear from Drewes' reconnaissance map whether the detachment fault continues northward as the structural top of all plutonic rocks or descends into the undivided crystalline rocks; I infer the latter. Drewes schematically mapped breccia, near the contact between plutonic rocks and overlying Tertiary volcanic and sedimentary rocks, of Late Proterozoic or Cambrian formations which he regarded as coherent Paleozoic rocks shuffled with Neogene strata by networks of Neogene thrust and normal faults. I have not seen these complexes but deduce from Drewes' descriptions that the breccia might be a friction carpet atop lower-plate plutonic rocks (in which case they mark a detachment fault structurally high above the Mormon Point turtleback detachment fault at the west foot of the range), or that, more likely, they are slide breccias intercalated stratigraphically in Neogene formations (in which case the subjacent plutonic rocks may be the basement rocks for these formations and be in the upper plate of the Amargosa detachment fault). If the first alternative is correct, then the turtleback faults, discussed next, are the tops 
$\checkmark \forall$ jued u! se 'e!

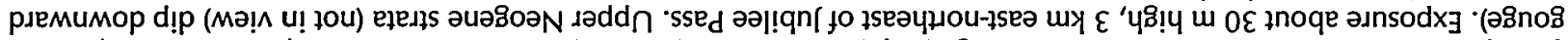

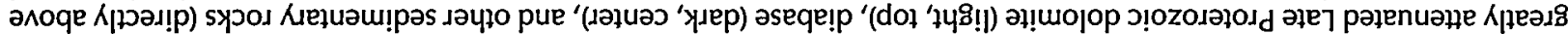

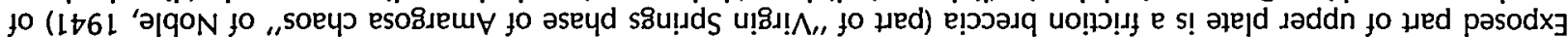

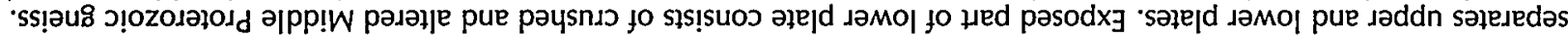

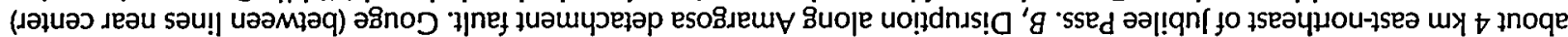

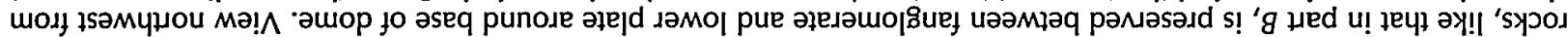

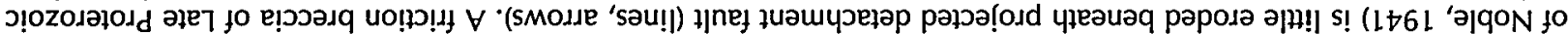
au!|ग!।ue sapoy

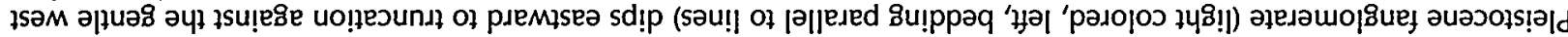

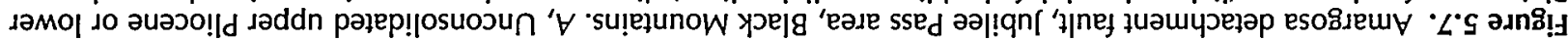
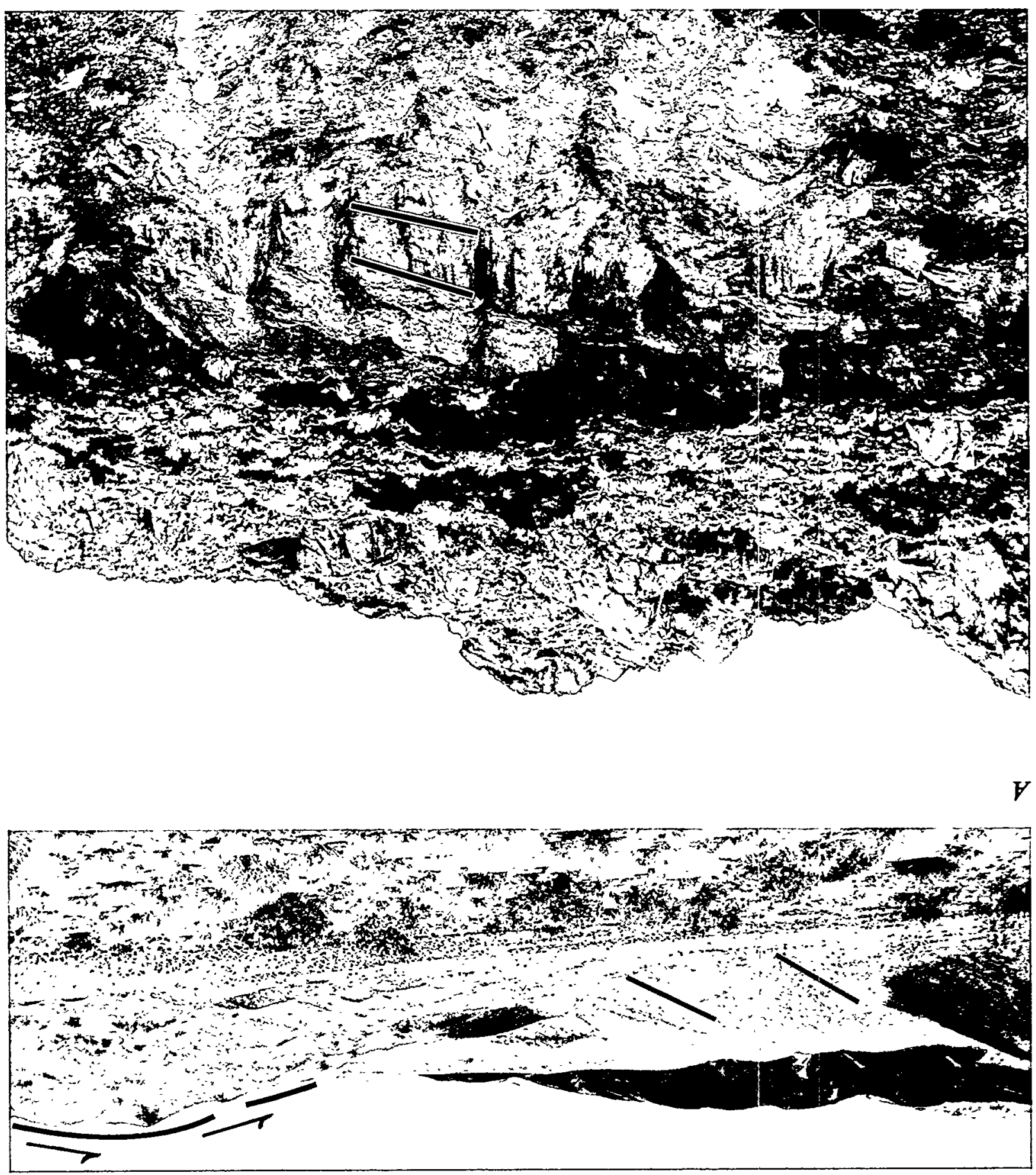
of tectonic lenses deeper than the Amargosa detachment fault. The second alternative appears more likely, however, as the turtleback faults that emerge from beneath these structurally high plutonic rocks bear carapaces of mylonitized Late Proterozoic strata, from which I infer that the turtlebacks represent the same structural level as the Amargosa detachment fault. The denudation of the structurally high plutonic rocks presumably was due to Tertiary extension in any case.

The lower plate of the Amargosa detachment fault is continuously exposed north to the Mormon Point turtleback along the west base of the Black Mountains, and I have arbitrarily connected the east flanks of Mormon Point and Desert Hound anticline structures on figure 5.2.

Around the southern part of the central Black Mountains, middle and upper Miocene volcanic and sedimentary rocks generally dip more steeply than do Pliocene ones (Wright and Troxel, 1984), but all are truncated by the same undulating Amargosa detachment fault. In the western part of this terrane, Pleistocene strata also are rotated, although to gentler dips, in the same general eastward direction (Wright and Troxel, 1984). The abundance of slide megabreccia in late Miocene sections attests to the presence of upper-plate scarps at that time. In the northern Black Mountains, steep-dipping Pliocene strata lie semiconcordantly above upper Miocene ones (Cemen and others, 1985; Hunt and Mabey, 1966). Faulting is still very active at the west foot of the northern Black Mountains.

The southern Black Mountains, south of the area shown in figure 5.2, consist mostly of plutonic rocks, and these, as I read the map of the north edge of them by Wright and Troxel (1984; I have not been in this area), lie entirely beneath the Amargosa detachment fault. The rest of the southern Black Mountains is covered by the 1:250,000 map compiled by Jennings and others (1962) from reconnaissance maps, mostly still unpublished. The compilation map shows the plutonic rocks to be faulted against-overlain structurally by, at least in part-Late Proterozoic, Cambrian(?), and Tertiary strata on the east and south. I infer that the plutonic rocks, about $15 \mathrm{~km}$ by $20 \mathrm{~km}$ in exposed dimensions, lie beneath the Amargosa detachment fault, whether that fault is a continuous single surface or the composite top of separate crustal lenses.

\section{Turtleback Detachment Faults}

Three stripped domiform detachment faults along the west base of the central Black Mountains were aptly termed "turtlebacks" by Curry (1954), who assumed them to be anticlinal folds in a thrust fault. They were studied further by Drewes (1959, 1963), Otton (1977), and Wright and others (1974). Drewes regarded the faults as ancient shear zones along which small surficial blocks are now sliding into Death Valley. Wright and his associates inferred the turtlebacks to be giant mullions on a normal fault which had undergone large late Miocene to Quaternary slip and had evolved from deep and ductile to shallow and brittle.
The turtlebacks are marked on figure 5.2 by the fault closures at Badwater and at Copper Canyon and by the northwest end, at Mormon Point, of the large southern fault dome. The west flank of each of these turtleback detachments is presently active-large active normal faults in the upper plates end downward against them (figs. 5.8, 5.9). The hanging wall of each normal fault becomes the hanging wall also of the detachment fault, down which it is now sliding. Late Quaternary slip of the normal-fault footwall blocks on the detachment faults has not yet been demonstrated.

The turtleback domes plunge $15^{\circ}$ to $25^{\circ}$ northwestward. Flank dips are asymmetric, gentle to the northeast but moderate to the southwest. Concordant mylonitic carapaces fade out downward in the footwall plutonic rocks. Mylonitized Late Proterozoic dolomite and other metasedimentary rocks veneer the Badwater carapace (Curry, 1954) and the northeast flank of the Copper Canyon one (Otton, 1977; figs. $5.9,5.10)$. This veneer represents a smear of rocks not otherwise present locally either above or below those turtlebacks, unless they form part of the Mormon Point lower plate (Otton, 1977). Mullions and mylonitic lineations trend dominantly northwestward along the turtlebacks. Although critical for interpretation of the turtlebacks, it is not clear from published descriptions whether the ductile-slip features of the steep southwest flanks of the turtlebacks correspond to those of the gentle northeast flanks-that is, whether or not the contrasted flanks had similar histories before late Quaternary time. Variable brittle brecciation occurs beneath the faults (fig. 5.10) and postdates the ductile deformation. Gouge zones along the faults vary greatly in thickness, as do friction breccias at the bases of the overriding plates. The slip direction of upper-plate rocks is shown by mylonitic lineations and other structures to have been northwestward during the ductile phase, oblique to the northerly trend of the range, relative to lower-plate rocks.

\section{Upper-Plate Normal Faults}

Normal faults break the rocks above the turtleback detachment faults but end at the detachments.

The Artist's Drive fault of the northern Black Mountains has an imposing west-facing scarp developed from upper Miocene volcanic and tuffaceous rocks (figs. 5.8A). The steep, young part of the scarp is as high as $500 \mathrm{~m}$, and along much of its base is a late Holocene scarp, 5 to $10 \mathrm{~m}$ high, on which northwest-plunging mullions and slickensides indicate oblique slip. Erosion of the 500-m scarp from the fault dip of $50^{\circ}$ or so to the present rugged angle-of-repose slope of $35^{\circ}$ has occurred primarily by landsliding, and late Quaternary slide megabreccias form a hilly apron along the fault.

The abundance of similar megabreccias in Tertiary sections rotated to steep dips and truncated against detachment faults, throughout the Death Valley region as in many other parts of the Basin and Range province, is to me one of many indications that high normal-fault scarps were formed at the 


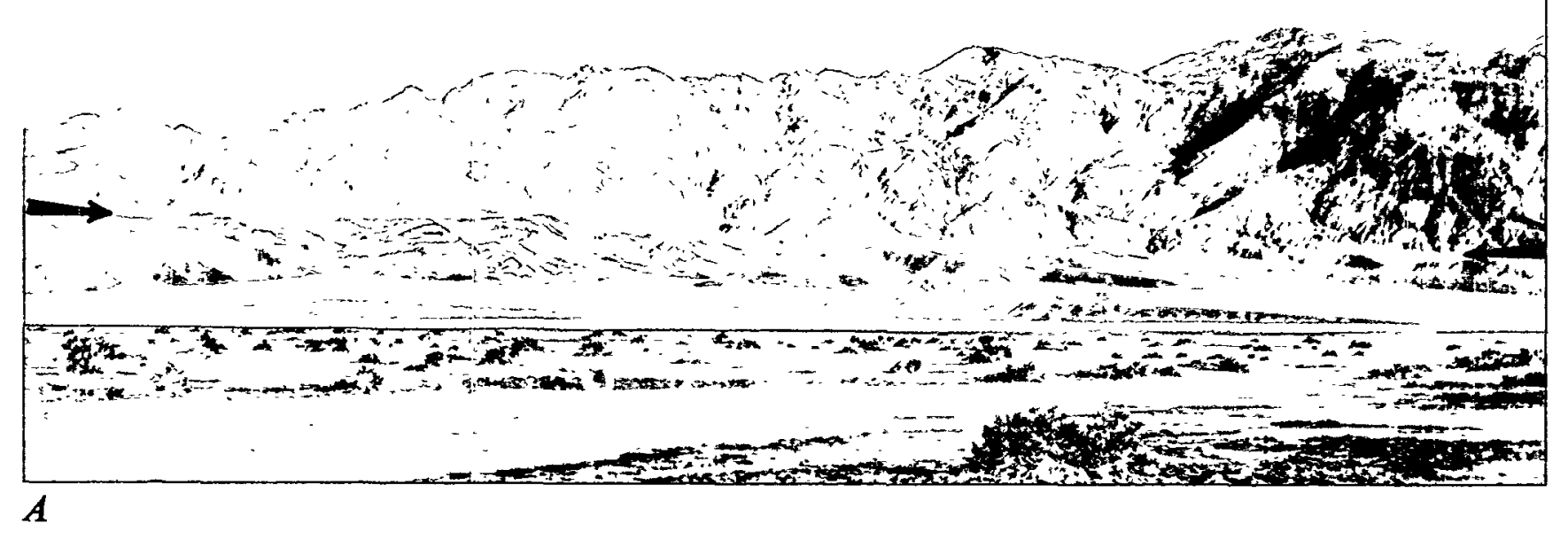

Figure 5.8. Overlapping eastward views showing large rangefront fault of northern Black Mountains truncated downward against Badwater turtleback detachment fault. $A$, Artist's Drive range-front fault (marked by arrows) is a major Quaternary structure with late Holocene slip. High-standing footwall is of upper Neogene volcanic and tuffaceous rocks. Hanging wall (low varicolored hills) includes both downdropped upper Neogene rocks and Quaternary slide megabreccias from the scarp. $B$, Artist's Drive fault (between left and center arrows; see part $A$ ) is truncated against detachment at center arrow. Turtleback surface is stripped dome in center of view. Erosion has caused retreat of the perched scarp (right arrow). As the extensional Artist's Drive fault has Holocene slip, at least the hanging wall of that fault has slipped on the detachment fault in Holocene time. Footwall of Artist's Drive fault is of strongly rotated upper Neogene strata, so it too has had much late Neogene slip on the detachment. surface while major detachment faulting went on at greater depth.

The Artist's Drive fault, the steeply tilted rocks of its footwall, and the slide breccias of its hanging wall are all truncated sharply against the gently dipping Badwater turtleback fault (fig. 5.8B), as Curry (1954) recognized. The extensional Artist's Drive normal fault has had Holocene slip and affects only the upper plate of the detachment system, so the detachment fault beneath the hanging wall of the normal fault must also have had Holocene slip. The footwall Miocene rocks are rotated downward to a sharp truncation against the turtleback, so there must be much young slip beneath the footwall of the normal fault also, although that part of the detachment fault is not known to be presently active. The certainly active part of the gently dipping fault is that which dips westward into the widening Death Valley.

Along strike to the south, another major young normal fault in the upper plate is truncated southward and downward against the Copper Canyon turtleback. Here, the footwall of the normal fault comprises plutonic rocks, and the hanging wall, upper Neogene sedimentary and volcanic rocks rotated to moderate eastward dips; footwall and hanging-wall rocks and the intervening fault end against the smooth detachment fault (fig. 5.9). Drewes $(1959,1963)$ and Otton (1977) both mapped the abrupt truncation of the normal fault against the turtleback and recognized that hanging-wall slip shifted from the normal fault to the turtleback. The turtleback, with its mylonitic carapace and metasedimentary-mylonitic veneer, continues eastward beneath the footwall of the normal fault, and presumably that part of the detachment is now inactive.

Similar relations hold at the north side of the Mormon Point turtleback. A gently dipping, concave-upward fault bounds a block of Pliocene(?) and Quaternary strata, rotated to eastward dips, against the turtleback surface in the south, but against plutonic rocks structurally above the turtleback in the north.

The hanging-wall blocks north of the Mormon Point and Copper Canyon turtlebacks are themselves bounded against the alluvium of Death Valley by active normal faults (fig. 5.9). Latest Pleistocene and Holocene alluvial fan surfaces are broken by small normal faults close to the range front as defined by these upper-plate faults and by the turtlebacks themselves. These steep faults presumably are refracted upward through unconsolidated or poorly consolidated materials from faults that dip more gently at shallow depth. Analogous coseismic structures from the 1959 Hebgen Lake earthquake in Montana were described by Myers and Hamilton (1964).

The southwest side of each of the three turtlebacks is a stripped fault surface that dips markedly more steeply than the northeast side. The alluvial fill of Death Valley is being 


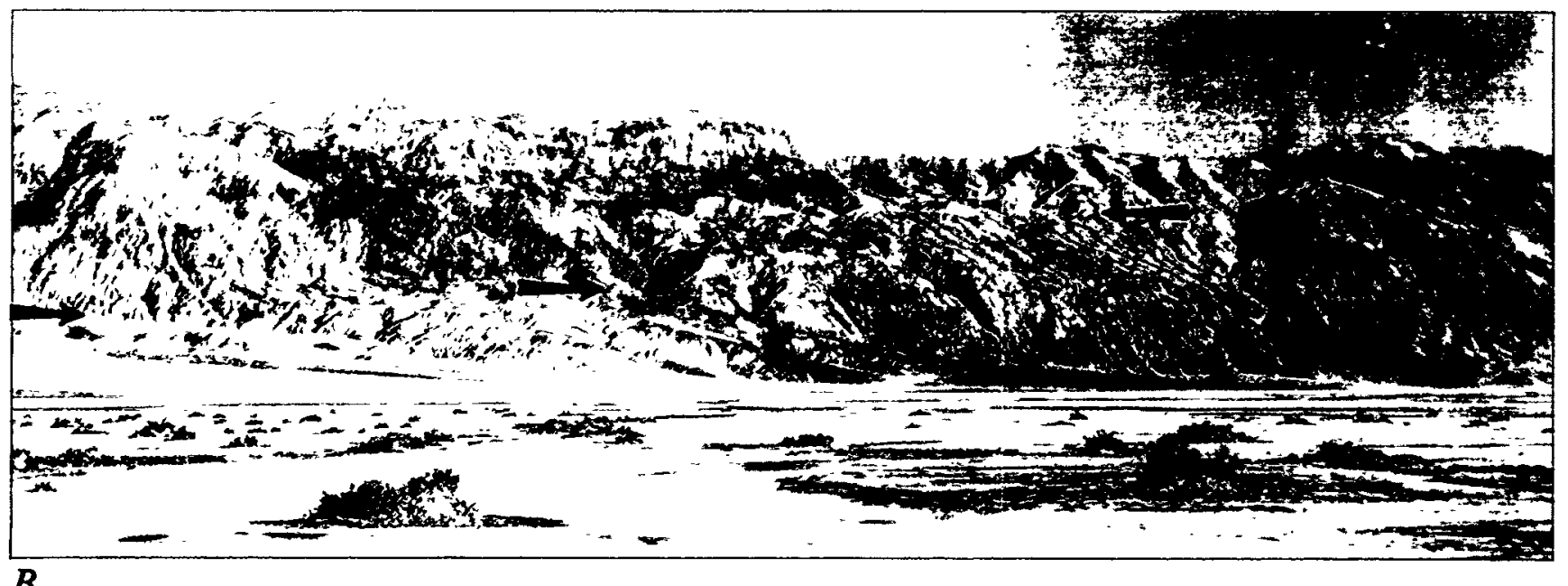

$B$

Figure 5.8. Continued.

actively offset along these steeper faults, for scraps of alluvium cling to the faces high above the present alluvial surfaces. It is not yet clear whether the steep southwest flanks of the turtlebacks share the ductile-slip histories of the gentle northeast flanks or represent younger faults cutting older, gentler structures in some places and merging with them in others.

\section{Continuity of Faulting in Black Mountains}

The detachment faults of the central Black Mountains are exposed as a number of separate plunging domes, no contacts between which are known to be exposed, over a terrane about $15 \mathrm{~km}$ wide and having a proved extent, in a north-northwest direction, of $45 \mathrm{~km}$; the southern Black Mountains terrane, if indeed consisting of subdetachment rocks as discussed above, adds $20 \mathrm{~km}$ more to the length. Are the detachment antiforms structural highs in a single fault surface that is continuous between them, or are at least some of the antiforms the tops of lenses which originated at various structural levels?

Lower-plate rocks consist of granite, migmatite, gneiss, and augen gneiss, so all these rocks may have been in the middle crust when extension began. The meager data available provide an inadequate basis for evaluating the possibility that there is a systematic variation in depth of exposure of these rocks beneath the detachment fault, or faults, in some direction. The presence of carapaces of mylonitic rocks on the turtlebacks in the northwest but of breccias on the domes in the Jubilee Pass area perhaps indicates that early slip on the former was at a greater depth than that on the latter, but the possible contrast has been too little studied for confident analysis.
The upper plate of the central Black Mountains, above the turtleback detachment faults, consists of plutonic rocks overlain directly by upper Miocene strata. Presumably the plutonic rocks were exposed at the surface by tectonic denudation after the Panamint Mountains block had passed across this region, and the lower plate of that structure was broken in turn by structurally lower faults.

\section{Relation between Detachment Faults of the Black and Funeral Mountains}

The thick section of upper Miocene and Pliocene sedimentary and volcanic rocks that on the west side of the Black Mountains is truncated downward against the turtleback detachment faults dips steeply to moderately northeastward off the northeast side of the range to a truncation against the inactive range-front fault of the southeastern Funeral Mountains. This frontal fault likely is limited to the upper plate of a detachment system. The axis of the gravity low that presumably marks the deepest part of the base of the Neogene strata lies only a few kilometers from the trace of the range-front fault (Chapman and others, 1977; Mabey, 1963). The shallowness of this gravity low precludes the presence of more than 1 or $2 \mathrm{~km}$ of the low-density strata, so the Neogene section projects downdip to a shallow truncation against gently dipping faults atop dense rocks. A northwest-trending gravity high in an area of upper Neogene strata of the northeastern Black Mountains, midway between the Badwater turtleback and the gravity low in front of the Funeral Mountains, may mark a hidden turtleback in the underlying detachment system. 
Possibly Black Mountains and Funeral Mountains detachment faults may be continuous beneath the upper-plate strata that intervene at the surface, and the gravity low in this case should define the deepest part of the flexed fault. Alternatively, the frontal fault of the Funeral Mountains may break the Black Mountains detachment fault beneath the basin axis. The structure in any case represents but a minor late stage in the extension in this area, for, as discussed subsequently, the Panamint Mountains upper-plate block likely was torn from the Funeral Mountains and transported across the Black Mountains detachment system and rifted across Death Valley.

\section{PANAMINT MOUNTAINS}

The Panamint Mountains mostly comprise a great easttilted block that is allochthonous above a major detachment fault, exposed around Hanaupah and Death Valley Canyons at the east foot of the range, which I here term the Hanaupah detachment fault. The upper-plate block is complicated by many normal faults rotated and deformed with the block. Most of these faults are relatively minor, with slips on the order of a kilometer or so each, but aggregate slip on the large faults of the structurally high Tucki detachment-fault system is probably several tens of kilometers. The imbricate Hanaupah and Tucki detachments both cut out thick crustal sections.

\section{Hanaupah Detachment Fault}

The Hanaupah detachment fault is exposed at the east base of the range and there dips about $15^{\circ}$ westward. It was mapped and described by Hunt and Mabey (1966), who recognized it as an extensional structure although they referred to it as the "Amargosa thrust fault." The lower plate consists of augen gneiss in which mylonitization increases upward toward the detachment fault. The protolith is undated but presumably is either Middle Proterozoic or Jurassic. The $\mathrm{K}$-Ar ages of biotite in two samples of gneiss are 11 and 14 m.y. (Stern and others, 1966). The gneiss is intruded by very abundant silicic and intermediate Tertiary dikes which, although undeformed, display much static argillic alteration. Dikes dip about $70^{\circ}$ westward where I examined them north of Hanaupah Canyon, and they appear to have a similar steep westward dip in a photograph in Hunt and Mabey (1966, fig. 97), although they (p. 137) referred to the dikes in one locality as "nearly vertical."

Upper-plate rocks, as truncated against lower-plate mylonitic gneiss along the exposed part of the Hanaupah detachment fault, are east-dipping upper Miocene volcanic rocks intercalated with slide breccias, and, unconformably beneath them and dipping more steeply eastward, nonmetamorphosed Ordovician and older strata (Cemen and others, 1985; Hunt and Mabey, 1966). These Phanerozoic

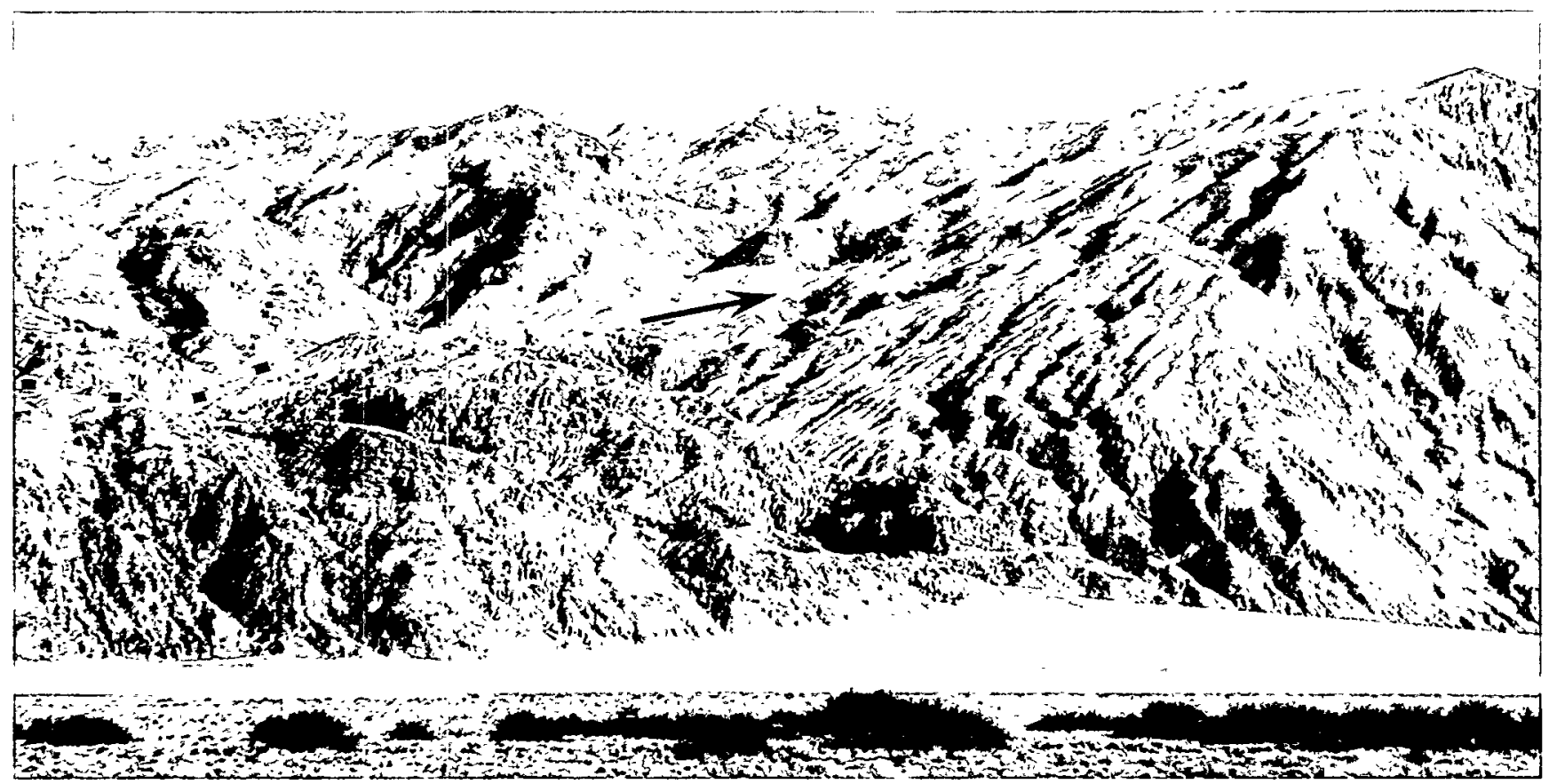

Figure 5.9. View east at upper-plate normal fault truncated downward against Copper Canyon turtleback detachment fau!t (smooth face right of arrow; has mylonitic veneer of light metacarbonates). Active normal fault (along dots on left, arrow on right) has footwall (above) of plutonic rocks and hanging wall (below) of upper Neogene volcanic rocks. Fault is truncated against detachment fault at point of arrow. Neogene rocks are sliding down detachment fault and are rotated back into it. Detachment swings into steeper range-front fault on right; upperplate Neogene rocks are broken by range-front fault on left.

68 Geologic and Hydrologic Investigations, Yucca Mountain, Nevada 


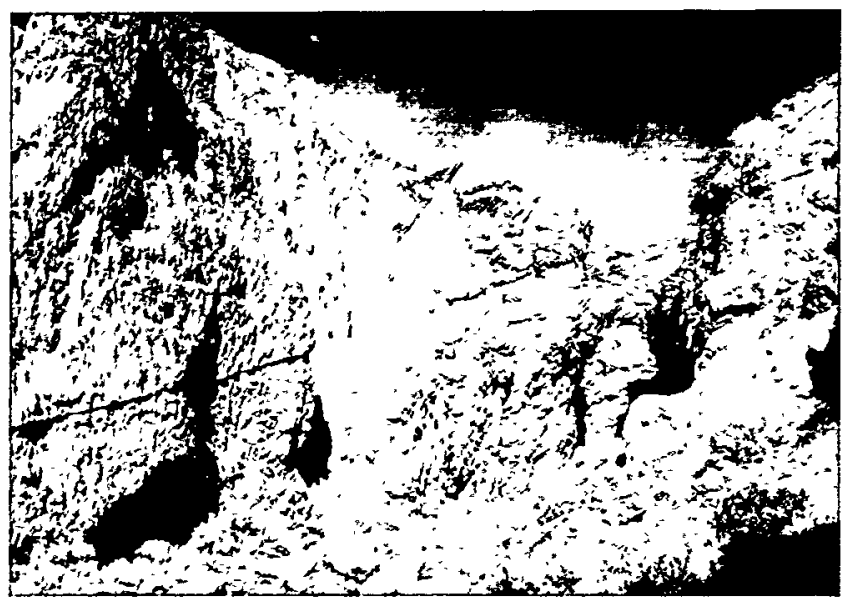

Figure 5.10. Mormon Point turtleback detachment fault as the range-front fault of the central Black Mountains. Fault dips $20^{\circ}$ west (obliquely toward left front). Upper plate is of Quaternary fanglomerate, which dips gently back to truncation against fault. Lower-plate friction breccia of Late Proterozoic metadolomite is broken into phacoids whose long axes lie in strike direction.

rocks are the structural top of the main, east-tilted allochthonous Panamint block. Upper- and lower-plate rocks are brittly intersheared along the fault, and a thick breccia of upper-plate rocks lies atop part of it (Hunt and Mabey, 1966). The detachment fault is now inactive.

I infer that lower-plate mylonitization took place during early, ductile deep-seated slip on the detachment fault, in or before middle Miocene time, and that the lower plate was still at a temperature of perhaps $200{ }^{\circ} \mathrm{C}$ when the postmylonitization dikes were intruded into it after middle Miocene time. Late, brittle slip was at least largely younger than the dikes. Eastward tilting of the lower plate by about $20^{\circ}$ after emplacement of the dikes likely is indicated by the present attitude of the dikes, so the lower plate is itself allochthonous above some deeper structure, and the detachment fault likely dipped about $35^{\circ}$ westward when the dikes were intruded into the lower plate.

\section{Tucki Detachment-Fault System}

Detachment faults form a domiform complex, here referred to as the Tucki detachment-fault system, in the northern Panamint Mountains, recognized as of extensional origin by Hunt and Mabey (1966). These structures lie within the upper plate of the Hanaupah detachment fault. The lowest fault of the Tucki system defines a dome, outlined by a mylonitic carapace beneath the late brittle fault, which has flank dips of $15^{\circ}$ to $30^{\circ}$, a broad crest, and a plunge of about $20^{\circ}$ northward (figs. 5.11, 5.12; Hunt and Mabey, 1966; Wernicke and others, 1986; my observations). Although domiform, the fault cuts structurally downward westward in the lower plate, which consists of Late Proterozoic strata, metamorphosed to greenschist and amphibolite facies, and Mesozoic muscovite granite. The mylonitic carapace comprises rocks retrograded to lower greenschist facies and severely transposed parallel to the domiform fault that caps the carapace, is a few tens of meters to perhaps $100 \mathrm{~m}$ thick, and is developed discordantly across the higher grade rocks beneath (fig. 5:12B-D). Above the carapace and detachment fault is a zone of gouge and incoherent breccia 3 to $50 \mathrm{~m}$ thick (fig. 5.12B).

Upper-plate units mostly dip steeply to moderately eastward and are truncated against the detachment fault. Upper-plate rocks low on the west side of the dome are Pliocene fluvial strata, slide megabreccia, and basalt (Hall, 1971; J.E. Conrad and E.H. McKee, written communs., 1985; Hunt and Mabey, 1966; Larsen, 1979; Wernicke and others, 1986; my observations), faulted directly against the lower plate (fig. 5.12E).

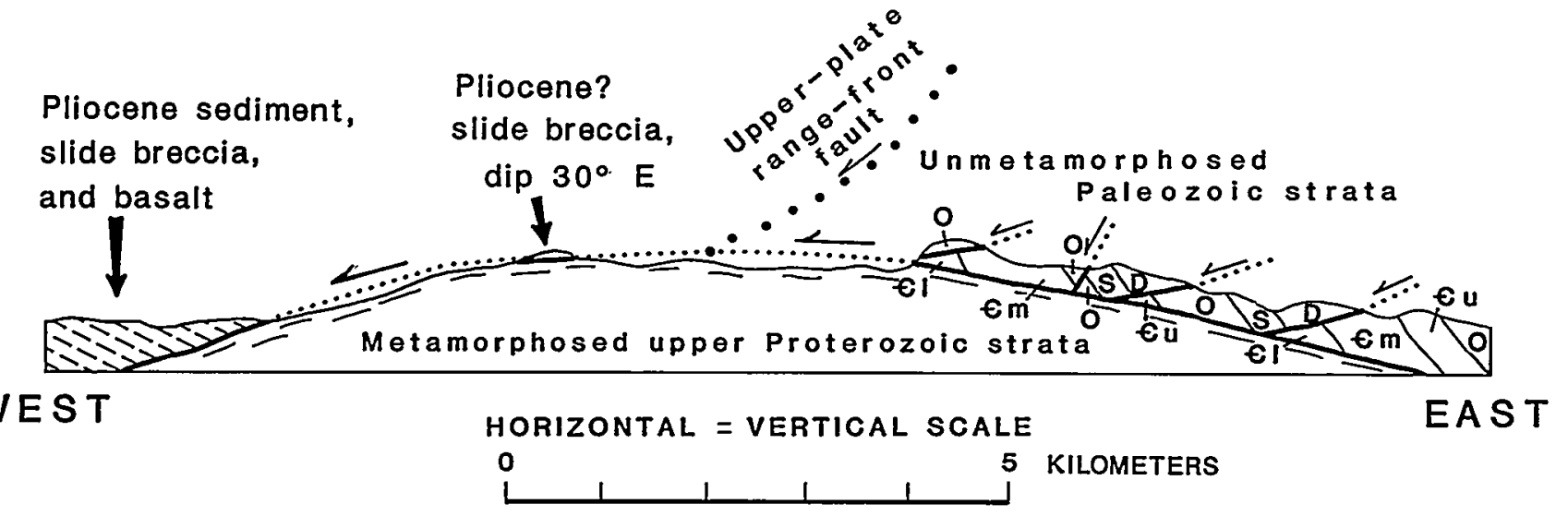

Figure 5.11. Section across Tucki Mountain domiform detachment fault, near north end of Panamint Mountains. Sense of slip of upper plate is westward on both flanks of the dome. Paleozoic strata: $-\mathrm{Cl},-\mathrm{Em}$, and $-\mathrm{Cu}$, Lower, Middle, and Upper Cambrian; O, Ordovician; S, Silurian; D, Devonian. Adapted from Hunt and Mabey (1966, fig. 86). 


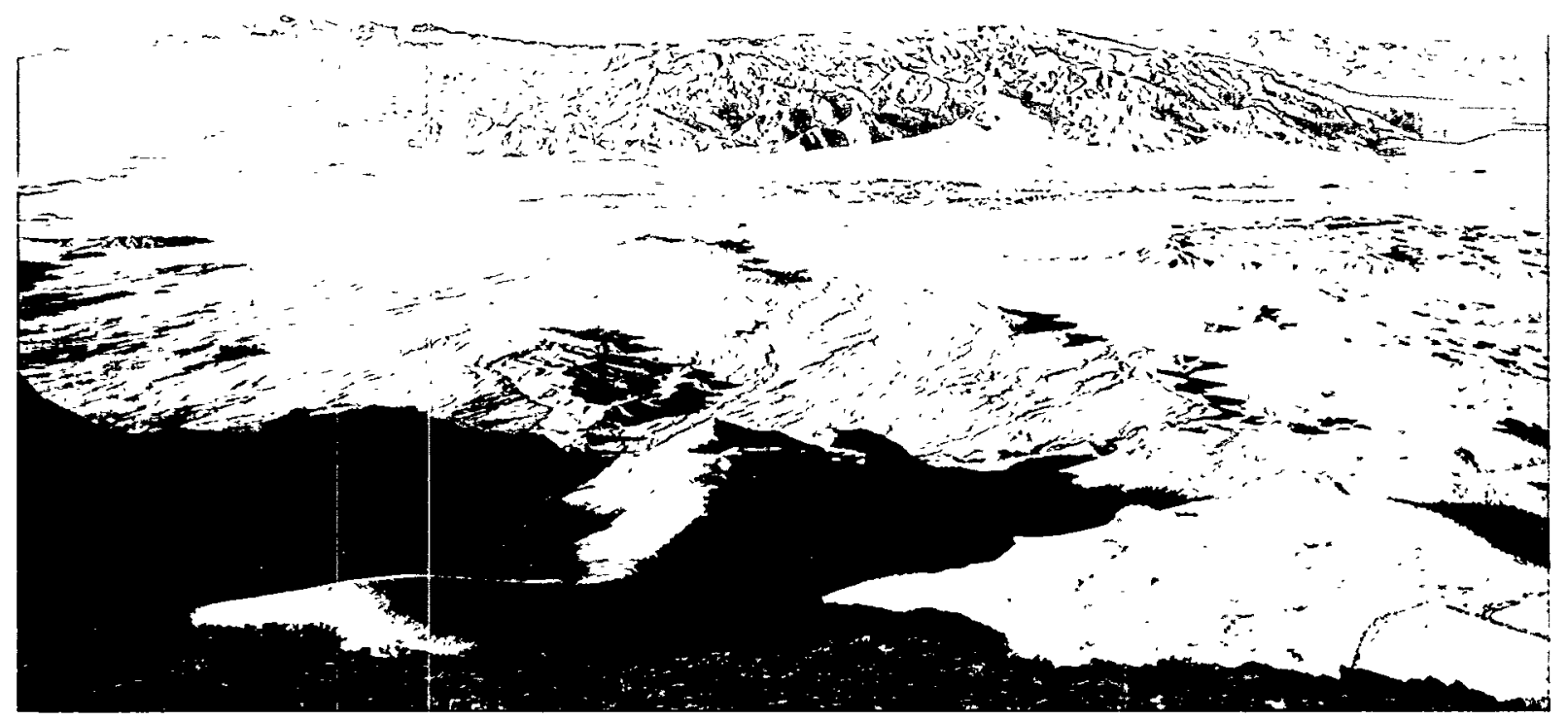

$A$

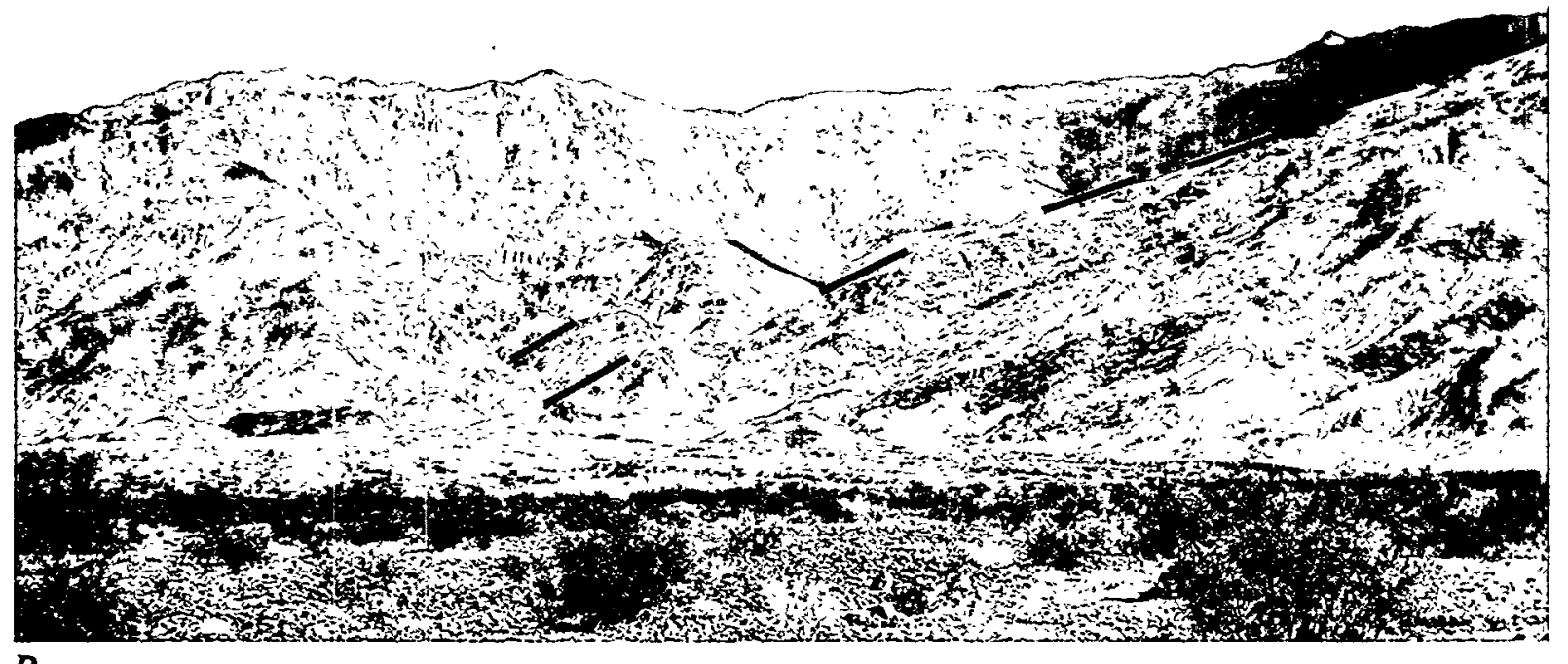
$B$

Figure 5.12. Domiform Tucki detachment fault at the north end of the Panamint Mountains. A, View southsouthwestward across Death Valley to Panamint Mountains, from crest of northern Funeral Mountains. Valley floor lies below sea level; Telescope Peak (left skyline) rises to almost $3400 \mathrm{~m}$. Entire Panamint block is allochthonous above the Hanaupah detachment fault, exposed along base of range on left. Broad dome of Tucki Mountain (right) is little eroded lower plate of Tucki detachment fault. Crests of foreground ridges are little eroded beneath Funeral Mountains detachment fauit; low hills projecting through fans beyond are of upper-plate middle Tertiary strata that mostly dip east toward detachment. $B$, View south to Mosaic Canyon and east flank of dome. Smooth slope on right, marked by lines, is stripped detachment surface; mylonitic carapace $50 \mathrm{~m}$ or so thick produces layers on top of lower plate of Late Proterozoic metasedimentary rocks. Upper plate (upper left) is of unmetamorphosed Paleozoic carbonate rocks. Sense of slip of upper plate was westward (upward and right). A zone of gouge and breccia (between lines left of mouth of canyon) separates plates. Top of lower plate swings along rangefront on right but upper plate has slid, or been eroded, away. C, Boudinaged and mylonitized Late Proterozoic metadolomite in retrograded carapace beneath Tucki detachment fault. Face is about $10 \mathrm{~m}$ high; top is about $20 \mathrm{~m}$ below the detachment fault; view eastward. Mosaic Canyon, near mouth. $D$, Metadolomite carapace at top of lower plate. Left skyline is the stripped detachment fault, from which has been eroded south-dipping Pliocene or Pleistocene fanglomerate. Microbrecciated metadolomite (above lines) has been transposed discordantly across variably disrupted metaclastic rocks; both are Late Proterozoic. View eastward, about $3 \mathrm{~km}$ west of Mosaic Canyon. E, West flank of dome. Smooth bedrock slope is stripped detachment, dipping gently west, on Late Proterozoic metasedimentary rocks and Mesozoic muscovite granite. Unconsolidated upper Pliocene or lower Pleistocene alluvium dips (lines) east to truncation against detachment. Emigrant Wash. 
On the crest and east flank of the dome, two large normal faults (Trellis Canyon and Tucki Wash faults of Wernicke and others, 1986; fig. 5.2) and several lesser ones, each with top-to-the-west slip but now rotated to gentle dips to either west or east, form an imbricate array and merge with the basal fault (Hunt and Mabey, 1966; Wernicke and others, 1986). In the west part of this complex, where the

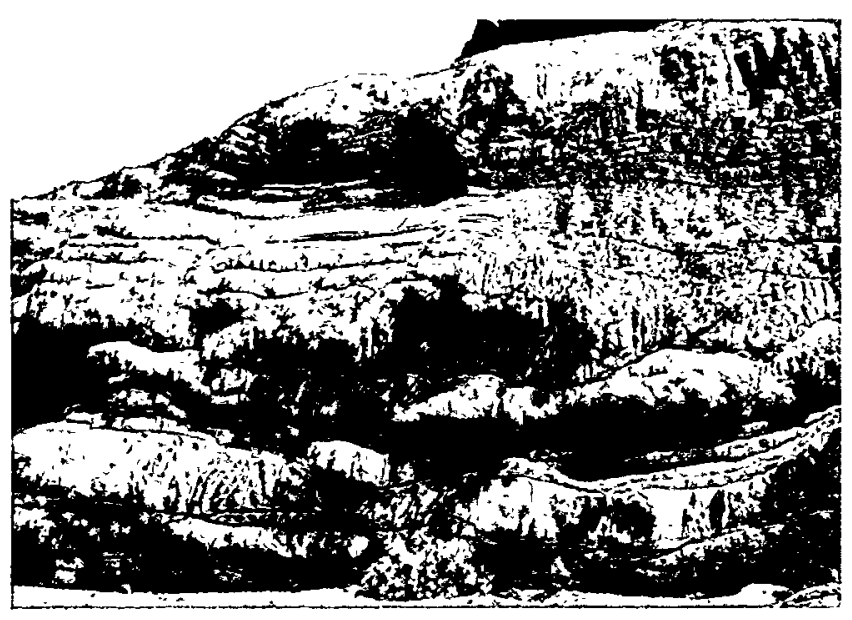

C
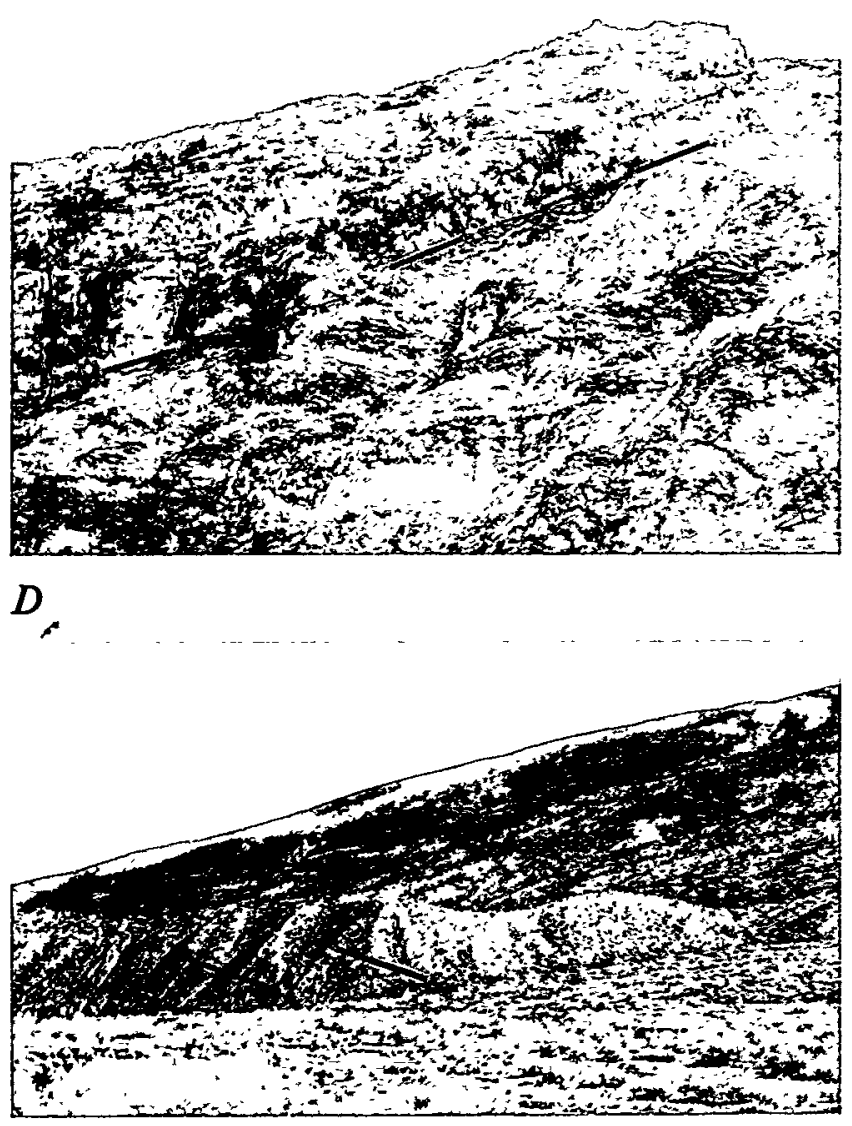

E

Figure 5.12. Continued. aggregate slip on all of the faults is represented by the basal fault at Mosaic Canyon, nonmetamorphosed Cambrian strata are placed on metamorphosed Late Proterozoic lower-plate rocks (fig. $5.12 B$ ), and at least $10 \mathrm{~km}$ of crustal section is missing; but in the east, beyond the inflection away from the fault of the structurally higher imbricate faults, the basal fault (Harrisburg fault of Wernicke and others) merely places less metamorphosed Late Proterozoic strata on slightly older and more metamorphosed strata. Lower Cambrian formations lie $15 \mathrm{~km}$ farther west at the top of the imbricate stack than at the base. This distance is the minimum aggregate offset across the imbricate faults. The stratigraphically highest rocks in the east-dipping panels above the imbricate faults are present at the east foot of the northern Panamints, where strata of probable middle Miocene age overlie Devonian strata, both dipping steeply eastward, and are in hidden contact with steeply dipping unconsolidated boulder deposits presumed to be of late Pliocene or early Quaternary age (Wernicke and others, 1986; B.P. Wernicke, oral commun., 1987).

A west-dipping range-front fault, which ended downward against the detachment, must have been eroded from above the Tucki dome (fig. 5.11). This fault separated preTertiary upper-plate rocks, on the east, from Pliocene ones, on the west. The Cottonwood Mountains consist of Paleozoic rocks that presumably overrode the dome and were faulted away from east-flank rocks, which thus had a lesser slip relative to the dome than did the Cottonwood rocks, but a greater slip than did the Pliocene materials. An upper-plate fault at the north edge of the dome breaks relatively old Quaternary fanglomerate, and upper-plate materials may presently be sliding down the detachment fault into the deep Mesquite Flat basin to the north.

The Tucki detachment-fault system thus records a long period of slip that began when the lower plate was deep enough so that slip was ductile and synmetamorphic and that continued at least through Pliocene time as the lower plate was denuded tectonically and rose toward the surface. The Neogene upper-plate rocks did not exist when slip began, and the histories of various parts of the fault system were very different. The total amount of slip of pre-Tertiary upperplate rocks across the lower plate increased westward, although the present tectonic cover low on the west flank is of Pliocene strata that may have slid only a few kilometers.

\section{Central Panamint Mountains}

The central and southern Panamint Mountains, as mapped and described by Albee and others (1981), Hunt and Mabey (1966), Labotka and Albee (in press), and Labotka and others (1980), consist of a great block, tilted to a general eastward dip of about $20^{\circ}$ and eroded obliquely through a crustal section 10 or $12 \mathrm{~km}$ thick. This block is allochthonous above the Hanaupah detachment fault, which shares much 
of the eastward rotation of the block, but mostly lies structurally beneath the faults of the Tucki detachment system. The down-section progression of this huge block begins in the east with upper Miocene (Cemen and others, 1985) volcanic rocks and slide breccia, which dip less steeply eastward than do the underlying nonmetamorphosed Ordovician and Cambrian strata and hence may have been deposited after extension was underway. The crustal section continues westward and downward through increasingly metamorphosed Proterozoic rocks, bearing andalusite or tremolite at lower grades, and sillimanite or diopside in the deepest and highest temperature rocks. Shallow, crosscutting Miocene(?) granite is intruded above the middle of the crustal section, and semiconcordant Jurassic(?) muscovite granite occurs low in it; the amphibolite-facies metamorphism resulted from heat added by Jurassic granite and fluids (Labotka and Albee, in press). Normal faults, rotated with the block so that they now dip gently, break the east-dipping crustal section with small top-to-the-west slips that do not grossly disrupt the succession, and these faults presumably merge with the underlying detachment fault.

Offset on the relatively minor fault that bounds the east flank of the Tucki lower-plate dome decreases southward, as mapped by Wernicke and others (1986), and the fault apparently dies out within the little-broken main Panamint block near Wildrose Canyon and the north edge of the Telescope Peak quadrangle as mapped by Albee and others (1981).

The gently dipping west-flank fault of the Tucki complex, by contrast, continues southward as the boundary between the main Panamint block and east-tilted Pliocene or lower Pleistocene strata. As shown by Wernicke and others (1986, fig. 2) and as followed also by me, the trace of the fault swings around the Skidoo pluton of Hunt and Mabey (1966), trends southward beneath the fill of Harrisburg Flats, emerges at Emigrant Pass, and trends southwestward. I found the fault to continue southward across Wildrose Canyon near its mouth (fig. 5.13A); I infer that it trends thence generally south-southeastward in the northwest corner of the Telescope Peak quadrangle to become the fault mapped by Albee and others (1981), between Jail and Happy Canyons, that dips gently westward between a footwall of varied crystalline rocks and a hanging wall of spectacular eastdipping monolithologic slide breccia (fig. 5.13B, C). Labotka and others (1980) calculated that the source of the breccias lay about $3 \mathrm{~km}$ updip in the footwall, so the postPliocene slip on the fault has been small. The fault must have been a range-front structure when the breccia was deposited. Weakly cemented Quaternary gravels that lie unconformably on tilted Pliocene strata, near the fault trace around the mouth of Wildrose Canyon, are broken by normal faults with individual offsets of as much as several tens of meters, so slip likely is continuing on the gently dipping fault beneath, but probably not on the fault at its surface trace.

Hanging-wall breccias dip $15^{\circ}$ to $20^{\circ}$ eastward into the fault, which dips $20^{\circ}$ to $30^{\circ}$ westward (fig. $5.13 B, C$ ), but likely were deposited with dips of about $10^{\circ}$ away from the fault. Hanging wall, fault, and footwall have apparently been rotated together about $30^{\circ}$ eastward. The main tilting of the Panamint upper-plate block thus has taken place within late Pliocene and Quaternary time, presumably above a deep detachment fault. As the Hanaupah detachment fault and its lower plate, at the exposed east base of the Panamint block, have also been rotated about $20^{\circ}$ eastward, some still-deeper detachment fault must be involved.

The unconsolidated slide breccias of the hanging wall of the main fault are being rapidly eroded away, leaving the stripped footwall exposed as a high scarp (fig. 5.13C). Many steep range fronts of large, tilted fault blocks in the Great Basin likely also have been stripped from rotated faults within the upper plates of detachment systems, rather than having been, as usually interpreted, eroded back from steep faults that directly bound adjacent alluviated basins.

The footwall where of granite has a thick mylonitic carapace (fig. $5.13 B$ ), and where of metasedimentary rocks has a veneer of ductile-deformation rocks (fig. 5.13C). Late slip on the fault, including the few kilometers of offset of Pliocene strata, took place near the surface; but I infer from the ductile structures that much greater slip took place earlier while the footwall was at middle-crust depths. The fault evolved with time from a deep detachment to a shallow rangefront fault.

Klippen of east-dipping rocks, requiring large top-tothe-west offset above faults that now dip only very gently westward, cap ridges in the medial part of the main Panamint block north of upper Wildrose Canyon (Wernicke and others, 1986). Presumably these faults are analogous to those atop the Tucki dome farther north and record pre-range-front faulting on the detachment.

\section{OPENING OF DEATH VALLEY}

Death Valley is now being widened obliquely as the ranges to the west move relatively northwestward away from those to the east. The general eastern boundary of rapid extensional deformation in these latitudes lies within or at the east side of Death Valley. In the central sector, between the Panamint and Black Mountains, the boundary consists of the frontal faults along the Black Mountains. These faults, like the Black and Panamint Mountains and intervening central Death Valley, trend about $350^{\circ}$; but kinematic indicators along the Black Mountains front indicate the valley side to have moved obliquely northwestward away from the Black Mountains, not directly westward. In northern and southern Death Valley, by contrast, there are no active frontal faults, and the east limit of present major deformation is defined by active right-slip faults well out in the valleys-the Furnace Creek fault zone in the north, Death Valley fault zone in the south. These faults trend northwestward and end approximately at the north and south ends of the Black Mountains frontal-fault system. The northwest-trending strike-slip 
faults are thus transform faults to the extension recorded by the oblique slip on the north-trending Black Mountains frontal faults. Ranges to the west of Death Valley are moving northwestward relative to the region to the east.

\section{Northern Death Valley}

A gentle gravity gradient slopes southwestward from the trace of the detachment fault along the southwest side of the central Funeral Mountains (Chapman and others, 1971; Mabey, 1963), and I infer that the inactive detachment fault continues with gentle southwest dip, beneath an upper plate of deformed Neogene materials, for 8 to $10 \mathrm{~km}$ southwest from the fault trace. At that distance, where the likely depth to the detachment is 2 or $3 \mathrm{~km}$, exposed late Neogene strata are broken by the active, northwest-trending, right-slip Furnace Creek fault (Hunt and Mabey, 1966; L.A. Wright and B.W. Troxel, unpublished map). Gravity gradients steepen slightly across that fault to define the east side of the Death Valley axial low east of Tucki Mountain; the gravity gradient that defines the west side of this low is more gentle. To the west of the northern Funeral Mountains and southern Grapevine Mountains, the gravity gradient across the strikeslip fault is steeper, and it continues into the deep Mesquite Flat gravity low north of Tucki Mountain. The gravity gradients may indicate that the bedrock floor of Death Valley deepens across the strike-slip fault, either by a step or steps or with average slopes steeper than those close to the Funeral Mountains; or they may indicate that the average age and density of Neogene materials above the basement decrease across the fault which marks the east limit of late Pliocene and Quaternary extension of Death Valley.

The southeast end of the Furnace Creek strike-slip fault, at least as a late Quaternary structure, is at the north end of the active, north-trending, oblique-slip Artist's Drive fault that defines the front of the northern Black Mountains. The strike-slip fault is a transform to oblique slip on the normal fault, and the $315^{\circ}$ trend of the strike-slip fault is the direction of modern motion of the Cottonwood Mountains relative to the Funeral and Black Mountains. The Argus Range and Inyo Mountains are in turn moving northwestward relative to the Cottonwood Mountains, as discussed below.

The Furnace Creek strike-slip fault is commonly assumed to continue southeastward, past the Artist's Drive fault, to become the frontal fault of the Funeral Mountains, with which it is aligned; but the Funeral Mountains frontal fault has long been inactive (McAllister, 1970), and its late Pliocene motion had a large vertical component. Perhaps the two sectors shared Pliocene slip, but certainly only the sector within Death Valley is now active.

The Panamint and Cottonwood Mountains and Argus Range all trend about $350^{\circ}$, whereas the direction of their rapid late Neogene relative slip past and away from each other and the Black and Funeral Mountains is about $315^{\circ}$. The aggregate amount of extension in this direction increases both north-northwestward, as successive ranges move away from each other, and westward across it, as adjacent ranges are separated by strike-slip and oblique-slip faults. Such oblique motion cannot be explained in terms of the simple sliding of upper plates down the dip of normal faults inclined deep into the crust, a matter discussed later.

B.P. Wernicke (oral commun., 1987) told me that the Paleozoic and middle Miocene structural and stratigraphic assemblage of the northeasternmost Panamint Mountains is so similar to that of the southeasternmost Funeral Mountains that these blocks likely were adjacent and on north-south strike in middle Miocene time. The indicated $50 \mathrm{~km}$ of relative motion of the Panamint Mountains away from the Funeral Mountains, in the net direction of $305^{\circ}$, took place by some combination of sliding down the ramp fault equivalent to the west flanks of the Funeral Mountains and Black Mountains detachments, by motion of the Black Mountains away from the Funeral Mountains, and by the opening of Death Valley.

\section{Central Death Valley}

The active structures that at the surface bound central Death Valley, between the Panamint and Black Mountains, are the frontal faults of the Black Mountains (fig. 5.14). Those faults, like the valley itself and the flanking ranges, trend about $350^{\circ}$, but kinematic indicators show upper blocks to have moved obliquely northwestward on at least some of the faults.

That central Death Valley has opened by motion of the Panamint Mountains obliquely northwestward away from the Black Mountains is indicated also by the transform relation to the strike-slip Death Valley fault zone in the south. This active strike-slip fault, which offsets late Pleistocene materials, trends northwestward to end approximately at the southward projection of the Black Mountains frontal faults (Wright and Troxel, 1984).

Stewart (1983) argued, on the basis of isopachs and facies of miogeoclinal Late Proterozoic and lower Paleozoic strata, that the Panamint Mountains upper plate had moved $80 \mathrm{~km}$ relatively northwestward, above the Black Mountains on the Amargosa and turtleback detachment faults and across the full width of Death Valley on unspecified structures, from an initial position against the Resting Spring Range. The mylonitic and brecciated carapaces of Late Proterozoic rocks left on the Black Mountains detachment faults are remnants from the passage of the Panamint block, and the block of Late Proterozoic strata near Jubilee Pass in the Black Mountains is a fragment left behind. The Amargosa, turtleback, and Hanaupah detachment faults presumably are parts of the surface or surfaces upon which this $80 \mathrm{~km}$ of slip occurred. Great additional motion of the Resting Spring rocks away from the continental interior is required by other extensional structures farther east. 


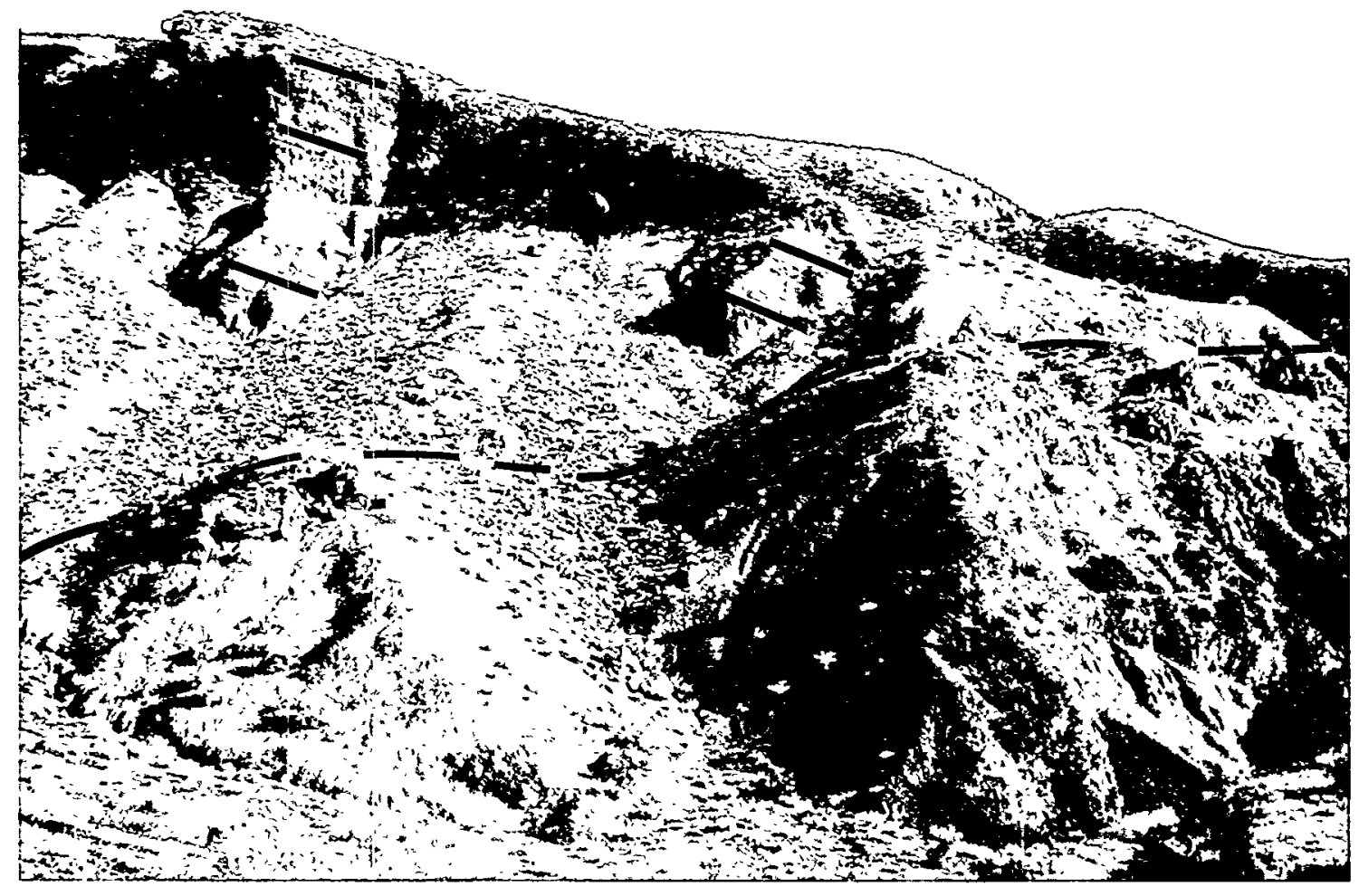

$A$

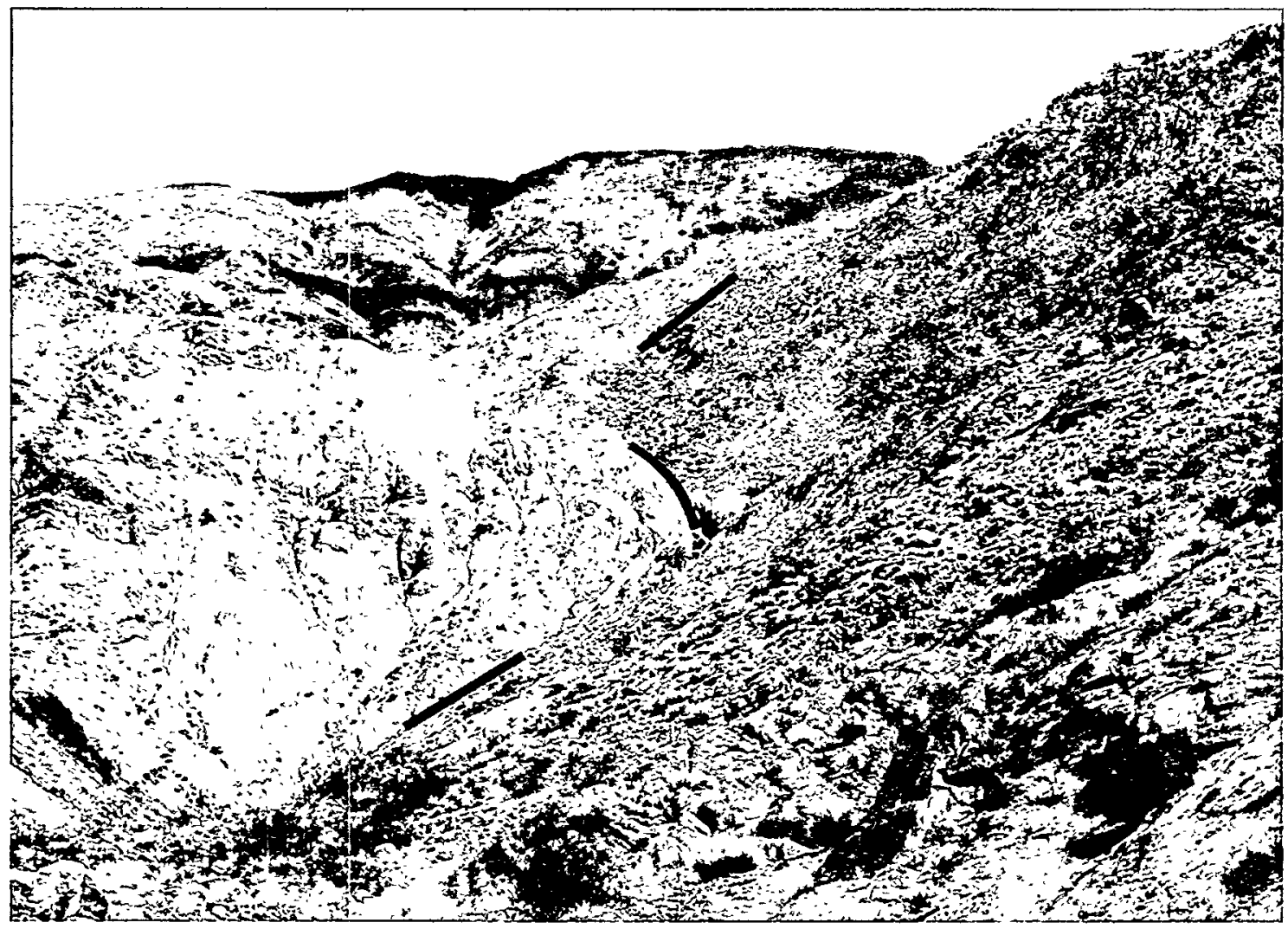

B

74 Geologic and Hydrologic Investigations, Yucca Mountain, Nevada 
The Panamint Mountains have probably moved about $50 \mathrm{~km}$ west-northwestward relative to the upper plate of the southern Funeral Mountains, as noted previously; the upper plate of the Funeral Mountains had in turn moved relatively westward across the lower plate.

The physiography of central Death Valley indicates rapid eastward tilting (Hunt and Mabey, 1966). Along the turtlebacks sector, playa deposits and the evaporites of a latest Pleistocene lake lie in the east half of the valley, their surface as much as $85 \mathrm{~m}$ below sea level, and in places reach the basal scarps of the Black Mountains. These materials were tilted eastward as much as $6 \mathrm{~m}$ in late Holocene time, probably coseismically with the development of the young scarp along the Artist's Drive fault (Hunt and Mabey, 1966). The west half of this sector of the valley is formed of alluvial fans rising to an altitude of $400 \mathrm{~m}$ or so along the unbroken foot of the Panamint Mountains.

Gravity data indicate that low-density Neogene materials are probably nowhere deeper than $3 \mathrm{~km}$ beneath central Death Valley and that the structural axis lies about 40 percent of the way between the Black and Panamint Mountains (Hunt and Mabey, 1966; Mabey, 1963). The average

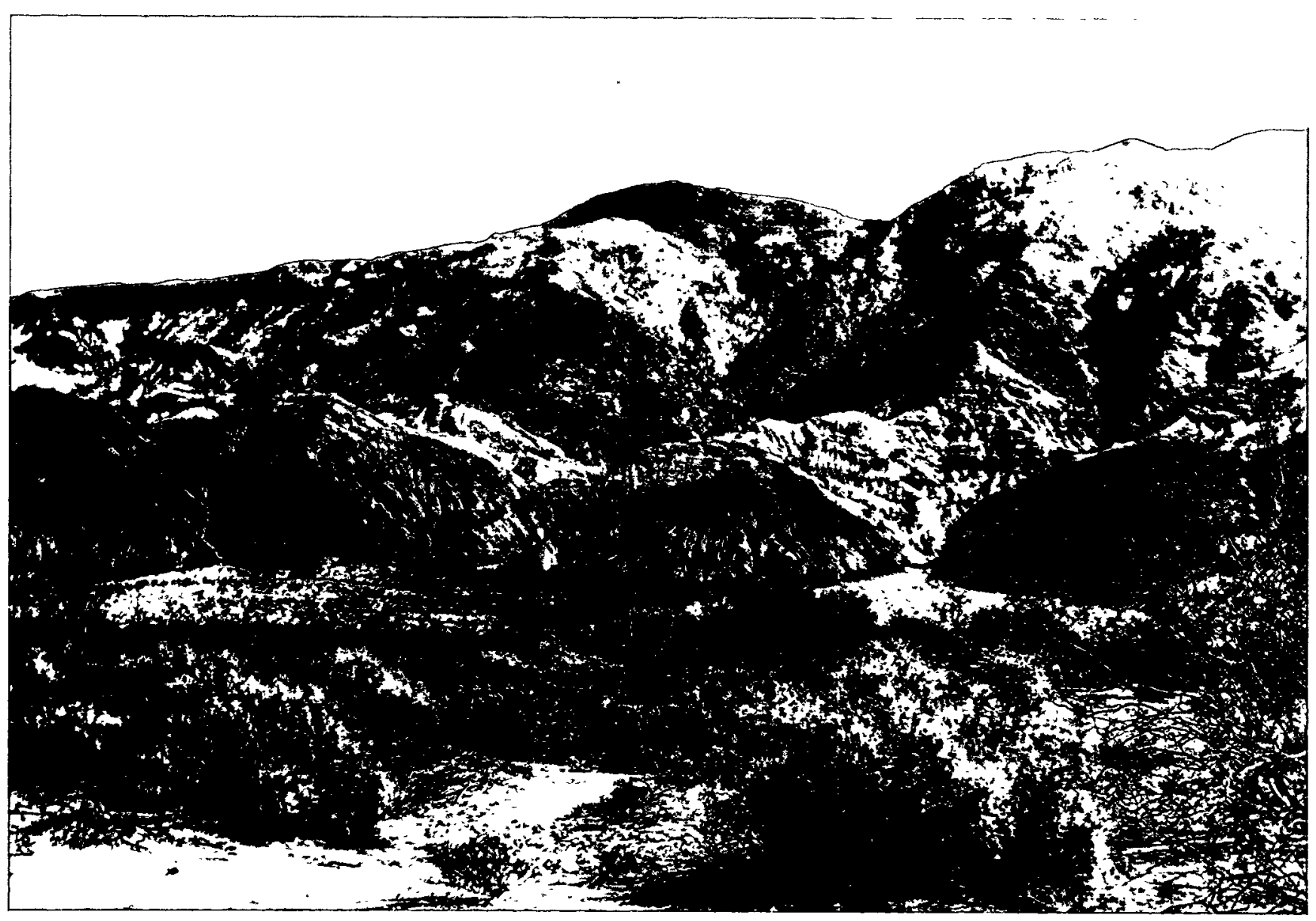

C

Figure 5.13. Tucki detachment fault on west side of Panamint Mountains. A, Detachment fault (dashed line) in lower Wildrose Canyon. Upper Pliocene or lower Pleistocene fanglomerate dips (black lines) southeastward into northwest-dipping fault. Lower plate consists of dark, metamorphosed Late Proterozoic Kingston Peak Formation, in which shearing parallel to the fault and alteration (lightening) can both be seen to increase upward toward the fault. Lower plate has thin carapace of mylonitized marble (light; best exposed across ridge right of center) about $2 \mathrm{~m}$ thick. $B$, Tucki detachment fault (marked by lines), a normal fault rotated to gentle dip. Stripped fault surface (smooth bedrock slope, right and foreground) concordantly tops mylonitized Mesozoic muscovite granite and dips $30^{\circ}$ west. Light-colored
Pliocene or Pleistocene landslide megabreccias of granite and metasedimentary rocks (skyline ridge, and nearby bluff on left) dip $20^{\circ}$ east into fault. Fault had an early history of deep-seated motion, and a late history as a range-front fault with $3 \mathrm{~km}$ of slip; fault and breccias rotated $25^{\circ}$ down to east. Jail Canyon. $C$, Rotated normal fault being exhumed as an apparent rangefront fault. Stripped fault surface forms smooth bedrock face in upper slopes left of canyon, and crests of steep ridges right of canyon. Nonresistant slide megabreccias of the hanging wall form frontal hills and dip moderately back to truncation against fault but have been eroded from higher levels. View east at Hall Canyon. 
slope of the structural or stratigraphic base of all Cenozoic materials-including both variably deformed upper-plate upper Neogene strata and undeformed valley fill-into the deepest part of the structure is near $20^{\circ}$ on the west side of the valley and $35^{\circ}$ on the east side. The east subsurface boundary cannot be a single steep range-front fault; it could be a series of step faults or the downdip continuation of the turtleback faults or a combination of steep and gentle faults, such as are, indeed, exposed in the Badwater sector of the range front. The western subsurface boundary of the valley slopes more gently than the average dip, $40^{\circ}$ or so (Hunt and Mabey, 1966), of the east flank of the tilted Panamint block, hence is unlikely to be the eastward continuation of the exposed contact between Paleozoic and cotilted Miocene strata.

The east side of the Panamint Mountains is close to the stripped contact between resistant east-dipping Paleozoic strata and the more easily eroded Miocene rocks that overlie them semiconcordantly, and both are truncated downward against the Hanaupah detachment fault exposed locally at the foot ofthe range. Gravity data preclude the presence beneath Death Valley of a large panel of tilted Neogene materials, and likely the shallow high-density floor of the west side of the valley consists largely of rocks that are lower plate with regard to the Hanaupah fault. No late Quaternary deformation other than tilting is required by available data for the west side of the valley and the adjacent east base of the Panamint Mountains.

The continuing Quaternary extension of this sector of Death Valley may be accommodated by slip on a fault that dips westward from the west base of the Black Mountains. The continuing eastward tilting of the valley (and the tilting of the entire Panamint Mountains, including the Hanaupah lower plate, as discussed previously) presumably is a product of flattening of this fault. The bedrock surface of the east floor of the valley has an overall slope of only about $35^{\circ}$. If that slope is of the fault surface itself, then the continuation of the fault beneath the west side of the valley and the

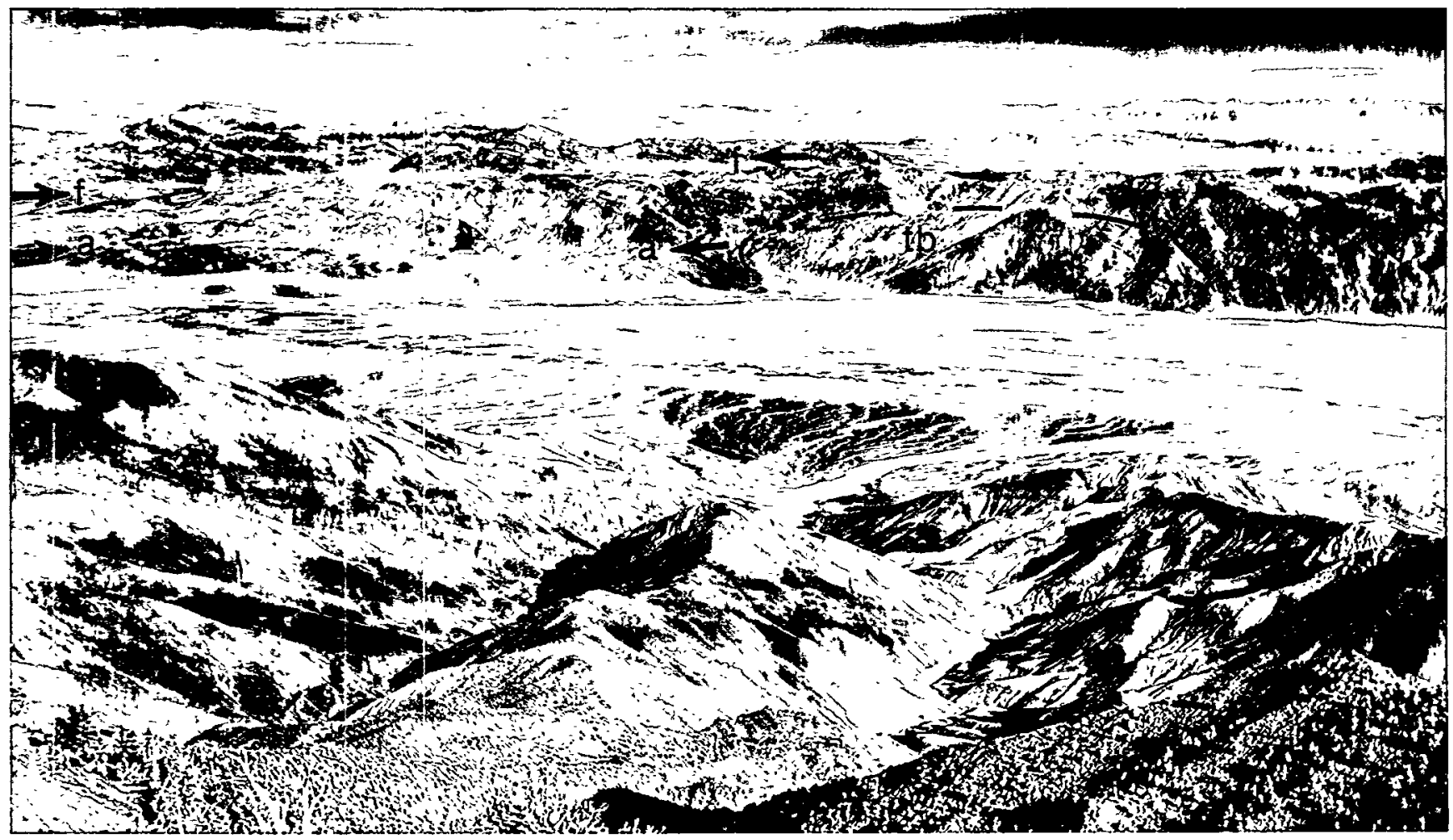

Figure 5.14. View east-northeast across central Death Valley to Black Mountains, from central Panamint Mountains. East-dipping strata of (near) foreground ridges are of Late Proterozoic and (more distant) early Paleozoic ages and are part of Panamint Mountains block. Block is allochthonous above Hanaupah detachment fault and lower-plate gneiss, exposed in low ground near mouth of canyon but not obvious in picture. Late Quaternary Artist's Drive fault (between arrows, a) in Black Mountains ends at right against Badwater turtleback detachment fault (tb; detachment marked by lines). Footwall of Artist's Drive fault is of upper Neogene volcanic and sedimentary rocks; hanging-wall Neogene rocks and Quaternary slide breccias form low hills. Neogene basin fill represented by footwall of Artist's Drive fault forms hanging wall of normal fault (arrows, $f$ ) along southwest front of Funeral Mountains. Large Quaternary normal faults break both turtleback lower plate and, above and right of it, Black Mountains upper plate (which consists of plutonic rocks overlain directly by Neogene volcanic rocks) and outline both parts of range front and canyons in it. Picture taken from Telescope Peak (fig. 5.12A). 
Panamint Mountains is at a very gentle angle; alternatively, the $35^{\circ}$ slope might mark the top of a complex of stepped blocks separated by faults dipping about $60^{\circ}$, and the subPanamint dip could then be perhaps $40^{\circ}$.

This explanation cannot be complete, for it does not account for the obliquity of slip, as is discussed in a subsequent section.

\section{COCORP Seismic-Reflection Profiles}

The Consortium for Continental Reflection Profiling (COCORP) of Cornell University recorded five VIBROSEIS lines in southern Death Valley and the region to the east of it which were processed and interpreted primarily by Beatrice de Voogd and Laura Serpa (de Voogd and others, 1986; Serpa and others, 1985). They inferred a structural style of imbrication by parallel normal faults that dip about $30^{\circ}$ westward and end at subhorizontal detachment faults at a depth near $15 \mathrm{~km}$, along which in one sector is a great sheet of molten basalt. These conclusions are in my view suspect. To enhance possible dipping reflectors, Serpa and de Voogd applied both increased stacking velocities and severe frequency-wavenumber filtering, and they appear to have generated pseudoreflectors, to which they mistakenly attached geologic significance, by so doing. I have studied displays of the five lines as released with their processing. I have studied also COCORP shot gathers and less processed stacks of some of the data, and lines 9 and 11 as reprocessed, without the two suspect procedures, by Eric L. Geist. None of these shows most of the apparent reflectors on which de Voogd and others (1986) and Serpa and others (1985) based their interpretations. The only profile that displays much apparent information even with the COCORP processing, line 11, lies in the narrow south end of Death Valley, only a few kilometers from the front of the Black Mountains; de Voogd and others (1986) and Serpa and others (1985) assumed that all apparent reflections, which are as distant as $6.5 \mathrm{~s}$, are in the vertical plane along the traverse, but complex oblique echoes must in fact be included. Further, the inference of molten magma is in no way required by the acoustic data.

\section{OPENING OF PANAMINT VALLEY}

Panamint Valley, between the Panamint and Cottonwood Mountains on the east and the Argus Range and other mountains on the west, did not begin to form until late Miocene time. Middle late Miocene gravels atop the Darwin Plateau, west of northern Panamint Valley, were derived from the Panamint and Cottonwood Mountains and were deposited on a surface of low relief (Schweig, 1985). Late Miocene basalts, about 6 to $8 \mathrm{~m}$.y. old, predate all, and early Pliocene basalt most, of the tilting and faulting of the Cottonwood Mountains, Darwin Plateau, and Argus Range
(Larsen, 1979; Schweig, 1985). These basalts are in high fault blocks in the Argus Range, are tilted and step-faulted down the east flank of Darwin Plateau into northern Panamint Valley, and reappear in tilted fault blocks on the west face and crest of the Cottonwood Mountains (Hall, 1971; Larsen, 1979; Schweig, 1985). Faults and dikes within the Darwin Plateau indicate that internal extension was mostly west-northwestward, oblique to the range trend of about $345^{\circ}$ (Schweig, 1985). Extension in and between these western ranges is still at a youthful stage; range-sized blocks have not yet been rotated steeply, nor are major gently dipping faults exposed.

The direction of relative motion of the Darwin Plateau away from the Cottonwood Mountains is approximately defined as west-northwestward by the strike-slip fault that trends $300^{\circ}$ between them out of the northwest end of Panamint Valley. The post early Pliocene right slip on this fault has been 8 or $10 \mathrm{~km}$, as constrained by the offset of a piercing point of lower Pliocene basalt above the margin of a large Jurassic pluton (Burchfiel and others, 1987). Restoration of this slip closes northern Panamint Valley so that the preQuaternary rocks now exposed on the two sides are almost juxtaposed.

The Cottonwood Mountains in turn have slipped away from the Panamint Mountains, above the Tucki detachment fault discussed previously. The Pliocene section that dips east-southeastward to a truncation downward against that exposed fault in the northwestern Panamint Mountains is marked by only a slight gravity low (Mabey, 1963), hence likely the Tucki detachment fault continues northwestward with gentle dip beneath the Pliocene rocks. The Pliocene section is the top of the large tilted and complexly faulted Cottonwood Mountains panel, which thus also is allochthonous above faults of the Tucki system. If the azimuth of relative slip of the Cottonwood panel away from the Panamint Mountains was perpendicular to the strike of the tilted Pliocene strata, then that slip was toward about $285^{\circ}$. Southeastern Cottonwood Paleozoic rocks could have been offset from the updip projection of rocks of the main Panamint block $20 \mathrm{~km}$ or more to the east-southeast. Restoration of such an offset makes the upper-crustal Hunter Mountain batholith in the Cottonwoods the shallow, outspread part of the Jurassic plutonic complex whose middle-crust part was the Skidoo pluton in the Panamint Mountains.

The slip of the Argus Range and Darwin Plateau relatively away from the Panamint Mountains should, ideally, equal the sum of the $20+\mathrm{km}$ of slip of the Cottonwoods from the Panamints plus the $10 \mathrm{~km}$ of strike slip of the Darwin Plateau past the Cottonwoods, or $30 \mathrm{~km}$ toward the west-northwest. Although an accurate determination is precluded by large uncertainties, the true value likely is indeed greater than the $18 \mathrm{~km}$ width of central Panamint Valley as measured along the direction of slip. The east part of the present Argus Range block, which consists of uppercrustal granite and contact-metamorphic wallrocks, may have lain above the above the high-grade metamorphic rocks of 
the west-central Panamint Mountains before Pliocene extension rather than adjacent to them; of course, the Panamint block itself moved a long distance, above other detachment faults, relative to assemblages farther east.

The Argus Range thus is part of the upper plate that slid above the detachment fault now exposed along the west side of the Panamint Mountains.

Panamint Valley is marked by a broad, shallow gravity low of such low relief and gentle flank gradients that lowdensity materials probably extend no deeper than $1 \mathrm{~km}$ within it and cannot be bounded by high, steep bedrock contacts (Jones and others, 1987; Mabey, 1963). A well in central northern Panamint Valley penetrated $115 \mathrm{~m}$ of unconsolidated clastic sediments and bottomed in Paleozoic limestone, without intervening basalt (Smith and Pratt, 1957). Magnetic anomalies preclude the presence of Neogene basalt beneath most of the valley (Jones and others, 1987). The shallow, subhorizontal bedrock floor of Panamint Valley may consist largely of rocks that were beneath detachment faults in early Pliocene time, rather than being the trailing parts of plates above such detachment faults.

Extension is continuing at least along the west base of the central Panamint Mountains, where Pleistocene alluvial fans are offset as much as $200 \mathrm{~m}$ vertically on normal faults marked by little-eroded scarps (Albee and others, 1981). The surface of central Panamint Valley is tilted eastward, and a large playa lies close to the Panamint front; a 300-m-deep well in the playa penetrated only evaporites and unconsolidated clastic sediments (Smith and Pratt, 1957). Slight eastward tilting of a Panamint Valley bedrock panel pulled away from relatively minor range-front faults may be indicated, but major steep normal faults are precluded by the gravity data. The active faults lie only 2 to $4 \mathrm{~km}$ west of the trace of the western Panamint detachment fault; if the steep faults end downward at the detachment, then the subsurface part of that gently dipping structure is still active. Although dating of progressive deformation within short time intervals is much needed, it appears likely that the opening of Panamint Valley took place largely during Pliocene time, and that Quaternary extension has been of much lesser amount.

\section{EXTENSION WEST OF PANAMINT VALLEY}

West of the area shown in figure 5.2, a mountainous tract $50 \mathrm{~km}$ or so wide has undergone considerable internal fragmentation by normal faults, but only local tilting, and is bounded in turn by through-going Owens Valley, beyond which is the great raised and slightly tilted block of the Sierra Nevada. The extension within this region almost wholly postdates basalt of early Pliocene age (Duffield and others, 1980; Elliott and others, 1984; Larsen, 1979; Novak and Bacon, 1986; Schweig, 1985). The separation of the Sierra Nevada from ranges to the east and most of its rise to present high altitudes was of late Neogene age (references in Jones,
1987). Structures are seen at high crustal levels, and I know of no detachment faults exposed within this western region. Oblique- and strike-slip faults and the rotation directions of domino-block complexes indicate the general direction of extension to be northwestward relative to the Death Valley region.

\section{EXTENSION SOUTH OF THE DEATH VALLEY REGION}

The Death Valley-Panamint Valley-Owens Valley region of severe late Miocene through Quaternary extension is bounded on the south by the active left-lateral Garlock fault. South of the Garlock fault is the Mojave Desert, at least the eastern part of which was much extended within Oligocene through middle Miocene time; younger activity has been dominated by right slip on northwest-trending faults. The Garlock fault serves as a transform fault by which the northern region, Death Valley to Owens Valley, of active extension is bounded against the southern Mojave region of little young extension (Davis and Burchfiel, 1973; Hamilton and Myers, 1966). From its origin south of the Black Mountains, the Garlock fault trends westward across the south end of the Panamint Mountains, then curves west-southwestward and southwestward to become the south terminus of the Sierra Nevada. Slip on the fault increases from zero at its origin through a well-constrained $60 \mathrm{~km}$ in its middle sector; if the Pelona Schist of the southernmost Sierra Nevada and the Rand Schist of the northwest Mojave Desert are offset parts of an early Paleogene regional anticline, as I infer them to be, then slip in the west is about $100 \mathrm{~km}$. The westwardincreasing offset on the Garlock fault is equal to about half the width of the sectors to the north as measured from the fault origin, so the northern region has been doubled in width within late Miocene through Quaternary time. The Panamint Mountains, Black Mountains, and palinspastically adjacent Mojave Desert all underwent middle Tertiary extension also, and in that sector the 100 percent extension applies only to the subsequent deformation.

Late Neogene extension to the north of the Garlock fault has been in a generally northwestward direction relative to the continental interior, and northwest-trending right-slip faults cross the Mojave Desert. The Garlock fault has rotated clockwise, as though about a pivot at its east end, relative to the continental interior, as slip on it progressed; the initial fault had a much more northerly trend than does the modern one.

\section{EXTENSION EAST OF THE DEATH VALLEY REGION}

The southeastern Great Basin, a terrane $240 \mathrm{~km}$ wide between the area shown in figure 5.2 and the west margin of the little-faulted Colorado Plateau, was extended severely during late Oligocene and early and middle Miocene time. 
Prior to extension, this region was part of the Sevier belt of eastward-imbricated thrust sheets of pre-Tertiary strata. Tertiary strata deposited early in the extensional history of a given sector tend to be broadly concordant to underlying pre-Tertiary strata, and the old rocks as well as the early syntectonic Tertiary strata mostly now dip moderately to steeply eastward. This generally eastward tilting of upperplate blocks, including those in the Death Valley region, indicates that the extensional faults by which they were dismembered mostly had initial westward dips. Local rotation of upper plates to eastward dips can result from slip above downward-flattening west-dipping faults, whereas regional tilting is most easily explained as due to rotation toward the horizontal of a more planar west-dipping fault together with its upper- and lower-plate complexes (Wernicke, 1985).

Extension in the northeastern part of the southeastern Great Basin, north and east of the latitude and longitude of Las Vegas, took place mostly during middle Miocene time (Bohannon, 1983). Large imbricate normal faults have been rotated to gentle dips, and one in the Mormon Mountains has been deformed into a broad dome; only shallow crustal levels are exposed beneath the faults, and lower plates consist of nonmetamorphosed Paleozoic strata (Wernicke and others, 1984, 1985).

In the southeastern part of the southeastern Great Basin, south and east of the latitude and longitude of Las Vegas, a tract, $100 \mathrm{~km}$ wide, of Middle Proterozoic plutonic rocks was denuded tectonically by the slipping westward away from the Colorado Plateau of the Spring Mountains (Wernicke and others, 1982, 1984). Middle Miocene volcanic rocks were deposited directly on denuded Proterozoic rocks and themselves subjected to severe extension above detachment faults now widely exposed (Anderson, 1971; Weber and Smith, 1987)-perhaps half of the $100 \mathrm{~km}$ of relative transport of the Spring Mountains occurred during the middle Miocene, and half before. The western part of the lower-plate Proterozoic basement rocks southeast of the Spring Mountains formed at a depth of only about $10 \mathrm{~km}$ (Young and others, 1986), so a single west-dipping protofault cannot be invoked to explain the slip of the Spring Mountains; the detachment faults must represent a number of different rotated imbricate normal faults or a number of midcrust lenses, or both.

The Spring Mountains block, $90 \mathrm{~km}$ wide along the southwest side of the Las Vegas Valley shear zone but only about $50 \mathrm{~km}$ wide perpendicular to that, has remained almost intact, neither tilted nor fragmented, since Sevier belt thrusting (Burchfiel and others, 1974). The facies and thicknesses of upper-plate Paleozoic and Late Proterozoic strata, and the specific imbrications of those by Sevier belt thrust faults, require that the assemblages now strewn across the Nopah, Resting Spring, Funeral, Grapevine, Panamint, and Cottonwood Mountains were closed up against the southwestern Spring Mountains, in part even resting obliquely upon one another, before separation by imbricate extensional faults (Stewart, 1983; B.P. Wernicke, oral commun., 1987). Of the present cross-strike width, $130 \mathrm{~km}$, of these upper-plate complexes, almost $100 \mathrm{~km}$ represents Cenozoic extension. As the Spring Mountains in turn moved about $100 \mathrm{~km}$ relatively away from the Colorado Plateau, about $200 \mathrm{~km}$ of the present distance of $300 \mathrm{~km}$ of the Cottonwood Mountains from the plateau must represent extension.

In the Nevada Test Site in the northwestern part of the southeastern Great Basin, voluminous middle Miocene ignimbrites and caldera complexes were erupted during ongoing extension (Byers and others, 1976; Christiansen and others, 1977). Successively younger middle Miocene units are successively less deformed, but even the oldest of them display only modest extension; dips are mostly gentle, and no large detachment faults are proved to break surface rocks east of Bare Mountain. The middle Miocene ignimbrites bury severely extended older terrane on the north. Thus, just north of the Nevada Test Site, upper Oligocene rocks are tilted with underlying Paleozoic strata to steep dips above normal faults rotated to gentle dips; lower Miocene rocks are less deformed, and middle Miocene ones still less; and upper Miocene rocks are little deformed (Ekren and others, 1971). The much-extended region (Wernicke and others, 1984) between the Nevada Test Site and the eastern terrane of middle Miocene extension likely was also deformed primarily during late Oligocene and early Miocene time, for although rocks of such ages are all but missing in this area, widespread deformation of this age is proved both to the north in Nevada and to the south in California.

The northwest-trending right-slip Las Vegas Valley shear zone is a transform complex of strike-slip faults and oroclines developed between terranes of different extensional patterns (Wernicke and others, 1982, 1984). To the north of the zone, from the Nevada Test Site to the Colorado Plateau, extension was distributed relatively evenly between many allochthonous blocks. To the south, by contrast, the large Spring Mountains block was little extended internally but moved $100 \mathrm{~km}$ westward away from the Colorado Plateau. Aggregate right-slip faulting and oroflexing across the shear zone is zero in the eastern Lake Mead area, increases to a maximum of about $60 \mathrm{~km}$ at the eastern Spring Mountains, and decreases northwestward to perhaps $30 \mathrm{~km}$ at the northwestern Spring Mountains. The latter slip fully affects rocks that may be as old as Oligocene (see Hinrichs, 1968), but it largely predated 13.5 m.y. ago, for ashflows of that age at Yucca Mountain are oroflexed only about $5 \mathrm{~km}$ (Scott and Rosenbaum, 1986).

\section{DISCUSSION}

The southern Great Basin is now $350 \mathrm{~km}$ wide-and at least $200 \mathrm{~km}$ of this represents crustal extension during middle and late Cenozoic time. Oligocene and early Miocene extension affected a broad medial region; middle Miocene extension affected this same region and also an additional 
region to the east; late Miocene extension affected primarily the far western part of the previously deformed terrane; Pliocene and Quaternary extension has affected in turn the western part of that sector plus a broad area of new deformation to the west of that. The average rate of extension has been about $7 \mathrm{~km}$ per million years, or $7 \mathrm{~mm}$ per year. Extension was concentrated within less than half the width of the widening province at any one time, and strain within a broad tract of active extension likely was on the order of 10 or 20 percent per million years.

Evidence for this amount of extension comes from many criteria. Matching of offset assemblages, and the constraints of transform faults, were emphasized in the preceding descriptions. Half the width of upper-plate rocks now lying against detachment faults consists of basin-fill materials that did not exist when extension began, and this by itself requires 100 percent extension. Palinspastic reconstructions of Mesozoic components in the cordillera make sense to me only in terms of Cenozoic extension on the order of 100 percent (Hamilton, 1978; Hamilton and Myers, 1966).

This extreme extension has been accommodated on structures of different types at different levels in the crust. The brittle structures of the upper crust-normal faults and rotated blocks-are seen to end downward against detachment faults that now have undulating surfaces, and many of these faults are seen to have originated as ductile faults in the middle crust. Rocks which formed the brittle upper crust before this extension began are now stranded as allochthonous, rotated blocks atop undulating detachment faults. Between these upper-plate blocks are rotated middle and upper Cenozoic sedimentary and volcanic rocks, within which tilting commonly decreases stratigraphically upward-deposition and extension were concurrent. Upperplate rocks have mostly been rotated to eastward dips, so the faults that dismembered them mostly had initial westward dips; those faults have been rotated with the blocks and now dip gently.

The conventional assumption that basin-range structure is dominated by tilted bedrock panels, the high part of each forming a mountain range and the low part lying beneath a basin, in contact with one another at range-front faults, is largely invalid for the southern Great Basin. It is invalid also for the Mojave Desert, southeastern California, and southern Arizona, although it may be applicable to restricted parts of the northern Great Basin. Such deformation is uncommon at the large scale of ranges and basins. Ranges instead are mostly allochthonous perched blocks or exposures of subdetachment complexes. Also invalid are any models which require that major faulting related to now-domiform detachment faults represented sliding down the flanks of such domes; late, shallow deformation may indeed have such an origin, but major slip on the structures is independent of direction of present dip of the exposed surfaces. Above all the detachment-fault domes of the Death Valley region, upper-plate strata display a general regional rotation to eastward dips, and hence a consistent slip relatively westward across what are now oppositely dipping flanks of the domes. The domes did not extrude upward, shrugging slide masses off their flanks, as some geologists have postulated.

Rocks beneath the detachment faults of the Death Valley region were at midcrustal depths before extension began and rose to the surface as tectonic denudation removed overlying materials. Early deformation on the deeper parts of the lower plates was ductile, but late slip was at low temperature. Twenty kilometers of crustal section is missing across much of the Funeral Mountains-Bullfrog Hills detachment fault, and likely as much across the Hanaupah fault, where the upper plates are of Tertiary rocks, although those Tertiary rocks have slid far less on the faults than did bedrock upper plates. Favorably oriented detachments remain active even at the surface where upper plates are sliding into presently widening basins.

Many detachment faults studied elsewhere in the Basin and Range province have similarly evolved from zones of ductile slip, initially 10 to $25 \mathrm{~km}$ deep, through progressively less ductile regimes, to final zones of shallow, lowtemperature, brittle slip (Anderson, in press; Davis and Lister, in press; Davis and others, 1986). Many of the faults show a temporal progression from early mylonite through coherent microbreccia to late gouge, which corresponds to a decrease in temperature of deformation from above $300^{\circ} \mathrm{C}$ for quartzose mylonites (Sibson, 1983) to near-surface temperatures for the final gouge. Where early ductile deformation resulted in formation of mylonitic gneiss, temperatures were above $500{ }^{\circ} \mathrm{C}$ (Anderson, in press; Sibson, 1983), and this may have been the case beneath the turtleback detachment faults of the Black Mountains and the Hanaupah detachment fault of the Panamint Mountains. As extension progressed to 100 percent at strain rates such as the 10 or 20 percent per million years noted above for the southern Great Basin, the isotherms limiting ductile behavior would have risen to depths on the order of 60 percent of their initial depths (England and Jackson, 1987), so the shallow limit of ductile deformation rose as tectonic denudation progressed but lagged behind the uplift of the faults. Although the discrimination between mylonites that represent early detachment slip and mylonites that are old structures reused by young shear systems is often ambiguous, there are a number of cases now known in which middle Tertiary granite, little older than the detachment faults that cut them, display severe mylonitization and even mylonitic gneissification. Rises of lower plates by 10 to $20 \mathrm{~km}$ in times as short as a few million years, hence local extension rates that may exceed $1 \mathrm{~cm} / \mathrm{yr}$, seem indicated (Davis and Lister, in press).

Some detachment faults elsewhere in the Basin and Range province have upper-crustal rocks in their footwalls as well as their hanging walls and can be demonstrated to have cut downward through the upper crust with initial moderate to gentle dips and to have been rotated to still gentler dips or to subhorizontal or domiform configurations. Such a fault was tracked, in excellent seismic-reflection records in west-central Utah, from near-headwall outcrop 
to a depth of about $12 \mathrm{~km}$ by Allmendinger and others (1983). Wernicke and others $(1984,1985)$ demonstrated such uppercrustal detachment faulting by geologic mapping in the southeastern Great Basin.

Wernicke (1985) argued that exposed detachment faults are raised parts of great normal faults that originated as ramps cutting gently through the entire lithosphere. He reasoned that imbricate upper-plate normal faults sole downward into such master faults, which are flattened and raised toward the surface by isostatic response to tectonic denudation. The west-northwestward increase in probable depth of metamorphism in the Bullfrog Hills-Bare Mountain-Funeral Mountains lower-plate complex accords with the inference that it was raised from beneath a continuous inclined surface. That same detachment system appears to record a cessation of slip progressing westward with time, and the corresponding progressive stranding of allochthonous blocks at shallow levels; this can be explained as due to the westward progression of the hinge between risen, inactivated sectors of the master fault from still-dipping, active sectors.

Davis and others (1986) applied the Wernicke model to a middle Tertiary detachment fault in southeastern California and another in southeastern Arizona and showed that slip on ductile, semiductile, and brittle components of the nowundulating detachment systems was all in the same downdip sense, in terms of the model. Howard and John (1987) applied the model to detachment faults exposed in the lower Colorado River region, where the structures cut deeply into middle-crust rocks and where the indicated master faults dip toward and beneath the Colorado Plateau, not away from it as in the southern Great Basin. Howard and John demonstrated that the detachment faults obliquely truncated thick crustal sections, in both upper and lower plates, in the sense required by the model; they also showed that major anastomosing or imbricate faults had originated in the middle crust, not just a single master fault.

Much of the deformation observed in the Death Valley region and elsewherein the Basin and Range province is accounted for by the Wernicke model. The complications must be added that different master faults have operated sequentially or simultaneously within each region, that lower plates are themselves broken by new master faults, and that the faults anastomose at depth. Further, the dating of termination of slip on different sectors of a single master fault indicates that the uplift of a lower plate occurs progressively, and that a migrating hinge separates dipping sectors on which slip continues from flattened or undulating sectors on which it has ended. Allochthonous blocks thus become stranded at progressively later times as that hinge migrates beneath them. The aggregate slip of any one allochthon is a function of the duration of its slippage. Stranding occurred about $11 \mathrm{~m} . \mathrm{y}$. ago at Bare Mountain, 7 m.y. ago in the Bullfrog Hills and northeastern Funeral Mountains, 4 m.y. ago in the southwestern Funeral Mountains and eastern Black.Mountains, and 2 m.y. ago in the medial Black Mountains; it has yet to occur in and west of Death Valley.
Wernicke visualized the plates above master ramp faults as greatly disrupted by distributed extension but the plates below them as unbroken. Much extension is in fact required within the lower plates. The many gently dipping normal faults within Bare Mountain, for example, indicate much extension there. Major ductile or semiductile faults within the lower plates have not yet been proved within the Death Valley region but have been identified beneath ductile detachment faults elsewhere in the Basin and Range province (Hamilton, 1987; Howard and John, 1987).

Further, the behavior of the deep crust, although still poorly understood, is unlikely to be that of the Wernicke model. Although Wernicke proposed that the inclined master faults cut completely through the lithosphere, continuity through the deep crust and upper mantle is improbable. Heat flow in much of the Great Basin requires temperatures at the base of the crust near those of granite melts; distinct faults could not be maintained under such conditions. A transition at some depth between structures dominated by unidirectional slip above and by ductile flattening below is to be expected on rock-mechanic grounds (England and Jackson, 1987). Such flattening should occur in discrete zones at relatively shallow depths but be more pervasive at greater depths (Kirby and Kronenberg, 1987). The upper mantle, by contrast, should display much less ductile behavior because of the much greater strength of olivine-rich rocks than of quartzofeldspathic rocks. Extension within lower plates in the southern part of the Basin and Range province, when they were still at high temperatures and considerable depths, produced thick zones of mylonitic gneiss, not merely ductile faults (Davis and Lister, in press). Basal-crustal reflectors, as tracked continuously across much of Nevada in reflection profiles, are unbroken by steps such as predicted by Wernicke (Klemperer and others, 1986). That deep reflection discontinuity is a zone, some kilometers thick, of intercalated rocks of sharply contrasted acoustic properties; rebuilding of attenuated lower crust by sheets of gabbro melted in the mantle can be inferred.

Many seismic-reflection profiles in southeastern California and southern Arizona show the crust beneath undulating detachment faults to display large lenses of acoustically transparent rock between anastomosing zones of gently dipping reflectors that presumably record layering due to transposition by ductile flow (Hamilton, 1982, 1987; Morris and others, 1986; Okaya and Frost, 1986a, b; Okaya and others, 1986). More pervasive, subhorizontal reflection fabrics appear to typify the deeper crust. The lenses characterize what is now the upper part of the subdetachment crust, but as the rocks exposed beneath such detachment faults mostly originated in the middle crust, the lenses are developed in what was middle crust before extension. Profiles in the northern Great Basin similarly show a lower crust characterized by subhorizontal reflectors, and a middle crust that appears to display discontinuous, gently dipping zones of reflectors (Allmendinger and others, 1987; Potter and others, 1987).

Detachment Faulting in the Death Valley Region 
I deduced from the presence of such lenses and from the geometry I perceived in the midcrust rocks exposed beneath detachment faults in southeastern California and southwestern Arizona a model of extensional deformation dominated by the spreading apart of lenses between zones of ductile shear, rather like the gravitational spreading of a pile of wet fish (Hamilton, 1982, 1987). This model resembles in important aspects that of G.H. Davis (1980), but not of his later work (1983). I viewed most detachment faults as the tops of great lenses that are separated by gently dipping,anastomosing ductile faults and that retain prefaulting fabrics in their interiors. As the lenses slide apart along ductile faults, the area of the composite top of the lensesthe detachment faults-increases. Shallow, brittle materials rotate in collapsing blocks as their substrate is widened, and in part are torn apart and in part are carried passively along on the lenses. Domiform and undulating fault shapes represent primarily deformation due to interactions between moving lenses.

I now see that (as colleagues tried to tell me) rotated great normal faults are much more important than accounted for by my model as just described. Wernicke's (1985) model accounts far better than mine for much of the deformation observed in the field-but his model, beyond its problems with deep-crustal mechanics, also leaves important deformation unexplained, and so cannot yet be complete.

High among the problems is the obliquity of extension in the southwestern Great Basin. Although Death Valley and Panamint Valley and their flanking ranges trend northward or north-northwestward, the relative direction of slip of western ranges away from eastern is northwestward, not westward. The east boundary of major active extension consists of the northwest-trending, right-slip Furnace Creek and Death Valley fault zones and an intervening north-trending oblique-slip fault along the Black Mountains. B.P. Wernicke (oral commun., 1987) suggested that the northwestward motion might be due to a push of upper plates from the south by an impinging Mojave plate. Although the northwestward shift of the massive Sierra Nevada can be visualized in these terms, they would also require that, improbably, the push be transmitted $300 \mathrm{~km}$ northward along the narrow, unshortened block of the Coso, Inyo, and White Mountains, which is moving northwestward with regard to terranes to the east.

The boundary between the North American and Pacific plates is the northwest-trending, right-slip San Andreas fault system. This plate boundary ends at the northern California triple junction with the north-trending Oregon trench and west-trending Mendocino transform fault. The triple junction is migrating northward, relative to the continental interior, at the slip rate of the San Andreas system, yet it is positioned in a zone of sharp change in the trend of the continental margin. Perhaps this is a coincidence, and the margin of North America south of the present triple junction happened to lie parallel to the direction of relative motion of the Pacific plate. It appears to me more likely, consider- ing the patterns of crustal extension within the Western United States, that the shape of the continent is changing as needed to maintain contact with the Pacific plate south of the migrating triple junction. Among the elements of this change might be northwestward drag of components as far east as the Sierra Nevada, and oblique flattening of the deep crust in the Great Basin. Such flattening could be in a separating-lens mode in the middle crust and a more pervasive mode in the lower crust. The oblique extension underway at the surface in the Death Valley region may be a relatively passive response to the progressively more pervasive flattening beneath it.

\section{REFERENCES CITED}

Albee, A.L., Labotka, T.C., Lanphere, M.A., and McDowell, S.D., 1981, Geologic map of the Telescope Peak quadrangle, California: U.S. Geological Survey Geologic Quadrangle Map GQ-1532, scale 1:62,500.

Allmendinger, R.W., and others, 1983, Cenozoic and Mesozoic structure of the eastern Basin and Range province, Utah, from COCORP seismic-reflection data: Geology, v. 11, no. 9, p. 532-536.

Allmendinger, R.W., and others, 1987, Overview of the COCORP $40^{\circ} \mathrm{N}$ transect, Western United States: The fabric of an orogenic belt: Geological Society of America Bulletin, v. 98, no. 3, p. 308-319.

Anderson, J.L., in press, Core complexes of the Mojave-Sonoran Desert-Conditions of plutonism, mylonitization, and decompression, in Emst, W.G., editor, Metamorphic and tectonic evolution of the Western United States: Englewood Cliffs, N.J., Prentice-Hall.

Anderson, R.E., 1971, Thin skin distension in Tertiary rocks of southeastern Nevada: Geological Society of America Bulletin, v. 82 , p. $43-58$.

Armstrong, R.L., 1972, Low-angle (denudation) faults, hinterland of the Sevier orogenic belt, eastern Nevada and western Utah: Geological Society of America Bulletin, v. 83, p. 1729-1754.

Bohannon, R.G., 1983, Mesozoic and Cenozoic tectonic development of the Muddy, North Muddy, and northern Black Mountains, Clark County, Nevada, in Miller, D.M., and others, eds., Tectonic and stratigraphic studies in the eastern Great Basin: Geological Society of America Memoir 157, p. 125-148.

Burchfiel, B.C., Fleck, R.J., Secor, D.T., Vincelette, R.R., and Davis, G.A., 1974, Geology of the Spring Mountains, Nevada: Geological Society of America Bulletin, v. 85, p. 1013-1022.

Burchfiel, B.C., Hodges, K.V., and Royden, L.H., 1987, Geology of Panamint Valley-Saline Valley pull-apart system, California-Palinspastic evidence for low-angle geometry of a Neogene range-bounding system: Journal of Geophysical Research, v. 92, p. 10422-10426.

Byers, F.M., Jr., Carr, W.J., Orkild, P.P., Quinlivan, W.D., and Sargent, K.A., 1976, Volcanic suites and related cauldrons of Timber Mountain-Oasis Valley caldera complex, southern Nevada: U.S. Geological Survey Professional Paper 919, 70 p.

Carr, W.J., 1984, Regional structural setting of Yucca Mountain, southwestern Nevada, and late Cenozoic rates of tectonic activity in part of the southwestern Great Basin, Nevada and 
California: U.S. Geological Survey Open-File Report 84-854, $114 \mathrm{p}$.

Carr, W.J., Byers, F.M., Jr., and Orkild, P.P., 1986, Stratigraphic and volcano-tectonic relations of Crater Flat Tuff and some older volcanic units, Nye County, Nevada: U.S. Geological Survey Professional Paper 1323, 28 p.

Cemen, Ibrahim, Wright, L.A., Drake, R.E., and Johnson, F.C., 1985, Cenozoic sedimentation and sequence of deformational events at the southeastern end of the Furnace Creek strike-slip fault zone, Death Valley region, California: Society of Economic Paleontologists and Mineralogists Special Publication 37, p. 127-141.

Chapman, R.H., Healey, D.L., Troxel, B.W., Streitz, R., and Stinson, M.C., 1977, Bouguer gravity map of CaliforniaDeath Valley sheet: California Division of Mines and Geology, scale 1:250,000.

Christiansen, R.L., Lipman, P.W., Carr, W.J., Byers, F.M., Jr., Orkild, P.P., and Sargent, K.A., 1977, Timber Mountain-Oasis Valley caldera complex of southern Nevada: Geological Society of America Bulletin, v. 88, p. 943-959.

Cornwall, H.R., 1972, Geology and mineral deposits of southern Nye County, Nevada: Nevada Bureau Mines and Geology, Bulletin 77, 49 p.

Cornwall, H.R., and Kleinhampl, F.J., 1961, Geology of the Bare Mountain quadrangle, Nevada: U.S. Geological Survey Geologic Quadrangle Map GQ-157, scale 1:62,500.

1964, Geology of Bullfrog quadrangle and ore deposits related to Bullfrog Hills caldera, Nye County, Nevada and Inyo County, California: U.S. Geological Survey Professional Paper 454-J, 25 p.

Curry, H.D., 1954, Turtlebacks in the central Black Mountains, Death Valley, California: California Division of Mines Bulletin 170 , v. 1, p. 53-59.

Davis, G.A., Anderson, J.L., Frost, E.G., and Shackelford, T.J., 1980, Mylonitization and detachment faulting in the WhippleBuckskin-Rawhide Mountains detachment terrane, southeastern California and western Arizona: Geological Society of America Memoir 153, p. 79-129.

Davis, G.A., and Burchfiel, B.C., 1973, Garlock fault-An intracontinental transform structure, southern California: Geological Society of America Bulletin, v. 84, p. 1407-1422.

Davis, G.A., and Lister, G.S., in press, Detachment faulting in continental extension-Perspectives from the southwestern U.S. Cordillera, in Geological Society of America Special Paper 218.

Davis, G.A., Lister, G.S., and Reynolds, S.J., 1986, Structural evolution of the Whipple and South Mountains shear zones, Southwestern United States: Geology, v. 14, no. 1, p. 7-10.

Davis, G.H., 1980, Structural characteristics of metamorphic core complexes, southern Arizona: Geological Society of America Memoir 153, p. 35-77.

1983, Shear-zone model for the origin of metamorphic core complexes: Geology, v. 11, no. 6, p. 342-347.

de Voogd, Beatrice, Serpa, L., Brown, L., Hauser, E., Kaufman, S., Oliver, J., Troxel, B.W., Willemin, J., and Wright, L.A., 1986, Death Valley bright spot-A midcrustal magma body in the southern Great Valley, California?: Geology, v. 14, p. 64-67.

Drewes, H.D., 1959, Turtleback faults of Death Valley, California-A reinterpretation: Geological Society of America Bulletin, v. 70, p. 1497-1508.
1963, Geology of the Funeral Peak quadrangle, California, on the east flank of Death Valley: U.S. Geological Survey Professional Paper 413, 78 p.

Duffield, W.A., Bacon, C.R., and Dalrymple, G.B., 1980, Late Cenozoic volcanism, geochronology, and structure of the Coso Range, Inyo County, California: Journal of Geophysical Research, v. 85, p. 2381-1404.

Ekren, E.B., Anderson, R.E., Rogers, C.L., and Noble, D.C., 1971, Geology of northern Nellis Air Force Base bombing and gunnery range, Nye County, Nevada: U.S. Geological Survey Professional Paper 651, $91 \mathrm{p}$.

Elliott, G.S., Wrucke, C.T., and Nedell, S.S., 1984, K-Ar ages of late Cenozoic volcanic rocks from the northern Death Valley region, California: Isochron/West, no. 40, p. 3-7.

Emmons, W.H., 1907, Normal faulting in the Bullfrog district: Science, v. 26, p. 221.

Emmons, W.H., and Garrey, G.H., 1910, General geology of the Bullfrog district, Nevada: U.S. Geological Survey Bulletin 407, p. 19-89.

England, Philip, and Jackson, James, 1987, Migration of the seismic-aseismic transition during uniform and nonuniform extension of the continental lithosphere: Geology, v. 15, no. 4, p. 291-294.

Giaramita, M.J., 1984, Structural evolution and metamorphic petrology of the Monarch Canyon area, northern Funeral Mountains, Death Valley, California: Davis, University of California, M.S. thesis.

Hall, W.E., 1971, Geology of the Panamint Butte quadrangle, Inyo County, California: U.S. Geological Survey Bulletin 1299, $67 \mathrm{p}$.

Hamilton, Warren, 1978, Mesozoic tectonics of the Western United States: Pacific Section, Society of Economic Paleontologists and Mineralogists, Pacific Coast Paleogeography Symposium 2, Proceedings, p. 33-70.

1982, Structural evolution of the Big Maria Mountains, northeastern Riverside County, southeastern California, in Frost, E.G., and Martin, D.L. editors, Mesozoic-Cenozoic tectonic evolution of the Colorado River region, California, Arizona, and Nevada-Anderson-Hamilton volume: San Diego, Cordilleran Publishers, p. 1-27.

1987, Crustal extension in the Basin and Range Province, southwestern United States: Geological Society of London Special Publication 28, p. 155-176.

Hamilton, Warren, and Myers, W.B., 1966, Cenozoic tectonics of the Western United States: Reviews of Geophysics, v. 4, p. 509-549.

Hinrichs, E.N., 1968, Geologic map of the Camp Desert Rock quadrangle, Nye County, Nevada: U.S. Geological Survey Geologic Quadrangle Map GQ-726, scale 1:24,000.

Howard, K.A., and John, B.E., 1987, Crustal extension along a rooted system of imbricate low-angle faults-Colorado River extensional corridor, California and Arizona: Geological Society of London Special Publication 28, p. 299-311.

Hunt, C.B., and Mabey, D.R., 1966, Stratigraphy and structure, Death Valley, California: U.S. Geological Survey Professional Paper 494-A, 162 p.

Jennings, C.W., Burnett, J.L., and Troxel, B.W., 1962, Geologic map of California-Trona Sheet: California Division of Mines and Geology, scale 1:250,000.

Jones, C.H., 1987, Is extension in Death Valley accommodated 
by thinning of the mantle lithosphere beneath the Sierra Nevada, California?: Tectonics, v. 6, p. 449-473.

Jones, C.H., and others, 1987, A geophysical investigation of the northern Panamint Valley, Inyo County, California-Evidence for possible low-angle normal faulting at shallow depth in the crust: Journal of Geophysical Research, v. 92, p. 10427-10441.

Kirby, S.H., and Kronenberg, A.K., 1987, Rheology of the lithosphere-Selected topics: Reviews of Geophysics, v. 25, p. 1219-1244.

Klemperer, S.L., Hauge, T.A., Hauser, E.C., Oliver, J.E., and Potter, C.J., 1986, The Moho in the northern Basin and Range province, Nevada, along the COCORP $40^{\circ} \mathrm{N}$ seismic reflection transect: Geological Society of America Bulletin, v. 97, no. 5 , p. 603-618.

Labotka, T.C., 1980, Petrology of a medium-pressure regional metamorphic terrane, Funeral Mountains, California: American Mineralogist, v. 65, p. 670-689.

Labotka, T.C., and Albee, A.L., in press, Metamorphism and tectonics of the Death Valley region, California, in Ernst, W.G., editor, Metamorphism and crustal evolution of the Western United States: Englewood Cliffs, N.J., Prentice-Hall.

Labotka, T.C., Albee, A.L., Lanphere, M.A., and McDowell, S.D., 1980, Stratigraphy, structure, and metamorphism in the central Panamint Mountains (Telescope Peak quadrangle), Death Valley area, California: Geological Society of America Bulletin, v. 91, part I, no. 3, p. 125-129 [Summary], and v. 91, part II, no. 3, p. 843-933.

Larsen, N.W., 1979, Chronology of late Cenozoic basaltic volcanism-The tectonic implications along a segment of the Sierra Nevada and Basin and Range province boundary: Provo, Utah, Brigham Young University, Ph.D. thesis, 95 p.

Mabey, D.R., 1963, Complete Bouguer anomaly map of the Death Valley region, California.. U.S. Geological Survey Geophysical Investigations Map GP-305, scale 1:250,000.

Maldonado, Florian, compiler, 1985, Geologic map of the Jackass Flats area, Nye County, Nevada: U.S. Geological Survey Miscellaneous Investigations Series Map I-1519, scale $1: 48,000$.

McAllister, J.F., 1970, Geology of the Furnace Creek borate area, Death Valley, Inyo County, California: California Division of Mines and Geology, Map Sheet 14, 9 p. + map, scale $1: 24,000$.

1971, Preliminary geologic map of the Funeral Mountains in the Ryan quadrangle, Death Valley region, Inyo County, California: U.S. Geological Survey Open-File Report 71-187, scale 1:31,680.

1973, Geologic map and sections of the Amargosa Valley borate area-southeast continuation of the Furnace Creek area-Inyo County, California: U.S. Geological Survey Miscellaneous Investigations Series Map I-782, scale 1:24,000.

McKee, E.H., 1983, Reset K-Ar ages-Evidence for three metamorphic core complexes, western Nevada: Isochron/West, no. 38 , p. 17-20.

Miller, E.L., Gans, P.B., and Garing, John, 1983, The Snake Range decollement-An exhumed mid-Tertiary ductile-brittle transition: Tectonics, v. 2, no. 3, p. 239-263.

Monsen, S.A., 1982, Structural evolution and metamorphic petrology of the Precambrian-Cambrian strata, northwest Bare Mountain, Nevada: Davis, University of California, M.S. thesis.
Morris, R.S., Okaya, D.A., and Frost, E.G., 1986, Multiple deformational events evident in the regional crustal structure of SE California from industry seismic profiles [abs.]: Eos, American Geophysical Union Transactions, v. 67, p. 1109.

Myers, W.B., and Hamilton, Warren, 1964, Deformation accompanying the Hebgen Lake earthquake of August 17, 1959: U.S. Geological Survey Professional Paper 435-I, p. 55-98.

Noble, L.F., 1941, Structural features of the Virgin Spring area, Death Valley, California: Geological Society of America Bulletin, v. 52, p. 941-999.

Novak, S.W., and Bacon, C.R., 1986, Pliocene volcanic rocks of the Coso Range, Inyo County, California: U.S. Geological Survey Professional Paper 1383, 44 p.

Okaya, D.A., Blakeslee, S.N., Pridmore, C.L., and Frost, E.G., 1986, Crustal-scale geometry of detachment faulting in the Harquahala Mountains region of west-central Arizona [abs.]: Geological Society of America Abstracts with Programs, v. 18, no. 2 , p. 166.

Okaya, D.A., and Frost, E.G., 1986a, Regional tectonic implications of the CALCRUST seismic profiling southwest of the Whipple Mountains, SE California [abs.]: Eos, American Geophysical Union Transactions, v. 67, p. 1109.

1986b, Crustal structure of the Whipple-Turtle-Old Woman Mtns. region based on CALCRUST and industry seismic profiles [abs.]: Geological Society of America Abstracts with Programs, v. 18, no. 2, p. 166.

Otton, J.K., 1977, Geology of the central Black Mountains, Death Valley, California-The turtleback terrane: College Park, Penn., Pennsylvania State University, Ph.D. thesis, 155 p.

Potter, C.J., and others, 1987, Crustal structure of north-central Nevada: Results from COCORP deep seismic profiling: Geological Society of America Bulletin, v. 98, no. 3, p. 330-337.

Reynolds, M.W., 1969, Stratigraphy and structural geology of the Titus and Titanothere Canyons area, Death Valley, California: Berkeley, University of California, Ph.D. thesis, $406 \mathrm{p}$. 1976, Geology of the Grapevine Mountains, Death Valley, California-A summary: California Division of Mines and Geology Special Report 106, p. 19-26.

Schweig, E.S., III, 1985, Neogene tectonics and paleogeography of the southwestern Great Basin, California: Palo Alto, California, Stanford University, Ph.D. thesis, 229 p.

Scott, R.B., 1986, Extensional tectonics at Yucca Mountain, southern Nevada [abs.]: Geological Society America Abstracts with Programs, v. 18 , no. 5 , p. 411.

Scott, R.B., and Bonk, Jerry, 1984, Preliminary geologic map of Yucca Mountain, Nye County, Nevada, with geologic sections: U.S. Geological Survey Open-File Report 84-494, 9 p. + map, scale $1: 12,000$.

Scott, R.B., and Rosenbaum, J.G., 1986, Evidence of rotation about a vertical axis during extension at Yucca Mountain, southern Nevada [abs.]: Eos, American Geophysical Union Transactions, v. 67 , p. 358 .

Scott, R.B., and Whitney, J.W., 1987, The upper crustal detachment system at Yucca Mountain, SW Nevada [abs.]: Geological Society of America Abstracts with Programs, v. 19 , p. 332-333.

Serpa, L., de Voogd, B., Oliver, J., and Wright, L., 1985, Late Cenozoic structural evolution of the Death Valley region from COCORP seismic profiles (abs.): Geological Society of 
America Abstracts with Programs, v. 17, p. 407.

Sibson, R.H., 1983, Continental fault structure and the shallow earthquake source: Geological Society of London Journal, v. 140, p. 741-767.

Smith, G.I., and Pratt, W.P., 1957, Core logs from Owens, China, Searles, and Panamint basins, California: U.S. Geological Survey Bulletin 1045-A, 62 p.

Snyder, D.B., and Carr, W.J., 1982, Preliminary results of gravity investigations at Yucca Mountain and vicinity, southern Nye County, Nevada: U.S. Geological Survey Open-File Report 82-701, 41 p.

1984, Interpretation of gravity data in a complex volcano-tectonic setting, southwestern Nevada: Journal of Geophysical Research, v. 89, p. 10193-10206.

Stern, T.W., Newell, M.F., and Hunt, C.B., 1966, Uranium-lead and potassium-argon ages of parts of the Amargosa thrust complex, Death Valley, California, in Geological Survey research 1966: U.S. Geological Survey Professional Paper 550-B, p. B142-B147.

Stewart, J.H., 1983, Extensional tectonics in the Death Valley area, California-Transport of the Panamint Range structural block $80 \mathrm{~km}$ northwestward: Geology, v. 11, no. 3, p. 153-157.

Swadley, WC, and Carr, W.J., 1987, Geologic map of the Quaternary and Tertiary deposits of the Big Dune quadrangle, Nye County, Nevada, and Inyo County, California: U.S. Geological Survey Miscellaneous Investigations Series Map I-1767, scale $1: 48,000$.

Weber, M.E., and Smith, E.I., 1987, Structural and geochemical constraints on the reassembly of disrupted mid-Miocene volcanoes in the Lake Mead-Eldorado Valley area of southern Nevada: Geology, v. 15, no. 6, p. 553-556.

Wernicke, Brian, 1985, Uniform-sense normal simple shear of the continental lithosphere: Canadian Journal of Earth Sciences, v. 22 , no. 1 , p. 108-125.

Wernicke, Brian, Guth, P.L., and Axen, G.J., 1984, Tertiary extensional tectonics in the Sevier belt of southern Nevada (field trip 19), in Lintz, Joseph, Jr., ed., Western geological excursions, v. 4: Reno, Nevada, Mackay School of Mines, p. 473-510.

Wernicke, Brian, Hodges, K.V., and Walker, J.D., 1986, Geological setting of the Tucki Mountain area, Death Valley National Monument, California, in Dunne, G.C., ed., Mesozoic and Cenozoic structural evolution of selected areas, east-central California: Geological Society of America, Cordilleran Section, Guidebook, Field trips 2 and 14, p. 67-80.

Wernicke, Brian, Spencer, J.E., Burchfiel, B.C., and Guth, P.L., 1982, Magnitude of crustal extension in the southern Great Basin: Geology, v. 10 , no. 10 , p. $499-503$.

Wernicke, Brian, Walker, J.D., and Beaufait, M.S., 1985, Structural discordance between Neogene detachments and frontal Sevier thrusts, central Mormon Mountains, southern Nevada: Tectonics, v. 4, no. 2, p. 213-246.

Wright, L.A., Otton, J.K., and Troxel, B.W., 1974, Turtleback surfaces of Death Valley viewed as phenomena of extensional tectonics: Geology, v. 2, p. 53-54.

Wright, L.A., and Troxel, B.W., 1973, Shallow-fault intepretation of basin and range structure, southwestern Great Basin, in DeJong, K.A., and Scholten, Robert, editors, Gravity and tectonics: New York, Wiley-Interscience, p. 397-407.

1984, Geology of the northern half of the Confidence Hills 15-minute quadrangle, Death Valley region, eastern California-The area of the Amargosa Chaos: California Division of Mines and Geology Map Sheet 34, 31 p. + map, scale $1: 24,000$.

Young, E.D., Clarke, H.S., and Anderson, J.L., 1986, Proterozoic low-pressure hornblende-granulite facies migmatites, McCullough Range, southern Nevada [abs.]: Geological Society of America Abstracts with Programs, v. 18, no. 2, p. 202. 



\title{
6. Stress Field at Yucca Mountain, Nevada
}

\author{
By Joann M. Stock and John H. Healy
}

\section{CONTENTS}

\author{
Abstract 87 \\ Introduction 87 \\ Acknowledgments 87 \\ Stress magnitudes 87 \\ Stress directions 90 \\ Agreement with regional data 91 \\ Topographic effects on the horizontal stress 91 \\ Tectonic implications 92 \\ Conclusions 92 \\ References cited 92
}

\section{Abstract}

Hydraulic fracturing stress measurements performed in four holes (USW G-1, USW G-2, USW G-3, and Ue25P1) indicate that at Yucca Mountain, the least horizontal stress $S_{h}$ is less than the vertical stress $S_{v}$. Values of the greatest horizontal stress $S_{H}$ are intermediate between $S_{h}$ and $S_{v}$, corresponding to a normal faulting regime with values of $\phi=\left(S_{H}-S_{h}\right) /\left(S_{v}-S_{h}\right)$ between 0.25 and 0.7 . Drilling-induced hydraulic fractures seen on borehole televiewer logs indicate an $S_{h}$ direction of N. $60^{\circ} \mathrm{W}$. to N. $65^{\circ} \mathrm{W}$. in USW G-1, USW G-2, and USW G-3. The same $S_{h}$ direction is inferred from breakout orientations in USW G-2 and Ue25P1. The $S_{h}$ values in the upper parts of the three USW $G$ holes are less than the pressure of a column of water filling the borehole to the surface. Thus, the long drilling-induced hydraulic fractures in the shallow parts of these holes could have been formed in attempts to maintain circulation during drilling. These low $S_{h}$ values may be intimately related to the low water table and fracture-dominated hydrology of Yucca Mountain.

\section{INTRODUCTION}

Information on the state of stress at Yucca Mountain is important to the evaluation of its suitability as a site for a high-level radioactive waste repository. A knowledge of the stress field is a key parameter in our understanding of the tectonic setting of the site, and the evaluation of possible failure behavior of preexisting faults. This knowledge permits estimation of the additional stresses which may be induced by the repository, for instance, due to excavation or thermal effects of the waste. Because the magnitudes of the principal stresses influence fluid transport through fractures, the stress field may be intimately related to the hydrologic regime present at Yucca Mountain.
The hydraulic fracturing stress measurements performed at Yucca Mountain, as part of the Nevada Nuclear Waste Storage Investigations program of the U.S. Department of Energy, yield information on the directions and magnitudes of the principal stresses at the locations of the individual tests, made within holes USW G-1, USW G-2, USW G-3, and Ue25P1 (fig. 6.1). When collectively evaluated and combined with other stress field indicators, the results provide an important basis for more detailed studies, with specific reference to the depths being considered for the repository facility.

\section{Acknowledgments}

We thank W.F. Brace, Art McGarr, and Mary Lou Zoback for helpful comments. Hans Swolfs' suggestions were also much appreciated, although he does not endorse all of our conclusions. The field measurements were performed in cooperation with the Nevada Operations Office of the U.S. Department of Energy under interagency agreement DE-AI08-78ET44802. J.M. Stock thanks the Fannie and John Hertz Foundation for supporting her graduate work at the Massachusetts Institute of Technology, during which time this paper was completed.

\section{STRESS MAGNITUDES}

The hydraulic fracturing method directly measures the magnitude of the least horizontal principal stress, $S_{h}$, and indirectly yields an estimate of the value of the greatest horizontal principal stress, $S_{H}$. The method, first proposed by Hubbert and Willis (1957), is now fairly standard and is described in detail elsewhere (see Hickman and Zoback, 1983). Our test procedures and equipment setup are described in more detail by Healy and others (1984) and Stock and others $(1984,1986)$.

This method is based on an analytic solution for stress around a cylindrical hole in an elastic, isotropic medium (Hubbert and Willis, 1957). If $S_{h}$ and $S_{H}$ are perpendicular to the borehole axis, the minimum compressive stress tangential to the borehole occurs at the azimuth of $S_{H}$. Therefore, when the pressure in the holes exceeds this minimum stress, a hydraulic fracture should be formed at this azimuth and propagate perpendicularly to the direction of $S_{h}$. The $S_{h}$ is obtained by observing the normal stress across the newly created hydrofracture, defined as the pressure at which the fracture closes, or the ISIP (instantaneous shut in pressure) 
visible on the pressure-time curves. The $S_{H}$ is calculated from the fracture reopening pressure on the second cycle, according to the method of Bredehoeft and others (1976). The pore pressure, which is needed for the $S_{H}$ calculation, is calculated as the hydrostatic pressure from the observed water level in the hole. If testing has altered the pore pressure, so that its value is uncertain, then $S_{H}$ cannot be well constrained. Because this was the case in many of our tests, few credible $S_{H}$ values were obtained.
The third principal stress must be vertical, and is calculated by integrating the weight of the overlying rocks, obtained from compensated density logs and (or) borehole gravimetry. The compensated density logs, gravimetry (where available), and density measurements of core samples were generally in close agreement for these four holes, so most of the estimates of vertical stress magnitudes are likely to be quite accurate. Where the hole has a large component of drift, such as in the lower part of USW G-3, corrections $116^{\circ} 30^{\prime}$

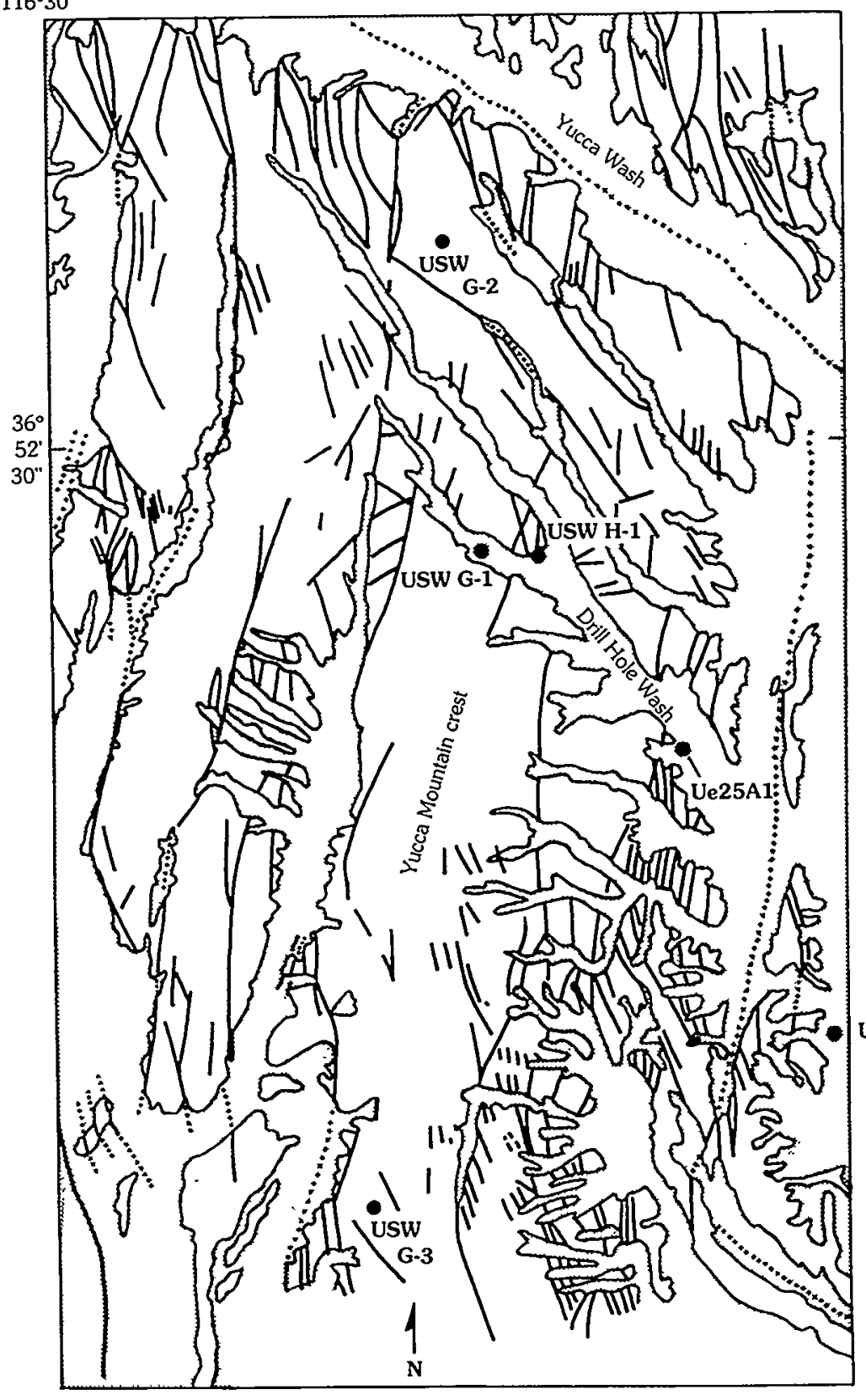

\section{EXPLANATION}

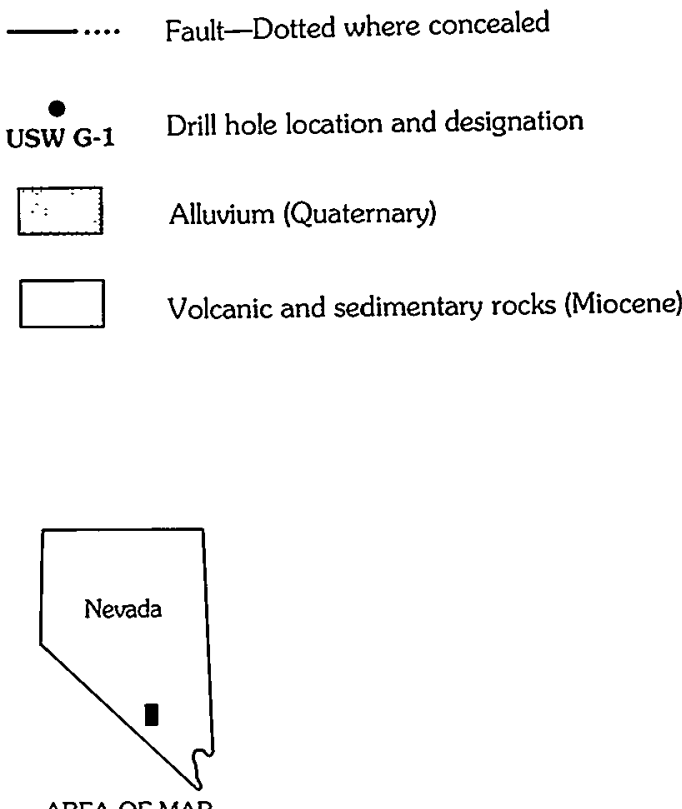

AREA OF MAP

Ue25P1

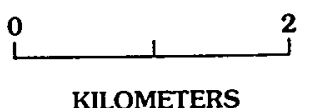

KILOMETERS

Figure 6.1. Generalized geologic map of Yucca Mountain, Nev., showing locations and names of drill holes discussed in text. Geology generalized from Scott and Bonk (1984). 
must be made for absolute depth and changes in overburden due to rapidly varying surface topography, thus adding uncertainty to the estimate of $S_{v}$.

If the topography is irregular, small-wavelength variations should be averaged out before calculation of $S_{v}$ at depth. Such corrections are most important for USW G-3. For instance, the elevation of the surface at USW G-3 is $1,480 \mathrm{~m}$; however, the average surface elevation within a circle of $700 \mathrm{~m}$ radius centered on the top of the hole is approximately $1,390 \mathrm{~m}$. If the circle is centered on the surface projection of the position of our lowest test, the average surface elevation is $1,370 \mathrm{~m}$. The $S_{v}$ values listed for the USW G-3 tests (table 6.1) include a correction obtained using a 700-m radius because that is the average depth of the USW G-3 tests below the surface. Maximum uncertainty limits on these values can be estimated using the uncorrected value of $S_{\nu}$ as an upper bound, and the average topography in the absence of the excess height of the ridge as a lower bound; this gives an uncertainty of $\pm 2.0-2.5 \mathrm{MPa}$ for the $S_{v}$ values in USW G-3. An estimate for the $S_{v}$ correction can also be derived analytically if the surface topography can be approximated as a smooth function, and density and elastic constants are assumed uniform (see Swolfs and Savage, 1985).

Stress values obtained at Yucca Mountain are summarized in table 6.1 and figure 6.2. The corresponding pressure-time data have been discussed elsewhere (Healy and others, 1984; Stock and others, 1984, 1986). We reproduce here some sample test curves (fig. 6.3) to illustrate the details of interpretation and some unusual conditions encountered in the Yucca Mountain holes.

For the deeper successful tests in these holes, the breakdown pressures were clear and distinct, and the ISIPs occurred at pressures higher than the surface hydrostat (pressure of a column of water filling the hole to the surface). The pressure-time curves show an inflection when the pressure equals the surface hydrostat, at a level below the $S_{h}$ value obtained from ISIP and steprate injection tests on the final cycles. Such behavior was seen during the tests at $1,038,1,218$, and $1,288 \mathrm{~m}$ in USW G-1; 1,026 and $1,209 \mathrm{~m}$ in USW G-2; and 1,573 $\mathrm{m}$ in Ue25P1 (see fig. 6.3A).

On some other tests, good breakdown pressures were observed, with ISIP values less than the surface hydrostat. Such behavior was seen during the three successful tests in USW G-3, at $1,074,1,338$, and $1,356 \mathrm{~m}$; and in USW G-1, at 646,792 , and $945 \mathrm{~m}$ (see fig. 6.3B).

Several tests showed breakdown pressures that were equal to the fracture reopening pressure on later cycles. This suggested that the effective tensile strength of the formation was zero, probably because a preexisting fracture was present in the interval and was reopened during the test. As this occurred in regions of the hole where preexisting fractures are likely (above the water table in USW G-2 and in bedded carbonate units at 1,564 and $1,693 \mathrm{~m}$ in Ue25P1), we prefer this explanation for the repeatable character of these test curves (see fig. 6.3C). Preexisting fractures may not be oriented perpendicularly to the $S_{h}$ direction; thus, the estimated normal stress across them can only be used as an upper bound on the value of the minimum stress (in this case, $\left.S_{h}\right)$ at depth.

The types of pressure-time curves discussed above encompass those from which values of $S_{h}$ or $S_{H}$ were obtained. A fourth type of curve showed a large pressure drop once the interval was open to the pressure in the tubing string. This behavior may be due to an unidentified equip-

Table 6.1. Summary of hydraulic fracturing stress measurements at Yucca Mountain

[Pore pressures are based on the water levels recorded before testing: USW G-1, $575 \mathrm{~m}$; USW G-2, $526 \mathrm{~m}$; USW G-3, $752 \mathrm{~m}$; Ue25P1, $385 \mathrm{~m}$ ]

\begin{tabular}{|c|c|c|c|c|c|c|c|}
\hline $\begin{array}{l}\text { Drill } \\
\text { hole }\end{array}$ & $\begin{array}{l}\text { Logged } \\
\text { depth } \\
(m)\end{array}$ & $\begin{array}{l}\text { True } \\
\text { depth } \\
\text { (m) }\end{array}$ & $\begin{array}{c}S_{v} \\
(\mathrm{MPa})\end{array}$ & $\begin{array}{c}S_{h} \\
(\mathrm{MPa})\end{array}$ & $\begin{array}{c}S_{H} \\
\text { (MPa) }\end{array}$ & $\begin{array}{c}\text { Pore } \\
\text { pressure } \\
\text { (MPa) }\end{array}$ & $\phi$ \\
\hline USW $\mathrm{G}-2-\cdots$ & 295 & 295 & 6.1 & $<5.1 \pm 0.1$ & - & 0 & -- \\
\hline USW G-2--- - & 418 & 418 & 8.4 & $<5.4 \pm 0.1$ & -- & 0 & - \\
\hline USW G-2 - & 432 & 432 & 8.7 & $<5.5 \pm 0.1$ & - & 0 & - \\
\hline USW G-1-- & 646 & 646 & 12.9 & $-4.2 \pm 0.2$ & -- & 0.7 & $-\infty$ \\
\hline USW G-1 & 945 & 945 & 19.2 & $9.0 \pm 0.2$ & $\ldots$ & 3.6 & -- \\
\hline USW G-3 & 1,074 & $1_{1,068}$ & $20.6 \pm 2.0$ & $6.8 \pm 0.2$ & $10.7 \pm 1.0$ & 3.1 & -0.28 \\
\hline USW G-2---- & 1,026 & 1,026 & 20.8 & $11.1 \pm 0.2$ & $16.8 \pm 0.4$ & 4.9 & .59 \\
\hline USW G-1--. & 1,038 & 1,038 & 21.4 & $10.6 \pm 0.2$ & -- & 4.5 & - \\
\hline USW G-1---n & 1,218 & 1,218 & 25.5 & $12.1 \pm 0.2$ & -- & 6.3 & -- \\
\hline USW G-2- & 1,209 & 1,209 & $25 \cdot 5$ & $12.0 \pm 0.2$ & $17 \cdot 3 \pm 0.4$ & 6.7 & .39 \\
\hline USW G-3 - & 1,338 & 11,321 & $25.8 \pm 2.5$ & $11.5 \pm 0.2$ & $17.5 \pm 0.9$ & 5.6 & -.45 \\
\hline USW G-3-n. & 1,356 & 1,338 & $26.3 \pm 2.5$ & $11.4 \pm 0.2$ & $18.1 \pm 0.8$ & 5.7 & -.45 \\
\hline Ue25P1 & 1,564 & 1,564 & 35.3 & $<33.7 \pm 0.2$ & -- & 11.5 & - \\
\hline Ue25P1- & 1,573 & 1,573 & 35.6 & $20.7 \pm 0.2$ & $31.0 \pm 1.1$ & 11.6 & .69 \\
\hline Ue25P1-- & 1,693 & 1,693 & 38.8 & $\leq 36.5 \pm 1.0$ & - & 12.8 & -- \\
\hline
\end{tabular}


ment problem or to some unusual property of the rock in the test interval. Such behavior was common in tests in the tuffs and lavas of the Calico Hills unit in USW G-2.

\section{STRESS DIRECTIONS}

The orientations of the principal stresses can be found from observation of directional features in drill holes, including hydraulic fractures (both test-induced and drillinginduced) and directional wellbore spalling, or breakouts. These and other borehole features are visible on acoustic televiewer logs of the drill holes. Operational principles of the televiewer have been described by Zemanek and others (1969), and details of interpretation of borehole features are described in our previous reports.

Preexisting fractures intersected by the borehole can be seen as dark, sinusoidal traces in the televiewer log. Their amplitude and phase can be measured to determine the strike and dip of the fracture. Such fractures are present in all four holes. Their strike directions tend to vary from north to northeast, they dip steeply, and they tend to become less steep, with more scattered orientations, at depth. Their orientations provide no direct indication of stress direction, but they do show that the degree of fracture anisotropy, which may be pronounced at shallow levels, decreases or disappears at depth.

\section{HORIZONTAL STRESS, IN MEGAPASCALS}

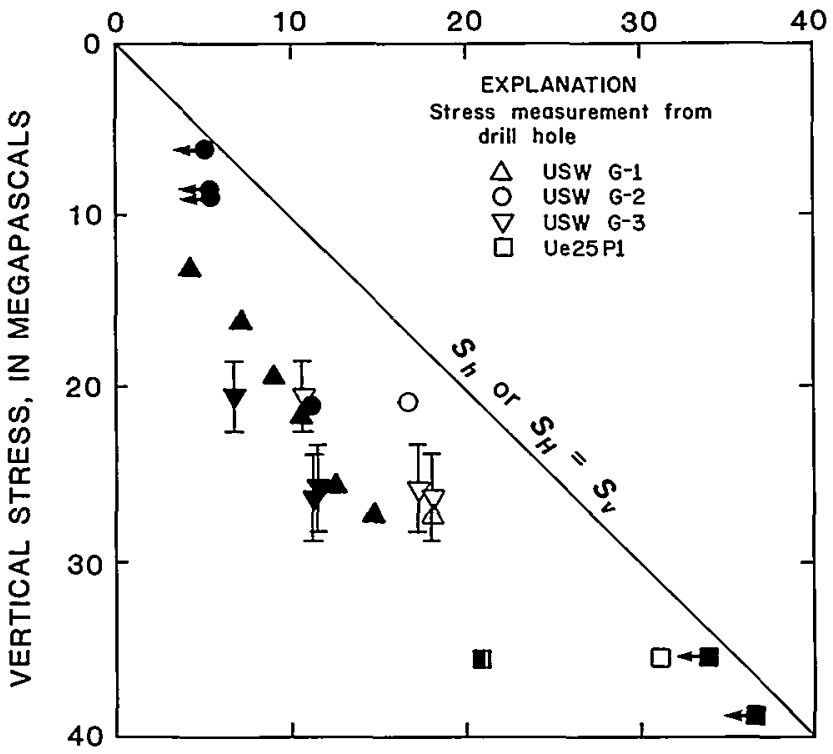

Figure 6.2. Values of least horizontal principal stress $S_{h}$ (solid symbols) and greatest horizontal principal stress $S_{H}$ (open symbols) plotted as a function of vertical stress, $S_{v}$. Horizontal arrows indicate that values are upper bounds. Vertical bars indicate range of uncertainty associated with $S_{v}$ values in drill hole USW G-3, due to topographic effects.
In addition to preexisting fractures, very steep to vertical fractures follow the hole for many tens of meters in the televiewer logs of USW G-1 (520-760 m depth), USW G-2 (526-678 $\mathrm{m}$ depth), and USW G-3 (at intervals from 882 to $1,018 \mathrm{~m}$ ). In some cases these do not appear to be throughgoing fractures, as they have no observed trace on the opposite azimuth in the televiewer log. They vary in aspect from en echelon and jagged, connected to or interrupted by throughgoing fractures, to straight and continuous. These fractures have an average strike of $\mathrm{N} .25^{\circ} \mathrm{E}$. in USW G-3, N. $15^{\circ}$ E.-N. $35^{\circ}$ E. in USW G-1, and N. $25^{\circ}$ E.-N. $30^{\circ} \mathrm{E}$. in USW G-2. Most notably, these fractures cannot be identified on corresponding sections of the drill core, suggesting that they were formed after coring but prior to the collection of the televiewer data. We believe that these are hydraulic fractures induced by drilling. The low values of $S_{h}$ measured elsewhere in the holes, if present at the depths of these features, could have been exceeded by raising the water level to the surface by filling the hole with fluid. Such fractures could accept fluid when the water level was still below the surface of the hole, providing a reasonable
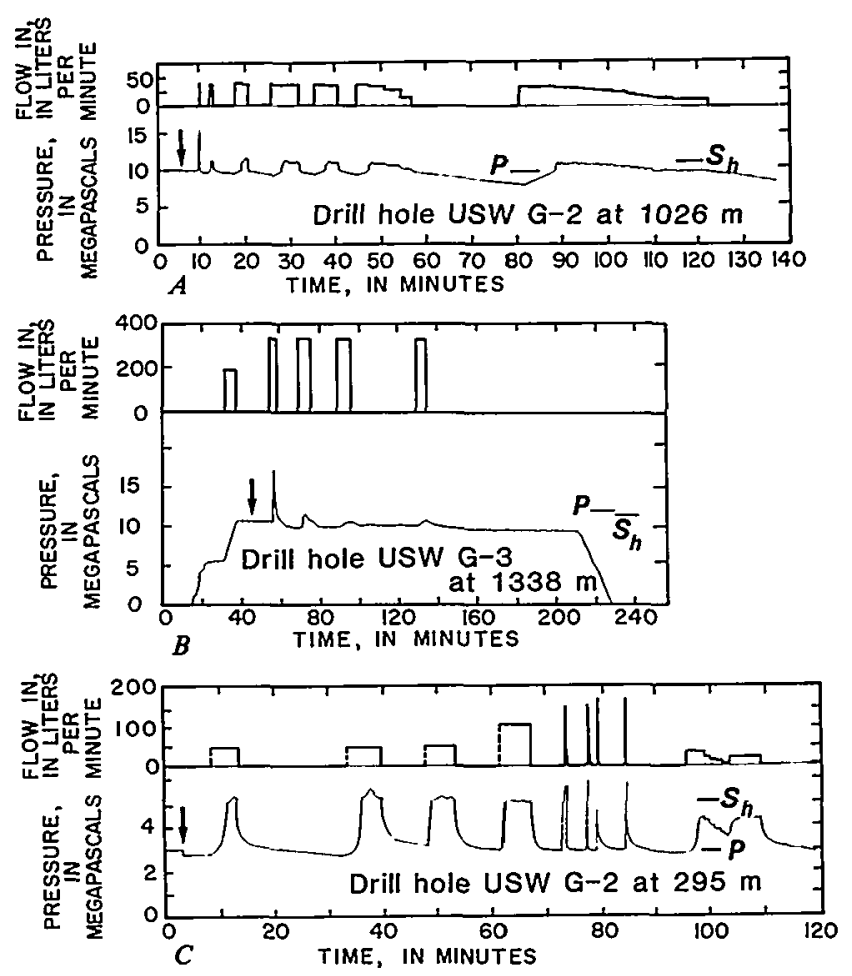

Figure 6.3. Pressure-time curves from hydraulic fracturing tests at Yucca Mountain. Least horizontal principal stress (instantaneous shut-in pressure), $S_{h}$; surface hydrostatic pressure, $P . A$, Clear breakdown with $S_{h}$ greater than $P$. B , Clear breakdown with $S_{h}$ less than $P$. $C$, Breakdown pressure equal to fracture reopening pressure on later cycles, indicating that a preexisting fracture is being reopened. Arrows show time at which test interval was opened to pressure in tubing string. 
explanation for the huge volumes of drilling fluid that were lost in the three holes and the continuous loss of circulation during drilling. In Ue25P1, drilling-induced hydraulic fractures are not observed, and circulation was maintained during drilling.

If these are indeed hydraulic fractures, their strike implies an $S_{h}$ direction of N. $60^{\circ}$ W.-N. $65^{\circ}$ W. in these three holes. This direction is also suggested by the orientations of breakouts in USW G-1, USW G-2, and Ue25P1. These breakouts are spalled portions of the borehole wall which are visible as dark bands of the televiewer log at azimuths $180^{\circ}$ apart. When the returning televiewer signal is plotted as traveltime against azimuth, to yield a cross section of the shape of the hole, these dark patches are seen to correspond to sections of the hole with unusually large radii.

Breakouts in many regions provide consistent, regional information on the horizontal principal stress directions because they form at the azimuth of the maximum compressive stress around the borehole, the $S_{H}$ azimuth (see Bell and Gough, 1983). The average N. $60^{\circ} \mathrm{W}$. to N. $65^{\circ} \mathrm{W}$. orientation of breakouts in USW G-2 (between 1,053 and $1,219 \mathrm{~m}$ ) and $\mathrm{N} .60^{\circ} \mathrm{W}$. azimuth of breakouts in Ue25P1 (between 1,524 and 1,676 m) suggest an $S_{h}$ orientation of $\mathrm{N} .60^{\circ} \mathrm{W}$., consistent with the orientation inferred from the drilling-induced hydraulic fractures. Breakouts from 1,113 to $1,202 \mathrm{~m}$ in USW G-1 had a S. $80^{\circ} \mathrm{W}$. azimuth, indicating an $S_{h}$ direction $40^{\circ}$ off from all other directional data. These occur in an inclined portion of the hole ( $9^{\circ}$ from vertical); however, modeling shows that this breakout azimuth could not have resulted from the observed hole deviation and the measured Yucca Mountain stress field with $S_{H}$ at N. $25^{\circ}$ E., $S_{h}$ at N. $65^{\circ}$ W., $S_{v}$ vertical, and $\phi$, or $\left(S_{H}-S_{h}\right) /\left(S_{v}-S_{h}\right)$, between 0.25 and 0.7 (Stock and others, 1985). Therefore, a local perturbation of the stress field seems likely.

\section{AGREEMENT WITH REGIONAL DATA}

The observed stress directions are in good agreement with directions derived from regional data showing northwest to west-northwest orientation of $S_{h}$ (Carr, 1974; Zoback and Zoback, 1980; Stock and others, 1985). The N. $60^{\circ} \mathrm{W}$. to N. $65^{\circ} \mathrm{W} . S_{h}$ direction that we find at Yucca Mountain is slightly more westerly than the N. $45^{\circ} \mathrm{W}$. to N. $55^{\circ} \mathrm{W}$. $S_{h}$ orientations reported from hydraulic fracturing in Rainier Mesa (Haimson and others, 1974; Warren and Smith, 1985) and the N. $45^{\circ} \mathrm{W}$. to N. $60^{\circ} \mathrm{W}$. $S_{h}$ orientation derived from breakouts in drill holes in Yucca Flat and Pahute Mesa (Carr, 1974; Springer and Thorpe, 1981). However, they are within the scatter of this regional data and are considered to be consistent with it.

The observed stress magnitudes indicate a normal faulting stress regime, with $S_{h}<S_{H}<S_{v}$. This is consistent with regional earthquake and geologic data, which show a combination of normal and strike-slip faulting, implying that $S_{h}<S_{H}<S_{v}$ (see Stock and others, 1985). The ratio $\phi$, equal to $\left(S_{H}-S_{h}\right) /\left(S_{v}-S_{h}\right)$ in a normal faulting regime, indicates how close the stress magnitudes lie to a "pure normal faulting regime" $(\phi=0)$ or a "combined normal and strike-slip faulting regime" $(\phi=1)$. The $\phi$ values obtained from these holes are scattered, ranging from 0.69 (at $1,573 \mathrm{~m}$ in Ue25P1) to $0.25(1,288 \mathrm{~m}$ in USW G-1), but the highest $\phi$ values are found at the deepest structural levels. If the Yucca Mountain stress field tends toward higher values with structural depth, extrapolation to deeper levels should be based on higher $\phi$ values than the average of our test measurements. These may also be more representative of the regional stress field.

\section{TOPOGRAPHIC EFFECTS ON THE HORIZONTAL STRESS}

Topographic corrections to $S_{v}$ are important in USW G-3, as previously noted. Analytical solutions (Savage and Swolfs, 1986) and approximations to the stress field in regions of moderate relief (McTigue and Mei, 1981) indicate that the topographic effect on the horizontal stresses is generally negligible at depths greater than one wavelength of the topography (see Jaeger and Cook, 1979, p. 373). The topographic variation at USW G-1, USW G-2, and Ue25P1 has a wavelength of $500 \mathrm{~m}$; its amplitude is small, and the surface elevations of the holes are quite close to the average elevation over distances equal to the depths of our tests. Therefore, the topographic effects on $S_{h}$ and $S_{H}$ should be minimal. Although USW G-3 is in an area of steeper topography, modeling by Swolfs and Savage (1985) shows that the topographic effect on the horizontal stresses will be larger than the uncertainty in the hydrofrac tests only within a few hundred meters of the surface. Since our tests here were at much deeper levels, we conclude that topographic influence on the measured $S_{h}$ values is too small to be detected.

Additional evidence for this conclusion comes from the $S_{h}$ orientations in these holes. They all show a consistent $S_{h}$ azimuth of N. $60^{\circ} \mathrm{W}$. to N. $65^{\circ} \mathrm{W}$., which is maintained in the presence of both a north-south topographic grain (near USW G-3 and Ue25P1) and a northwest-southeast topographic grain (near USW G-1 and USW G-2). Since a topographically controlled stress field should have $S_{h}$ directions perpendicular to the strike of the topography, it appears that the Yucca Mountain stress field, at the depths studied (below the water table), is not strongly influenced by topography. The continuity of stress directions from the volcanics into the underlying carbonate rocks argues against a strong component of residual or cooling stresses influencing the stress field in the volcanic rocks, suggesting that the stress field is primarily the result of current tectonic processes. 


\section{TECTONIC IMPLICATIONS}

The most important characteristic of these stress measurements is the consistently low value of $S_{h}$ relative to $S_{v}$. As discussed in previous reports (Healy and others, 1984; Stock and others, 1984, 1985), the measured $S_{h}$ values fall close to the limits at which frictional sliding, in a normalfaulting sense, might be expected to occur on optimally oriented preexisting faults. These low $S_{h}$ values have an even more dramatic consequence: the long drilling-induced hydraulic fractures present in the upper parts of the three USW G holes. Such fractures could propagate even in the absence of a drill hole to concentrate the stresses, if the pore pressure in small cracks locally exceeded $S_{h}$. (This situation has been observed in other active extensional areas; see Zoback and Healy, 1984.)

Our data suggest that in the presence of such a stress field, if the pore pressure were to increase and exceeded $S_{h}$ (due to a natural rise of the water table or to human activities, such as fluid injection), cracks could open perpendicular to $S_{h}$. These open cracks could then act as pathways for fluid flow and dissipate the excess pore pressure, until it dropped back to the $S_{h}$ magnitude and the cracks could close. This implies that there may be a delicate balance between the hydrology and the stress field at Yucca Mountain, with the magnitude of $S_{h}$ acting as a limit to possible increases in water level. Because $S_{h}$ increases faster with depth than does the hydrostatic pressure, this effect becomes less important with depth, and is unlikely to be of concern where $S_{h}$ exceeds the surface hydrostat. However, within the first kilometer of the surface, this effect is likely to be a major control on the hydrology of Yucca Mountain, and influence the tectonic response to human activities which produce major changes in local pore pressure.

\section{CONCLUSIONS}

In hydraulic fracturing stress measurements in four holes at Yucca Mountain, both the least horizontal principal stress $S_{h}$ and the greatest horizontal principal stress $S_{H}$ are less than the vertical stress $S_{v}$, indicating a normal-faulting stress regime. Plots of $S_{h}$ and $S_{H}$ as a function of $S_{v}$ demonstrate that all of the $S_{h}$ values are reasonably linear with respect to $S_{v}$. The few $S_{H}$ values obtained from the USW holes are substantially less than $S_{v}$, whereas the one $S_{H}$ value from Ue25P1 is closer to, although less than, $S_{v}$. The $S_{h}$ direction is N. $60^{\circ} \mathrm{W}$. to N. $65^{\circ} \mathrm{W}$., in good agreement with regional stress indicators.

Upward extrapolation of these results should be done with caution, as topographic effects are more important near the surface. In order to obtain an accurate picture of the stress field in the unsaturated zone, in the area of the proposed repository, a numerical model incorporating these results and including actual topography, observed distribution and physical constants of volcanic units, and reasonable bound- ary conditions should be developed. Such a model should be checked for consistency with future stress measurements (hydraulic fracturing and overcoring) made closer to the position of the proposed repository, in both the saturated and unsaturated zones.

\section{REFERENCES CITED}

Bell, J.S., and Gough, D.I., 1983, The use of borehole breakouts in the study of crustal stress, in Zoback, M.D., and Haimson, B.C., eds., Hydraulic fracturing stress measurements: Washington, D.C., National Academy Press, p. 201-209.

Bredehoeft, J.D., Wolff, R.G., Keys, W.S., and Shuter, E., 1976, Hydraulic fracturing to determine the regional in-situ stress field, Piceance Basin, Colorado: Geological Society of America Bulletin, v. 87 , p. $250-258$.

Carr, W.J., 1974, Summary of tectonic and structural evidence for stress orientation at the Nevada Test Site: U.S. Geological Survey Open-File Report 74-176, 53 p.

Haimson, B.C., Lacomb, J., Jones, A.H., and Green, S.J., 1974, Deep stress measurements in tuff at the Nevada Test Site, in Advances in rock mechanics: Washington, D.C., National Academy of Sciences, p. 557-561.

Healy, J.H., Hickman, S.H., Zoback, M.D., and Ellis, W.L., 1984, Report on televiewer log and stress measurements in core hole USW G-1, Nevada Test Site: U.S. Geological Survey Open-File Report 84-15, 47 p.

Hickman, S.H., and Zoback, M.D., 1983, The interpretation of hydraulic fracturing pressure-time data for in-situ stress determination, in Zoback, M.D., and Haimson, B.C., eds., Hydraulic fracturing stress measurements: Washington, D.C., National Academy Press, p. 44-54.

Hubbert, M.K., and Willis, D.G., 1957, Mechanics of hydraulic fracturing: Journal of Petroleum Technology, v. 9, p. 153-168.

Jaeger, J.C., and Cook, N.G.W., 1979, Fundamentals of rock mechanics, 3d ed.: London, Chapman and Hall, 593 p.

McTigue, D.F., and Mei, C.C., 1981, Gravity-induced stresses near topography of small slope: Journal of Geophysical Research, v. 86, p. 9268-9278.

Savage, W.Z., and Swolfs, H.S., 1986, Tectonic and gravitational stress in long symmetric ridges and valleys: Journal of Geophysical Research, v. 91, p. 3677-3685.

Scott, R.B., and Bonk, Jerry, 1984, Preliminary geologic map of Yucca Mountain with geologic sections, Nye County, Nevada: U.S. Geological Survey Open-File Report 84-494, 9 p., scale $1: 12,000$.

Springer, J.E., and Thorpe, R.K., 1981, Borehole elongation versus in situ stress orientation: Livermore, Calif., Lawrence Livermore Laboratory Report UCRL-87018, 15 p.

Stock, J.M., Healy, J.H., and Hickman, S.H., 1984, Report on televiewer $\log$ and stress measurements in core hole USW G-2, Nevada Test Site: U.S. Geological Survey Open-File Report 84-172, $31 \mathrm{p}$.

Stock, J.M., Healy, J.H., Hickman, S.H., and Zoback, M.D., 1985, Hydraulic fracturing stress measurements at Yucca Mountain, Nevada, and relationship to the regional stress field: Journal of Geophysical Research, v. 90, p. 8691-8708.

Stock, J.M., Healy, J.H., Svitek, J., and Mastin, L., 1986, Report on televiewer log and stress measurements in holes USW G-3 
and Ue-25p\#1, Yucca Mountain, Nevada Test Site: U.S. Geological Survey Open-File Report 86-369, 91 p.

Swolfs, H.S., and Savage, W.Z., 1985, Topography, stresses, and stability at Yucca Mountain, Nevada: paper presented at 40th U.S. Rock Mechanics Symposium, Rapid City, S.D., June 1985.

Warren, W.E., and Smith, C.W., 1985, In situ stress estimates from hydraulic fracturing and direct observation of crack orientation: Journal of Geophysical Research, v. 90, p. 6829-6839.

Zemanek, J.R., Caldwell, L., Glenn, E.E., Holcomb, S.V.,
Norton, L.J., and Straus, A.J.D., 1969, The borehole televiewer: A new logging concept for fracture location and other types of borehole inspection: Journal of Petroleum Technology, v. 21, p. 702-774.

Zoback, M.D., and Healy, J.H., 1984, Friction, faulting, and insitu stress: Annales Geophysicae, v. 2, p. 689-698.

Zoback, M.L., and Zoback, M.D., 1980, State of stress in the conterminous United States: Journal of Geophysical Research, v. 85 , p. $6113-6156$. 


\title{
7. An Evaluation of the Topographic Modification of Stresses at Yucca Mountain, Nevada
}

\author{
By Henri S. Swolfs, William Z. Savage, and William L. Ellis
}

\section{CONTENTS}

\author{
Abstract 95 \\ Introduction 95 \\ Observations 96 \\ Analysis 97 \\ Topography 97 \\ Fracture anisotropy 100 \\ Conclusions 101 \\ References cited 101
}

\begin{abstract}
Stress components measured by the hydraulic-fracturing technique at Yucca Mountain, Nye County, Nevada, are in good agreement with a plane-strain analytical solution for the gravitational state of stress beneath a long, symmetrical ridge. Both the analytical model and the field observations indicate that the horizontal stress components beneath the base of the ridge are reduced in magnitude relative to horizontal stress components beneath the flanks of the ridge, or at locations where the ridge topography is less pronounced. We propose that this stress reduction is due to gravitational spreading at depth beneath the ridge and that this localized effect on the stress field penetrates to depths several times the height of the ridge. A well-developed set of faults and fractures, subparallel to the north-south-trending ridge, imparts a vertical transverse isotropy to the rock and, as a consequence of gravitational loading, induces unequal horizontal stresses in directions parallel and perpendicular to the anisotropy.
\end{abstract}

\section{INTRODUCTION}

Yucca Mountain, located on the west boundary of the Nevada Test Site (fig. 7.1), is a north-south-trending ridge of moderate relief that projects southward from the higher terrain near Timber Mountain into the lower, broad plains of Crater Flat, the Amargosa Desert, and Jackass Flats. Regional gravity and seismic-refraction surveys (Mooney and others, 1982; Snyder and Carr, 1984), as well as extensive drilling in the area, reveal that Yucca Mountain and Crater Flat are underlain by a thick (3-4 km) section of ash-flow tuffs and associated extrusive rocks that fill a steep-sided north-south-trending depression in the pre-volcanic rocks. The east edge of this depression rises to within $1.5 \mathrm{~km}$ of the surface just east of Yucca Mountain, where Ordovician and Silurian carbonate rocks have been penetrated (Carr and others, 1986).

Yucca Mountain is cut by major north-south to northeast-southwest-striking and generally westward-dipping normal faults (fig. 7.2), forming blocks of Miocene ash-flow tuffs tilted gently eastward (Scott and others, 1983; Scott and Castellanos, 1984; Scott and Bonk, 1984). In general, the density of these faults decreases toward the north, where northwest-southeast-striking strike-slip faults with apparent right-lateral offset become common (Scott and others, 1983). The rock types in these blocks include densely welded devitrified and vitric ash-flow tuff, nonwelded victric ashflow tuff, vitric bedded tuff, nonwelded zeolitic and argillaceous ash-flow tuff, and zeolitic and argillaceous bedded tuff.

As revealed by structural mapping of the surface of Yucca Mountain and analyses of oriented cores (Scott and others, 1983), fractures and minor faults are abundant and pervasively distributed throughout Yucca Mountain. The dominant fractures have steep to near-vertical westward dips and nearly constant northward to northwestward strikes. The frequency of these fractures is several times greater in the welded tuffs than in the nonwelded tuffs. The orientation and attitude of these fractures impart a mechanical anisotropy to the rocks; in fact, Scott and others (1983) attributed the observed deviation from vertical of several deep drill holes, as well as the directions of deviation, to this anisotropy.

Because the static water table at Yucca Mountain is 500 to $800 \mathrm{~m}$ below the surface, the unsaturated zone above the water table is being considered as a possible location for a nuclear waste repository (Winograd, 1981; Roseboom, 1983). The study and characterization of the constraints imposed on the design and construction of the repository by the geological environment include the investigation of the regional stress. As reported in chapter 6 , measurements of stress using the hydraulic fracturing technique (Haimson and Fairhurst, 1967) have been made in several drill holes by the U.S. Geological Survey (Healy and others, 1984; Stock and others, 1984; J.M. Stock, written commun., 1984). The majority of these measurements were made in the saturated zone below the water table to a depth of $1.4 \mathrm{~km}$. Extrapolation of the results of stress measurement upward into the unsaturated zone is unwarranted without some theoretical guidance.

The aim of this report is to describe two aspects that may exert some influence on the local state of stress in Yucca Mountain. First, we consider the stresses induced at

Topographic Modification of Stresses 95 
repository depths by topography alone using solutions of Savage and others (1985), and second we consider the separate effect of fracture anisotropy on the horizontal-stress distribution following the procedures outlined by Amadei and others (1987). Both approaches deal with the gravitational component of the stress field only. Implicit in the analyses is the assumption of lateral restraint (Jaeger and Cook, 1979, p. 371). We justify these boundary conditions as follows: there will be a finite distance from the ridge beyond which displacements due to the ridge become vanishingly small. Because Yucca Mountain, and especially its southern part, is bordered by two broad flats, we are satisfied that these boundary conditions apply at distances of a few kilometers from the ridge.

\section{OBSERVATIONS}

To date, 11 hydraulic-fracturing tests have been conducted to estimate the stresses in the saturated zone of Yucca Mountain (Healy and others, 1984; Stock and others, 1984; J.M. Stock, written commun., 1984) at depths from 646 to

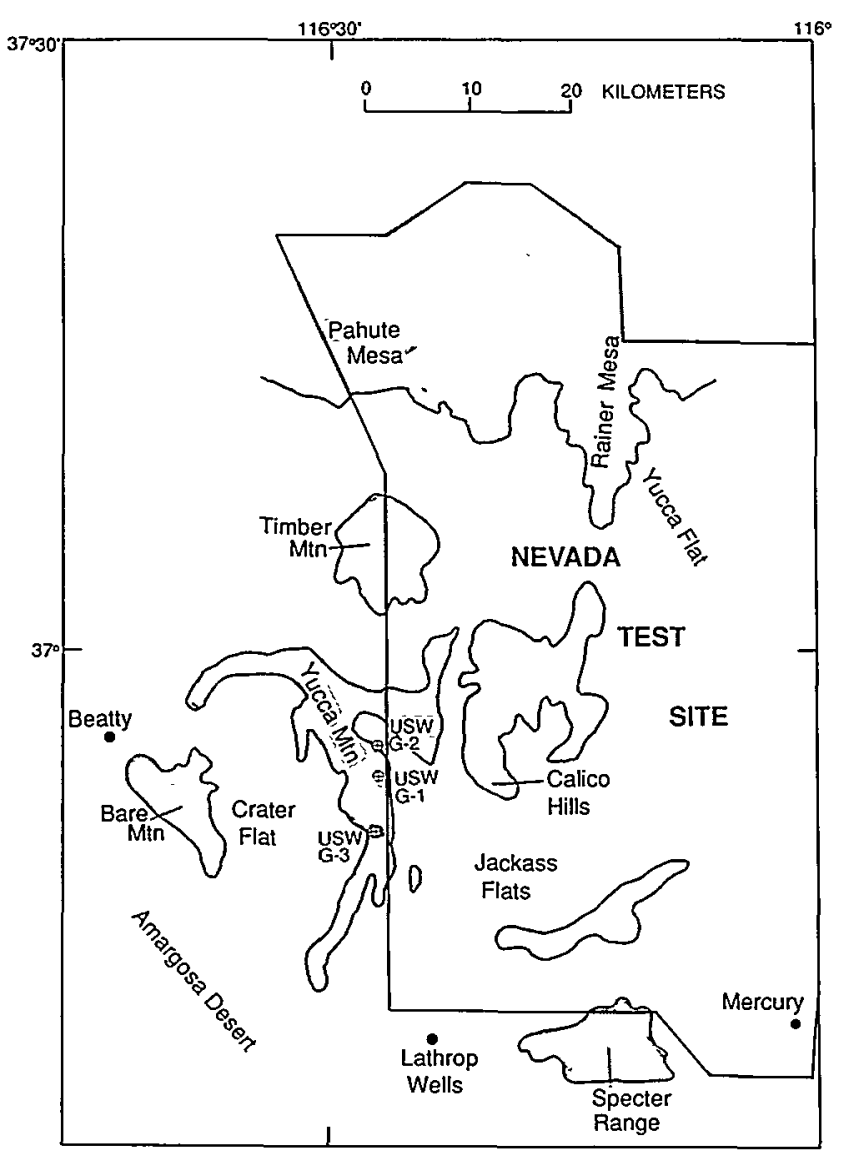

Figure 7.1. Location of Yucca Mountain and drill holes USW G-1, USW G-2, and USW G-3. Shaded areas of positive relief expose Miocene and Pliocene ash-flow tuffs; Paleozoic sedimentary rocks underlie Bare Mountain and Specter Range.
$1,338 \mathrm{~m}$ (fig. 7.3). Six of these tests were done in drill hole USW G-1 and two in USW G-2, located north of the proposed repository block and east of the ridge crest. The three remaining tests were done in drill hole USW G-3, located in the southernmost part of the repository block on the crest of the ridge (fig. 7.1). The results of these tests show that the least horizontal stress $\left(S_{h}\right)$ increases from 4.2 to 14.8 $\mathrm{MPa}$ in the test intervals from 646 to $1,288 \mathrm{~m}$ in holes USW G-1 and USW G-2, and from 6.8 to $11.5 \mathrm{MPa}$ in the test intervals from 1,068 to $1,338 \mathrm{~m}$ in hole USW G-3 (fig 7.3). The depths in hole USW G-3 have been corrected for borehole deviation (J.M. Stock, oral commun., 1985). Due to the overburden weight, the vertical stress $\left(S_{v}\right)$ increases at an average rate of $20.6 \mathrm{MPa} / \mathrm{km}$. The few calculations of the greatest horizontal stress $\left(S_{H}\right)$ indicate that it increases from 16.8 to $17.9 \mathrm{MPa}$ in holes USW G-1 and USW G-2, and from 10.6 to $18.1 \mathrm{MPa}$ in hole USW G-3 (see table 6.1 in chapter 6). These results indicate that the stresses at Yucca Mountain are such that $S_{H} / S_{v} \cong 3 / 4$ and $S_{h} / S_{v} \cong 1 / 2$.

The measured stresses at shallow depths beneath Yucca Mountain are consistent with normal faulting or an extensional stress regime where $S_{\nu}>S_{H}>S_{h}$. This also agrees with the fault orientations shown in figure 7.2. However, as shown in figure 7.3, the stresses obtained in hole USW G-3 are smaller than those obtained at equal depths in either hole USW G-1 or USW G-2. The static water levels are found at depths of $575 \mathrm{~m}$ in hole USW G-1, $526 \mathrm{~m}$ in hole USW G-2, and $752 \mathrm{~m}$ in hole USW G-3 (Scott and others, 1983).

Horizontal-stress orientations have been inferred from drilling-induced hydraulic fractures and sidewall spalling (breakouts) observed along sections of the drill holes by means of televiewer surveys (Healy and others, 1984; Stock and others, 1984; J.M. Stock, written commun., 1984). Hydraulic fractures are likely to be propagated when the bottom-hole pressures of the drilling fluid exceed the value of $S_{h}$, the least horizontal stress. At Yucca Mountain, this criterion is readily satisfied by filling the holes to the surface with drilling fluid (Ellis and Swolfs, 1983). The drillinginduced fractures are parallel to the drill holes for long near-vertical distances and strike north-south to northeastsouthwest. In near-vertical holes, breakouts are zones of limited failure that are oriented in directions normal to the greatest horizontal stress or at right angles to the hydraulicfracture planes (Jaeger and Cook, 1979, p. 238). The azimuths of the observed breakouts in holes USW G-1 and USW G-2 are west to west-northwest; no breakouts were recognized in hole USW G-3. For the purposes of this paper, we take the orientation of the least horizontal stress $\left(S_{h}\right)$ to be normal to the strike of Yucca crest (fig. 7.2), and the orientation of the greatest horizontal stress $\left(S_{H}\right)$ to be parallel to the strike of Yucca crest and the vertical fractureanisotropy. Even though this introduces a discrepancy of about $30^{\circ}$ in stress orientation, it is not likely to invalidate our general conclusions with regard to a topographic effect on stress beneath Yucca Mountain. The vertical stress $\left(S_{v}\right)$ is assumed equal to the weight of the overburden. 


\section{ANALYSIS}

\section{Topography}

The least horizontal stresses measured beneath the base of Yucca Mountain in hole USW G-3 are smaller than those measured at comparable depths under the eastern flank of the ridge in holes USW G-1 and USW G-2 (fig. 7.3). In order to explain this observation, we use the results of Savage and others (1985), who derived an exact solution for topographically induced stresses by the Kolosov-Muskhelishvili method of complex potentials for plane elasticity. A conformal mapping function transforms an isolated symmetric ridge (fig. 7.4) into a half-plane, in which expressions are obtained for the gravity-induced stresses in the symmetric ridge. Stresses given by the solution satisfy all conditions of the problem; that is, shear stresses vanish on the ridge surface and on the axial plane of the ridge, stresses normal to the ridge surface vanish, and at great depth and distance from the ridge, all stresses are compressive and approach the state of stress given by the assumption of lateral restraint (Jaeger and Cook, 1979, p. 371).

In a contour diagram of the dimensionless least horizontal stress $S_{h} / \rho g b$ for a symmetric ridge, where $\rho g b$ is the characteristic stress at the base of the ridge and $b$ is the ridge height (fig. 7.5), the ridge shape conforms closely to the topographic cross section in the vicinity of hole USW G-3 (fig. 7.2). It is clear that the stress contours do not follow the ridge shape, but concentrate along the flanks, and at depth along the axial plane of the ridge, the stress contours are deepened relative to those under the flanks. This reduction of horizontal stress under the ridge to depths several times the ridge height is attributed to gravitational spreading of the ridge.
East-west cross sections through Yucca Mountain incorporating holes USW G-1, USW G-2, and USW G-3 are approximated by the conformal mapping function. For example, near USW G-3 the actual cross section of the ridge is modeled as $250 \mathrm{~m}$ high and $750 \mathrm{~m}$ wide between the inflection points on the flanks (fig. 7.2). Assuming the ridge materials to be isotropic, homogeneous, and elastic, the topographically induced stresses are calculated for a measured Poisson's ratio of $\nu=0.32$ (Ellis and Swolfs, 1983, fig. 3), and an average density of $\rho=2.14 \mathrm{~g} / \mathrm{cm}^{3}$. The calculated variations of the least horizontal and vertical stresses $\left(S_{h}\right.$ and $\left.S_{v}\right)$ with depth as solid curves in the vicinity of holes USW G-1, USW G-2, and USW G-3, respectively, are shown in figure 7.6A-C. Also shown are the least horizontal stress gradients (dashed lines) calculated in the absence of topography which, at depth, are the asymptotic bounds to the topographically induced components $S_{h}$. These stress gradients shown as dashed lines in figure 7.6 find their origin at the intersection of the base of the ridge, or horizontal datum (fig. 7.7), and the vertical depth axis.

The least horizontal stresses (shut-in pressures) measured by the hydraulic fracturing technique are shown as open symbols for each hole in figure 7.6. Although the agreement between the calculated least horizontal stresses and the measured components appears to be good, it is clear that topography has little effect on either the calculated or measured stresses in holes USW G-1 and USW G-2 lower on the flanks of the ridge (fig. 7.6A, B; see also fig. 7.7). However, the effect of topography on the calculated stresses in hole USW G-3 under the crest of the ridge is obvious and significant (fig. 7.6C). Here, the calculated component $S_{h}$ shows little tendency to increase with depth for the first $200 \mathrm{~m}$, whereas $S_{v}$ increases steadily with depth, though at a slightly lower rate than shown in figure 7.6A, $B$. Below
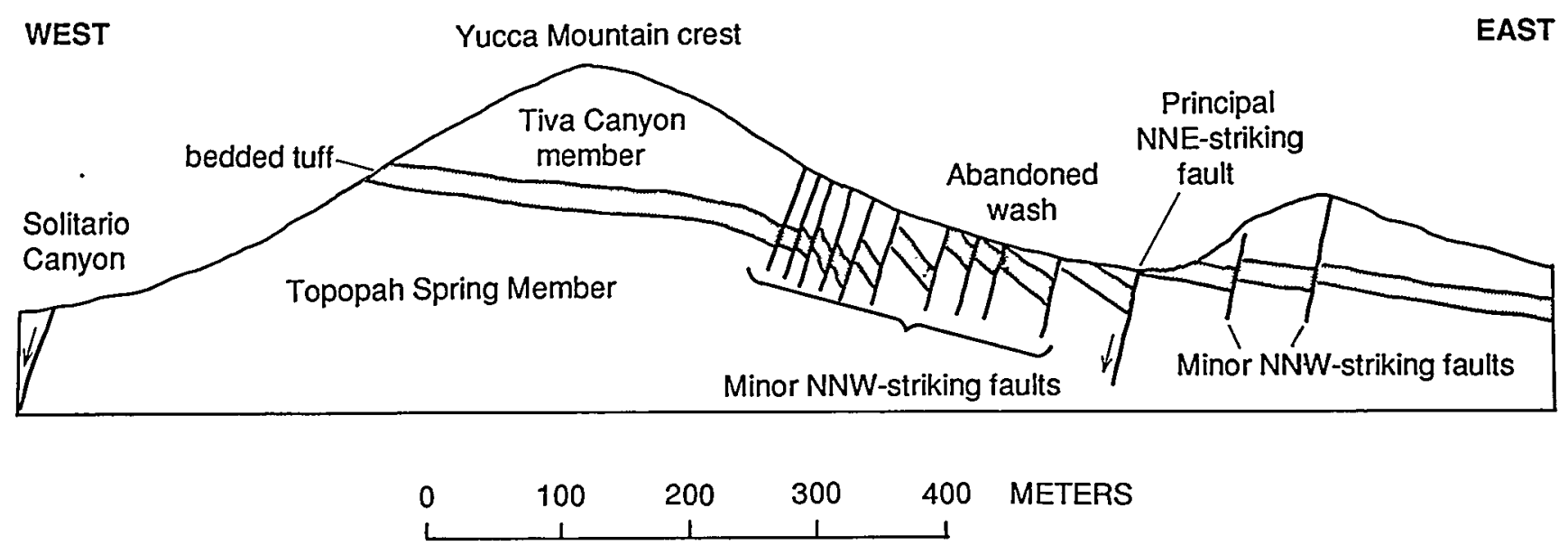

Figure 7.2. Schematic structure section across Yucca Mountain near drill hole USW G-3 showing disposition of normal faults and tilted blocks in ridge. The Tiva Canyon and Topopah Spring units shown are members of the Paintbrush Tuff. No vertical exaggeration. (From Scott and others, 1983.) 
about $800 \mathrm{~m}$, both stress components increase with depth, and the effect of topography is apparent because the magnitudes of these stresses are lower than the calculated and measured stresses at comparable depths in holes USW G-1 and USW G-2 shown in figure 7.6A, $B$. Although not shown in figure 7.6 , this discrepancy finally dissolves at a depth of about $2 \mathrm{~km}$.

The construction shown in figure $7.6 \mathrm{D}$ is obtained by superposing the measurements in figure $7.6 \mathrm{~A}-C$ such that the dashed lines and their origins coincide. In effect, the measured stresses $\left(S_{h}\right)$ in the saturated zone are corrected for topography by adjusting the depths with a vertical shift to a local datum or flat surface that passes through the base of the ridge (fig. 7.7). The distribution obtained in this way (fig. 7.6D) reconciles the differences between measurements in hole USW G-3, and holes USW G-1 and USW G-2 (fig. 7.3).

It is worthwhile to observe that as a result of the vertical shift just described, the differences in the depths to the water table (fig. $7.6 \mathrm{~A}-\mathrm{C}$ ) are also accounted for. The static water

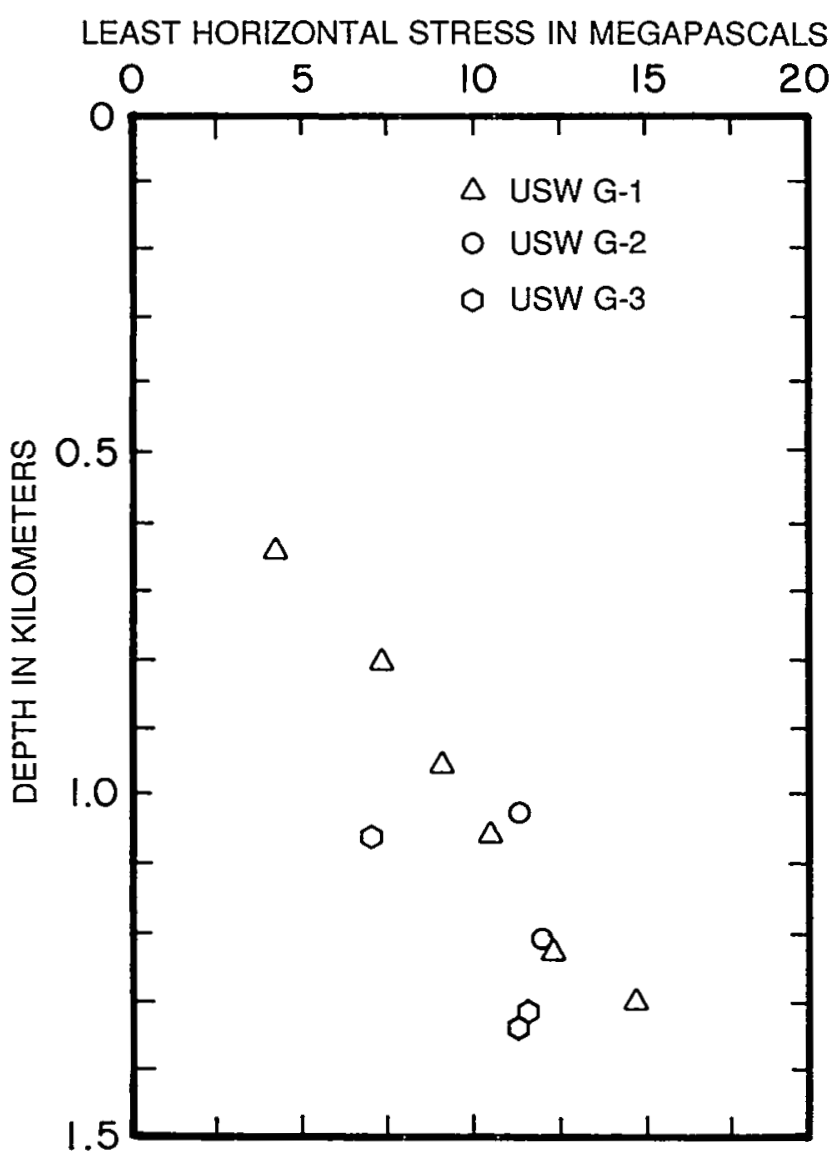

Figure 7.3. Least horizontal stress, $S_{h}$, measured in drill holes USW G-1, USW G-2, and USW G-3 as a function of depth below surface. (From Healy and others, 1984; Stock and others, 1984; and J.M. Stock, written commun., 1984.)
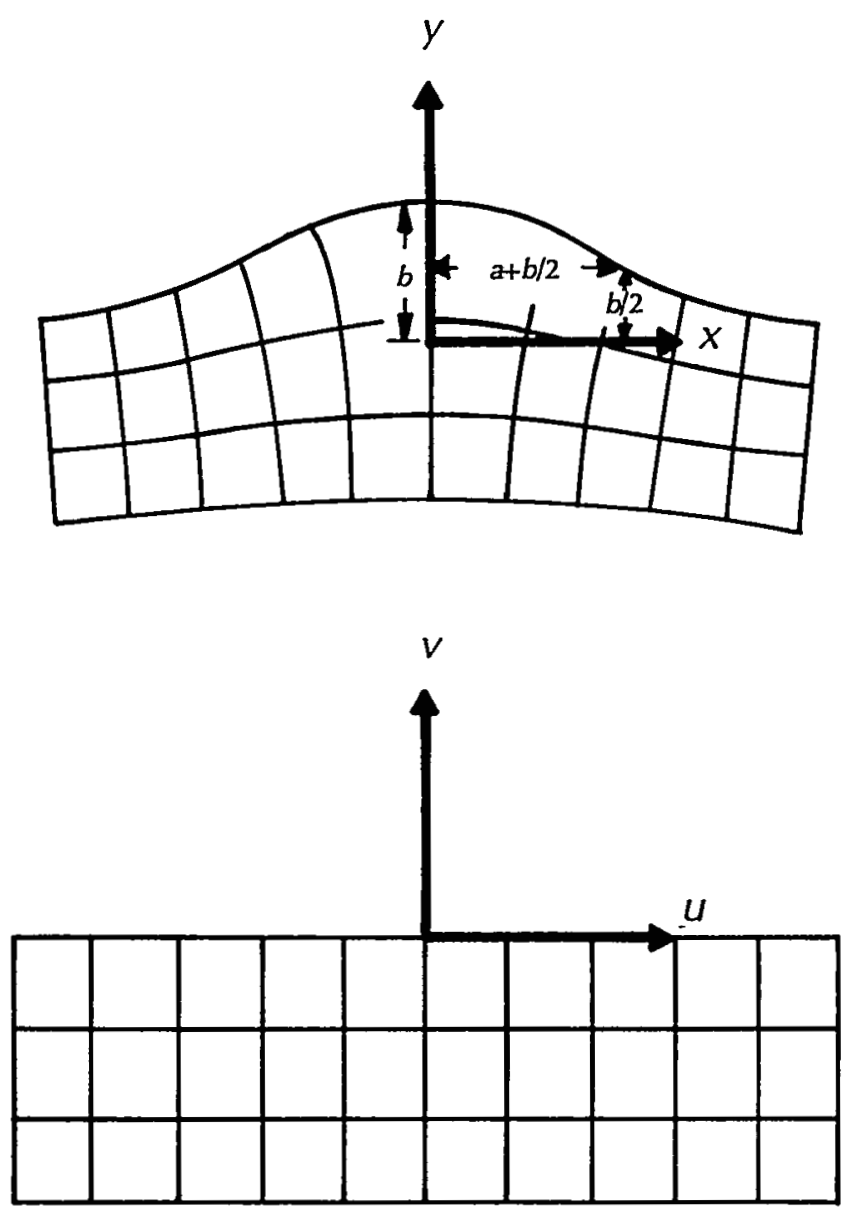

Figure 7.4. Conformal transformation of a symmetric ridge in $x, y$ coordinates into a half-plane in $u, v$ coordinates and definition of parameters $a$ and $b$, which describe the shape of the ridge. See text for discussion of model.

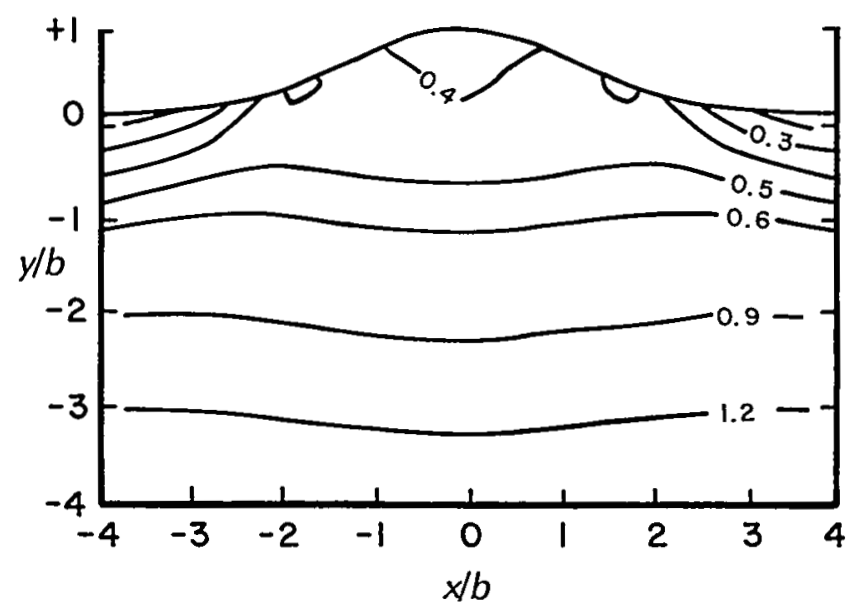

Figure 7.5. Contour plot of dimensionless least-horizontal stress component, $S_{h} / \rho g b$, for a symmetric ridge. Vertical and horizontal scales are normalized by ridge height $b$. 

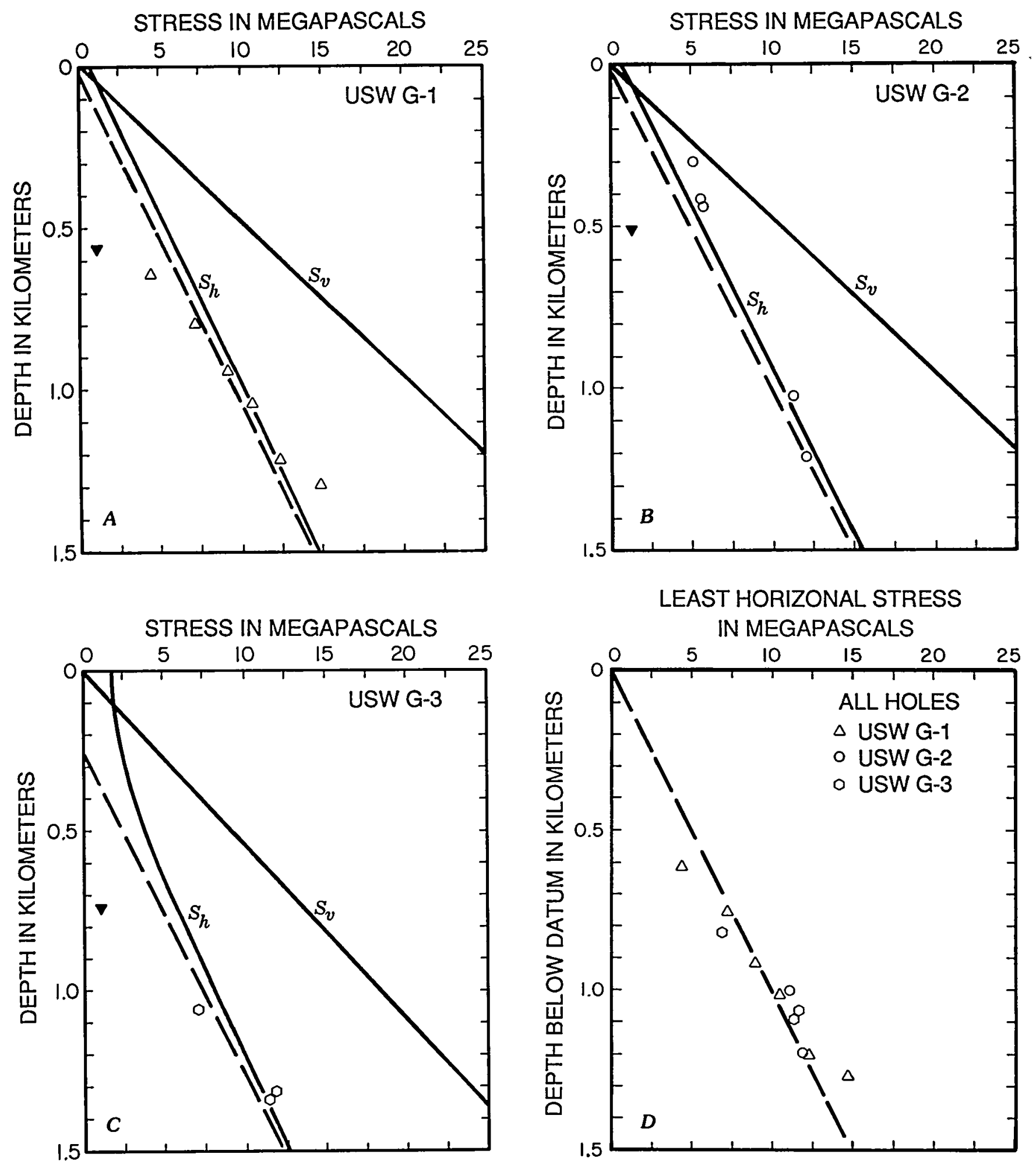

Figure 7.6. Comparison between calculated (solid lines, $S_{h}$ and $S_{v}$ ) and measured stresses (open symbols, $S_{h}$ ) in drill holes. $A$, USW G-1, $B$, USW G-2, and C, USW G-3. Dashed lines represent predicted distribution of $S_{h}$ in the absence of topography; note that they intersect ordinate at different depths. Depths to

static water table indicated by solid, inverted triangles. $D$, Composite plot of all measurements of $S_{h}$ in saturated zone corrected for topography. Ordinate now measures depth relative to base of ridge, which is origin of dashed stress gradients. 


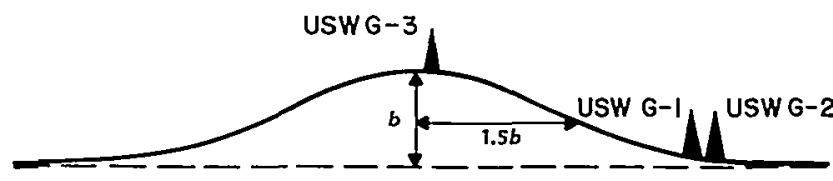

Figure 7.7. Schematic representation of location of drill holes USW G-1, USW G-2, and USW G-3 relative to axial plane of idealized ridge and to local, flat, horizontal datum shown by dashed line. Topographic effect on stresses measured in holes USW G-1 and USW G-2 located on the flank near flat datum is negligible, but effect is pronounced on stresses measured in hole USW G-3 because of its proximity to axial plane atop the ridge.

levels are now found at a near constant depth of about $500 \mathrm{~m}$ below the base of the ridge. This suggests a possible feedback relation between the magnitude of the least horizontal stress component, $S_{h}$, and the position of the water level (fig. 7.6D). A rise in the water table producing a hydrostatic pressure on the order of $S_{h}$ would result in the reopening of conductive fractures and a consequent lowering of the water table to its former level.

The calculated topographically induced stresses are affected by the relative position of the measurement holes with respect to the axial plane of the ridge. Near the crest, the calculated least horizontal stress is greater than the vertical stress to a depth of about $100 \mathrm{~m}$ (fig. 7.6C). Away from the crest, this effect is diminished (figs. 7.6A, $B$ ). Calculations of maximum shear stresses, induced by topography, show that the stress differences are minimized at a depth of about $100 \mathrm{~m}$ under the crest of the ridge. This result is shown in figure 7.6C, where $S_{h}=S_{v}$. If the planestrain assumption is valid at this depth, $S_{H}$ will be close in value to $S_{h}$ and $S_{v}$, and the greatest structural stability would be expected here.

In hole USW G-2, three attempts were made to estimate the shut-in pressures in sections of the hole in the unsaturated zone above the static water table (Stock and others, 1984). These estimates of the shut-in pressures, at which the fractures close, are obtained from pumping rate versus pressure plots; the results are shown as open triangles in figure $7.6 B$ at depths of $295 \mathrm{~m}, 418 \mathrm{~m}$, and $432 \mathrm{~m}$. Because it is not known whether these fractures are freshly formed or already present, and what their attitudes are, some uncertainty exists about the interpretation of the shut-in pressures in terms of the least horizontal stress $\left(S_{h}\right)$ (Stock and others, 1984). What is clear, however, is that the normal stress across the fracture tending to close it should vary with fracture attitude or dip and range between the local calculated values of $S_{h}$ and $S_{v}$, as indicated by the data distribution at shallow depths in figure $7.6 B$.

The calculated values of the greatest horizontal stress $\left(S_{H}\right)$ are only slightly greater than $S_{h}$ because of the planestrain assumption in the analytical model of Savage and others (1985). This result is not in accord with the observations sum- marized earlier. To find an explanation for the observation that the ratio of horizontal-to-vertical stresses $S_{H} / S_{v}$ is about $3 / 4$, we proceed by characterizing the fractured rock material at depth under Yucca Mountain as transversely isotropic in vertical planes subparallel to the ridge.

\section{Fracture Anisotropy}

The problem to be considered here is the determination of the stress distribution in anisotropic rock induced by gravitational loading in the absence of the effects of topography. Solutions are given by Amadei and others (1987) for the case where the planes of transverse isotropy are vertical. Horizontal stresses parallel and perpendicular to the anisotropy are $S_{H}$ and $S_{h}$, respectively. The governing equations are

$$
S_{h} / S_{v}=v^{\prime}(1+v) /\left(1-v^{\prime 2} E / E^{\prime}\right)
$$

and

$$
S_{H} / S_{v}=\left(v+v^{\prime 2} E / E^{\prime}\right) /\left(1-v^{\prime 2} E / E^{\prime}\right)
$$

where $S_{v}=\rho g h$, and $E, E^{\prime}, v$, and $v^{\prime}$ are the elastic constants. The Poisson's ratios, defined in terms of strain ratios and directions with reference to the planes of transverse isotropy, are $\nu=-\varepsilon_{H} / \varepsilon_{\nu}=-\varepsilon_{v} / \varepsilon_{H}$ and $\nu^{\prime}=-\varepsilon_{H} / \varepsilon_{h}=-\varepsilon_{v} / \varepsilon_{h}$. The Young's moduli parallel and perpendicular to the anisotropy are $E$ and $E^{\prime}$, respectively.

As mentioned above, the stresses at Yucca Mountain are such that $S_{H} / S_{v} \cong 3 / 4$ and $S_{h} / S_{v}=1 / 2$. If we assume, as before, that $\nu=0.32$ (Ellis and Swolfs, 1983), then equations 1 and 2 may be solved simultaneously for the two unknowns, $\nu^{\prime}$ and $E / E^{\prime}$. Because of the uncertainty in the measured magnitude of $S_{H}$ at Yucca Mountain, the results are given in table 7.1 for a range of $S_{H} / S_{v}$ ratios. The results show a weak dependence on $v^{\prime}$, but a strong dependence on the modulus ratio. For the extreme case, where $S_{H} / S_{v}=3 / 4$, the modulus contrast is a factor of 3 , although it decreases rapidly as the stress ratio is diminished. In a fractured medium, such as that found in Yucca Mountain, this range of modulus contrast (table 7.1) may not be altogether unrealistic (Pratt and others, 1977).

Table 7.1. Properties of transversely isotropic material

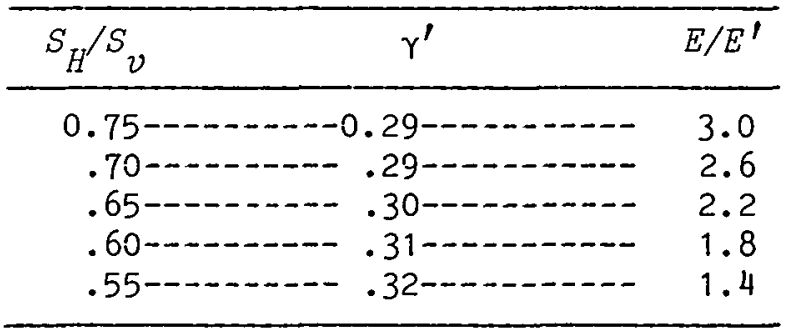




\section{CONCLUSIONS}

We have analyzed the measured stresses at Yucca Mountain by using two separate theoretical models. The stress analyses suggest that the measured stresses at shallow depths in the saturated zone are predominantly of gravitational origin, a conclusion that is compatible with the fact that Yucca Mountain is seismically quiescent. Furthermore, the stresses are affected by fracture-induced anisotropy, and selectively, by topography. Using only a single measured value of Poisson's ratio as a modeling parameter, we show that the reduced stresses measured in drill hole USW G-3 are due to gravitational spreading beneath the ridge. The method of analysis also allows for the adjustment of these stresses modified by topography.

The data, now corrected for the topographic effect, may be interpreted in terms of the Coulomb criterion for frictional sliding on suitably oriented faults (Jaeger and Cook, 1979, p. 95). The implications of such an interpretation are presented by Stock and Healy in chapter 6 .

Stress states above the saturated zone at repository depths remain enigmatic because of the paucity of data. However, the model for topographically induced stresses provides a basis for predicting the stress magnitudes, and the degree of structural stability, at these depths in the unsaturated zone.

\section{REFERENCES CITED}

Amadei, Bernard, Savage, W.Z., and Swolfs, H.S., 1987, Gravitational stresses in anisotropic rock masses: International Journal of Rock Mechanics, Mining Sciences, and Geomechanical Abstracts, v. 24, p. 5-14.

Carr, M.D., Waddell, S.J., Vick, G.S., Stock, J.M., Manson, S.A., Harris, A.G., Cork, B.W., and Byers, F.M., 1986, Geology of drill hole UE25p\#1-A test hole into pre-Tertiary rocks near Yucca Mountain, southern Nevada: U.S. Geological Survey Open-File Report 86-175, 87 p.

Ellis, W.L., and Swolfs, H.S., 1983, Preliminary assessment of in-situ geomechanical characteristics in drill hole USW-G-1, Yucca Mountain, Nevada: U.S. Geological Survey Open-File Report 83-401, 18 p.
Haimson, B.C., and Fairhurst, Charles, 1967, Initiation and extension of hydraulic fractures in rock: Journal of the Society of Petroleum Engineers, v. 7, p. 310-318.

Healy, J.H., Hickman, S.H., Zoback, M.D., and Ellis, W.L., 1984, Report on televiewer log and stress measurements in core hole USW-G1, Nevada Test Site: U.S. Geological Survey Open-File Report 84-15, 47 p.

Jaeger, J.C., and Cook, N.G.W., 1979, Fundamentals of rock mechanics: New York, Chapman and Hall, 593 p.

Mooney, W.D., Snyder, D.B., and Hoffman, L.R., 1982, Seismic refraction and gravity modeling of Yucca Mountain, Nevada Test Site, southern Nevada [abs.]: Eos, Transactions of the American Geophysical Union, v. 63, p. 1100.

Pratt, H.R., Swolfs, H.S., Brace, W.F., Black, A.D., and Handin, J.W., 1977, Elastic and transport properties of an in situ jointed granite: International Journal of Rock Mechanics, Mining Sciences, and Geomechanical Abstracts, v. 14, p. 35-45.

Roseboom, E.H., 1983, Disposal of high-level nuclear waste above the water table in arid regions: U.S. Geological Survey Circular 903,21 p.

Savage, W.Z., Swolfs, H.S., and Powers, P.S., 1985, Gravitational stresses in long symmetric ridges and valleys: International Journal of Rock Mechanics, Mining Sciences, and Geomechanical Abstracts, v. 22, p. 291-302.

Scott, R.B., and Bonk, Jerry, 1984, Preliminary geologic map of Yucca Mountain with geologic sections, Nye County, Nevada: U.S. Geological Survey Open-File Report 84-494, 9 p., scale $1: 12,000$.

Scott, R.B., and Castellanos, Mayra, 1984, Stratigraphic and structural relations of volcanic rocks in drill holes USW GU-3 and USW G-3, Yucca Mountain, Nye County, Nevada: U.S. Geological Survey Open-File Report 84-491, 121 p.

Scott, R.B., Spengler, R.W., Diehl, S.F., Lappin, A.R., and Chornack, M.P., 1983, Geologic character of tuffs in the unsaturated zone at Yucca Mountain, southern Nevada, in Mercer, J.W., Rao, P.S.C. and Marine, I.W., eds., Role of the unsaturated zone in radioactive and hazardous waste disposal: Ann Arbor, Mich., Ann Arbor Science, p. 289-335.

Snyder, D.B., and Carr, W.J., 1984, Interpretation of gravity data in a complex volcano-tectonic setting, southwestern Nevada: Journal of Geophysical Research, v. 89, p. 10,193-10,206.

Stock, J.M., Healy, J.H., and Hickman, S.H., 1984, Report on televiewer log and stress measurements in core hole USW G-2, Nevada Test Site: U.S. Geological Survey Open-File Report 84-172, $31 \mathrm{p}$.

Winograd, I.J., 1981, Radioactive waste disposal in thick unsaturated zones: Science, v. 212, p. 1457-1464. 


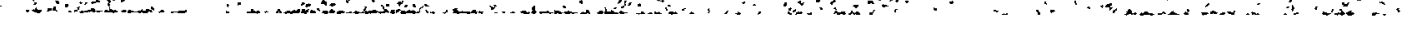




\title{
8. Preliminary Study of Quaternary Faulting on the East Side of Bare Mountain, Nye County, Nevada
}

\author{
By Marith C. Reheis
}

\section{CONTENTS}

\author{
Abstract 103 \\ Introduction 103 \\ Acknowledgments $\mathbf{1 0 5}$ \\ Geomorphic interpretation 105 \\ Field reconnaissance 105 \\ Faults in Tertiary and older Pleistocene units 105 \\ Faults in younger Pleistocene and Holocene units 106 \\ Faults in bedrock units 109 \\ Summary 110 \\ References cited $\mathbf{1 1 0}$
}

\section{Abstract}

Active faults bound the east side of Bare Mountain. Geomorphic features, stratigraphy, and soil development indicate that two 3-km-long segments of the range-front fault probably last moved in late Pleistocene or Holocene time. Other segments of the fault have been quiescent since the late Pleistocene. Both upper Pleistocene and Holocene deposits bury many faults east of the north end of Bare Mountain.

Two prospect pits on the range-front fault reveal evidence of recurrent late Quaternary movements. Both older and younger deposits in one pit are faulted, but fractures in the older unit do not extend up into the younger unit. Soil development shows that the older and younger fault episodes are probably late Pleistocene and Holocene, respectively, in age. Another pit shows carbonate-cemented fractures with slickensides in an upper Pleistocene deposit, suggesting at least two late Pleistocene or Holocene fault movements.

Tertiary to middle Pleistocene deposits show evidence of recurrent faulting in many locations. Faults in these deposits are pervaded by secondary $\mathrm{CaCO}_{3}$ and silica that commonly exhibit slickensides.

\section{INTRODUCTION}

The east range front of Bare Mountain trends northsouth and lies about $15 \mathrm{~km}$ west of the proposed nuclear waste disposal site at Yucca Mountain (fig. 8.1). Bare Mountain consists of complexly faulted Paleozoic rocks intruded by
Tertiary rhyodacitic dikes (Cornwall and Kleinhampl, 1961). The range front is structurally controlled by a system of normal faults that have remained active during Quaternary time (Swadley and others, 1984; Carr, 1984). Several small earthquakes (less than magnitude 3) from 1978 to 1984 had epicenters located along the range-front fault (Rogers and others, 1983; Carr, 1984). However, previous workers have mapped few faults in the fan alluvium that fringes the mountain front, except in the area east of the north end of Bare Mountain.

Preliminary interpretation of mapping, soil studies, and aerial photographs indicates that the Bare Mountain rangefront fault cuts deposits of Pleistocene and probable Holocene age in numerous places. Evidence for recurrent activity on this fault in middle Pleistocene and Holocene time is found in several localities.

The ages of Quaternary deposits are estimated using soil development and surface characteristics (Hoover and others, 1981). The Soil Development Index of Harden (1982; see also Harden and Taylor, 1983) is used to quantify soil properties in order to compare the ages of soils in different areas. Soils were compared to those developed in similar climates on dated alluvial deposits in Fortymile Wash, $25 \mathrm{~km}$ east of Bare Mountain (Taylor, 1985) and in Kyle Canyon, $115 \mathrm{~km}$ to the southwest (Sowers, 1985). Although the Fortymile Wash area is closer, the Kyle Canyon soils formed on carbonate-rich deposits similar to those at Bare Mountain. Soils on the calcareous Kyle Canyon and Bare Mountain fans with similar characteristics, such as thickness of the $\mathrm{A}$ and $\mathrm{B}$ horizons and stage of pedogenic $\mathrm{CaCO}_{3}$ and silica accumulation, should be of comparable age.

In general, the terms Holocene, younger Pleistocene, and older Pleistocene as used in this report correspond, respectively, to units Q1a-c, Q2b-c, and QTa of Hoover and others (1981). However, age assignments of these deposits in Swadley and others (1984) along the Bare Mountain range front may be too old. For example, the latter workers used petrocalcic horizons to identify units Q2c and QTa, believed to be older than $250 \mathrm{ka}$ (thousand years). Units with similar development were originally dated with the uranium-trend method in relatively noncalcareous alluvium on the Nevada Test Site (Hoover and others, 1981). Many of the Bare Mountain alluvial fans are mainly composed of carbonate 


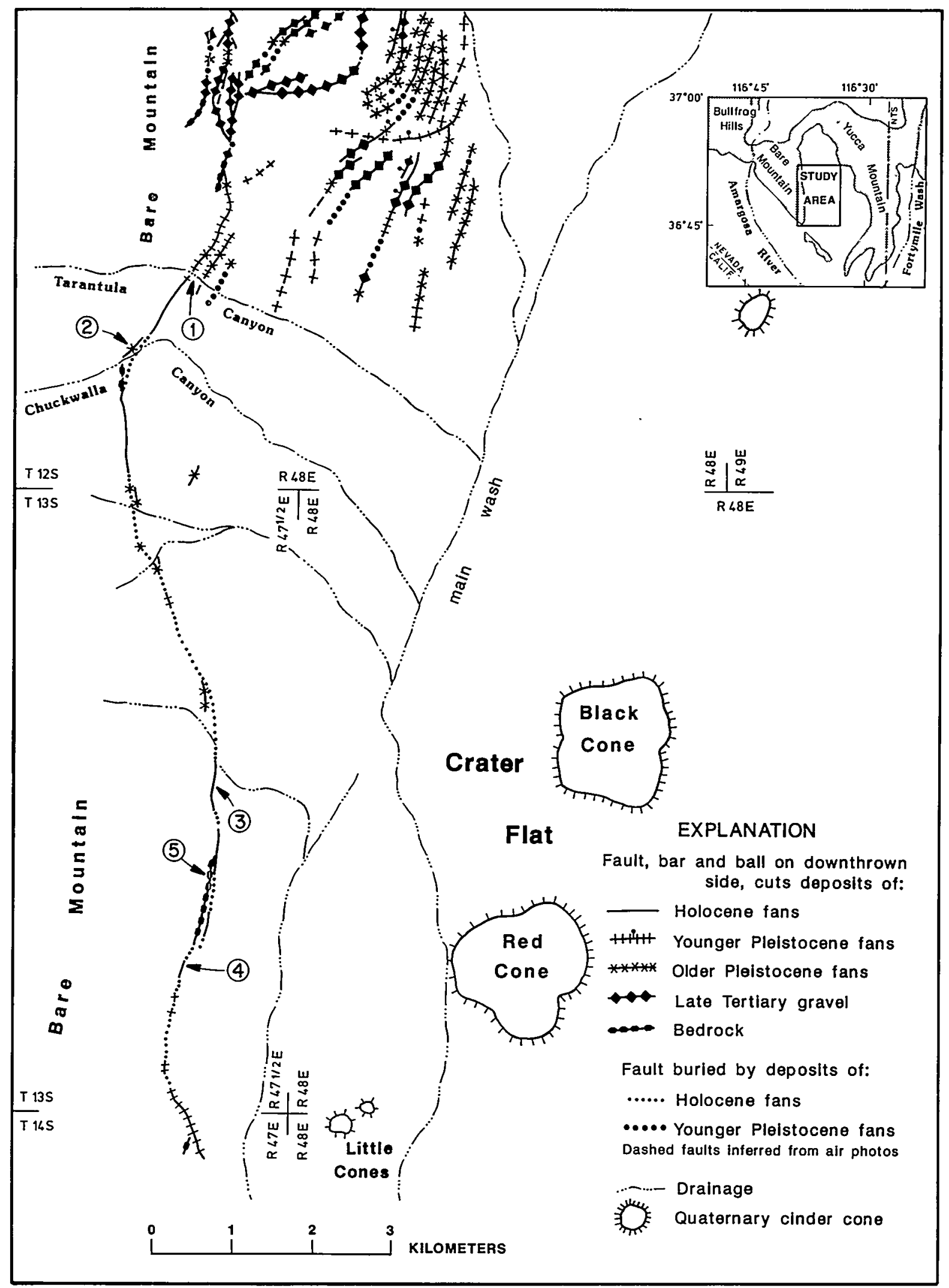

Figure 8.1. Quaternary faulting on east side of Bare Mountain. Faults with no bar and ball are down to the south or east. Circled numbers refer to sites discussed in text and other figures. 
sediments in which pedogenic $\mathrm{CaCO}_{3}$ probably forms much more rapidly than in areas of other provenance. Petrocalcic horizons are found in similar soils dated with uraniumthorium methods at $120 \mathrm{ka}$ (Sowers, 1985) on calcareous fans in Kyle Canyon. Thus, soils formed in calcareous alluvium are probably younger than soils with comparable amounts of $\mathrm{CaCO}_{3}$ formed in noncalcareous alluvium.

\section{Acknowledgments}

This work was performed in cooperation with the U.S. Department of Energy, Nevada Nuclear Waste Storage Investigations Project. Discussions with W C Swadley, J.W. Whitney and E.M. Taylor gave useful perspectives. G. Vick provided able field assistance, and C.C. Reheis provided entertainment.

\section{GEOMORPHIC INTERPRETATION}

Geomorphic characteristics of the Bare MountainCrater Flat area indicate recurrent Quaternary faulting (fig. 8.1, and map of Swadley and others, 1984). The Bare Mountain front is steep, with faceted spurs. Drainages are deeply incised within the mountains, but are aggrading on the surface of steeply sloping Holocene alluvial fans that bury older fans adjacent to the mountain front south of Tarantula Canyon. This relation suggests that recent uplift along the range front has caused drainages to deposit young alluvium over older alluvium (Bull, 1964). Holocene deposits north of Tarantula Canyon are mainly confined to arroyos cut into older deposits, which suggests that faulting there has not been as recent. This unequal distribution of Holocene fans along the Bare Mountain front indicates a local tectonic control of stream gradients rather than a regional climatic control.

Geomorphic features on aerial photographs (scale 1:12,000) also indicate probable Quaternary faults. Linear features such as brush lines and disturbed ground (extensive areas of rodent burrows) commonly mark the traces of faults that offset Quaternary alluvium in the area of the Nevada Test Site. Such features are abundant in Pleistocene and Holocene deposits along the range-front fault, and in Pleistocene deposits north of the Tarantula Canyon drainage. Only two obvious scarps along the range front are recognized: one on the south side of Tarantula Canyon (site 1 , fig. 8.1), and the other, now destroyed by recent mining activity, on the range-front fault about $1.5 \mathrm{~km}$ south of the boundary between townships 12 and 13 (fig. 8.1). Both scarps offset fans which appear to be of middle or late Pleistocene age. Many small drainages appear to be offset along the range-front fault as they debouch onto the piedmont slope. Whether the drainages are following weaknesses caused by recent faulting or the bedrock is not known. As a result of these active channels at the bedrock-alluvium contact, exposures of the range-front fault are rare.

\section{FIELD RECONNAISSANCE}

The faults on figure 8.1 were mapped on the basis of exposures in arroyos and prospect pits and from aerial photographs. Arroyos cutting older Pleistocene deposits commonly expose steeply dipping fault zones with secondary calcium carbonate $\left(\mathrm{CaCO}_{3}\right)$ and amorphous silica. These zones correspond to linear features in aerial photographs (sites 1 and 2, fig. 8.1). Because faults in young deposits are not cemented with $\mathrm{CaCO}_{3}$ or silica, they are more difficult to discern. Linear zones of disturbed ground and abrupt changes in the gradients of fan surfaces are believed to indicate faults in younger deposits. Three prospect pits (sites 3,4 , and 5, fig. 8.1) expose faults in upper Pleistocene or Holocene deposits. Some fault segments along the range front pass from alluvium into bedrock (site 5).

Most of the range-front faults dip between $60^{\circ}$ to $80^{\circ}$ eastward. An exception is the $35^{\circ}-45^{\circ}$ southeastwarddipping segment of the range-front fault that strikes northeast from Chuckwalla Canyon (fig. 8.1). This segment projects into a gently dipping normal fault in bedrock that continues to the head of Chuckwalla Canyon (Cornwall and Kleinhampl, 1961; M.D. Carr, oral commun., 1985).

Offset is difficult to determine on most of the faults because of poor exposures and the uniformity of the alluvial fan deposits. Assuming that the faults are normal, as are many local faults in bedrock, most of the offsets are down to the east or south. Antithetic faults seem to be present at sites 1 and 4 (fig. 8.1), but exposures are poor and excavations are needed to determine their nature and extent.

\section{Faults in Tertiary and Older Pleistocene Units}

Arroyo walls and prospect pits expose faults in older alluvial fans along linear features noted on aerial photographs. Faults are most abundant in the area north of the Chuckwalla Canyon drainage (fig. 8.1). The fault zones are typically $0.25-1 \mathrm{~m}$ wide (fig. $8.2 A$ ). The zones are always cemented with secondary $\mathrm{CaCO}_{3}$ and sometimes amorphous silica, which apparently precipitate from ground water or from rainwater and surface runoff percolating through the fault zones. A fault zone is commonly accompanied by several thinner, carbonate-cemented fractures within $30 \mathrm{~m}$ of the main zone. These fractures show no offset but are probably fault-related, as they occur only in areas that are faulted.

Clasts within the fault zones are usually oriented with their long axes parallel to the boundaries of the cemented zone. Presumably the clasts were oriented by drag along the fault, although near-vertical orientations can also result when clasts fall into open surface fractures caused by faulting (K.L. Pierce, oral commun., 1985; Crone and others, 1985), or into animal burrows. The latter two mechanisms usually 


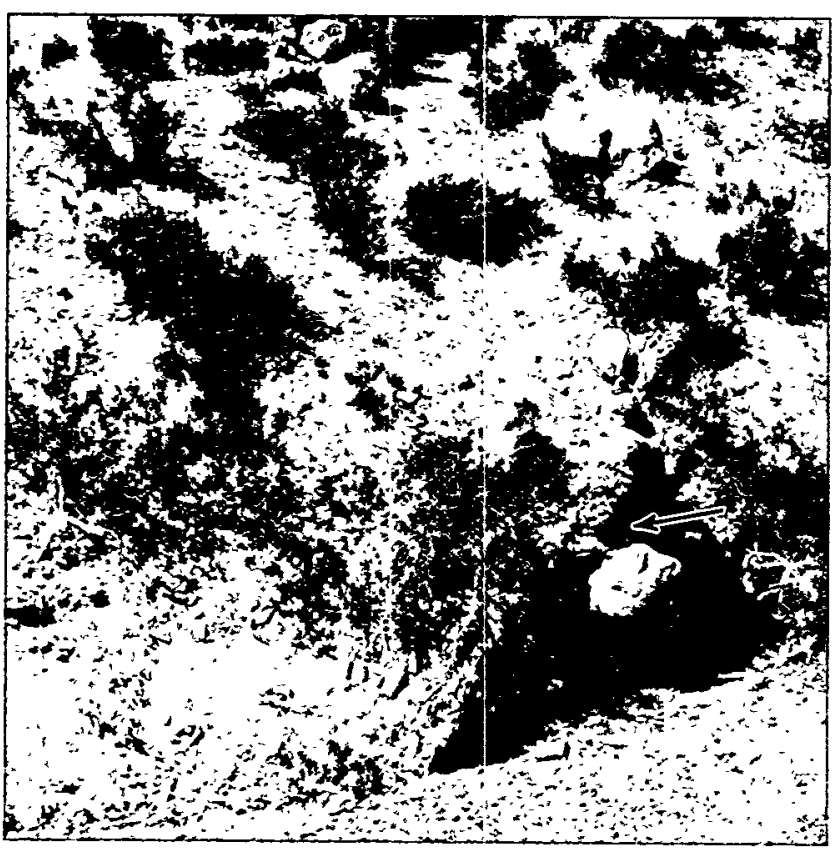

$A$

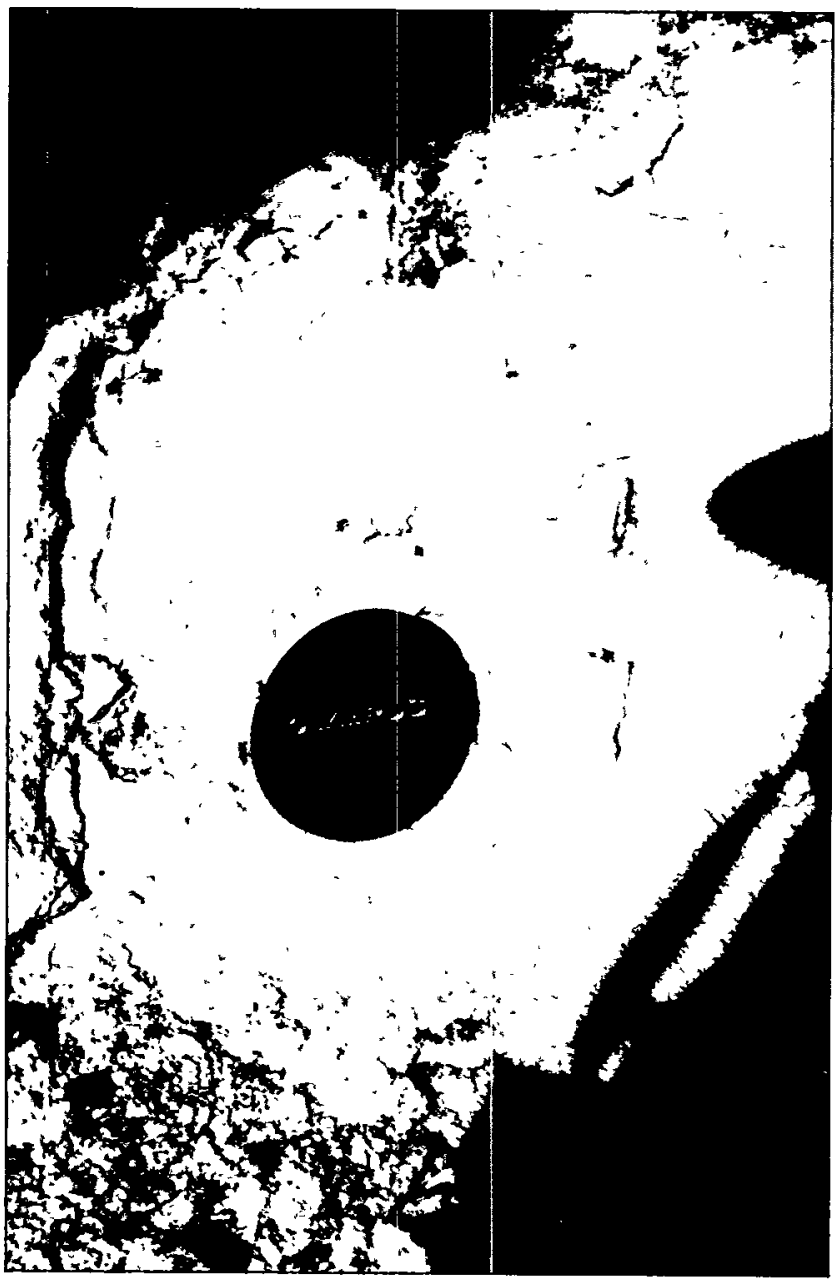

$B$ result in a wide range of clast orientations, however, rather than one preferential orientation.

Multiple offsets have occurred on a number of the faults in older units. The $\mathrm{CaCO}_{3}$ and silica cement within the fault zones, emplaced after one or more fault movements, commonly exhibits slickensides that indicate the fault moved after at least some of the cementation occurred (fig. 8.2B). The slickensides on exposures of the range-front fault are usually perpendicular to the local trend of the mountain front.

Accurate ages of the faults in older alluvial units are not known. Some of the faults cut Tertiary gravel and (or) older Pleistocene fans but are buried by younger Pleistocene and Holocene alluvium (fig. 8.1); these faults are therefore probably middle Pleistocene in age or older. Other faults cut both older and younger Pleistocene units, but are buried by Holocene alluvium; these may be late Pleistocene in age. Extensive $\mathrm{CaCO}_{3}$ cementation along a fault zone probably indicates that at least one movement of the fault occurred in late Pleistocene time or earlier, for the cementation process is slow. Faults in upper Pleistocene and Holocene deposits are not cemented, although secondary $\mathrm{CaCO}_{3}$ does occur locally along young faults.

One radiometric date was obtained by the uraniumseries method for a cemented fault zone (site 2, fig. 8.1) along Bare Mountain (B.J. Szabo, oral commun., 1985). The age of secondary silica with slickensides (fig. 8.2B) is $>350 \mathrm{ka}$. Thus, the fault movement that permitted cementation to begin probably predates $350 \mathrm{ka}$, but the age of the movement that produced the slickensides is known only to be younger than the initiation of cementation.

\section{Faults in Younger Pleistocene and Holocene Units}

In general, subsurface exposures of faults in young alluvial units are poor because they are unconsolidated, so a fault origin for many of the linear features seen from the air on the surface of these units is equivocal. Brush lines in these units may be caused by the plants rooting through thin, young deposits into fault zones in underlying older deposits. However, two prospect pits (sites 3 and 4, fig. 8.1) reveal good evidence of late Pleistocene or Holocene movement on the Bare Mountain range-front fault, and two other pits (site 5) provide supporting evidence for recent faulting.

Figure 8.2. Secondary cementation on faults. $A$, Secondary $\mathrm{CaCO}_{3}$ cementing zone along fault cutting younger Pleistocene alluvium on south side of Tarantula Canyon at site 1 ; fault zone is marked by hammer on large white boulder in foreground. $B$, Slickensides on secondary silica in fault exposed in prospect pit north of Chuckwalla Canyon at site 2 . The silica is dated at $>350$ ka (B.J. Szabo, oral commun., 1985). See figure 8.1 for site locations.

106 Geologic and Hydrologic Investigations, Yucca Mountain, Nevada 
A prospect pit exposes a small alluvial fan deposited against faulted Paleozoic limestone (site 3, fig. 8.1). A probable fault cuts the alluvium parallel to and about $1 \mathrm{~m}$ east of the bedrock outcrop (fig. 8.3A), where a gravelly bed of alluvium adjacent to the bedrock stops at the fault and appears to be cut by it. Clasts in the deposit are oriented parallel to the fan surface slope except along the fault zone, where the clasts are parallel to the fault (fig. 8.3B). The area of the presumed fault has animal burrows, but the clasts in this area have fairly uniform orientation; clasts that fell into burrows would probably have more randomly distributed orientations.

The surface morphology and the soil developed on this fan suggest that the fan and the subsequent faulting are probably Holocene in age and no older than late Pleistocene in age. The surface is bouldery and has little or no desert pavement. These characteristics are typical of late Pleistocene and Holocene surfaces in the area (Hoover and others, 1981). The soil has a weak, sandy, vesicular A horizon, $2-3 \mathrm{~cm}$ thick, and a slightly oxidized, calcareous $\mathrm{B}$ horizon. $\mathrm{CaCO}_{3}$ development consists of coats up to $1 \mathrm{~mm}$ thick on clast bottoms. These properties are typical of soils developed on deposits believed to be late Pleistocene and early Holocene in age in Fortymile Wash (Taylor, 1985), and soils on a 5- to 15-ka fan in Kyle Canyon.

Evidence of two successive movements of the rangefront fault is exposed in an excavation at site 4 (fig. 8.1). The north wall of this pit (fig. 8.4A) exposes gravelly sediment in fault contact with Paleozoic limestone. The fault plane strikes N. $35^{\circ} \mathrm{E}$. and dips $58^{\circ} \mathrm{SE}$. Clasts as large as boulders are oriented parallel to the fault plane, in a zone about $50 \mathrm{~cm}$ wide along the bedrock surface. Most of the clasts away from this zone are oriented parallel to the ground surface or are randomly oriented. Two Quaternary deposits are recognized in the excavation. The younger deposit disconformably overlies a buried soil formed in the older deposit. Both deposits are very poorly sorted and poorly stratified, and in many places are clast-supported with very little fine matrix. These deposits may have accumulated at the base of a free face formed by faulting (Wallace, 1977).

The buried soil contains numerous vertical fractures (fig. 8.4B) and has two fractures that parallel the main fault plane (fig. 8.4A). The east fracture is lined by secondary $\mathrm{CaCO}_{3}$ (fig. 8.4B), but shows no evidence of offset. Movement may have occurred on the west fracture, because some large clasts have been rotated parallel to it (fig. 8.4A). All of the fractures terminate upward at the top of the buried soil. This soil is well preserved and may have been rapidly buried, perhaps in part by colluvium shed from the fault scarp.

The older deposit is probably middle Pleistocene in age, based on soil morphology. This buried soil has remnants of an A horizon overlying well-developed structure in the $\mathrm{B}$ horizon. Pedogenic $\mathrm{CaCO}_{3}$ and silica coat clast bottoms and occur in the finer matrix between clasts, but do not cement the soil horizons. The $\mathrm{CaCO}_{3}$ and silica morphology is similar to that of soils formed on middle Pleistocene(?) deposits $(\mathrm{Q} 2 \mathrm{~b})$ in Fortymile Wash that are believed to be 145-160 ka in age (Swadley and others, 1984). Typical profile-index values of the Soil Development Index for soils on Q2b deposits range from 28 to 44 (Taylor, 1985); the profile index value calculated for the buried soil is 39 . These values are probably comparable because this particular deposit contains relatively large proportions of quartzite rather than carbonate gravel, in contrast to most of the Bare Mountain alluvium. Thus, the parent material for the soils in this prospect pit resembles the carbonate-poor alluvium of uranium-trend-dated soils on the Nevada Test Site more closely than the carbonate-rich alluvium of soils at Kyle Canyon.

The episode of faulting that fractured the buried soil must have occurred after most of the soil properties were developed, but before the deposition of the overlying material. The buried fractures are very clear and well preserved. Had the fractures formed before most of the soil properties, the fractures would have been disrupted and destroyed by processes such as bioturbation during subsequent soil formation.

The younger deposit has definitely been faulted. Clasts near the main fault plane parallel the bedrock (fig. 8.4A). These clasts must have been oriented within the younger alluvium, for the dip angle is too steep to be maintained as a free face. At the contact between the younger deposit and the buried soil is a laminar $\mathrm{CaCO}_{3}$ layer $1-2 \mathrm{~cm}$ thick (fig. 8.4B). This layer is continuous across the exposure but stops at the zone of oriented clasts near the fault plane. Pieces of laminar $\mathrm{CaCO}_{3}$ oriented parallel to the fault plane occur within this zone about $1.75 \mathrm{~m}$ above the continuous laminar layer (fig. 8.4A). The laminar layer resembles those found in petrocalcic soil horizons. However, it is unlikely to have formed as part of the buried soil because the layer overlies the B horizon of this soil; such layers normally occur within or below B horizons of well-drained soils. The laminar layer probably formed after the younger deposit buried the older one, because the buried soil, being compact and weakly cemented, acted as a permeability barrier to percolating, $\mathrm{CaCO}_{3}$-saturated water. If the oriented pieces of laminar $\mathrm{CaCO}_{3}$ were derived from the laminar layer, they indicate that the fault moved at least $1.75 \mathrm{~m}$ vertically after deposition of the younger unit and formation of the laminar layer at its base. The exposed limestone bedrock has a degraded scarp of comparable height.

The morphology of the surface soil formed on the younger deposit suggests that this deposit and the fault movement that affected it are Holocene in age. Pedogenic $\mathrm{CaCO}_{3}$ and silica occur only as coats on clast bottoms; the A horizon is sandy, and the B horizon is weakly oxidized. These characteristics are-similar to those of Holocene soils in Kyle Canyon. The profile-index value of the Soil Development Index for the surface soil is 20 , which corresponds to values for soils on lower Holocene deposits (unit Q1c, believed to be about $9 \mathrm{ka}$ ) in Fortymile Wash (Taylor, 1985). 


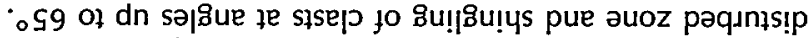

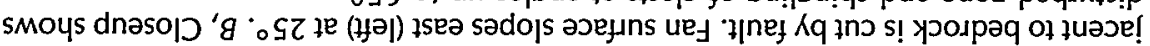

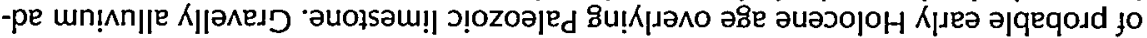

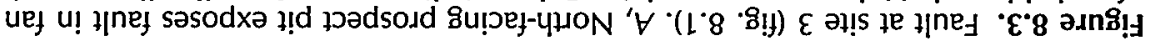
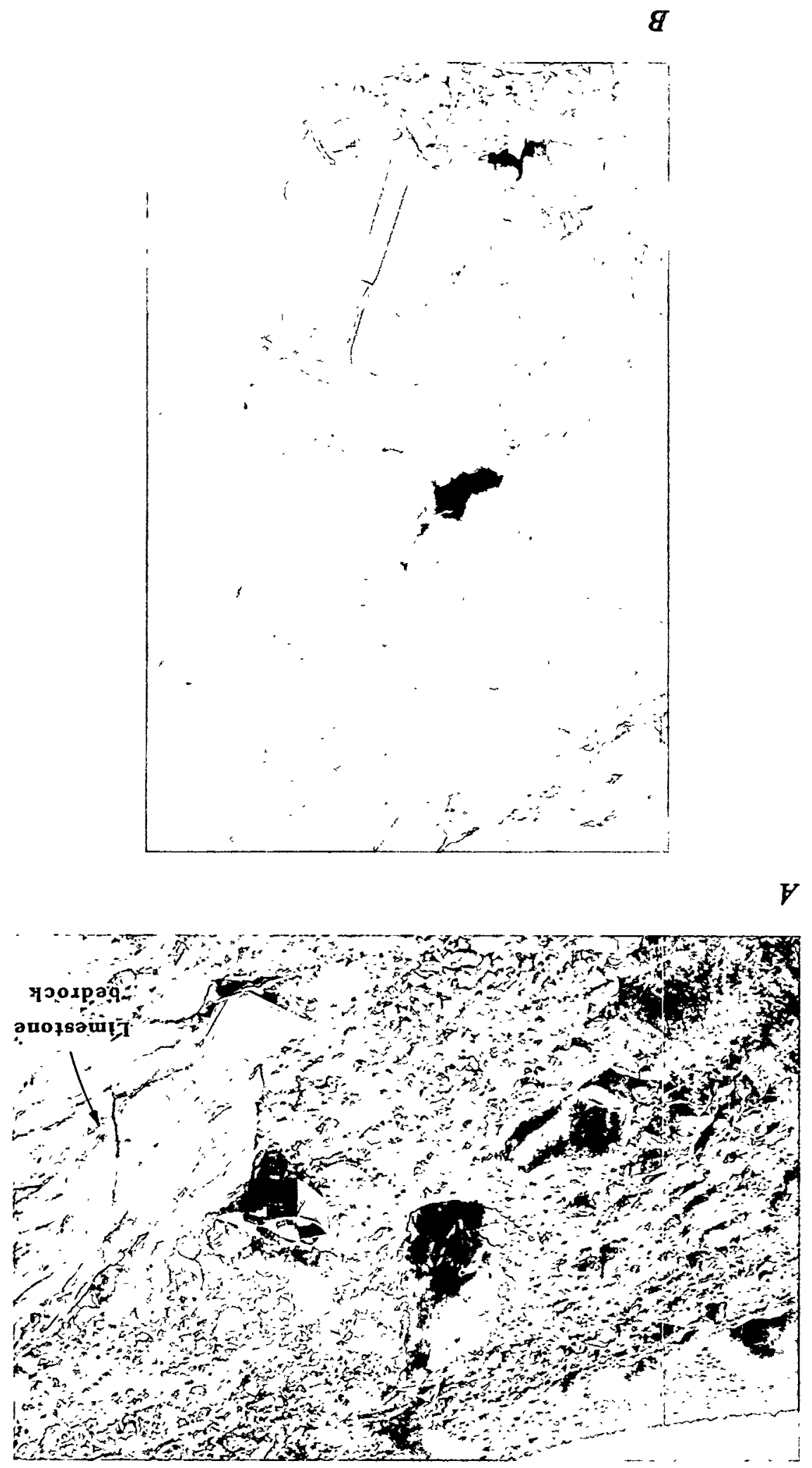

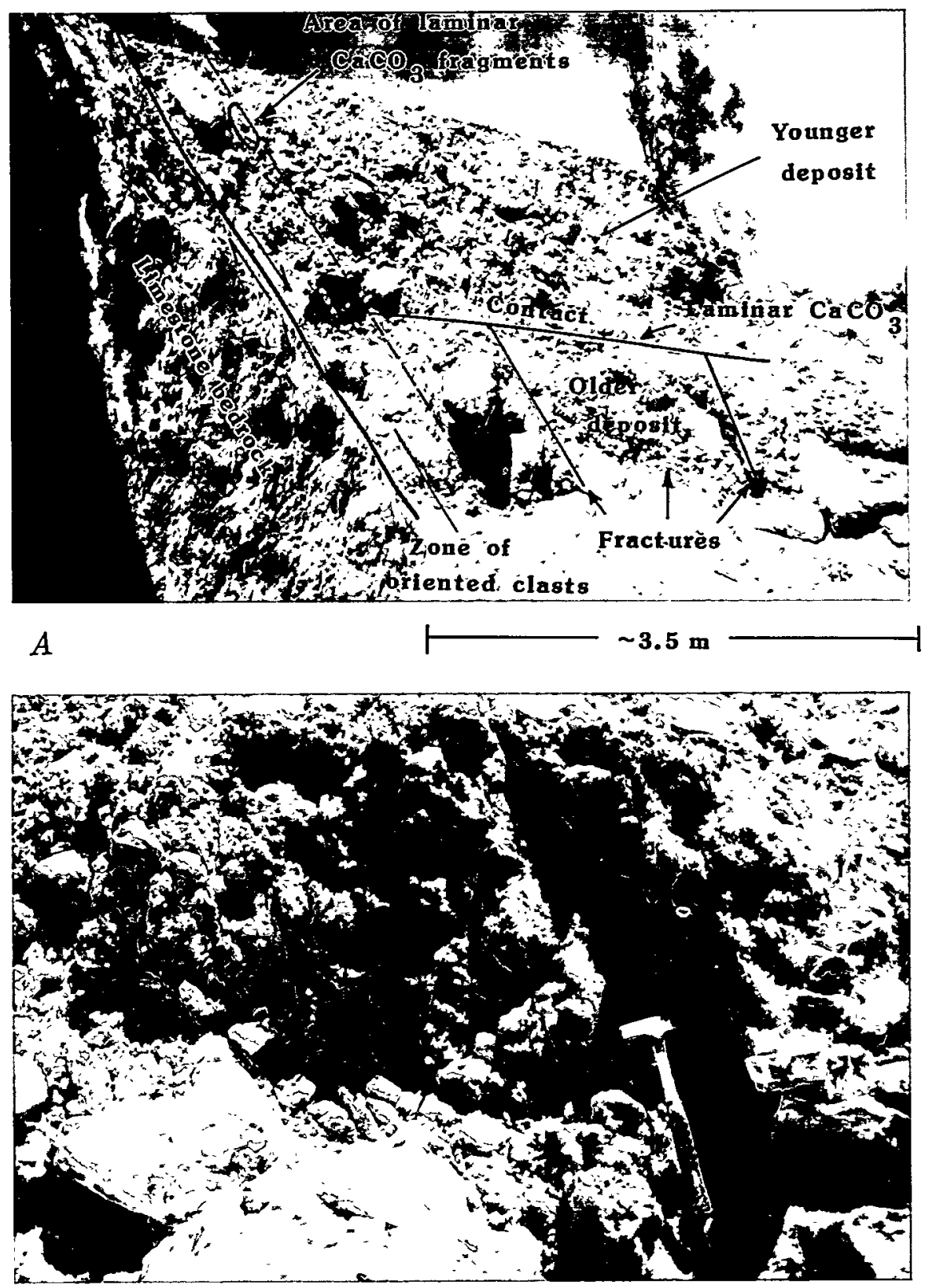

$B$

Figure 8.4. Prospect pit at site 4 (fig. 8.1). A, Faulted upper Pleistocene or lower Holocene deposit (younger) overlies buried soil on faulted middle Pleistocene(?) deposit (older). $B$, Closeup shows fractures in buried soil. Laminar $\mathrm{CaCO}_{3}$ layer at top of photograph. Secondary $\mathrm{CaCO}_{3}$ outlines fracture to right of hammer.

\section{Faults in Bedrock Units}

Bedrock may have been offset during late Pleistocene or Holocene time at site 5 (fig. 8.1) on a splay of the rangefront fault. In one prospect pit (fig. 8.5), a Tertiary dike emplaced in Paleozoic limestone is sheared and brecciated, and has slickensides along its contact with the limestone at the base of the exposure. Near the ground surface, the limestone and dike rocks are separated by about $1 \mathrm{~m}$ of colluvium with vertically oriented clasts. Some of these clasts are petrocalcic fragments; secondary $\mathrm{CaCO}_{3}$ occurs on the tops and sides of other clasts reworked from older soils. This wedge may represent material that fell into an open fracture formed by fault movement along the limestone-dike contact; similar wedges were observed in fractures along recent faults caused by the Borah Peak earthquake (K.L. Pierce, oral 
commun., 1985; Crone and others, 1985). The soil formed on the colluvial wedge has a thin, sandy A horizon, a weakly oxidized $\mathrm{B}$ horizon, and little pedogenic $\mathrm{CaCO}_{3}$, suggesting that the colluvium was deposited in early Holocene time.

A second prospect pit at site 5 exposes the dike in contact with a younger Pleistocene deposit. The soil on this deposit is similar in $\mathrm{CaCO}_{3}$ development to the buried soil at site 4 , but has less pedogenic silica; the soil at site 5 is similar to soils formed on 40-50-ka deposits in Fortymile Wash (unit Q2a, Taylor, 1985). The deposit in the prospect pit contains a near-vertical zone of secondary $\mathrm{CaCO}_{3}$ that is separated from but parallels the alluvium-dike contact, and slickensides occur on the plates of $\mathrm{CaCO}_{3}$. These relations suggest that two movements of the fault occurred here after deposition of the alluvium.

\section{SUMMARY}

The Bare Mountain range-front fault and the associated northern fault complex have been active in Quaternary time. Relations in prospect pits and linear features on aerial

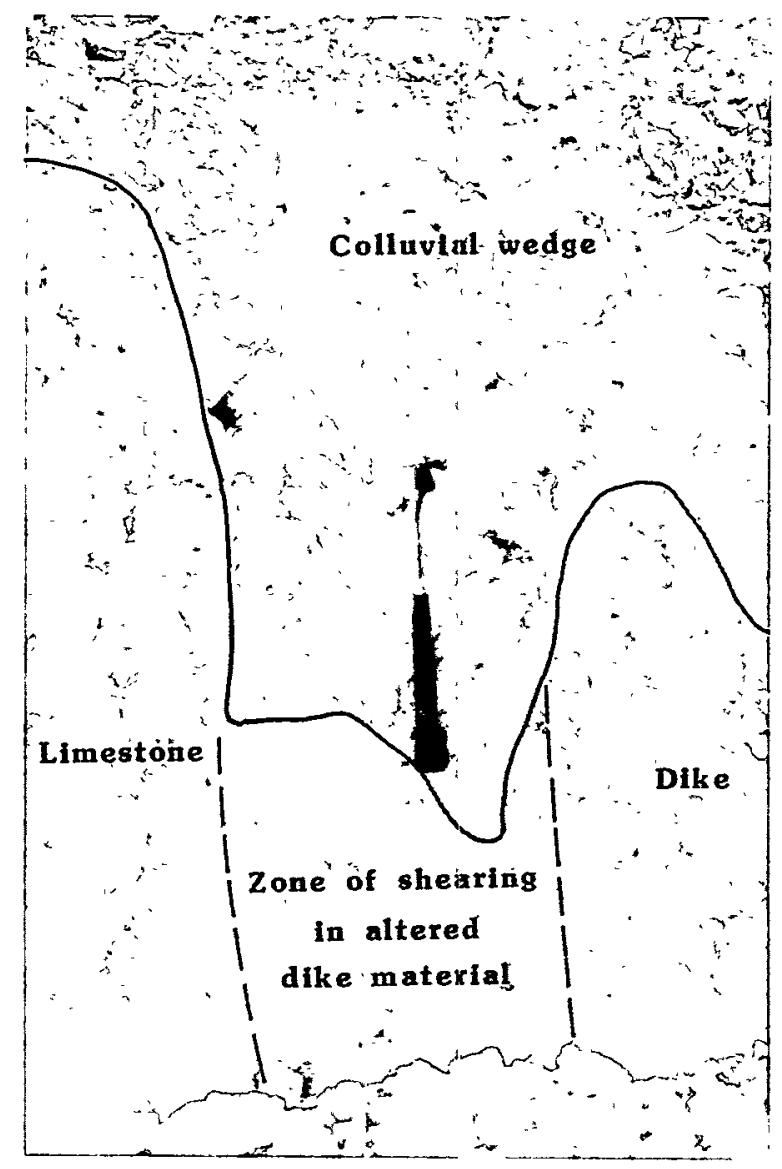

Figure 8.5. North wall of prospect pit at site 5 (fig. 8.1). Faulted limestone-dike contact with probable Holocene colluvial wedge filling formerly open fracture. photographs suggest that late Pleistocene or Holocene faulting has occurred along two segments (fig. 8.1): (1) from site 4 to $1 \mathrm{~km}$ north of site 3 , and (2) from about $2 \mathrm{~km}$ south of Chuckwalla Canyon to Tarantula Canyon. Between the two segments and south of site 4, the range-front fault probably last moved in middle or late Pleistocene time.

Recurrent movement has occurred on the range-front fault and the northern fault complex. Two episodes of faulting have occurred since the late Pleistocene at site 4 (fig. 8.4), and are indicated at site 5 (fig. 8.5). Recurrent faulting is also demonstrated at numerous locations by slickensides preserved on secondary $\mathrm{CaCO}_{3}$ and silica in fault zones (fig. 8.2).

Tertiary and lower Pleistocene(?) deposits are complexly faulted north of the Tarantula Canyon drainage (fig. 8.1), but none of the faults appear to extend upward into Holocene deposits, and few middle and upper Pleistocene(?) fans are faulted. These relations suggest that this area is relatively inactive. The fault complex appears to stop near the Tarantula Canyon drainage, but this may be due to burial by younger Pleistocene fans that extend from this drainage south.

The north-northeastward trend of the northern fault complex roughly parallels the line of Pleistocene cinder cones in Crater Flat (fig. 8.1). In addition, the two active segments of the range-front fault trend north or north-northeast, as do long drainage segments in Crater Flat. This local trend is similar to a regional trend of recent tectonic features noted by Carr (1984), and suggests structural control of the Crater Flat drainages.

\section{REFERENCES CITED}

Bull, W.B., 1964, Geomorphology of segmented alluvial fans in western Fresno County, California: U.S. Geological Survey Professional Paper 352-E, p. E89-E129.

Carr, W.J., 1984, Regional structural setting of Yucca Mountain, southwestern Nevada, and late Cenozoic rates of tectonic activity in part of the southwestern Great Basin, Nevada and California: U.S. Geological Survey Open-File Report 84-854, $109 \mathrm{p}$.

Cornwall, H.R., and Kleinhampl, F.J., 1961, Geology of the Bare Mountain quadrangle, Nevada: U.S. Geological Survey Geologic Quadrangle Map GQ-157, scale 1:62,500.

Crone, A.J., Pierce, K.L., and Hait, M.H., Jr., 1985, The Borah Peak earthquake of October 28, 1983: Surface faulting, mass movements, and Quaternary tectonic setting of the Lost River Range: Geological Society of America Field Trip Guide, 1985 Rocky Mountain Section Meeting, Boise, Idaho, 44 p.

Harden, J.W., 1982, A quantitative index of soil development from field descriptions: Examples from a chronosequence in central California: Geoderma, v. 28, p. 1-28.

Harden, J.W., and Taylor, E.M., 1983, A quantitative comparison of soil development in four climatic regimes: Quaternary Research, v. 20, p. 342-359. 
Hoover, D.L., Swadley, W C, and Gordon, A.J., 1981, Correlation characteristics of surficial deposits with a description of surficial stratigraphy in the Nevada Test Site region: U.S. Geological Survey Open-File Report 81-512, 27 p.

Rogers, A.M., Harmsen, S.C., Carr, W.J., and Spence, W., 1983, Southern Great Basin seismological data report for 1981 and preliminary data analysis: U.S. Geological Survey Open-File Report 83-669, 240 p.

Sowers, J.M., 1985, Pedogenic calcretes of the Kyle Canyon alluvial fan, southern Nevada: Morphology and development: Berkeley, University of California, Ph.D. thesis, 159 p.
Swadley, W C, Hoover, D.L., and Rosholt, J.N., 1984, Preliminary report on late Cenozoic faulting and stratigraphy in the vicinity of Yucca Mountain, Nye County, Nevada: U.S. Geological Survey Open-File Report 84-788, 42 p.

Taylor, E.M., 1985, Paleoclimatic interpretations of the geomorphology and Quaternary soils in the Yucca Mountain area of the Nevada Test Site: Boulder, University of Colorado, M.S. thesis, $217 \mathrm{p}$.

Wallace, R.E., 1977, Profiles and ages of young fault scarps, northcentral Nevada: Geological Society of America Bulletin, v. 88, p. $1267-1281$. 


\title{
9. Reinterpretation of the Beatty Scarp, Nye County, Nevada
}

\author{
By W C Swadley, James C. Yount, and Samuel T. Harding
}

\section{CONTENTS}

\author{
Abstract 113 \\ Introduction 113 \\ Previous work 113 \\ Geologic setting 113 \\ Stratigraphy $\mathbf{1 1 5}$ \\ Methods and observations $\mathbf{1 1 6}$ \\ Mapping 116 \\ Scarp profiles 116 \\ Trenching 116 \\ Age determinations $\mathbf{1 1 8}$ \\ Seismic-refraction profiles $\mathbf{1 1 8}$ \\ MINI-SOSIE profile 119 \\ Conclusions 119 \\ References cited 119
}

\section{Abstract}

A prominent $10-\mathrm{km}$-long topographic scarp near Beatty, Nevada, heretofore considered a Quaternary fault scarp by previous workers, is interpreted to be the product of fluvial erosion. The discontinuous west-facing scarp ranges in height from $30 \mathrm{~m}$ to less than $2 \mathrm{~m}$. An investigation of the scarp that included surficial mapping of the area, logging of two trenches excavated across the scarp, and seismic-reflection and seismicrefraction profiles found no evidence of offset. The trend of the scarp, parallel to the bottom lands of the Amargosa River, and exposures of coarse fluvial deposits of the Amargosa River at or near the base of the scarp indicate that the scarp was formed by lateral erosion by the river.

A ${ }^{14} \mathrm{C}$ age of $10,000 \pm 300 \mathrm{yr}$ on carbonized wood $(W-5673)$ in fluvial deposits at the base of the scarp indicates that the scarp was undercut in early Holocene time. The silt bed containing the carbonized wood was dated at approximately onehalf million years by the empirical uranium-trend dating method. The reason for the difference between these two ages remains unresolved.

\section{INTRODUCTION}

The arcuate Beatty scarp forms a prominent topographic break in slope about $2 \mathrm{~km}$ south of Beatty, Nevada. The scarp, interpreted as a Quaternary fault by previous workers, is within $25 \mathrm{~km}$ of a proposed radioactive waste repository at Yucca Mountain (fig. 9.1). This study was undertaken to evaluate the age and amount of possible
Quaternary offset along the Beatty scarp. The work is part of a larger effort, done in cooperation with the U.S. Department of Energy, Nevada Nuclear Waste Storage Investigations Project, that is meant to evaluate the nature and timing of movement on potentially active faults in the region around Yucca Mountain.

The 10-km-long Beatty scarp trends generally northsouth, approximately parallel to the west edge of Bare Mountain. Most of the scarp is formed in Pleistocene gravel; approximately one-fifth of the length crosses pre-Quaternary rocks. The scarp is discontinuous; crosscutting streams have either eroded the scarp or buried it under alluvial deposits for approximately half of its length.

\section{Previous work}

The arcuate trace of the Beatty scarp, which crosses the border of the Bullfrog and Bare Mountain quadrangles (fig. 9.1), has been mapped and interpreted in various ways. On the west, the geologic map of the Bullfrog quadrangle (Cornwall and Kleinhampl, 1964) shows the central part of the scarp as a Quaternary fault. In the adjacent Bare Mountain quadrangle (Cornwall and Kleinhampl, 1961) the northern part of the scarp was mapped as a fault offsetting rocks of Paleozoic to Quaternary age; the south one-third of the scarp, which is formed entirely in Quaternary deposits, was not mapped as a fault. In a description of the structural setting of the Yucca Mountain region, Carr (1984) interpreted the Beatty scarp as a fault of Quaternary age.

\section{Geologic setting}

The Beatty scarp parallels the bottom lands of the Amargosa River, bordering the west side of Bare Mountain (fig. 9.1). Bare Mountain consists of a triangular area of intensely deformed Late Proterozoic and Paleozoic sedimentary rocks overlain at the north end by upper Tertiary gravel. The Late Proterozoic and Paleozoic rocks have undergone episodes of folding and faulting in the Mesozoic and a period of faulting and intrusion during the Tertiary (Cornwall and Kleinhampl, 1961). The east side of Bare Mountain is bounded by an east-dipping normal fault that has had Quaternary offset (see chapter 8). Along its north edge, Bare Mountain Paleozoic rocks rest in fault contact against deformed Tertiary volcanic flows and tuffs. A complex of Pleistocene 
and Holocene alluvial fans covers the lower slopes of the west flank of Bare Mountain. The Beatty scarp is developed, for the most part, in these alluvial slopes. West of the narrow segment of the bordering Amargosa River valley, a small group of hills expose Paleozoic rocks similar to those of Bare Mountain. The area beyond the south limit of the scarp is largely underlain by alluvial deposits of the Amargosa River floodplain.

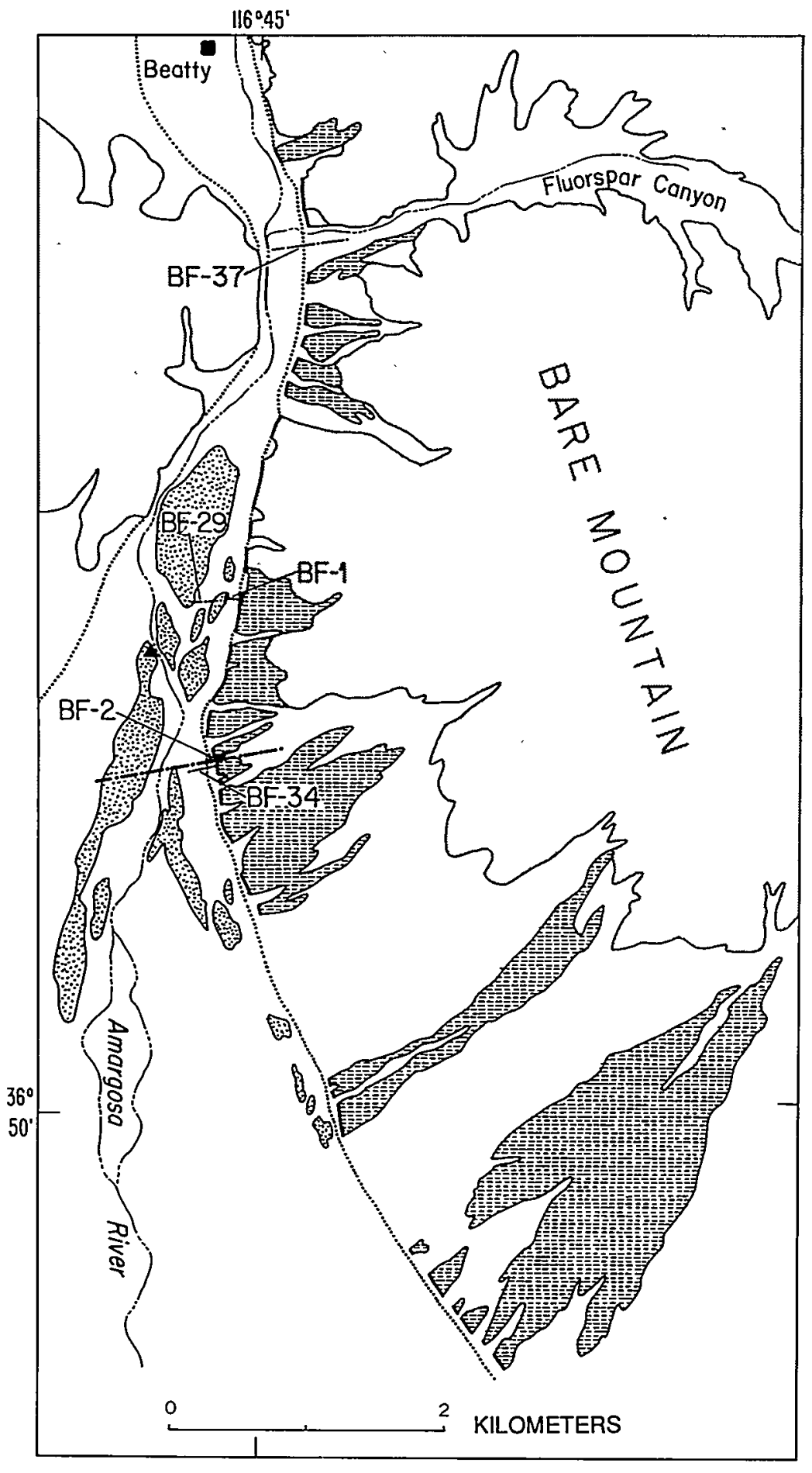

\section{EXPLANATION}

Holocene and upper Pleistocene alluvial deposits (includes units Qla, Qlb, Qlc, Q2b; see table 9.1)

Holocene terrace deposits of Amargosa .... River (unit Qf; see table 9.1)

Pleistocene and Pliocene(?) alluvial fans truncated by Beatty scarp (unils Q2C and QTa, undivided; see table 9.1)

$\square \begin{gathered}\text { Pre-Quaternary rocks (includes Tertiary } \\ \text { volcanic rocks and Paleozoic }\end{gathered}$ bedrock)

$\longrightarrow$ Contact

$\longrightarrow$ Scarp

................. Approximate margin of Amargosa River bottom lands

$\longmapsto$ Trench location

._._._ Seismic refraction profile line

-..- Seismic reflection profile line

- Sample locality of "C date

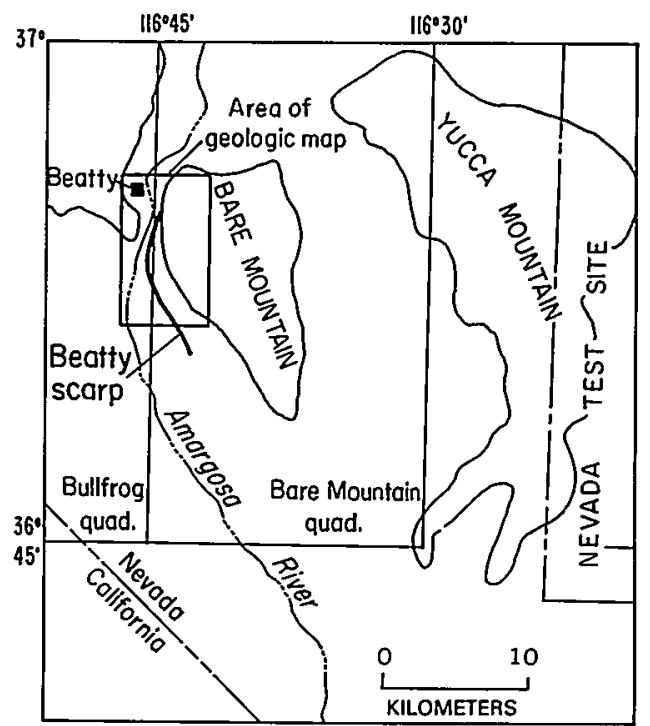

Figure 9.1. Index map and simplified geologic map of Beatty scarp area, Nevada.

114 Geologic and Hydrologic Investigations, Yucca Mountain, Nevada 
Table 9.1. Surficial units exposed along the Beatty scarp and equivalent units in the Nevada Test Site region

[Nevada Test Site (NTS) area modified from Hoover and others (1981, fig. 2)]

\begin{tabular}{|c|c|c|c|}
\hline \multirow[b]{2}{*}{ Age } & \multicolumn{2}{|c|}{ Beatty area } & \multirow{2}{*}{ 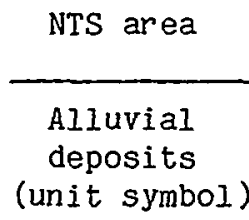 } \\
\hline & $\begin{array}{c}\text { Alluvial } \\
\text { deposits } \\
\text { (unit symbol) }\end{array}$ & $\begin{array}{c}\text { Fluvial } \\
\text { deposits } \\
\text { (unit symbol) }\end{array}$ & \\
\hline Holocene-n & $\begin{array}{l}\text { Q1a } \\
\text { Q1b } \\
\text { Q1c }\end{array}$ & $\begin{array}{l}\text { Qf } \\
Q f \\
Q f\end{array}$ & $\begin{array}{l}\text { Q1a } \\
\text { Q1b } \\
\text { Q1c }\end{array}$ \\
\hline $\begin{array}{l}\text { Late and middle } \\
\text { Pleistocene. }\end{array}$ & $\begin{array}{l}\mathrm{Q} 2 \mathrm{~b} \\
\mathrm{Q} 2 \mathrm{c}\end{array}$ & --- & $\begin{array}{l}\text { Q2a } \\
\text { Q2b } \\
\text { Q2c }\end{array}$ \\
\hline $\begin{array}{l}\text { Early Pleistocene } \\
\text { and Pliocene(?). }\end{array}$ & QTa & -- & QTa \\
\hline
\end{tabular}

\section{Stratigraphy}

Quaternary surficial deposits exposed along the Beatty scarp have been divided into seven map units (table 9.1). Six of these units consist of alluvial deposits of local streams; the seventh consists of fluvial deposits of the Amargosa River. The lithology of the six alluvial units and the correlation characteristics used in their mapping in the area of the Nevada Test Site (NTS) have been described by Hoover and others (1981) and are described here only briefly (table 9.1). The fluvial unit was not described by Hoover and others (1981).

Units Q1a, Q1b, and Q1c (in order of increasing age) form channel deposits, two levels of low terraces, and alluvial fans of the modern drainage system. These units consist chiefly of locally derived unconsolidated gravel, sand, and silt. Deposits are typically moderately sorted to unsorted, well-bedded to nonbedded, sandy pebble to boulder gravel with lesser amounts of silty, gravelly sand. A Holocene age has been inferred for units Q1a, Q1b, and Q1c on the basis of their weak soil development and on correlations with similar deposits in adjacent areas (table 9.1). Only unit Q1c exhibits recognizable amounts of pedogenic carbonate (stage I carbonate morphology of Gile and others, 1966).

Units Q2b and Q2c form alluvial fans and terrace remnants that are commonly topographically above units Q1a, Q1b, and (or) Q1c in nearby locations, but are locally overlain by these younger units. Units $Q 2 b$ and $Q 2 c$ consist of slightly to moderately well consolidated gravel, sandy gravel, and gravelly sand. They are typically poorly to moderately well bedded, moderately well sorted to unsorted, and consist of angular to subrounded, locally derived clasts as much as $0.5 \mathrm{~m}$ across. Minimum ages of $160 \mathrm{ka}$ and $270 \mathrm{ka}$ have been inferred for units Q2b and Q2c, respectively, based on uranium-trend ages determined for soils developed at the surface of similar units in the NTS area (Swadley and others, 1984).

Unit QTa is composed of nonbedded, poorly sorted gravel that is slightly to moderately well cemented with secondary carbonate minerals and occurs as dissected alluvial fans and fan remnants. Fans of unit QTa in the area of the Beatty scarp commonly are overlain by thin gravel deposits of unit Q2c. An age of less than $2 \mathrm{Ma}$ and greater than $0.8 \mathrm{Ma}$ is suggested for unit QTa by radiometric ages of ash beds in deposits that are stratigraphically below and above unit QTa in the NTS area (Swadley and others, 1984).

The fluvial unit, Qf, consists of interbedded gravel, gravelly sand, sand, and silt deposited by the Amargosa River. The deposits vary from unconsolidated to slightly consolidated, poorly bedded to moderately well bedded, and poorly to well sorted. The gravel consists of subrounded to well-rounded clasts of Tertiary basalt and rhyolitic welded tuff and Paleozoic quartzite and carbonate rocks. Unit Qf forms channel deposits and three levels of terrace deposits along the Amargosa River valley. A sample of carbonized wood fragments from a cutbank exposure of the lowest terrace deposit of unit Qf (fig. 9.1) has been dated by the ${ }^{14} \mathrm{C}$ method at 9,800 \pm 300 yr (W-5676; Meyer Rubin, written commun., 1985). The degree of soil development in the highest terrace deposits of unit Qf in the area of the Beatty scarp is interpreted as indicating that unit $Q f$ may also be late Pleistocene age in part. 


\section{METHODS AND OBSERVATIONS}

Study of the Beatty scarp involved mapping of surficial deposits in the area of the scarp, measurement of scarp profiles, excavation and logging of two trenches, dating by radiometric methods, measurement of shallow seismic profiles with a high-resolution refraction system, and measurement of one deeper seismic profile with the MINISOSIE system.

\section{Mapping}

The scarp consists of a 10-km-long line of isolated scarp segments. Most of these segments occur in lower and middle Pleistocene alluvial fan gravels (fig. 9.1). Approximately $2 \mathrm{~km}$ of the northern part of the scarp cuts across Paleozoic sedimentary rocks and Tertiary volcanic rocks. The scarp is preserved for about 45 percent of its overall length. The missing segments of the scarp either have been eroded by intermittent crosscutting streams that drain westward from Bare Mountain, or have been buried by alluvial fans deposited by these streams.

Quaternary deposits truncated by the scarp consist of alluvial fans of units QTa and Q2c. The youngest of these deposits, unit Q2c, has been correlated by use of mapping criteria with deposits at NTS for which a minimum age of about $270 \mathrm{ka}$ has been inferred, based on several age determinations by the uranium-trend method (Rosholt and others, 1985). The oldest deposits that extend across the trace of the scarp without being cut by it are alluvial fans of unit Q1c. This unit has not been dated but is considered to be early Holocene based on the weak soil development (Hoover and others, 1981).

Mapping revealed no exposures of units Q2c or QTa, the truncated units, on what would be the downthrown side of the scarp. It did show, however, a discontinuous line of fluvial deposits of the Amargosa River, unit Qf, that parallels the scarp to the west for much of its length (fig. 9.1). These deposits include boulders as much as a meter in diameter. From the proximity of these deposits to the scarp and from the size of clasts in these deposits, we infer that at one time a major channel of the Amargosa River closely followed the scarp.

\section{Scarp Profiles}

Twenty-five scarp profiles were measured by the method described by Wallace (1977). All profiles were measured across the central and northern parts of the scarp in areas where it is formed in Quaternary deposits. The maximum scarp height measured was $30 \mathrm{~m}$ near the midpoint of the scarp. Scarp height decreases northward to about $9 \mathrm{~m}$ at the north end of the scarp and southward to less than $2 \mathrm{~m}$ at the southernmost exposure. Slope angles of the scarp range from about $35^{\circ}$ where the scarp is highest, to about $20^{\circ}$ at a scarp height of $4 \mathrm{~m}$. Profiles were smooth and sigmoidal, with no knicks or perturbations indicative of multiple scarpforming events.

Wallace (1977, p. 1273) presented a series of histograms of the principal slope angles for groups of young fault scarps in north-central Nevada that range in age from historical to considerably older than $12,000 \mathrm{yr}$. A histogram of the principal slope angles of the Beatty scarp profiles (fig. 9.2) most closely resembles fault scarps in the Humbolt Range less than $12,000 \mathrm{yr}$, but more than a few thousand years in age (Wallace, 1977, p. 1273, fig. 8).

\section{Trenching}

Two trenches were excavated by bulldozer to examine the evidence for faulting along the Beatty scarp (fig. 9.1). Trench BF-1 (fig. 9.3) was sited near the midpoint of the scarp in order to expose the maximum scarp height in Quaternary deposits. Excavation of the trench was begun on the lower slope of the scarp several meters east of the scarp toe at a location where colluvial gravel mantles bedrock and alluvial fan gravel (units $\mathrm{Pzb}$ and QTa) that form most of the scarp at this site. The trench was excavated normal to the scarp for about $35 \mathrm{~m}$ to the west. The bulldozer excavated to a depth of $3.5 \mathrm{~m}$; both trench walls were logged with the aid of a 1-m square rope grid. Trench BF-1 exposed interbedded fluvial gravel, sand, and silt (unit Qf) overlain by pebbly silt (unit Q1c) that interfingers with colluvial gravel (Q1c) at the toe of the scarp (fig. 9.3). The contact between units Qf and Q1c is a slight disconformity. No soil is developed at this contact, and no soils are preserved within

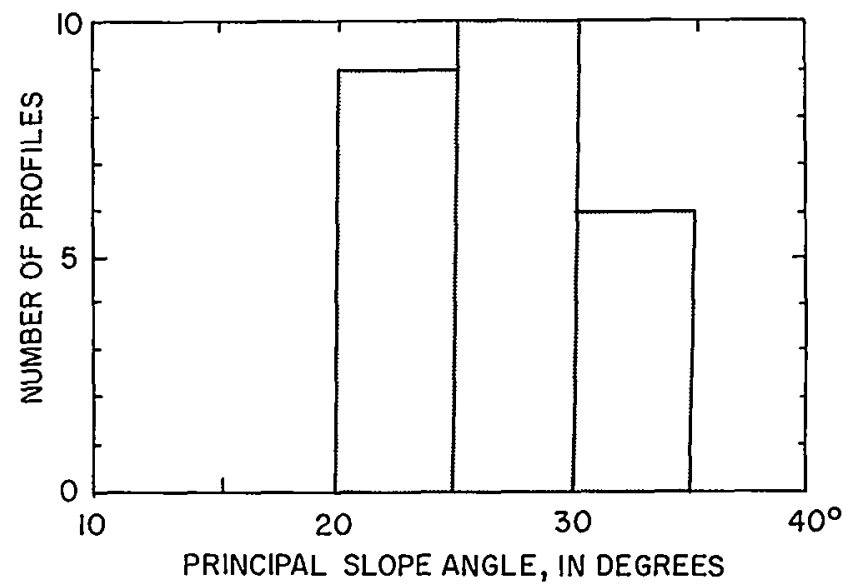

Figure 9.2. Histogram of principal slope angles of scarp profiles of Beatty scarp.

116 Geologic and Hydrologic Investigations, Yucca Mountain, Nevada 
unit Qf. Paleozoic bedrock was exposed at the east end of the trench. No evidence of offset or disturbed strata was found in any of the units exposed in the trench.

At this site, the Beatty scarp shows no stratigraphic offset and is most readily explained as an erosional scarp formed by lateral migration and undercutting by the Amargosa River. Deposition of the fluvial sediments at the base of the scarp occurred contemporaneously with the formation of the scarp. Eastward planation by the river was probably stopped when the river encountered the bedrock that is exposed at the east end of the trench.

Trench BF-2, sited $2 \mathrm{~km}$ south of BF-1 (fig. 9.1), exposes part of an alluvial fan (unit Q1c) that extends across the projection of the scarp without apparent offset. The trench is located about $15 \mathrm{~m}$ south of an older alluvial fan (unit Q2c) that is truncated by the scarp. Excavation and logging of the trench followed procedures similar to those at BF-1. Carbonate-cemented gravel (unit QTa) exposed in the south wall and in the floor of the trench unconformably underlies alluvial gravel of unit Q1c (fig. 9.4). Unit QTa disappears near the point where the projection of the scarp intersects the trench wall. The upper contact of unit QTa, as well as its western termination of exposure, appear eroded. No fault planes can be recognized that offset stratigraphy in the trench; one near-vertical zone of clast disruption exposed in the north wall near the projection of the scarp trace, overlies a thin gravel bed that is not offset. An equivalent zone of disturbed fabric was not present in the south wall.

The interpretation of the trench is that the truncation of unit QTa and the adjacent fan deposit of unit Q2c is erosional. However, truncation by faulting and subsequent erosion of the faulted edge of unit QTa prior to deposition of the overlying unit, unit Q1c, cannot be ruled out at this exposure. The zone of disturbed fabric in unit Q1c is not thought to be the result of faulting because the underlying strata are not disturbed.

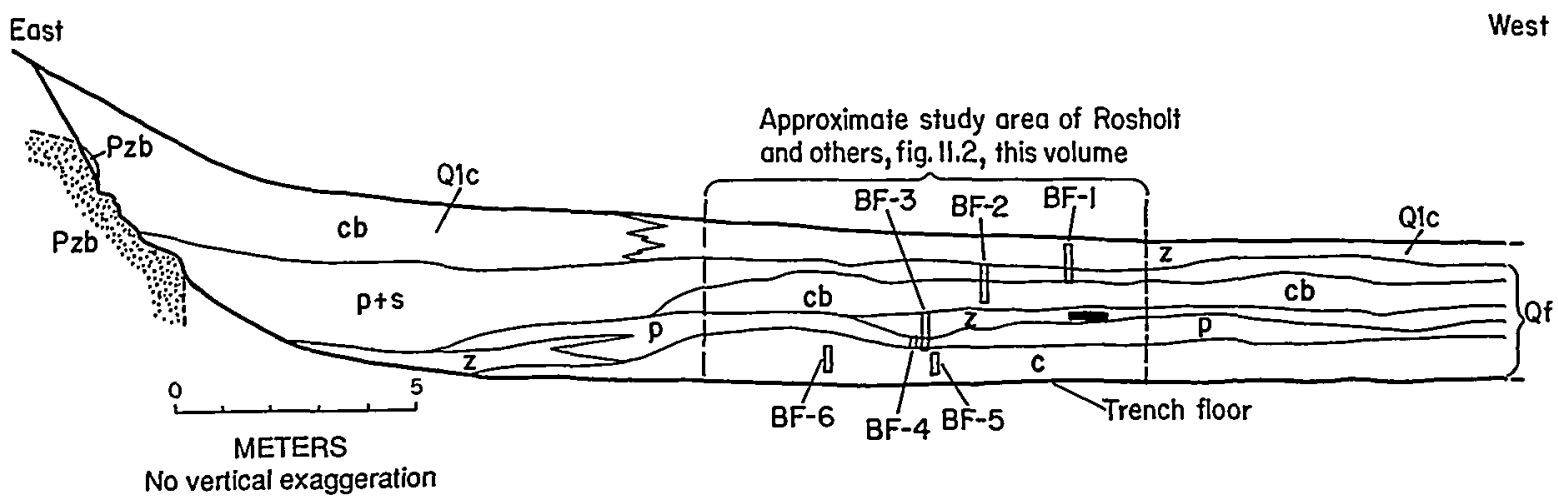

Figure 9.3. Sketch of part of south wall of trench BF-1 (fig. 9.1). Trench exposes fluvial gravel, sand, and silt (unit Qi) overlain by silt and colluvial gravel (unit Q1c). Paleozoic bedrock (unit Pzb) is exposed at east end of trench. Lithology symbols: c, cobble gravel; cb, cobble-boulder gravel; p, pebble gravel; s, sand; $z$, silt. Location of lens of carbonaceous silt containing carbonized wood shown by heavy horizontal line. Labeled vertical bars indicate location of samples dated by uranium-trend method (see table 9.2).

East

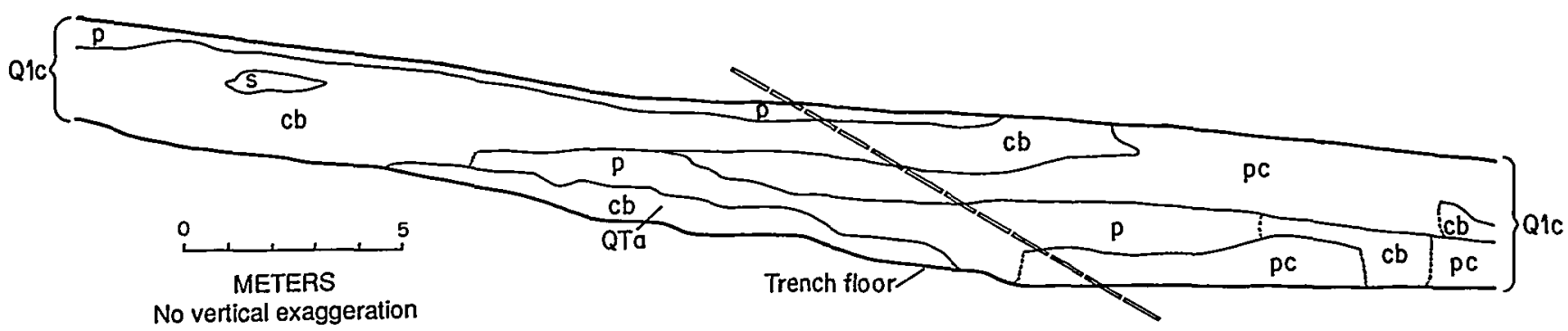

Figure 9.4. Sketch of part of south wall of trench BF-2 (fig. 9.1). Trench exposes carbonate-cemented cobble-boulder gravel (unit QTa) overlain by alluvial fan deposits (unit Q1c). Lithology symbols: $p$, pebble gravel; pc, pebble-cobble gravel; cb, cobble- boulder gravel; s, sand. Dotted contact indicates lateral gradational change in lithology. Dashed line indicates approximate intersection of trench wall with projection of nearby scarp. 


\section{Age Determinations}

Radiometric dating meant to establish the age of the Beatty scarp has given conflicting data. Carbonized wood fragments from a silt bed exposed in trench BF-1 (fig. 9.3) gave an age of $10,000 \pm 300 \mathrm{yr}$ by the ${ }^{14} \mathrm{C}$ method (W-5673; Meyer Rubin, written commun., 1985). Six sets of samples from localities shown on figure 9.3 and a sample collected near trench $\mathrm{BF}-2$ were dated by the experimental uraniumtrend method (table 9.2).

The wood fragments that gave a ${ }^{14} \mathrm{C}$ age of about $10 \mathrm{ka}$ came from the same stratum as uranium-trend sample BF-3 (fig. 9.3), which yielded an age of $480 \mathrm{ka}$. The reason for this considerable difference between data from the two dating methods remains unresolved. The ${ }^{14} \mathrm{C}$ age indicated for carbonized wood from unit $\mathrm{Qf}$ is similar to that obtained for charcoal from the same stratigraphic unit in a cutbank exposure along the Amargosa River about $1 \mathrm{~km}$ southwest of trench BF-1 (W-5676, 9,800 $300 \mathrm{yr}$ ). The uraniumtrend age of approximately $70 \mathrm{ka}$ for unit $\mathrm{Q} 2 \mathrm{c}$ conflicts with those from trench $\mathrm{BF}-1$ in that it infers that the fan composed of unit Q2c truncated by the scarp is younger than post-scarp deposits of unit Qf exposed in trench $\mathrm{BF}-1$. Further sampling has been carried out to resolve these age discrepancies.

\section{Seismic-Refraction Profiles}

Shallow seismic-refraction investigations were carried out at three sites along the Beatty scarp (fig. 9.1). The refraction system, utilizing a sledge-hammer energy source, was capable of detecting refracting horizons within $20 \mathrm{~m}$ of the ground surface (see Rodriguez and Yount, chapter 12). First arrival times read directly from the refracting waveform were plotted against distance from geophone to source (fig. 9.5). The resultant traveltime plots show no steps in the traveltime plots indicative of faulting in the upper $20 \mathrm{~m}$ of alluvium at any of the three sites investigated.

Line BF-29 was located approximately $50 \mathrm{~m}$ south of trench BF-2 and was oriented parallel to the trench (fig. 9.1). The projection of the Beatty scarp indicated on figure 9.4 would cross line BF-29 at approximately its midpoint. Line $\mathrm{BF}-29$ shows evidence of nearly $3 \mathrm{~m}$ of young alluvium (units Q1a?, Q1b?, or Q1c?) overlying alluvium possibly belonging to units Q2b, Q2c, or QTa on a westward sloping contact (see Rodriguez and Yount, chapter 12, for discussion of $P$-wave refraction velocity and its relation to deposit age). No significant displacement of any refracting horizon is evident on the traveltime plot for line BF-29 (fig. 9.5).

Line BF-34 was located approximately $50 \mathrm{~m}$ south of trench $\mathrm{BF}-1$ with an east-west trend (fig. 9.1). The east end of line BF-34 corresponds with the west end of the trench. Because no evidence of faulting was found at the base of the Beatty scarp in trench BF-1, the possibility existed that the Amargosa River had eroded the scarp back to the east from
Table 9.2. Uranium-trend ages of samples [Rosholt and others (chapter 11) describe sampling and dating method used for these samples]

\begin{tabular}{|c|c|c|}
\hline Laboratory & No. & Age (ka) \\
\hline \multicolumn{3}{|c|}{ Trench $B F-1$} \\
\hline BE1 & & $75 \pm 15$ \\
\hline $\mathrm{BF} 2$ & & $155 \pm 35$ \\
\hline $\mathrm{BF} 3$ & & $480 \pm 50$ \\
\hline $\mathrm{BF} 4$ & & $530 \pm 70$ \\
\hline BF5 & & $540 \pm 100$ \\
\hline BF6 & & $460 \pm 90$ \\
\hline \multicolumn{3}{|c|}{ Near BF-2 } \\
\hline $\mathrm{BT} 2 \mathrm{~F}$ & & $70 \pm 12$ \\
\hline
\end{tabular}
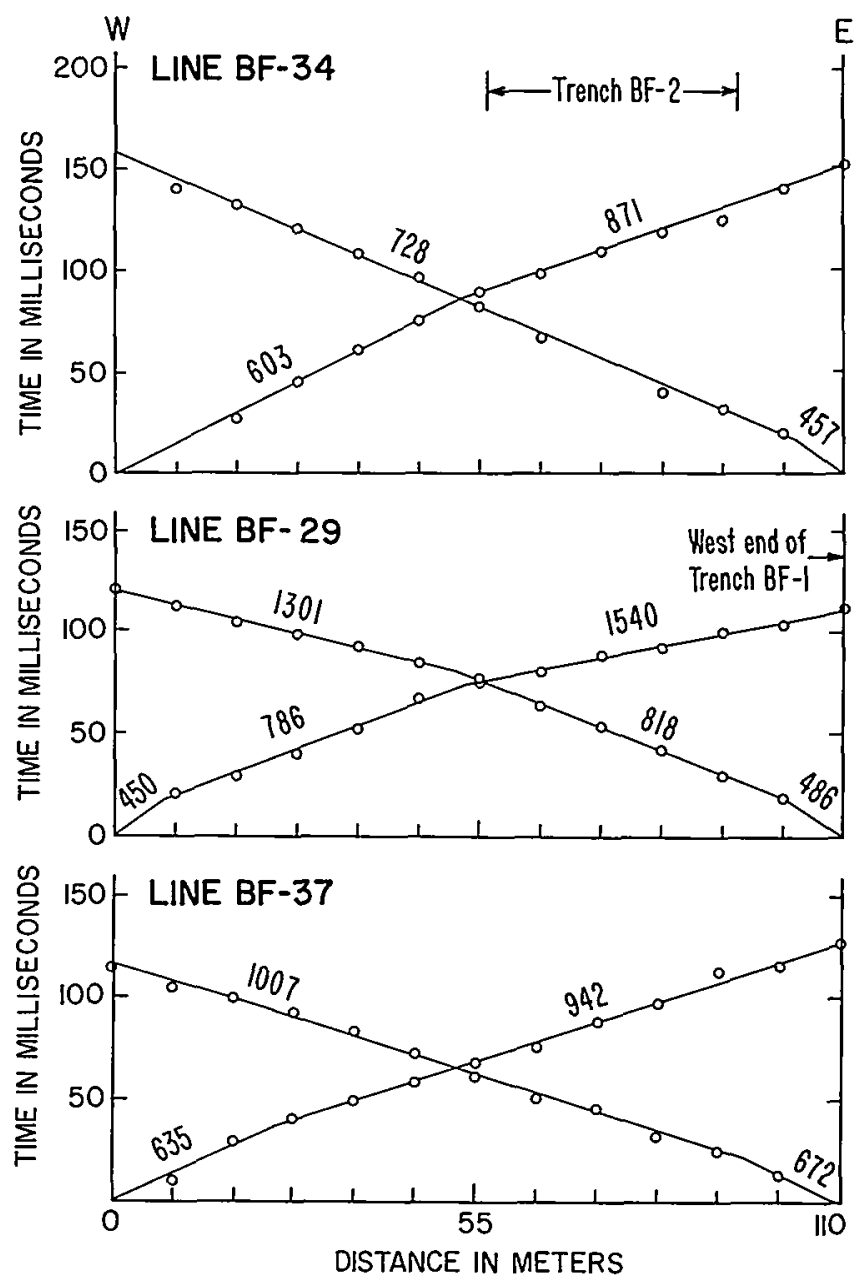

Figure 9.5. Traveltime plots for shallow refraction lines across or near Beatty scarp. Line BF-37 from Fluorspar Canyon; Line $B F-34$ south of trench BF-2; Line BF-29 south of trench BF-1. Refraction velocity for each segment of plot shown in meters per second. Circles indicate actual first arrival time at each geophone. See figure 9.1 for location of lines. 
some more westerly postion. Line BF-34 shows no evidence of offset refractors for some $110 \mathrm{~m}$ to the west of trench BF-1 (fig. 9.5). Instead, approximately $2 \mathrm{~m}$ of alluvium belonging to units Q1a, Q1b, or Q1c appears to horizontally overlie a sequence of deposits that have refraction velocities similar to those of units Q2a, Q2b, Q2c, and QTa.

Line BF-37 was located across the projection of the Beatty scarp at Fluorspar Canyon (fig. 9.1). The line was sited on an alluvial fan composed of unit $\mathrm{Q} 1 \mathrm{c}$ where this fan crosses a segment of the scarp that developed in alluvium of unit Q2c. The refraction line trends east-west and is centered on the projection of the scarp across Fluorspar Canyon. No evidence of offset refractors can be seen from the traveltime plot (fig. 9.5) at this locale. Rather, $3 \mathrm{~m}$ of alluvium of unit $\mathrm{Q} 1 \mathrm{c}$ appears to overlie alluvium of unit Q2c along a slightly east dipping contact.

\section{MINI-SOSIE Profile}

The MINI-SOSIE (MS) system is a small, versatile high-resolution seismic-reflection technique that uses vibrating earth tampers as energy sources. Reflection data are acquired by an array of geophones along the line of the profile as a series of vibration points are occupied. The system and the computer processing of the data are discussed by Wiles (1979). Using the MS technique, a seismicreflection profile was measured across the Beatty scarp (Harding, chapter 10) adjacent to trench BF-2 (fig. 9.1). Two reflection horizons were detected within, what is here interpreted to be buried Paleozoic bedrock, at depths of about 200 and $300 \mathrm{~m}$. No fault corresponding to the apparent offset of the scarp was indicated.

\section{CONCLUSIONS}

The Beatty scarp formed as an erosional scarp produced by lateral migration of the Amargosa River. This interpretation is based on the trend and location of margins of the bottom lands occupied by the river in late Quaternary time, the occurrence of fluvial deposits at or near the base of the scarp, the lack of conclusive evidence of faulting revealed by surficial mapping and trenching, and the lack of offset of subsurface horizons as shown by seismic-refraction and seismic-reflection profiles.
The age of the scarp is inferred to be early Holocene from the ${ }^{14} \mathrm{C}$ age of carbonized wood in fluvial deposits at the base of the scarp and a very tentative age correlation based on scarp profile data. The difference between this age and the middle Pleistocene age indicated by some of the uraniumtrend age data remains unresolved. Also unresolved is the conflict between the 70-ka age indicated for deposits of unit Q2c truncated by the scarp and ages of approximately $500 \mathrm{ka}$ indicated for fluvial sediments about the same age as the scarp that are exposed at the base of the scarp in trench BF-1.

\section{REFERENCES CITED}

Carr, W.J. 1984, Regional structural setting of Yucca Mountain, southwestern Nevada, and late Cenozoic rates of tectonic activity in part of the southwestern Great Basin, Nevada and California: U.S. Geological Survey Open-File Report 84-854, $109 \mathrm{p}$.

Cornwall, H.R., and Kleinhampl, F.J., 1961, Geology of the Bare Mountain quadrangle, Nevada: U.S. Geological Survey Geologic Quadrangle Map GQ-157, scale 1:62,500.

1964, Geology of the Bullfrog quadrangle and ore deposits related to Bullfrog Hills caldera, Nye County, Nevada and Inyo County, California: U.S. Geological Survey Professional Paper 454-J, $25 \mathrm{p}$.

Gile, L.H., Peterson, F.F., and Grossman, R.B., 1966, Morphological and genetic sequences of carbonate accumulations in desert soils: Soil Science, v. 101, no. 5, 347-360.

Hoover, D.L., Swadley, W C, and Gordon, A.J., 1981, Correlation characteristics of surficial deposits with a description of surficial stratigraphy in the Nevada Test Site region: U.S. Geological Survey Open-File Report 81-512, 27 p.

Rosholt, J.N., Bush, C.A., Carr, W.J., Hoover, D.L., Swadley, W C, and Dooley, J.R., Jr., 1985, Uranium-trend dating of Quaternary deposits in the Nevada Test Site area, Nevada and California: U.S. Geological Survey Open-File Report 85-540, $72 \mathrm{p}$.

Swadley, W C, Hoover, D.L., and Rosholt, J.N., 1984, Preliminary report on late Cenozoic faulting and stratigraphy in the vicinity of Yucca Mountain, Nye County, Nevada: U.S. Geological Survey Open-File Report 84-788, 42 p.

Wallace, R.E., 1977, Profiles and ages of young fault scarps, northcentral Nevada: Geological Society of America Bulletin, v. 88, p. 1267-1281.

Wiles, C.J., 1979, MINI-SOSIE: New concept in high resolution seismic surveys: Oil and Gas Journal, v. 77, p. 94-97. 



\title{
10. Preliminary Results of High-Resolution Seismic-Reflection Surveys Conducted Across the Beatty and Crater Flat Fault Scarps, Nevada
}

\author{
By Samuel T. Harding
}

\section{CONTENTS}

\author{
Abstract 121 \\ Introduction 121 \\ Acknowledgments 121 \\ The MINI-SOSIE system 121 \\ Processing 122 \\ Results and interpretation 122 \\ Beatty scarp 122 \\ Crater Flat fault scarp 123
}

References cited 127

\section{Acknowledgments}

Robert Bucknam and Anthony Crone proposed the two locations as sites whose characteristics could best serve the purposes of our study. Reviews and suggestions for improvement of the manuscript were done by Kathleen M. Haller and Ruth Ann Dwyer. I thank Ted Barnhard, Anthony Crone, Richard Dart, Kathy Haller, Danny Miller, John Michael, Susan Plymell, Kirstin Rinehart, Dave Worley, and Annette Yuan for their many hours in the hot sun during the acquisition of the data. Ruth Ann Dwyer's many suggestions in the data processing aspect were invaluable.

Abstract

Two high-resolution seismic-reflection surveys were conducted across two scarps near Beatty, Nev. Employing the MINI-SOSIE high-resolution seismic-reflection technique, the first survey was run across the a scarp mapped as the Beatty fault about $6 \mathrm{~km}$ south of the town of Beatty. Reflection profiles from this site indicated no evidence of faulting that could be correlated with the scarp. The other survey was located across a prominent down-to-the-west fault scarp on the east side of Crater Flat approximately $26 \mathrm{~km}$ southeast of Beatty. The resulting profile had one distinct reflector that could be carried along the length of the section. We interpreted this reflector to be complexly faulted. A major, nearly vertical fault was projected to the surface fault scarp. This fault appeared on a reflector at $160 \mathrm{~m}$ depth and was located east of the fault scarp. This fault, if associated with the scarp, represents a strike-slip fault. Evidence for normal faulting that could be associated with the fault scarp could not be seen from the collected data.

\section{INTRODUCTION}

Two high-resolution seismic-reflection surveys were conducted southeast of Beatty, Nev., in an effort to determine if the MINI-SOSIE (MS) source system could be used to delineate near-surface faulting in surface alluvium and volcanic rocks. This equipment has led to a better understanding of fault-scarp mechanics. Locations of the survey sites are shown on figure 10.1.

\section{THE MINI-SOSIE SYSTEM}

The MINI-SOSIE (MS) system is a small, versatile, high-resolution reflection technique that uses earth tampers as energy sources. The foot of each tamper is fitted with a source sensor that identifies a time break for each impact of the foot. Time breaks for the impacts are transmitted to a recording truck by radio. The tampers have a peak energy input at about $45 \mathrm{~Hz}$ but they also supply higher frequency energy above $100 \mathrm{~Hz}$ (Wiles, 1979) that improves the resolution of shallow reflections.

Time breaks from the tampers are crosscorrelated in the field with the signals received by the geophones. The crosscorrelated data are electronically stored while data from succeeding impulses are crosscorrelated. Vibration-point spacing is $18.8 \mathrm{~m}$. For each vibration point, a sufficient amount of crosscorrelated data are stacked and autocorrelated to yield a good signal-to-noise ratio.

The MS technique has several distinct advantages over conventional reflection-profiling methods. Because of its small size, the system can be easily transported into remote areas. The system is also capable of collecting reflection data in seismically noisy areas, a useful feature when working in urban areas. Where ambient seismic noise is a problem, the number of impacts stacked for each vibration point can be increased until the reflected signal can be distinguished from the undesirable noise. Another advantage of the MS 
system is that it can be operated in populated areas without the threat of inducing ground motion that could damage nearby structures. Thus, the MS can fill gaps in conventional seismic reflection data associated with areas of cultural development. By employing specific source and receiver arrays, destructive interference from horizontal propagating waves are greatly reduced. Finally, distributing 1,500-2,000 impacts over the entire group interval yields a distinct advantage over single explosive sources.

\section{Processing}

Field data from the Beatty scarp and Crater Flat fault scarp were processed by specialized computer techniques at the U.S. Geological Survey facilities in Denver. Processing steps included tape reformat and gain recovery, commondepth-point (CDP) sort, constant-velocity analyses (CVA), normal-moveout correction, spectral whitening, deconvolution, bandpass filtering, datum and residual statics, final CDP stack migation, and depth conversion. The resulting migrated time sections consisted of $1 \mathrm{~s}$ (two-way traveltime) of 12-fold CDP data. The time sections were then converted to depth (km) sections.

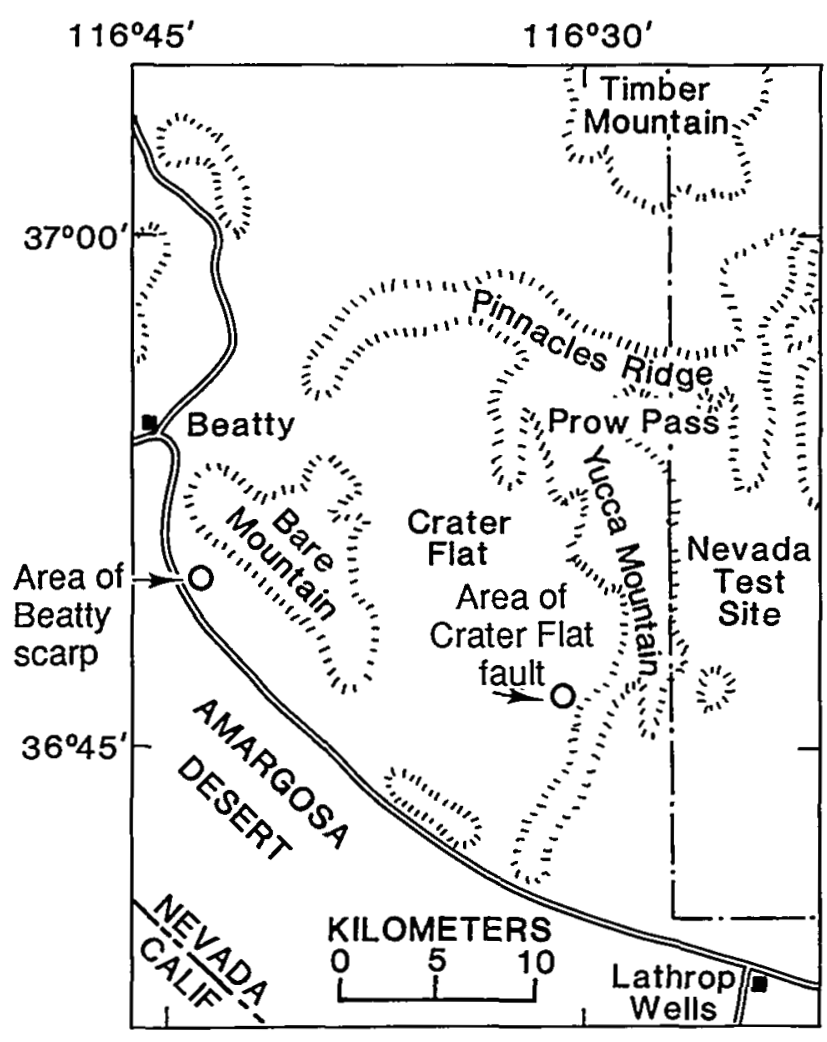

Figure 10.1. Location map of survey areas southeast of Beatty, Nevada. Circles indicate general locations of seismic-reflection surveys. Hachures enclose areas of relatively higher relief. (Modified from Swadley and Hoover, 1983.)

\section{RESULTS AND INTERPRETATION}

\section{Beatty Scarp}

The location of the 1,123-m seismic line that crosses the Beatty scarp is shown in figure 10.2. The scarp corresponds to CDP 226 and the highway to CDP 246.

The seismic-reflection time section that was obtained from the field data and the same time section after migration are shown in figure 10.3 and 10.4, respectively. The poor quality of the record section probably reflects the small changes in the acoustic impedance contrast between geologic boundaries in addition to severe residual static problems and near-surface scattering of source impulses by boulders. The stacking velocities used are listed in table 10.1. The profile shows two coherent bands of reflections: one at at about $0.260 \mathrm{~s}$, reflector $\mathrm{A}$, and the other at approximently $0.350 \mathrm{~s}$, reflector B. Reflector A is flat or had a slight westward dip, and reflector B has an eastward dip at least to CDP 290, where it becomes somewhat disrupted and appears to turn over and dip west. The depth conversion of the time section is shown in figure 10.5. The depths are measured in kilometers from a datum of $1.2 \mathrm{~km}$ above sea level.

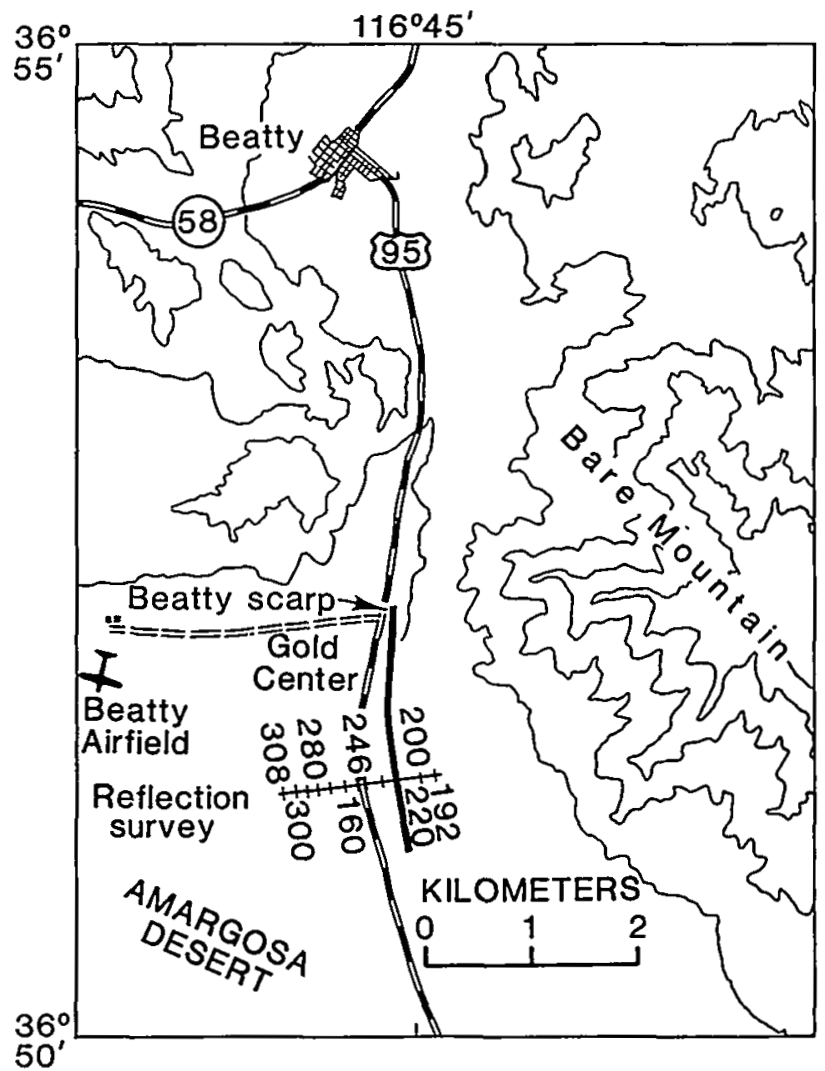

Figure 10.2. Location of seismic-reflection survey south of Beatty, Nevada. General scarp location is shown in relation to reflection survey. Numbers along reflection survey line are common-depth-point (CDP), as shown on figures 10.3, 10.4, and 10.5 . 
The coherency of reflector B (fig. 10.4) makes it impossible to project a fault from the surface scarp to depth. One possibility is to project it through reflector B at CDP 280. This may represent a fault plane with a dip of approximately $30^{\circ}$ to the west. The apparent motion, determined by reflector $B$, would be down to the east, the reverse downto-the-west motion, indicated if the scarp were a fault. Therefore, in my opinion the Beatty scarp is not fault related.

\section{Crater Flat Fault Scarp}

A seismic reflection survey was conducted in Crater Flat (fig. 10.6) located between and parallel to trenches 2 and 3 (Swadley and Hoover, 1983). The line was $1,219 \mathrm{~m}$ long and extended east $468 \mathrm{~m}$ from the trace of the fault in the trenches and extended west of the fault $750 \mathrm{~m}$. The time section is shown in figure 10.7 , the migrated time section is shown in figure 10.8, and the depth converted section is shown in figure 10.9 .

The near-surface velocity structure was found to be complex along this profile. A discussion of the processing steps utilized to determine this structure is in order. The original brute stacks, using a constant velocity across the line, showed practically no coherent energy. Constant velocity analyses (CVA) were then run on 20 adjacent CDP's. Velocities from $1,500 \mathrm{~m} / \mathrm{s}$ to $3,000 \mathrm{~m} / \mathrm{s}$ were run by increasing the constant velocity by $100 \mathrm{~m} / \mathrm{s}$ for each panel. The next 10 CDP's were dropped, and the same procedure was then repeated on the next 20 adjacent CDP's. The entire section was treated in this manner. The next step was to again stack the data and look for further trends in coherent energy. A number of residual static windows were run using the velocity analyses on coherent bands of energy found on the velocity stack. These usually were only short bursts of coherent energy over a few CDP's, but they were enough to determine the general velocity structure. It was found that the sloping interface at $0.100 \mathrm{~s}$ from $\mathrm{CDP} 320$, dipping eastward, to $0.190 \mathrm{~s}$ at CDP 190 (fig. 10.7), reflector A, appeared when the residual static window was run across part of the section from 0.50 to $0.300 \mathrm{~s}$. The residual static operator was then determined from this interface using this dip to define the window. The constant-velocity profiles were then run using this horizon to make the residual static correction. This procedure was repeated to improve (1) the stacking velocities and (2) the coherent reflections. When the signal-to-noise

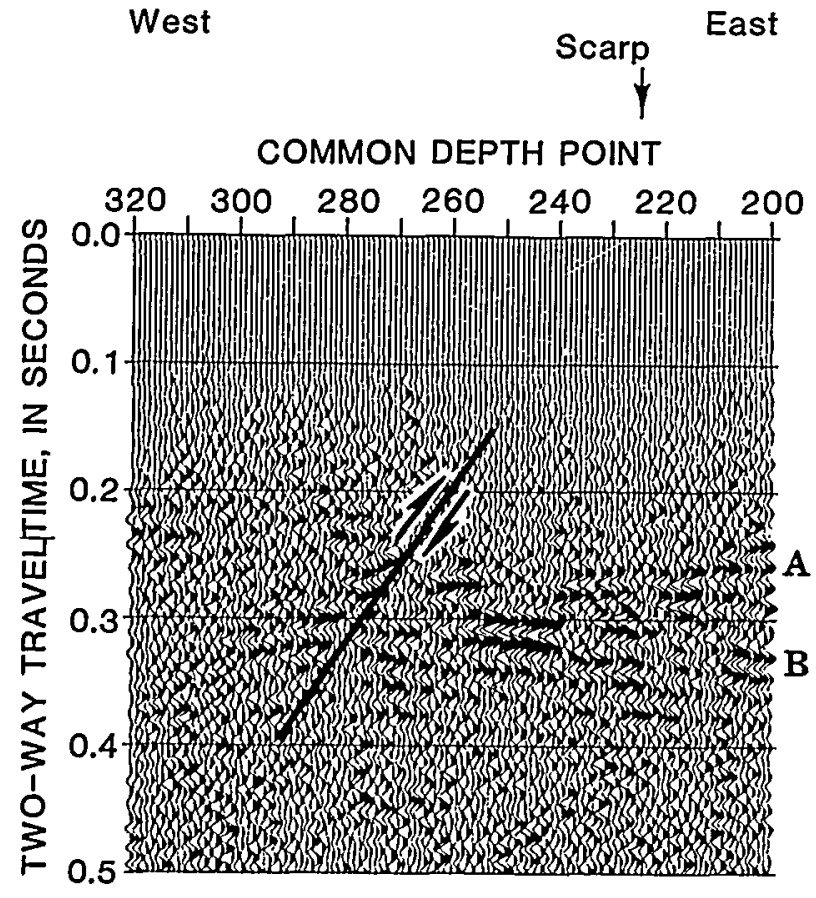

Figure 10.3. Computer plot of unmigrated seismic-reflection section, Beatty scarp, Nevada. Datum is at $1,200 \mathrm{~m}$ above sea level and time section is corrected at $1,500 \mathrm{~m} / \mathrm{s}$. Reflections $A$ and $B$ are bands of coherent reflected energy returns. The formation they arise from is unknown due to lack of well control in the area. The line represents $1,123 \mathrm{~m}$ of subsurface coverage. Surface position of common-depth-point numbers shown on figure 10.2 .

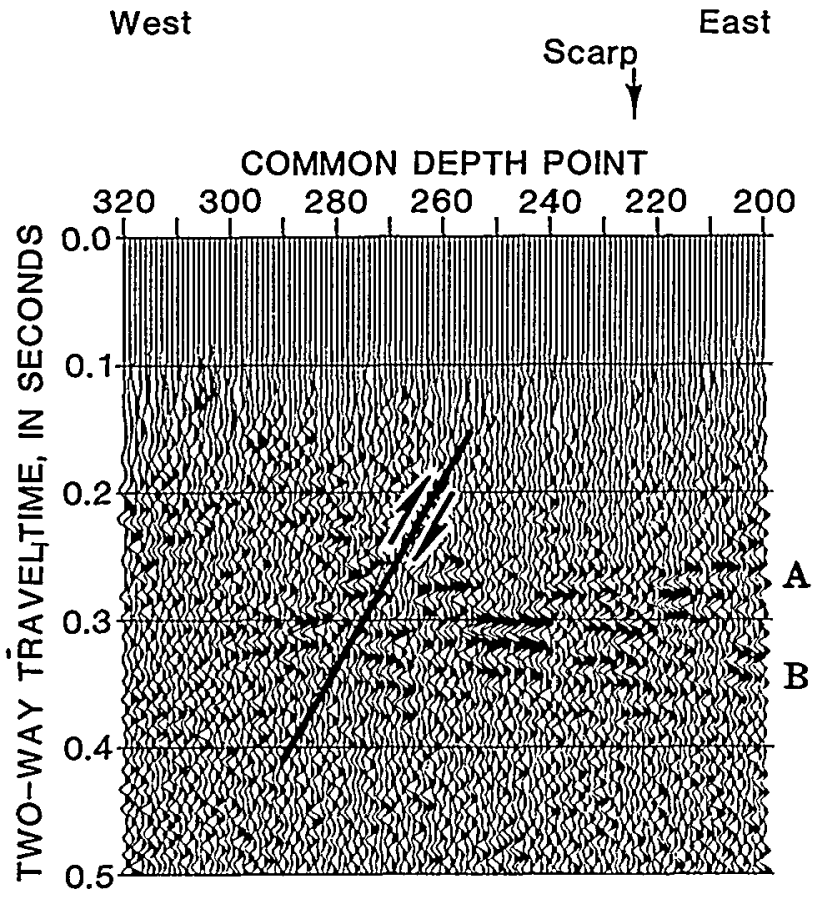

Figure 10.4. Computer plot of migrated seismic-reflection section, Beatty scarp, Nevada. Datum is at $1,200 \mathrm{~m}$ above sea level and time section corrected at $1,500 \mathrm{~m} / \mathrm{s}$. Reflections A and $B$ are bands of coherent reflected energy returns. The formations they arise from are unknown due to lack of well control in the area. The line represents $1,123 \mathrm{~m}$ of subsurface coverage. Surface positions of common-depth-point numbers shown on figure 10.2. 
Table 10.1. Stacking velocities for common depth points, Beatty scarp, Nevada

\begin{tabular}{lcc}
\hline $\begin{array}{l}\text { Common } \\
\text { depth } \\
\text { point }\end{array}$ & $\begin{array}{c}\text { Traveltime } \\
(\mathrm{s})\end{array}$ & $\begin{array}{c}\text { Velocity } \\
\text { (m/s) }\end{array}$ \\
\hline 210 & 0.130 & 2,344 \\
& .280 & 2,500 \\
& .600 & 3,125 \\
& 1.000 & 3,425 \\
220 & .100 & 2,500 \\
& .200 & 2,969 \\
& .600 & 3,281 \\
& 1.000 & 3,438 \\
270 & .100 & 2,500 \\
& .200 & 2,969 \\
& .600 & 3,281 \\
& 1.000 & 3,438 \\
2980 & .100 & 2,500 \\
& .200 & 2,969 \\
& .600 & 3,281 \\
& 1.000 & 3,438 \\
\hline
\end{tabular}

ratio is near a value of 1 , every processing stage must be carefully considered to prevent creating coherent reflections where none exist.

The resulting near-surface velocities varied laterally to a considerable degree. Figure 10.10 shows the isovelocity contours of the root-mean-square velocities determined from the CVA that was used for stacking the data and for converting the time section to depth (fig. 10.9). The depth section (fig. 10.9) did not exhibit the relatively planar, dipping reflector A that was observed on the time section. The lowvelocity wedge from around CDP 230 to CDP 190 (fig. 10.10), was necessary to stack the coherent band of seismic energy (labeled A in figs. 10.7, 10.8, 10.9). The dramatic change between the depth and time sections across this part of the profile was related to the insertion of the low-velocity wedge.

Correlation between the isovelocity plot (fig. 10.10) and the surface geology showed an apparent slowing of the surface velocities across the units mapped as the intermediate and younger fluvial gravels of Quaternary age (see fig. 10.6). Where the line crossed units mapped as the undivided older fluvial gravel deposits and sedimentary rocks unit of Tertiary and Quaternary age, the near-surface velocities were higher. The velocity analysis showed a low-velocity wedge under the Tertiary volcanic rocks unit.

The depth section presented the most visible display of the one reflector that could be traced across the section (reflector A, fig. 10.9). This reflector was relatively flat from CDP 320 to CDP 280 and then dipped eastward to CDP 237, with some minor faulting interpreted as offsetting the reflection. Reflector A was then interpreted to be downfaulted approximately $40 \mathrm{~m}$ at CDP 235 . Reflector A then dipped westward for about 5 CDP's and was faulted to a depth of about $150 \mathrm{~m}$ and appeared to be slightly bowed upward to CDP 200. This line may or may not have intersected the eastern branch of a fault (mapped by Swadley and Hoover, 1983) that was not trenched. This fault appeared to cut the reflector marked B (fig. 10.9) and was the reason for terminating reflector $\mathrm{A}$. This fault also appears to have the same dip as the surface fault.

The complicated faulting shown in the middle part of the cross section was interpreted from faulting seen in trench 2. While the surface expression may not have been representative of the subsurface, activity in the subsurface appears to be related to the scarp. The data indicated the presence of a negative flower structure (Harding, 1985), usually associated with strike-slip faulting. Other examples of this type of seismic reflection signature have been presented by Emmons (1969) and Harding (1985). Our seismic-reflection data from this survey showed no evidence that basinbounding down-to-the-west normal faulting or calderacollapse faulting were the mechanisms for the fault scarp formation.

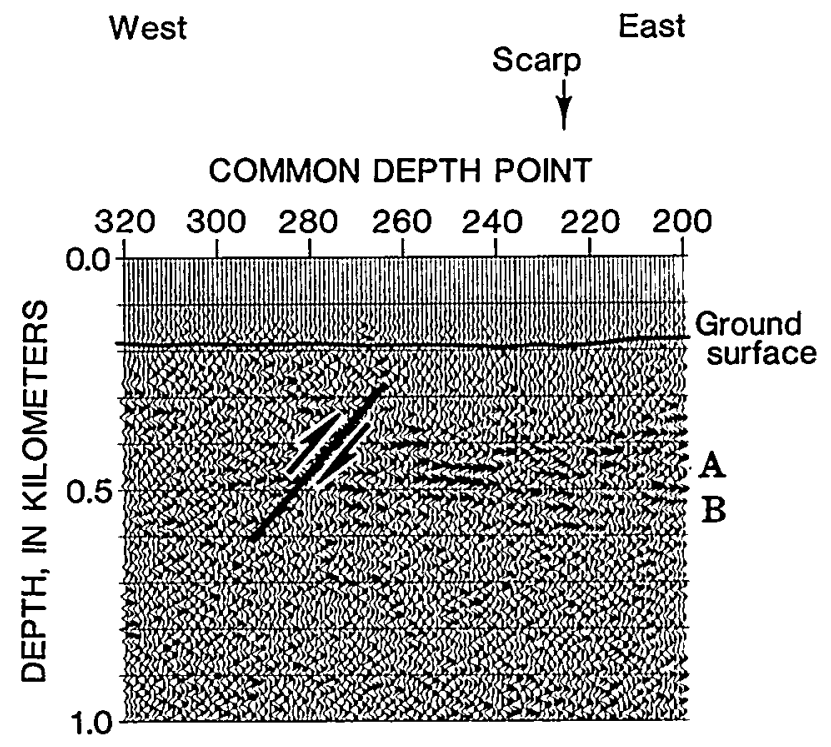

Figure 10.5. Computer plot of migrated depth section, Beatty scarp, Nevada. Datum is at $1.2 \mathrm{~km}$ above sea level. Surface locations of common-depth-point numbers shown on figure 10.2. Vertical exaggeration is 1.09. Reflections $A$ and $B$ same as in figures 10.3 and 10.4 . 


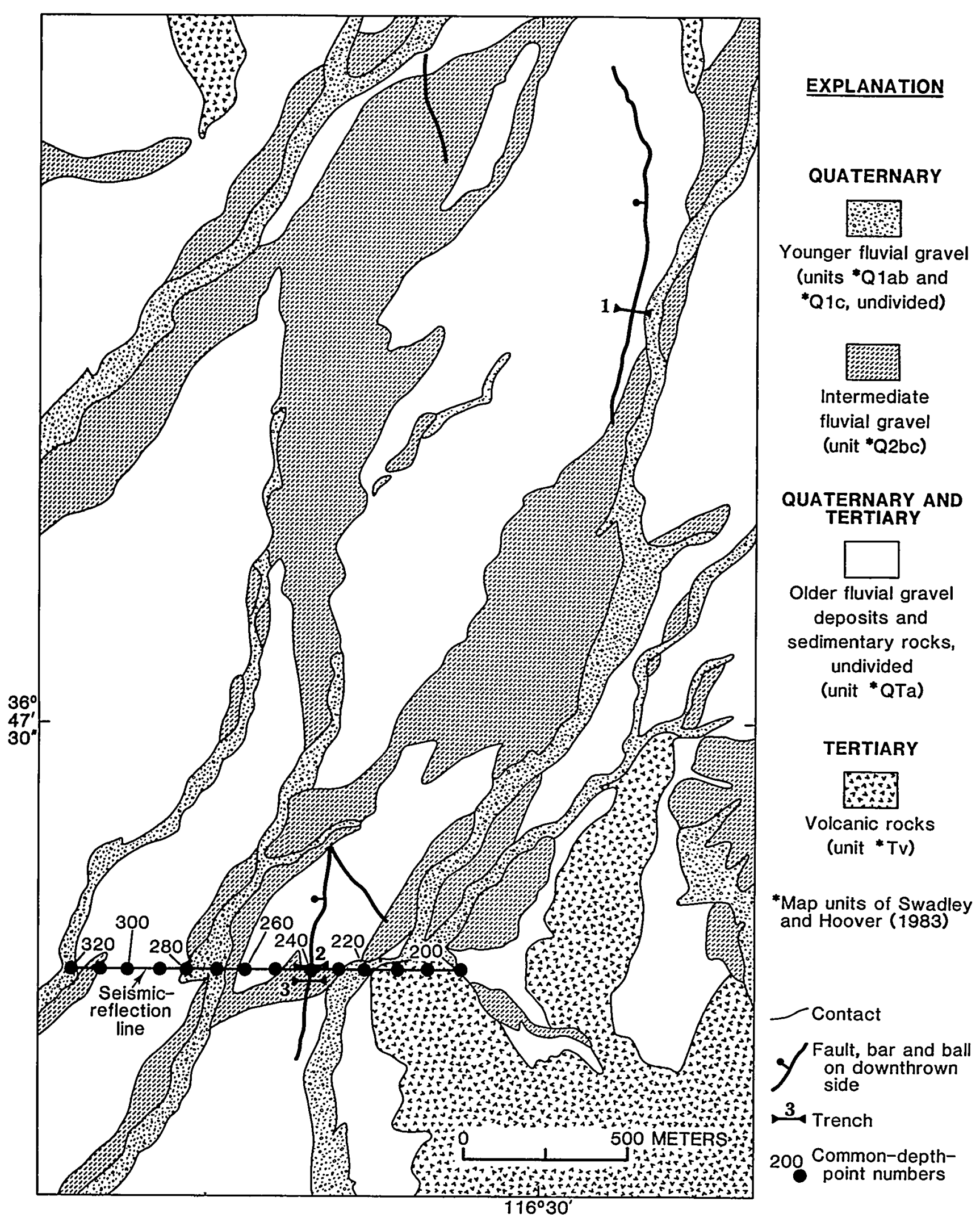

Figure 10.6. Geologic map of southeast Crater Flat, Nevada, showing seismic-reflection line with common-depth-point locations, trench locations, and fault scarps. (Modified from Swadley and Hoover, 1983.) 


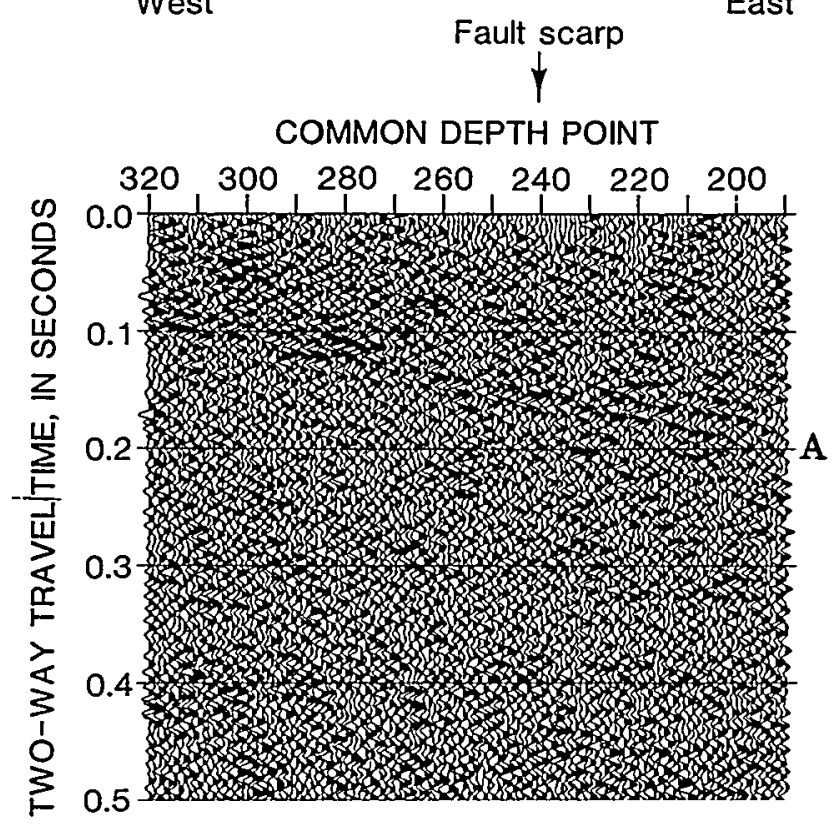

Figure 10.7. Computer plot of unmigrated seismic-reflection section, Crater Flat, Nevada. Reflector A delineates a band of coherent energy. Length of line is $1,219 \mathrm{~m}$ from commondepth-point 190 to 310 . Datum is set at ground surface.

West

East

Fault scarp
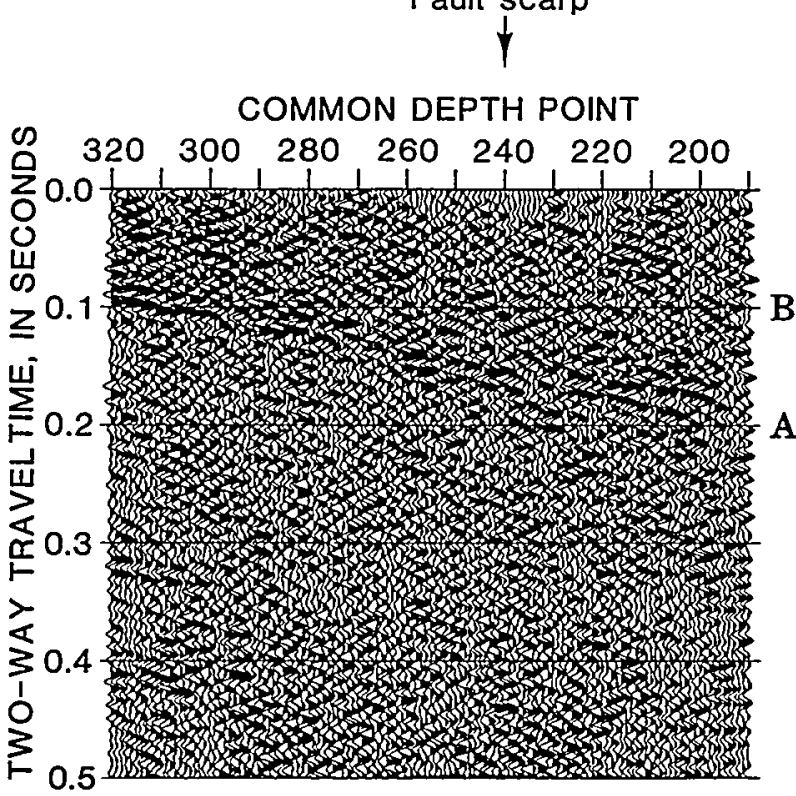

Figure 10.8. Computer plot of migrated seismic-reflection section, Crater Flat, Nevada. Surface locations of commondepth-point numbers shown on figure 10.6. Reflections $A$ and $B$ are bands of coherent reflected energy returns.

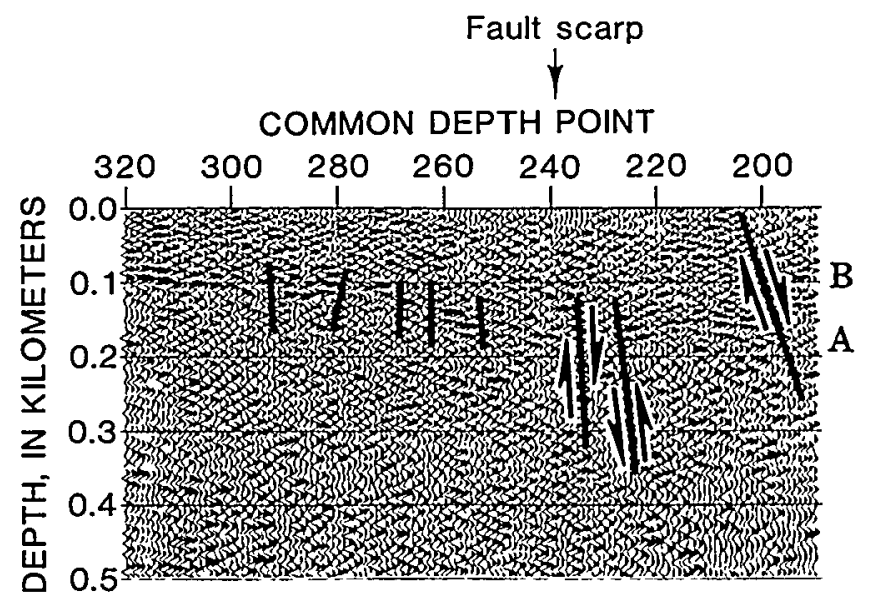

Figure 10.9. Computer plot of migrated depth section, Crater Flat, Nevada. Reflectors A and B same as in figure 10.8. Reflector $A$ has been greatly changed by velocity function used from figure 10.10. Small near-vertical bars indicate minor faults. Larger faults shown with sense-of-motion arrows.

Geologic map-unit symbols

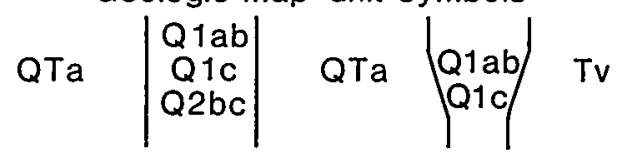

COMMON DEPTH POINT

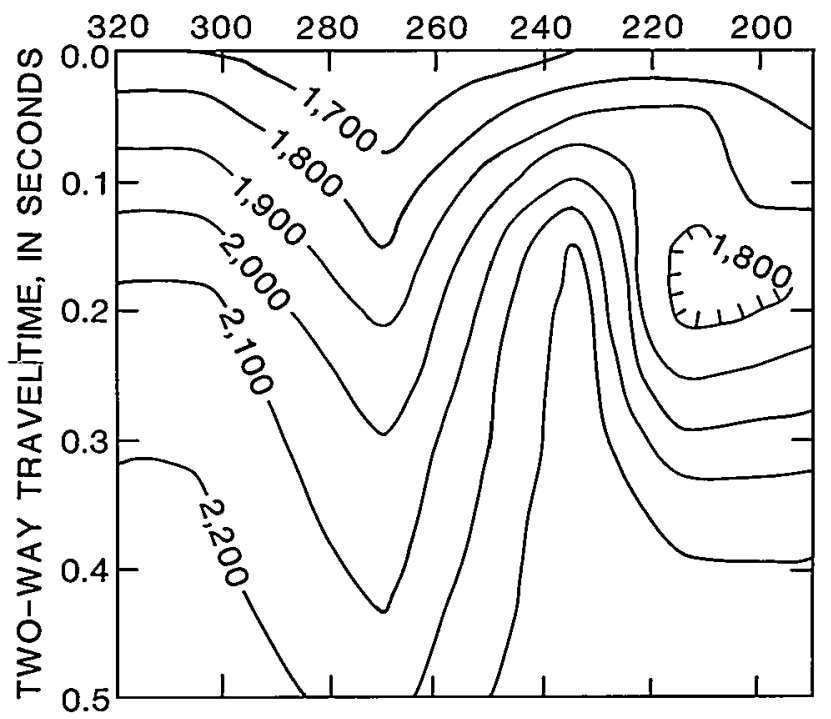

Figure 10.10. Computer plot of isovelocity contours in meters per second of root-mean-square velocities used for stacking velocities and for depth conversion, Crater Flat, Nevada. Geologic map-unit symbols (explained in figure 10.6) indicate surficial geology crossed by seismic-reflection line. 


\section{REFERENCES CITED}

Emmons, R.C., 1969, Strike-slip rupture patterns in sand models: Tectonophysics, v. 7, p. 71-87.

Harding, T.P., 1985, Seismic characteristics and identification of negative flower structures, positive flower structures, and positive structural inversion: American Association of
Petroleum Geologists Bulletin, v. 69 , no. 4, p. 582-600. Swadley, W.C, and Hoover, D.L., 1983, Geology of faults exposed in trenches in Crater Flat, Nye County, Nevada: U.S. Geological Survey Open-File Report 83-608, 15 p.

Wiles, C.J., 1979, MINI-SOSIE: New concept in high resolution seismic surveys: Oil and Gas Journal, v. 77, p. 94-97. 


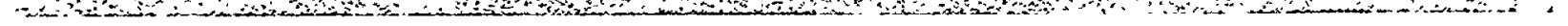




\title{
11. Uranium-Trend Dating of Fluvial and Fan Deposits in the Beatty Area, Nevada
}

\author{
By John N. Rosholt, W C Swadley, and Charles A. Bush
}

\section{CONTENTS}

\author{
Abstract 129 \\ Introduction 129 \\ Acknowledgments 130 \\ Sample collection, preparation, and chemical procedures 131 \\ Sample sites 131 \\ Results 131 \\ Discussion 132 \\ Conclusions 136 \\ References cited 137
}

\section{Abstract}

The uranium-trend dating method is used to estimate the ages of Quaternary deposits to help evaluate the age and origin of a scarp in the Beatty, Nevada, area. For dating deposits of 5 to $800 \mathrm{ka}$ (thousand years) age, the open-system technique consists of determining a linear trend from analyses of six to eight channel samples collected at different depths in a depositional unit. The analytical results plotted as activity ratios of $\left({ }^{238} \mathrm{U}\right.$ $\left.{ }^{230} \mathrm{Th}\right) /{ }^{238} \mathrm{U}$ versus $\left({ }^{234} \mathrm{U}-238 \mathrm{U}\right){ }^{238} \mathrm{U}$ are required for the empirical model. Ideally these data points yield a linear array in which the slope of the line of best fit changes predictably for increasingly older deposits. Analyses of deposits of known age are required to calibrate the empirical model; calibrations were provided by correlations with deposits dated by independent radiometric methods.

A sequence of the fluvial deposits next to the scarp and exposed in trench BF-1 were sampled for dating. An age of $75 \pm 15 \mathrm{ka}$ was obtained for the alluvial unit of sandy silt; an underlying gravel unit indicated an age of $155 \pm 25 \mathrm{ka}$ and an average age of $500 \pm 60 \mathrm{ka}$ was obtained for three different lithologic units in lower silt and gravel deposits. Four suites of samples representing the lower silt and gravel deposits provided the following ages: clayey silt, $480 \pm 50 \mathrm{ka}$; pebble gravel, $530 \pm 70 \mathrm{ka}$; pebble cobble gravels, $540 \pm 100 \mathrm{ka}$ and $460 \pm 90$ ka. For the older units, the dating method does not provide sufficient resolution to distinguish differences in ages for the deposits in the $\mathbf{5 0 0}$ ka group. Disseminated carbonized wood fragments occur in the clayey silt; a radiocarbon age of $10,000 \pm 300 \mathrm{yr}$ for this wood is not consistent with the estimated $480 \mathrm{ka}$ uranium-trend age of the clayey silt host-sediment.

Two separate suites representing the alluvial fan deposit that was truncated by the Beatty scarp adjacent to trench BF-2 also were analyzed; uranium-trend ages of $70 \pm 10$ and $80 \pm 10$ ka were determined on these two suites of samples. Estimates for the time of carbonate accumulation as rinds on pebbles in the same alluvial fan deposit, using the conventional ${ }^{230} \mathrm{Th} /{ }^{234} \mathrm{U}$ method, were $41 \pm 3$ and $68 \pm 4 \mathrm{ka}$.

\section{INTRODUCTION}

Uranium-series disequilibrium dating methods, described by $\mathrm{Ku}$ and others (1979), use conventional closed system ${ }^{230} \mathrm{Th} / 234 \mathrm{U}$ ratios for dating pedogenic carbonates which form rinds on alluvial gravel. These ages provide reasonable estimates of the minimum age of the alluvium. For conventional uranium-series dating (Ku, 1976), a closed system is assumed to exist throughout the history of a sample, which means that there has been no postdepositional migration of ${ }^{238} \mathrm{U}$ or of its daughter products ${ }^{234} \mathrm{U}$ and ${ }^{230} \mathrm{Th}$ ). In contrast, open-system conditions impose no restrictions on migration. Results of other studies of uranium-series disequilibria indicate that uranium commonly exhibits an opensystem behavior in many near-surface deposits (Ivanovich and Harmon, 1982). Because materials suitable for closedsystem dating are commonly absent in Quaternary deposits in this area of the Great Basin, an open-system dating method is needed.

An open-system variation of uranium-series dating called uranium-trend dating has been tested extensively over the past decade. A preliminary model for uranium-trend dating was described by Rosholt (1980) with samples collected from a variety of Quaternary deposits including alluvium, eolian sediments, glacial deposits, and zeolitized volcanic ash. A revised model for uranium-trend systematics was described by Rosholt (1985). The empirical model requires time calibration based on analyses of deposits of known age; results of these calibrations are included in Rosholt and others (1985b). The uranium-trend ages of alluvium, colluvium, and eolian deposits at the Nevada Test Site area were reported by Rosholt and others (1985a).

For uranium-trend dating of sediments, the distribution of uranium-series members during and after sedimentation must have been controlled by open-system behavior. Sediments and soils are penetrated continuously or episodically with water that contains at least small amounts of transported or locally derived uranium. As this water-borne uranium decays, it produces a trail of radioactive daughter products that are readily adsorbed on solid matrix material. If the trail of the daughter products, ${ }^{234} \mathrm{U}$ and ${ }^{230} \mathrm{Th}$, is distributed through the deposit in a consistent pattern, then uranium-trend dating is possible. The large number of 
geochemical variables in an open system precludes the definition of a rigorous mathematical model for uranium migration. Instead, an empirical model is used to define the parameters that can reasonably explain the patterns of isotopic distribution.

This model requires independent time calibration with deposits of known age. None of the known-age deposits used for calibration occur in Nevada; however, results on other deposits in the Nevada Test Site region (Rosholt and others, 1985a) indicate that results obtained by the uranium-trend method are reasonable when compared to geomorphic and stratigraphic relations. In rare instances at NTS, ages can be compared by two methods (Swadley and others, 1984). At Crater Flat, a uranium-trend age of 270,000 years $(270 \pm 30 \mathrm{ka})$ was obtained for gravel deposits of unit $Q 2$ of Swadley and Hoover (1983) that locally overlie and contain reworked cinders from a small volcano northwest of Lathrop Wells, Nev., which has yielded K-Ar ages ranging from 230 to $300 \mathrm{ka}$ as determined by different laboratories (Vaniman and others, 1982).

In an open-system environment, analyses of the abundances of ${ }^{238} \mathrm{U},{ }^{234} \mathrm{U},{ }^{230} \mathrm{Th}$, and ${ }^{232} \mathrm{Th}$ in a single sample do not establish a meaningful time-related pattern of isotopic distribution. However, analyses of several samples, each of which has only slightly different physical properties and only slightly different chemical compositions within a unit, may provide a consistent pattern in the distribution of these isotopes (Rosholt, 1985). Analyses of five to eight samples per unit from several alluvial, colluvial, glacial, and eolian deposits has yielded time-related patterns (Rosholt and others, 1985a, b). These types of deposits range from clay-silt units to gravel units, most of which have isotopic distributions that appear to fit the model.

The purpose of this investigation is to apply the uranium-trend dating technique to the geologic study of surficial deposits along the Beatty scarp in southern Nevada (fig. 11.1). Conventional closed-system uranium-series dating was used to determine the time of carbonate accumulation as rinds on clasts in an alluvial fan truncated by the scarp. The surficial geology of the Beatty scarp site is described by Swadley and others (chapter 9 ).

\section{Acknowledgments}

We thank R.R. Shroba and D.R. Muhs for help collecting samples of the alluvial fan; D.R. Muhs for uranium-series ages and valuable help with interpretation of the age estimates and map illustrations; and N.C. Bostick and E.C. Spiker for the organic petrographic studies of the carbonaceous matter.

Figure 11.1. Generalized geology of Amargosa River area, Nevada, in vicinity of Beatty scarp (from Swadley and others, chapter 9).

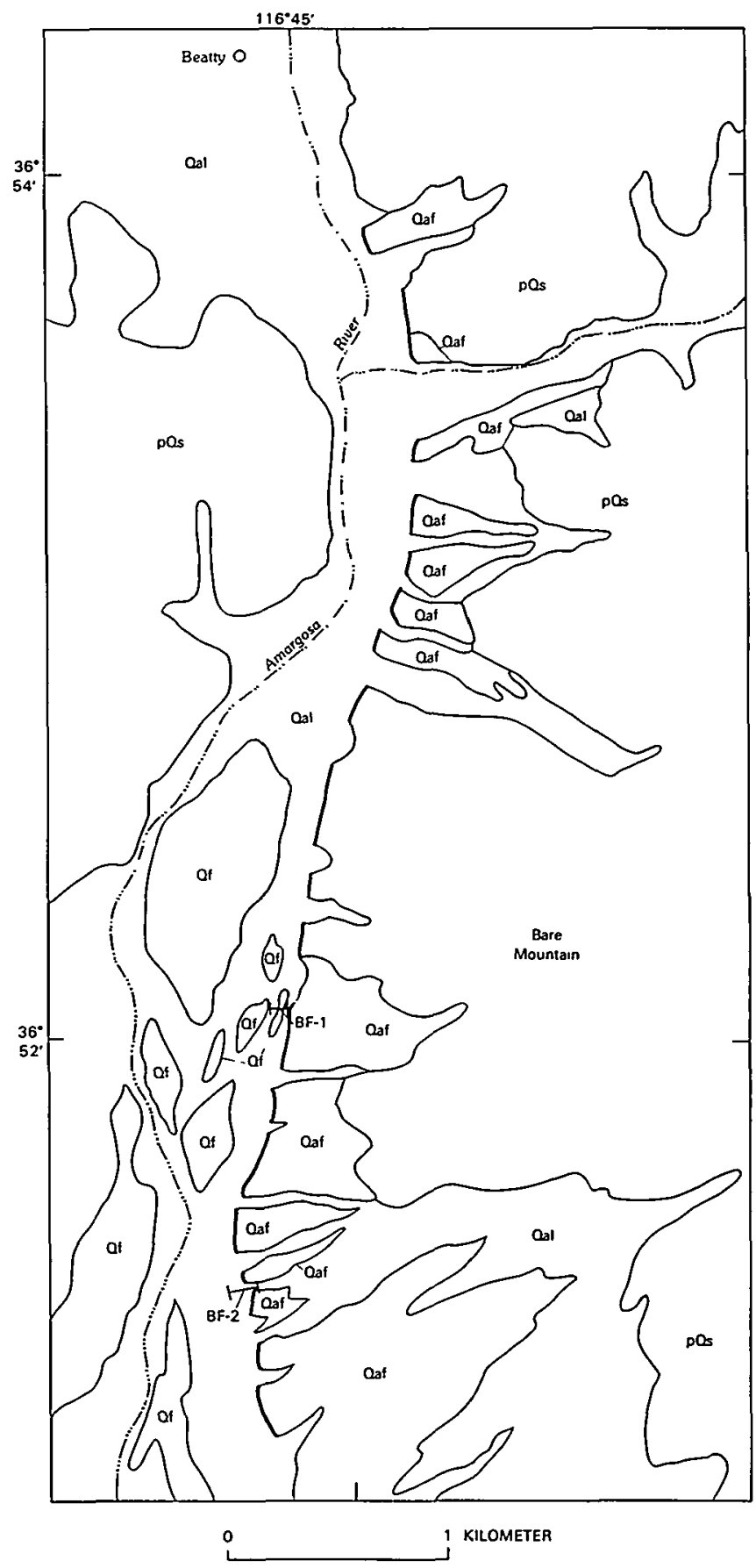

EXPLANATION

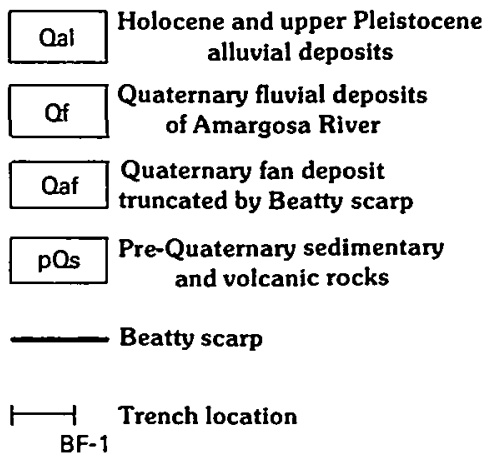




\section{SAMPLE COLLECTION, PREPARATION, AND CHEMICAL PROCEDURES}

Several samples, about $1 \mathrm{~kg}$ each, were collected from a vertical section of each depositional unit. The number of samples required to establish a reliable linear trend in the data depends on the variation in ratios of uranium and thorium that define the trend line; our experience indicates that five to eight samples in a given unit are usually sufficient. It is preferable to collect samples from a channel cut through deposits exposed in a trench wall or a relatively fresh, well-exposed outcrop. Depositional units in the Nevada Test Site area commonly contain abundant pebbles and larger fragments, which are removed by sieving. The remaining less-than-2-mm-size fraction is pulverized to less than $0.2-\mathrm{mm}$ size, homogenized, and retained for analysis. Chemical procedures used for separating uranium and thorium for alpha spectrometry measurements are those described by Rosholt (1985). Spikes of ${ }^{236} \mathrm{U}$ and ${ }^{229} \mathrm{Th}$ are used in the radioisotope-dilution technique to determine the concentrations of uranium and thorium (Rosholt, 1984). For defining uranium-trend slopes, each uranium separate is counted four different times in an alpha spectrometer, and each thorium separate is counted three different times. For conventional closed-system dating using ${ }^{230} \mathrm{Th} /{ }^{234} \mathrm{U}$ ratios, we sampled $\mathrm{CaCO}_{3}$ rinds on the undersides of clasts found in the alluvial fan deposit above trench BF-2. Selective carbonate dissolution procedures followed $\mathrm{Ku}$ and Liang (1984) and chemical procedures followed Rosholt (1984, 1985). Ages were calculated using the isochron-plot method of Szabo and Sterr (1978).

\section{SAMPLE SITES}

Two trenches used in the evaluation of the origin and age of a scarp located near U.S. Highway 95 south of Beatty, are described in detail by Swadley and others (chapter 9); map-unit symbols used for these sites are discussed in there. Complete logs of these two trenches also are available (Swadley and others, 1986).

Trench BF-1 exposed interbedded gravel, sand, sandy silt, and clayey silt (unit Qf) that were deposited by the Amargosa River at the base of the scarp (fig. 11.1). Unit $\mathrm{Qf}$ is overlain by a thin deposit of silty alluvium (unit $\mathrm{Q1c}$ ). Six sample suites, containing approximately eight samples each, were collected from the trench (fig. 11.2). Sample suites BF5 and BF6 are duplicate suites, collected $2.5 \mathrm{~m}$ apart, from the pebble-cobble gravel unit of $Q f$ near the base of the trench.

An alluvial fan (units Q2a, Q2b, Q2c) truncated by the Beatty scarp near trench BF-2, $1.2 \mathrm{~km}$ south of trench BF-1, was sampled at two sites to estimate the age of this fan. Sample suite BT2F was collected from a 1.3-m-deep hole excavated in the exposed side of the fan, approximately $50 \mathrm{~m}$ northwest of the trench. Sample suite 2BT2F was collected from a backhoe pit that penetrated the top of the same alluvial fan surface, approximately $55 \mathrm{~m}$ northwest of the trench. Stones found in the alluvial fan deposit, at 0.5 to $1 \mathrm{~m}$ depth, were sampled to estimate the time of carbonate accumulation in the fan; conventional uranium-series dating was used with analyses of $\mathrm{CaCO}_{3}$ rinds on the undersides of the clast.

\section{RESULTS}

The analytical results for the eight sample suites are listed in table 11.1. Uranium and thorium contents are precise within \pm 2 percent ( 1 sigma). Standard deviation for the ${ }^{234} \mathrm{U} /{ }^{238} \mathrm{U},{ }^{230} \mathrm{Th} /{ }^{238} \mathrm{U}$, and ${ }^{230} \mathrm{Th} /{ }^{232} \mathrm{Th}$ ratios are $1.5,2$, and 1.5 percent, respectively, based on the precision of repeated counts of the chemical separates. The uranium-trend model parameters (Rosholt, 1985) and calculated ages of the eight suites are shown in table 11.2.

Uranium-trend plots of the results for alluvial fan sample suites (BT2F and 2BT2F) show acceptable ranges of isotopic ratios and good linearity (fig. 11.3), yielding estimated ages of $70 \pm 10 \mathrm{ka}$ and $80 \pm 10 \mathrm{ka}$, respectively. Estimated times for the carbonate accumulation in the fan, $41 \pm 3 \mathrm{ka}$ and $68 \pm 4 \mathrm{ka}$ (table 11.3), are consistent with the approximate 75-ka uranium-trend ages for the fan deposit. For the two upper units from trench BF-1 (fig. 11.4) uranium-trend ages of $75 \pm 10 \mathrm{ka}$ and $155 \pm 35 \mathrm{ka}$, respectively, were obtained. Results for two of the three lower fluvial units, (suites BF3 and BF4) indicate negative slopes (fig. 11.5) and uranium-trend ages of $480 \pm 50 \mathrm{ka}$ and $530 \pm 70 \mathrm{ka}$, respectively. Duplicate results for the deeper fluvial unit, (suites BF5 and BF6) are shown in figure 11.6; uranium-trend ages of $540 \pm 100 \mathrm{ka}$ and $460 \pm 90 \mathrm{ka}$, respectively, were obtained. For the three lower fluvial units, the dating method does not provide sufficient resolution to distinguish differences in age. An average age and standard deviation of the values for the three units represented by suites $\mathrm{BF} 3, \mathrm{BF} 4$, and BF5-BF6 is $500 \pm 60 \mathrm{ka}$.

Disseminated carbonized wood fragments $(6 \mathrm{~mm}$ maximum size) occur in the fluvial clayey silt unit (suite BF3; fig. 11.2). A radiocarbon age of $10.0 \pm 0.3 \mathrm{ka}$ was obtained on this carbonaceous material (W-5673; Meyer Rubin, U.S.G.S., written commun., 1985). There is a great difference between the ${ }^{14} \mathrm{C}$ age $(10 \mathrm{ka})$ and the uranium-trend age $(480 \mathrm{ka})$ for this unit. After detailed petrographic study of the carbonaceous material, N.C. Bostick (written commun., 1985) determined that the carbon is not charcoal but coalified pure wood tissue. In a further study using ${ }^{13} \mathrm{C}$ nuclear magnetic resonance spectroscopy and element abundances (H, C, N, O), E.C. Spiker (written commun., 1986) found that the carbonized wood is similar to highly oxidized humic material although he could not rule out charcoal as a possible source of the material. 


\section{DISCUSSION}

The uranium-trend ages indicate that fluvial sediments exposed in trench BF-1 were deposited over a time period extending from the middle into late Pleistocene. We consider these ages to be reliable because (1) plots of ${ }^{234} \mathrm{U}-{ }^{238} \mathrm{U} /$ ${ }^{238} \mathrm{U}$ ) versus $\left.{ }^{238} \mathrm{U}-{ }^{230} \mathrm{Th}\right) /{ }^{238} \mathrm{U}$ show good linearity and extension (Rosholt, 1985), (2) the ages have stratigraphic consistency, and (3) duplicate analyses of the same stratigraphic unit (suites BF5 and BF6) show concordance within experimental error. The uranium-trend ages suggest that all of the lowermost units were deposited about 500,000 yr ago, as dates are all concordant around this age within error limits. Suite $\mathrm{BF} 2$ yielded a significantly younger age of about $155 \mathrm{ka}$ indicating a depositional hiatus between the units represented by suites BF3 and BF2 of about $345 \mathrm{ka}$. If the top of the fluvial silts (suites BF3) was exposed for about 345 ka before deposition of the upper fluvial gravels (suite BF2), then a well-developed paleosol should be present. The absence of a well-developed paleosol at the contact between these two units suggests a major period of erosion sometime between about $500 \mathrm{ka}$ and about $160 \mathrm{ka}$. A similar interpretation can be made for the contact between the upper fluvial gravel (suite BF2) and the silty alluvium (suite BF1) at the surface; the dates suggest a depositional hiatus between about $155 \mathrm{ka}$ and about $75 \mathrm{ka}$. Again, the absence of a well-developed paleosol at the contact between these two units also suggests a major period of erosion some time between about $155 \mathrm{ka}$ and $75 \mathrm{ka}$.
The uranium-trend age estimate of the uppermost unit (Q1c, suite BF1) in trench BF-1 is difficult to evaluate geomorphically or pedologically, but some constraints are possible. There is only weak pedogenic carbonate development in unit Q1c, but a discontinuous, 2-cm-thick zone of $\mathrm{CaCO}_{3}$ accumulation is found at depths of $40-50 \mathrm{~cm}$. This material is $15-20$ percent $\mathrm{CaCO}_{3}$, based on loss on ignition. If the carbonate is pedogenic, it indicates enough carbonate accumulation to suggest a pre-Holocene age for unit QIc, based on rates of carbonate accumulation in alluvium in similar climates as summarized by Machette (1985). The surface there also has a weak stone pavement, with rock varnish found on the pavement clasts (fig. 11.2). Stone pavements can form in as short a time as a few years in arid regions (Sharon, 1962), but observations by many researchers indicate that rock varnish requires several thousand to as much as 10,000 years to form (Dorn and Oberlander, 1982). One can conclude from the combined carbonate and rock-varnish data that unit Qlc is probably older than earliest Holocene and perhaps considerably older.

The results from trench $B F-1$ suggest that a sequence of several alluvial deposits were laid down by the Amargosa River at the base of the Beatty scarp in the last 500,000 yr. The fan deposits actually cut by the Beatty scarp in the vicinity of trench $B F-1$ have not been dated because suitable sampling sites were not found. Presumably, they predate the oldest unit ( $\sim 500 \mathrm{ka}$ ) exposed in trench BF-1 if the scarp is erosional and not tectonic. However, we have dated an alluvial fan truncated by the Beatty scarp approximately

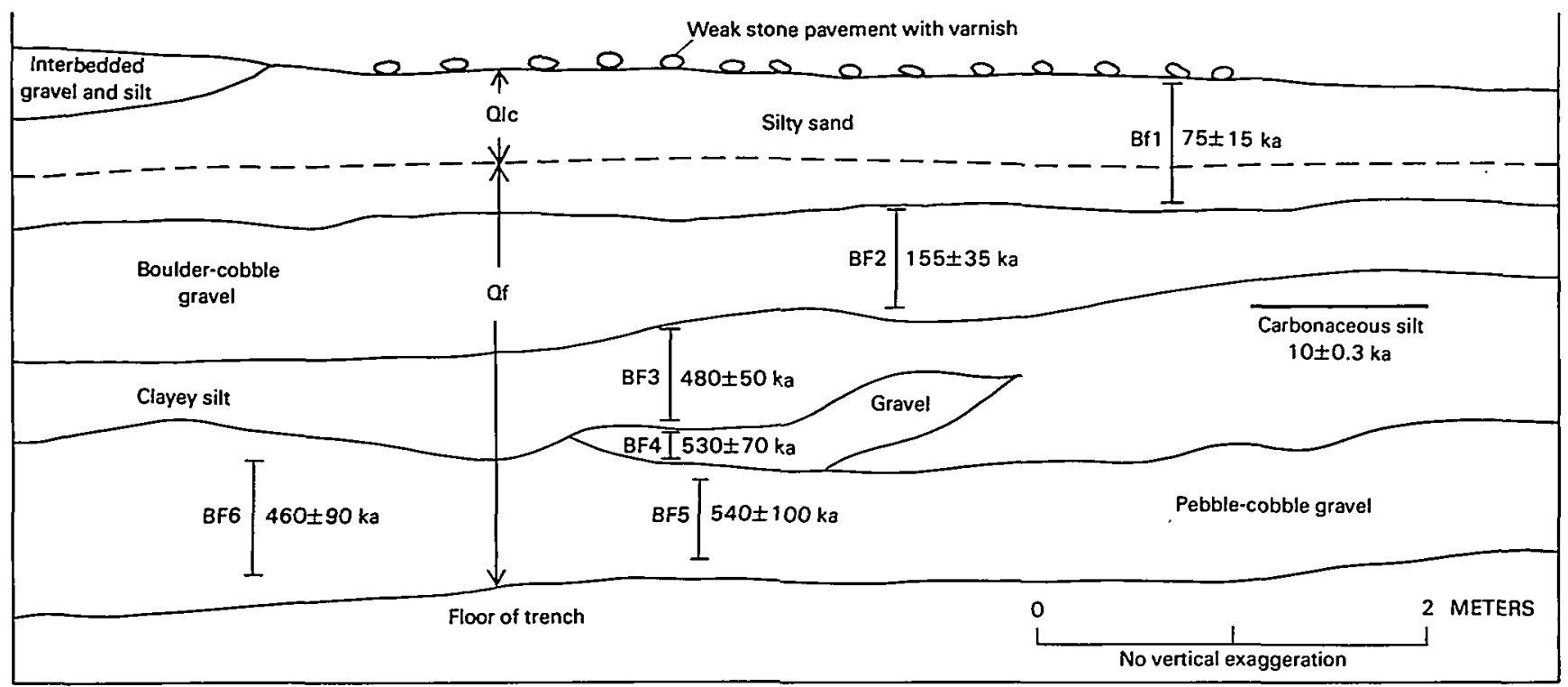

BF2 $\left[\begin{array}{c}\text { Location and number of sample } \\ \text { suites for U-trend dating }\end{array} \quad \begin{array}{c}\text { Location of carbon sample } \\ \text { for }{ }^{14} \mathrm{C} \text { age }\end{array}\right.$

Figure 11.2. Diagram of sampled area on south face of trench BF-1 (fig. 11.1). Modified from trench log of Swadley and others (1986). Qlc, silty alluvium (Swadley and Hoover, 1983); Qf, fluvial sediments (Swadley and Hoover, 1983). Uranium-trend ages shown next to sample locations.

132 Geologic and Hydrologic Investigations, Yucca Mountain, Nevada 
Table 11.1. Sample collection depths, element concentrations, and uranium-series activity ratios

\begin{tabular}{|c|c|c|c|c|c|c|c|}
\hline Sample & $\begin{array}{r}\text { Depth } \\
(\mathrm{cm})\end{array}$ & $\begin{array}{l}\text { Th } \\
(\mathrm{ppm})\end{array}$ & $\begin{array}{l}\mathrm{U} \\
(\mathrm{ppm})\end{array}$ & ${ }^{234} \mathrm{U} /{ }^{238} \mathrm{U}$ & ${ }^{230} \mathrm{Th} /{ }^{238_{\mathrm{U}}}$ & ${ }^{230} \mathrm{Th} /{ }^{232} \mathrm{Th}$ & ${ }^{238} \mathrm{U} / /^{232} \mathrm{Th}$ \\
\hline \multicolumn{8}{|c|}{ Sandy gravel of fan deposit (channel in outcrop) } \\
\hline $\begin{array}{l}\text { BT2F-1 } \\
\text { BT2F-2 } \\
\text { BT2F-3 } \\
\text { BT2F-4 } \\
\text { BT2F-5 } \\
\text { BT2F-6 } \\
\text { BT2F-7 } \\
\text { BT2F-8 }\end{array}$ & $\begin{array}{c}36-47 \\
47-58 \\
58-69 \\
69-80 \\
80-91 \\
91-102 \\
102-113 \\
113-124\end{array}$ & $\begin{array}{l}7.74 \\
11.3 \\
11.2 \\
11.2 \\
12.2 \\
11.9 \\
11.4 \\
11: 3\end{array}$ & $\begin{array}{l}1.18 \\
1.73 \\
1.76 \\
1.96 \\
2.43 \\
2.49 \\
2.29 \\
2.21\end{array}$ & $\begin{array}{l}1.149 \\
1.132 \\
1.157 \\
1.211 \\
1.279 \\
1.295 \\
1.262 \\
1.224\end{array}$ & $\begin{array}{r}1.138 \\
1.110 \\
1.133 \\
: 986 \\
.830 \\
.837 \\
.904 \\
.959\end{array}$ & $\begin{array}{r}0.538 \\
.523 \\
.549 \\
.535 \\
.513 \\
.541 \\
.562 \\
.579\end{array}$ & $\begin{array}{r}0.473 \\
.471 \\
.485 \\
.542 \\
.617 \\
.647 \\
.622 \\
.604\end{array}$ \\
\hline \multicolumn{8}{|c|}{ Sandy gravel of fan deposit (channel in backhoe pit) } \\
\hline $\begin{array}{l}2 B T 2 F-2 \\
2 B T 2 F-3 \\
2 B T 2 F-4 \\
2 B T 2 F-5 \\
2 B T 2 F-6 \\
2 B T 2 F-7 \\
2 B T 2 F-8\end{array}$ & $\begin{array}{l}28-38 \\
38-48 \\
48-58 \\
58-68 \\
68-78 \\
78-88 \\
88-98\end{array}$ & $\begin{array}{l}10.7 \\
11.2 \\
11: 3 \\
10.7 \\
10.3 \\
10.9 \\
10.4\end{array}$ & $\begin{array}{l}1.53 \\
1.51 \\
1.71 \\
2.16 \\
2.29 \\
2.20 \\
2.46\end{array}$ & $\begin{array}{l}1.112 \\
1.101 \\
1.166 \\
1.312 \\
1.281 \\
1.260 \\
1.344\end{array}$ & $\begin{array}{l}1.241 \\
1.187 \\
1.087 \\
.834 \\
.849 \\
.926 \\
.834\end{array}$ & $\begin{array}{r}0.547 \\
.494 \\
.508 \\
.523 \\
.585 \\
.577 \\
.612\end{array}$ & $\begin{array}{r}0.441 \\
.416 \\
.468 \\
.627 \\
.690 \\
.624 \\
.734\end{array}$ \\
\hline
\end{tabular}

Silty alluvium and fluvial sand, trench $\mathrm{BF}-1$

\begin{tabular}{llllllrrr}
\hline BF1-2 & $10-20$ & 14.9 & 2.27 & 1.036 & 1.345 & 0.634 & 0.471 \\
BE1-3 & $20-30$ & 16.4 & 2.67 & 1.083 & 1.204 & .607 & .504 \\
BF1-4 & $30-40$ & 16.2 & 2.51 & 1.114 & 1.247 & .596 & .478 \\
BE1-5 & $40-50$ & 16.8 & 2.85 & 1.155 & 1.104 & .583 & .527 \\
BF1-6 & $50-60$ & 17.9 & 3.21 & 1.191 & 1.066 & .598 & .561 \\
BF1-7 & $60-70$ & 17.6 & 3.25 & 1.193 & 1.054 & .607 & .576 \\
BF1-8 & $70-80$ & 19.4 & 2.91 & 1.118 & 1.154 & .536 & .465 \\
\hline
\end{tabular}

Fluvial gravel, trench $\mathrm{BF}-1$

\begin{tabular}{lrrrrrrr}
\hline BF2-1 & $85-93$ & 16.5 & 2.99 & 1.127 & 1.040 & 0.581 & 0.558 \\
BF2-2 & $93-101$ & 17.9 & 3.33 & 1.158 & 1.008 & .578 & .564 \\
BF2-3 & $101-109$ & 17.8 & 3.27 & 1.151 & $: 995$ & .565 \\
BF2-4 & $109-117$ & 17.4 & 3.16 & 1.184 & 1.001 & .569 & $: 568$ \\
BE2-5 & $117-125$ & 16.7 & 3.39 & 1.205 & .953 & .596 & $: 626$ \\
BE2-6 & $125-133$ & 17.6 & 3.33 & 1.142 & 1.011 & .593 & .587 \\
BE2-7 & $133-141$ & 17.7 & 3.30 & 1.120 & 1.033 & .593 & .574 \\
BE2-8 & $141-149$ & 18.4 & 3.06 & 1.099 & 1.145 & .588 & .513 \\
\hline
\end{tabular}

Fluvial silt, trench $\mathrm{BF}-1$

\begin{tabular}{llllllll}
\hline BF3-1 & $150-157$ & 19.7 & 3.36 & 1.323 & 1.327 & 0.699 & 0.527 \\
BF3-2 & $157-164$ & 19.4 & 3.35 & 1.247 & 1.170 & .626 & .535 \\
BF3-3 & $164-171$ & 17.1 & 2.94 & 1.227 & 1.139 & .604 & .531 \\
BF3-4 & $171-178$ & 14.8 & 2.50 & 1.234 & 1.153 & .602 & .522 \\
BF3-5 & $178-185$ & 17.6 & 2.95 & 1.290 & 1.219 & .632 & .519 \\
BF3-6 & $185-192$ & 20.2 & 3.35 & 1.449 & 1.366 & .700 & .512 \\
BF3-7 & $192-199$ & 15.4 & 2.70 & 1.312 & 1.282 & .694 & .542 \\
BF3-8 & $199-206$ & 18.1 & 2.93 & 1.293 & 1.332 & .668 & .501 \\
\hline & & & & Fluvial grave1, trench BF-1 & & .618 \\
\hline BF4-1 & $210-214$ & 18.4 & 2.90 & 1.264 & 1.267 & 0.618 & 0.488 \\
BF4-2 & $214-218$ & 18.0 & 3.00 & 1.216 & 1.199 & .616 & .514 \\
BF4-3 & $218-222$ & 18.3 & 3.00 & 1.228 & 1.265 & .641 & .507 \\
BF4-4 & $222-228$ & 19.4 & 3.15 & 1.314 & 1.390 & .697 & .501 \\
BF4-5 & $228-232$ & 19.7 & 3.01 & 1.272 & 1.348 & .637 & .472 \\
BF4-6 & $232-236$ & 20.1 & 3.35 & 1.189 & 1.200 & .616 & .514
\end{tabular}


Table 11.1. Sample collection depths, element concentrations, and uranium-series activity ratios-Continued

\begin{tabular}{|c|c|c|c|c|c|c|c|}
\hline Sample & $\begin{array}{l}\text { Depth } \\
(\mathrm{cm})\end{array}$ & $\begin{array}{l}\text { Th } \\
(\mathrm{ppm})\end{array}$ & $\begin{array}{c}\mathrm{U} \\
(\mathrm{ppm})\end{array}$ & ${ }^{234} \mathrm{U} /{ }^{238} \mathrm{U}$ & ${ }^{230} \mathrm{Th} /{ }^{238} \mathrm{U}$ & ${ }^{230} \mathrm{Th} /{ }^{232} \mathrm{Th}$ & ${ }^{238} \mathrm{U} /{ }^{232} \mathrm{Th}$ \\
\hline \multicolumn{8}{|c|}{ Fluvial gravel, trench $\mathrm{BF}-1$} \\
\hline $\begin{array}{l}\text { BF5-1 } \\
\text { BF5-2 } \\
\text { BF5-3 } \\
\text { BF5-4 } \\
\text { BF5-5 } \\
\text { BF5-6 } \\
\text { BF5-7 } \\
\text { BF5-8 }\end{array}$ & $\begin{array}{l}244-250 \\
250-256 \\
256-262 \\
262-268 \\
268-274 \\
274-280 \\
280-286 \\
286-292\end{array}$ & $\begin{array}{l}18.8 \\
17.7 \\
19.3 \\
20.0 \\
18.7 \\
19.7 \\
20.2 \\
19.2\end{array}$ & $\begin{array}{l}2.92 \\
2.71 \\
2.85 \\
2.90 \\
2.74 \\
2.73 \\
2.88 \\
2.65\end{array}$ & $\begin{array}{l}1.163 \\
1.188 \\
1.133 \\
1.227 \\
1.187 \\
1.182 \\
1.145 \\
1.225\end{array}$ & $\begin{array}{l}1.204 \\
1.168 \\
1.072 \\
1.219 \\
1.149 \\
1.136 \\
1.100 \\
1.272\end{array}$ & $\begin{array}{r}0.577 \\
.553 \\
.489 \\
.547 \\
.520 \\
.486 \\
.484 \\
.544\end{array}$ & $\begin{array}{r}0.479 \\
.473 \\
.457 \\
.449 \\
.452 \\
.428 \\
.440 \\
.427\end{array}$ \\
\hline $\begin{array}{l}\text { BF6-1 } \\
\text { BF6-2 } \\
\text { BF6-3 } \\
\text { BF6-4 } \\
\text { BF6-5 } \\
\text { BF6-6 } \\
\text { BF6-7 } \\
\text { BF6-8 }\end{array}$ & $\begin{array}{l}222-232 \\
232-242 \\
242-252 \\
252-262 \\
262-272 \\
272-282 \\
282-292 \\
292-302\end{array}$ & $\begin{array}{l}16.7 \\
16.4 \\
18.4 \\
18.1 \\
18.5 \\
19.1 \\
18.2 \\
18.4\end{array}$ & $\begin{array}{l}2.60 \\
3.00 \\
3.07 \\
3.06 \\
2.84 \\
3.03 \\
2.91 \\
3.06\end{array}$ & $\begin{array}{l}1.180 \\
1.265 \\
1.131 \\
1.187 \\
1.142 \\
1.137 \\
1.133 \\
1.238\end{array}$ & $\begin{array}{l}1.175 \\
1.144 \\
1.070 \\
1.131 \\
1.079 \\
1.098 \\
1.094 \\
1.106\end{array}$ & $\begin{array}{r}.567 \\
.575 \\
.561 \\
.576 \\
.494 \\
.566 \\
.534 \\
.609\end{array}$ & $\begin{array}{l}.482 \\
.502 \\
.525 \\
.509 \\
.458 \\
.516 \\
.488 \\
.551\end{array}$ \\
\hline
\end{tabular}

Table 11.2. Uranium-trend model parameters and ages of depositional units in Beatty area $[\mathrm{F}(\mathrm{O})$, uranium flux]

\begin{tabular}{|c|c|c|c|c|c|}
\hline $\begin{array}{r}\text { Sample } \\
\text { suite }\end{array}$ & Description of deposit & $\begin{array}{l}\text { U-trend } \\
\text { slope }\end{array}$ & $\frac{x}{\text { intercept }}$ & $\begin{array}{l}\text { Half period } \\
\text { of } \mathrm{F}(\mathrm{O}) \\
(\mathrm{ka})\end{array}$ & $\begin{array}{l}\text { Age } \\
(\mathrm{ka})\end{array}$ \\
\hline \multicolumn{6}{|c|}{ Trench BF-2 area } \\
\hline $\mathrm{BT} 2 \mathrm{~F}$ & $\begin{array}{l}\text { Alluvial fan deposit adjacent } \\
\text { to trench } \mathrm{BF}-2 \text { (outcrop } \\
\text { channel). }\end{array}$ & +0.487 & -0.426 & 100 & $70 \pm 10$ \\
\hline 2BT2F & $\begin{array}{l}\text { Alluvial fan deposit adjacent } \\
\text { to trench BF-2 (backhoe } \\
\text { pit channel). }\end{array}$ & +.554 & -.400 & 110 & $80 \pm 10$ \\
\hline \multicolumn{6}{|c|}{ Trench BF-1 } \\
\hline $\mathrm{BF} 1$ & Silty alluvium at surface-n-- & +0.538 & -0.404 & 100 & $75 \pm 154$ \\
\hline BF2 & Upper fluvial gravel-------- & +.588 & -.275 & 240 & $155 \pm 35$ \\
\hline BF3 & Lower fluvial silt & -.753 & +.143 & 520 & $480 \pm 50$ \\
\hline $\mathrm{BF}^{4}$ & 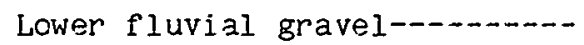 & -.570 & +.155 & 500 & $530 \pm 70$ \\
\hline BE5 & Lower fluvial gravel-n-- & -.490 & +.204 & 420 & $540 \pm 100$ \\
\hline BF6 & $\begin{array}{c}\text { Lower fluvial gravel (same } \\
\text { as BF5). }\end{array}$ & -2.071 & -.026 & 680 & $460 \pm 90$ \\
\hline
\end{tabular}

$1.2 \mathrm{~km}$ south of trench BF-1 (fig. 11.1); this fan is about $55 \mathrm{~m}$ northwest of trench BF-2. Samples taken from a natural exposure along the side of this fan yielded a uranium-trend age estimate of $70 \pm 10 \mathrm{ka}$ (table 11.2). In order to confirm this age, a backhoe pit was dug on a flat, stable part of the fan surface, and samples collected there gave a concordant uranium-trend age estimate of $80 \pm 10 \mathrm{ka}$ (table 11.2). In both cases, the uranium-trend plots are highly linear (correlation coefficients are both 0.98 , significant at the 99.9 percent confidence level). 
As a further test of the uranium-trend age estimates, carbonate rinds from fan clasts were collected in the pit from depths of about $0.5-1.0 \mathrm{~m}$; the rinds are 1-3 mm thick. Two samples were analyzed for conventional closed-system
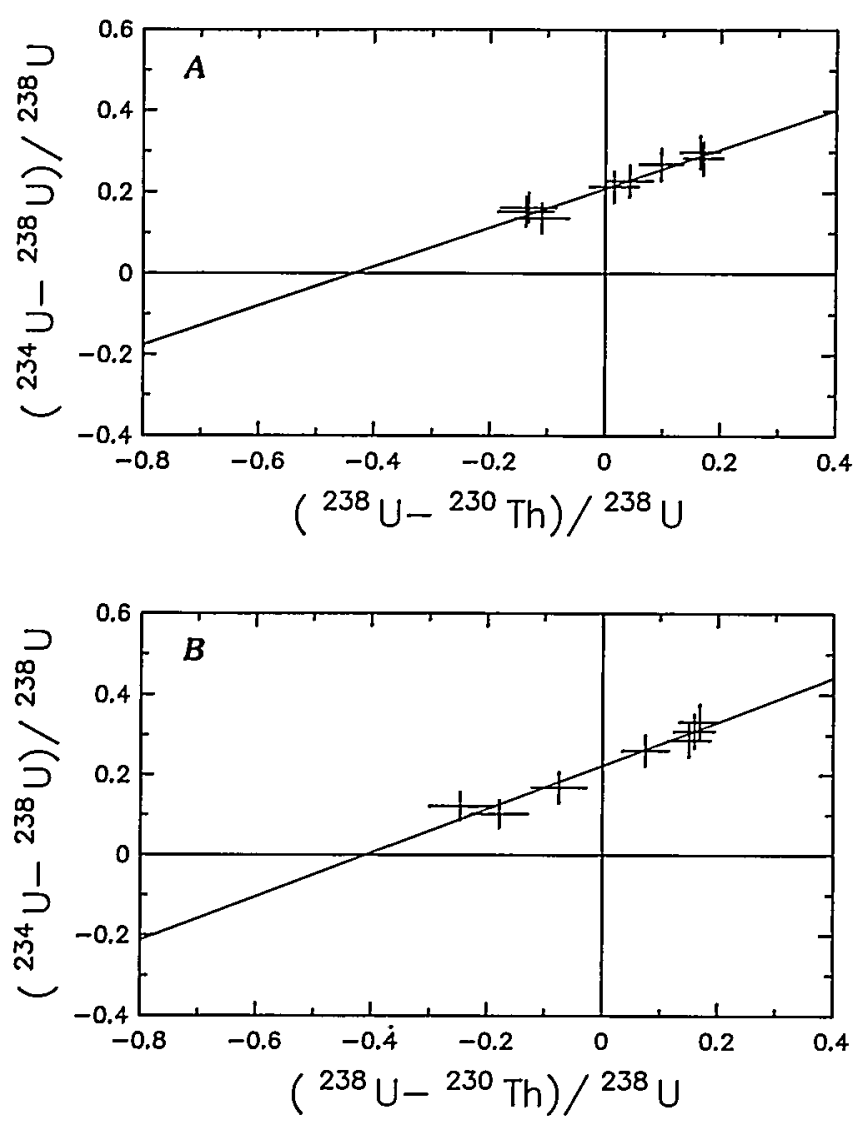

Figure 11.3. Uranium-trend plot of fan alluvium adjacent to trench BF-2 (fig. 11.1). A, Suite BT2F. B, Suite 2BT2F. The $x$-intercept is where regression line intersects zero line for $\left.{ }^{234} U-238 U\right) / 238 U$.
${ }^{230} \mathrm{Th} / 234 \mathrm{U}$ dating that yielded age estimates of $41 \pm 3 \mathrm{ka}$ and $68 \pm 4 \mathrm{ka}$ (table 11.3). These age estimates support the uranium-trend age estimates, because the uranium-trend ages theoretically date the time of deposition of the alluvial fan materials whereas the uranium-series dates should be time integrated age estimates of the period of carbonate accumulation. Because carbonate accumulation had to occur after the fan deposits were stabilized, uranium-series age estimates for the carbonate should be no older than uranium-trend dates of the fan deposits themselves.

Finally, all radiometric determinations on these fan deposits are supported by pedologic and rock-varnish data. The surface of the fan has a well-developed stone pavement, and clasts in the pavement have been strongly varnished. The soil developed in the fan deposits has Stage II carbonate morphology following the scheme of Gile and others (1966). Soils in similar climates with a Stage II carbonate morphology have been estimated to be roughly 60,000 to $120,000 \mathrm{yr}$ old, based on previous uranium-series dates (Ku and others, 1979) and observations summarized by Machette (1985).

The significance of the age estimates of the fan deposits near trench $\mathrm{BF}-2$ is that they provide a maximum age for the Beatty scarp, because they are exposed in the scarp. The results of our studies here are inconsistent with the results from trench BF-1, which suggest that the Beatty scarp is older than $\sim 500 \mathrm{ka}$. Several interpretations of this apparent inconsistency are possible: (1) the alluvial deposits exposed in trench BF-1 may be downfaulted sediments, rather than deposits set in by fluvial processes against a preexisting erosional scarp, in which case the Beatty scarp is of tectonic origin (but see discussion in Swadley and others, chapter 9); (2) the Beatty scarp may have different ages at different localities; or (3) some of the uranium-trend age estimates in the lower units exposed in trench BF-1 may be too old, despite the fact that they meet all criteria for reliable age estimates.

Table 11.3. Concentrations, isotopic activity ratios, and uranium-series age estimates for carbonate pebble rinds in alluvial fan deposits near Beatty trench 2

\begin{tabular}{|c|c|c|c|c|c|c|c|c|c|}
\hline Sample & $\begin{array}{l}\mathrm{CaCO}_{3} \\
\text { (pet) }\end{array}$ & $\underset{\text { (ppm) }}{\text { Th }}$ & $\underset{(\mathrm{ppm})}{U}$ & ${ }^{234} U /^{238} U$ & ${ }^{230}{ }_{\mathrm{Th}} /^{232} \mathrm{Th}$ & ${ }^{230} \mathrm{Th} /{ }^{234} \mathrm{U}$ & $*^{234} U /^{238} U$ & $*^{230} \mathrm{Th} / 234 \mathrm{U}$ & $\begin{array}{c}\text { Age } \\
\text { estimate } \\
\text { (ka) }\end{array}$ \\
\hline 2BT2F-A & 91 & & & & & & & & \\
\hline $\begin{array}{l}\text { leachate-- } \\
\text { residue- }\end{array}$ & - & $\begin{array}{l}1.7 \\
8.5\end{array}$ & $\begin{array}{l}1.18 \\
1.37\end{array}$ & $\begin{array}{l}1.71 \pm 0.03 \\
1.07 \pm .08\end{array}$ & $\begin{array}{r}1.41 \pm 0.02 \\
.42 \pm .01\end{array}$ & $\begin{array}{r}0.39 \pm 0.01 \\
.79 \pm .01\end{array}$ & $1.91 \pm 0.06$ & $0.32 \pm 0.01$ & $41 \pm 3$ \\
\hline 2BT2F-B & 78 & & & & & & & & \\
\hline $\begin{array}{l}\text { leachate- } \\
\text { residue- }\end{array}$ & - & $\begin{array}{l}0.70 \\
5.7\end{array}$ & $\begin{array}{l}1.82 \\
2.60\end{array}$ & $\begin{array}{l}1.72 \pm .02 \\
1.55 \pm .02\end{array}$ & $\begin{array}{l}6.7 \pm .1 \\
1.13 \pm .02\end{array}$ & $\begin{array}{l}.49 \pm .01 \\
.52 \pm .01\end{array}$ & $1.76 \pm .04$ & $.48 \pm .02$ & $68 \pm 4$ \\
\hline
\end{tabular}

*Corrected for detrital ${ }^{230} \mathrm{Th}$ and $\mathrm{U}$ contamination using the isochron-plot method of Szabo and Sterr (1978). Errors reported are based on multiple alpha counts in different detectors $( \pm 1 \sigma)$. 
A serious inconsistency arises from comparison of the uranium-trend age of $480 \mathrm{ka}$ for suite $\mathrm{BF} 3$ and a ${ }^{14} \mathrm{C}$ date on carbonaceous material collected from this same unit. The carbonaceous material yielded a $14 \mathrm{C}$ date of $10 \mathrm{ka}$. The results of the petrographic study that indicate the carbonaceous material is coalified wood tissue rather than charcoal suggests that the carbon may be decomposed remnants of abundant root growth that penetrated the clayey silt horizon about $10 \mathrm{ka}$. We were not able to determine the exact source of the carbon using ${ }^{13} \mathrm{C}$ nuclear magnetic resonance spectroscopy.

\section{CONCLUSIONS}

The following conclusions can be made, based on uranium-trend ages on fluvial deposits from trench $\mathrm{BF}-1$ :
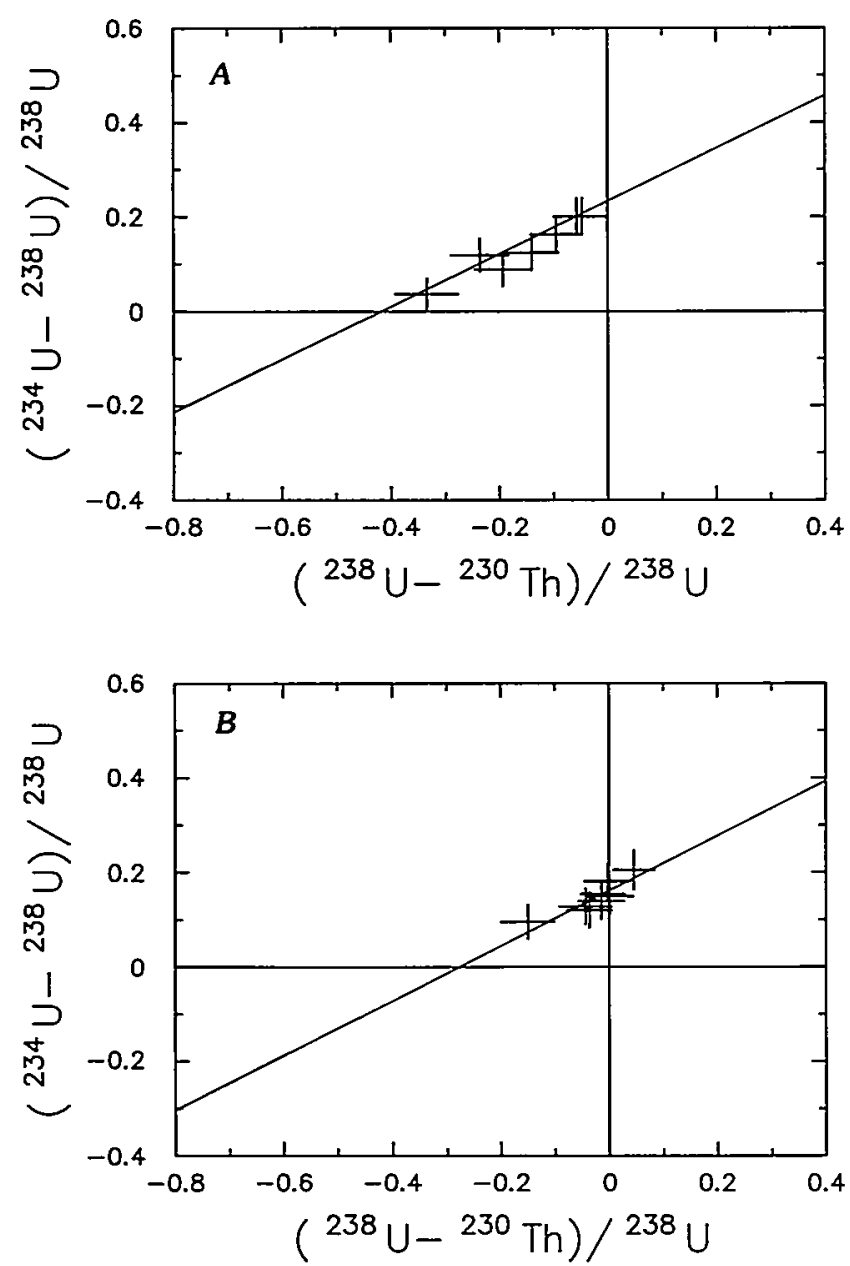

Figure 11.4. Uranium-trend plots of alluvium and fluvial deposit in trench BF-1 (fig. 11.1). A, Suite BF1. B, Suite BF2. The $x$-intercept is where regression line intersects zero line for $\left.\left({ }^{234} \mathrm{U}-238 \mathrm{U}\right)\right)^{238} \mathrm{U}$
(1) deposition of silt, sand, and gravel took place at about 500,155 and $75 \mathrm{ka}$; and (2) erosion took place between 500 and $155 \mathrm{ka}$, and again between 155 and $75 \mathrm{ka}$ as indicated both by the differences in age and by the absence of welldeveloped paleosols between depositional units.

From uranium-trend and uranium-series ages and soil development on fans near trench BF-2, we conclude that the Beatty scarp at that locality is no older than about $80 \mathrm{ka}$. This conclusion is not consistent with the chronology and stratigraphic relations at trench $\mathrm{BF}-1$, which suggests that (1) the Beatty scarp may be of tectonic origin, (2) the Beatty scarp may have different ages at different localites, or (3) some of our age estimates in the lower units of trench $\mathrm{BF}-1$ may be too old. No unambiguous interpretation will be possible without further age control and more detailed examination of the field relations.
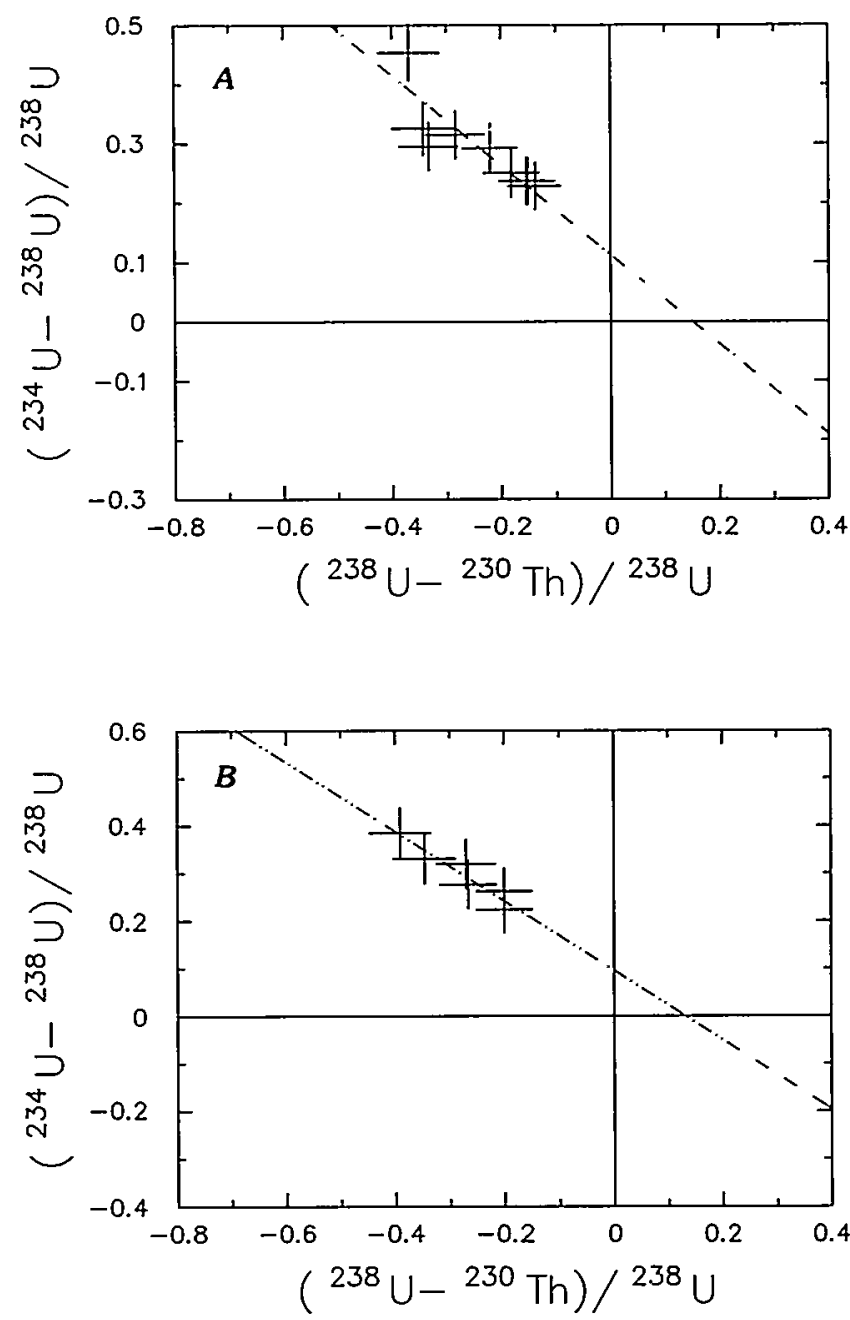

Figure 11.5. Uranium-trend plots of fluvial deposits in trench BF-1 (fig. 11.1). A, Suite BF3. B, Suite BF4. The $x$-intercept is where regression line intersects zero line for $\left({ }^{234} \mathrm{U}-{ }^{238} \mathrm{U}\right) /^{238} \mathrm{U}$. 

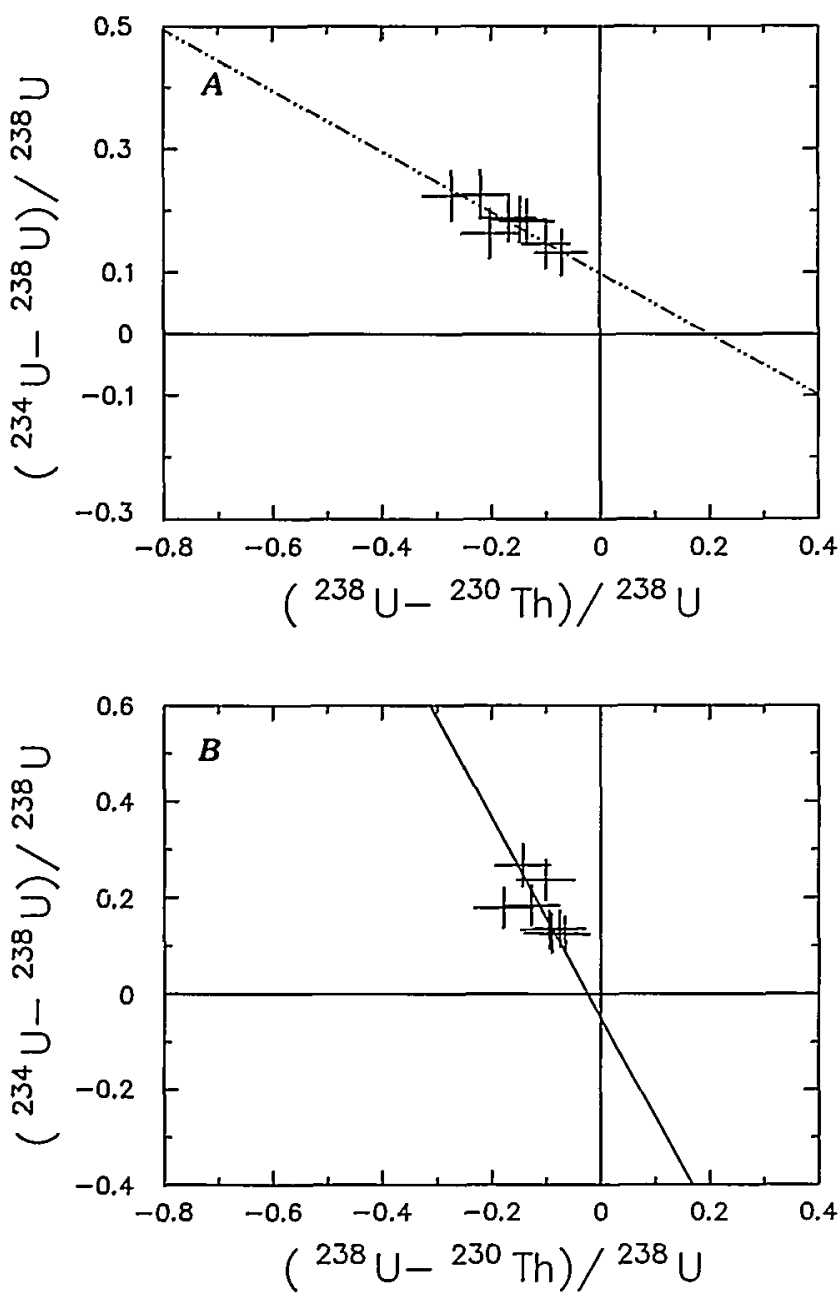

Figure 11.6. Uranium-trend plots of fluvial deposits in trench BF-1 (fig. 11.1). A, Suite BF5. B, Suite BF6. The $x$-intercept is where regression line intersects zero line for $\left.\left({ }^{234} \mathrm{U}-{ }^{238} \mathrm{U}\right)\right)^{238} \mathrm{U}$.

\section{REFERENCES CITED}

Dorn, R.I., and Oberlander, T.M., 1982, Rock varnish: Progress in Physical Geography, v. 6, p. 317-367.

Gile, L.H., Peterson, F.F., and Grossman, R.B., 1966, Morphological and genetic sequences of carbonate accumulation in desert soils: Soil Science, v. 101, p. 347-360.

Ivanovich, M., and Harmon, R.S., 1982, Uranium series disequilibrium: applications to environmental problems: Oxford, Clarendon Press, 571 p.
Ku, T.L., 1976, The uranium-series methods of age determination: Annual Review, Earth and Planetary Science Letters, v. 4, p. 347-379.

Ku, T.L., Bull, W.B., Freeman, S.T., and Knauss, K.G., 1979, $\mathrm{Th}^{230}-\mathrm{U}^{234}$ dating of pedogenic carbonates in gravely desert soils of Vidal Valley, southeastern California: Geological Society of America Bulletin, v. 90, p. 1063-1073.

Ku, T.L., and Liang, Z.C., 1984, The dating of impure carbonates with decay series isotopes: Nuclear Instruments and Methods in Physics Research, v. 223, p. 563-571.

Machette, M.N., 1985, Calcic soils and calcretes of the southwestern United States, in Weide, D. L., ed., Soils and Quaternary geology of the southwestern United States: Geological Society of America Special Paper 203, p. 1-21.

Rosholt, J.N., 1980, Uranium-trend dating of Quaternary sediments: U.S. Geological Survey Open-File Report 80-1087, 65 p.

1984, Radioisotope dilution analyses of geological samples using ${ }^{236} \mathrm{U}$ and ${ }^{229} \mathrm{Th}$ : Nuclear Instruments and Methods in Physics Research, v. 223, p. 572-576.

1985, Uranium-trend systematics for dating Quaternary sediments: U.S. Geological Survey Open-File Report 85-298, $34 \mathrm{p}$.

Rosholt, J.N., Bush, C.A., Carr, W.J., Hoover, D.L., Swadley, W C, and Dooley, J.R., Jr., 1985a, Uranium-trend dating of Quaternary deposits in the Nevada Test Site area, Nevada and California: U.S. Geological Survey Open-File Report 85-540, $72 \mathrm{p}$.

Rosholt, J.N., Bush, C.A., Shroba, R.R., Pierce, K.L., and Richmond, G.M., 1985b, Uranium-trend dating and calibrations for Quaternary sediments: U.S. Geological Survey Open-File Report 85-299, 48 p.

Sharon, D., 1962, On the nature of hamadas in Israel: Zeitschrift für Geomorphologie, v. 6, p. 129-147.

Swadley, W C, and Hoover, D.L., 1983, Geology of faults exposed in trenches in Crater Flat, Nye County, Nevada: U.S. Geological Survey Open-File Report 83-608, 15 p.

Swadley, W C, Hoover, D.L., and Rosholt, J.N., 1984, Preliminary report on late Cenozoic faulting and stratigraphy in the vicinity of Yucca Mountain, Nye County, Nevada: U.S. Geological Survey Open-File Report 84-788, 42 p.

Swadley, W C, Huckins, H.E. and Taylor, E.M., 1986, Logs of the trenches across the Beatty Scarp, Nye County, Nevada: U.S. Geological Survey Miscellaneous Field Studies Map MF-1897.

Szabo, B.J., and Sterr, H., 1978, Dating caliches from southern Nevada by ${ }^{230} \mathrm{Th} /{ }^{232} \mathrm{Th}$ versus ${ }^{234} \mathrm{U} /{ }^{232} \mathrm{Th}$ and ${ }^{234} \mathrm{U} /{ }^{232} \mathrm{Th}$ versus ${ }^{238} \mathrm{U} /{ }^{232} \mathrm{Th}$ isochron-plot method, in Zartman, $\mathrm{R}$. E., ed., Short papers of the 4th International Conference on Geochronology, Cosmochronology and Isotope Geology: U.S. Geological Survey Open-File Report 78-701, p. 416-418.

Vaniman, D.T., Crowe, B.M., and Gladney, E.S., 1982, Petrology and geochemistry of hawaiite lavas from Crater Flat, Nevada: Contributions to Mineralogy and Petrology, v. 80, p. 341-357. 


\title{
12. Relation Between P-Wave Velocity and Stratigraphy of Late Cenozoic Deposits of Southern Nevada
}

\author{
By Eduardo A. Rodriguez and James C. Yount
}

\section{CONTENTS}

\author{
Abstract 139 \\ Introduction 139 \\ Refraction data 139 \\ Discussion 140 \\ References cited 140
}

$30 \mathrm{ft}$ ). The maximum depth resolvable with this array in the materials studied is approximately $18 \mathrm{~m}(60 \mathrm{ft})$.

Previous studies (Duke and others, 1971; Lajoie and others, 1975; Fumal, 1978) have shown a correlation between geologic age and either shear-wave or $P$-wave velocity in noncalcareous Quaternary materials. The present study extends these results to calcareous coarse-grained alluvium and fluvial sediments of southern Nevada.

\section{REFRACTION DATA}

Shallow seismic-refraction studies near Yucca Mountain reveal a correlation between the geologic age of deposits and their measured $P$-wave velocities. The $P$-wave velocities of nearsurface and subsurface layers are correlated with stratigraphic units as mapped at the ground surface and as observed in trenches. This correlation shows a good temporal resolution within the study area, with $P$-wave velocity increasing with inferred stratigraphic age. The $P$-wave velocity of units with similar inferred stratigraphic ages does not vary significantly between sites separated by as much as $60 \mathrm{~km}$. We suggest that the major control of $P$-wave velocities within the stratigraphic units may be the accumulation of secondary pedogenic carbonate rather than differences in grain size or in clast composition; however, no quantitative analysis of lithologic controls has been performed.

\section{INTRODUCTION}

We conducted 37 shallow seismic-refraction investigations in five areas near Yucca Mountain (fig. 12.1), as part of an ongoing study of recent tectonism in the vicinity of a proposed high-level nuclear waste repository (U.S. Geological Survey, 1984). Four of the study areas contain potentially youthful faults and the fifth, the Fortymile Wash area, contains a well-studied sequence of stratigraphic units. During these investigations, a correlation between the age of mapped units and their measured $P$-wave velocities was observed.

Field studies were performed using a Bison model 1580 signal-enhancement seismograph. Methods of operation follow established procedures for portable seismographs (Mooney, 1973; Tinsley, 1984). The seismograph was deployed using an array of six geophones and a sledgehammer signal source (fig. 12.2A). Line lengths ranged from 18 to $110 \mathrm{~m}$ ( 60 to $360 \mathrm{ft}$ ) with geophones aligned away from the signal source at intervals varying from 1.5 to $9 \mathrm{~m}$ ( 5 to
The seismograph enhances the induced seismic signal by cumulatively recording energy from multiple blows of the hammer until the recorded waveforms show distinct $P$-wave arrivals for each geophone on the line. Plotting the $P$-wave arrival times at each geophone against the corresponding distance from the signal source results in points through which best-fit line segments can be drawn (fig. $12.2 B$ ). Ordinary least-squares linear regression was used to determine best-fit lines for the traveltime plots; $r^{2}$ values of 0.97 or greater were achieved for these line segments.

The $P$-wave velocity was determined for respective layers encountered at each survey site. The $P$-wave velocities, intercept times, depths to refracting interfaces, and inferred stratigraphic units for each refraction profile are presented in table 12.1. The $P$-wave velocities corresponding to subsurface layers were tabulated by stratigraphic units (fig. 12.3) as mapped at the surface (Hoover and others, 1981; Fortymile Wash: Swadley and others, 1984) and as observed in fault trenches (Frenchman Flat: Yount and Rodriguez, unpublished trench log; Rock Valley: Yount and others, 1987; Crater Flat: Swadley and Hoover, 1983; Swadley and others, 1984; Beatty: Swadley and others, 1986).

The ranges of $P$-wave velocities for stratigraphic units among the study sites overlap to a small degree (possibly owing to seismic lines being arrayed across very thin veneers of surficial materials) and hence may reflect the limit of accuracy and resolution of the method. In order to test and isolate any regional variation in velocity, we calculated the mean of $P$-wave velocities for each stratigraphic unit encountered at each study site separately. Then we calculated the mean of the sum of $P$-wave velocities for each unit at all study sites together (table 12.2). Finally, we grouped stratigraphic subdivisions together within the stratigraphic framework, and labeled these with the suffix "u" (for 
example, units Q1a, Q1b, and Q1c considered together are labeled Q1u in this report). These composite units were treated the same as individual stratigraphic units in calculating the means of $P$-wave velocities at each site and also for the study area as a whole (table 12.2).

One-way analysis of variance shows that the variation among the mean $P$-wave velocities of the stratigraphic units at all sites is significantly greater than variation due to random error (calculated $F$-ratio $=39.13 ; F$-ratio at the 1 percent level =2.15).

\section{DISCUSSION}

Tabulation of the means of $P$-wave velocities for the various stratigraphic units shows that $P$-wave velocity correlates well with inferred stratigraphic age (fig. 12.4). The good temporal resolution within any given area contrasts with the distribution of $P$-wave velocities from site to site (fig. 12.5). One exception to the trend that velocity increases with age is found in the Beatty study area. At this locale, deposits mapped as unit Q2b on the basis of terrace altitude and pavement development have comparatively low $P$-wave velocities (table 12.2). Recent radiocarbon dating of dispersed organic fragments from a trench in these deposits suggests a Holocene age for this unit (Swadley and others, chapter 9); however, dating of the deposits by uranium-trend methods yields an age of $70 \pm 15 \mathrm{ka}$ (Rosholt and others, chapter 11). Clearly, the velocities for this unit ( 367 to $546 \mathrm{~m} / \mathrm{s}$ ) group more closely with deposits (Q1a, Q1b, Q1c) of Holocene age.

We suggest that the $P$-wave velocity increases with stratigraphic age owing to the accumulation, with time, of secondary pedogenic carbonate. Units Q1a, Q1b, and Q1c lack secondary carbonate or, at best, show weak Stage I carbonate development. ${ }^{1}$ Units Q2a, Q2b, and Q2c can be moderately to well cemented and can even contain some Stage IV (laminar) development. Unit QTa consistently contains a thick, dense caliche (Stage IV) in the upper meter or more of the deposit. At one locality (Line RV-2; Yount and others, 1987) a trench adjacent to a closely spaced refraction line confirms that the principal lithologic change at the depth of the most prominent refractor $(1 \mathrm{~m})$ is a moderately developed laminated soil carbonate within an accumulation of gravel of unit Q2c.

If laminated soil carbonate cementation is controlling seismic refraction, then depths to refracting layers may not correspond exactly to stratigraphic horizon boundaries. We do not know how removal of laminated soil carbonate and subsequent deposition of a younger unit will affect derived $P$-wave velocity for this unconformable interface, because

1Pedogenic carbonate stage designations as used by Birkeland (1984), table A-4, p. 358-359. we have not encountered this situation in the field. We suppose that this stratigraphic configuration would either yield a low $P$-wave refraction velocity for the underlying unit, or result in an overestimate of the thickness of the upper unit.

\section{REFERENCES CITED}

Birkeland, P.W., 1984, Soils and geomorphology: New York, Oxford University Press, $372 \mathrm{p}$.

Dobrin, M.B., 1976, Introduction to geophysical prospecting: New York, McGraw-Hill, 622 p.

Duke, C.M., Johnson, J.A., Kharraz, Y., Campbell, K.W., and Malpiede, N.A., 1971, Subsurface site conditions and geology in the San Fernando earthquake area: University of California, Los Angeles, School of Engineering and Applied Science Report UCLA-ENG-7206, 118 p.

Fumal, T.E., 1978, Correlations between seismic wave velocities and physical properties of geologic materials, San Francisco Bay Region, California: U.S. Geological Survey Open-File Report 78-1067, 114 p.

Hinrichs, E.N., 1968, Geologic map of the Camp Desert Rock quadrangle, Nye County, Nevada: U.S. Geological Survey Geologic Quadrangle Map GQ-726, scale 1:24,000.

Hoover, D.L., Swadley, W C, and Gordan, A.J., 1981, Correlation characteristics of surficial deposits with a description of surficial stratigraphy in the Nevada Test Site region: U.S. Geological Survey Open-File Report 81-512, 27 p.

Lajoie, K.R., and Helley, E.J., 1975, Differentiation of sedimentary deposits for purposes of seismic zonation, in Borcherdt, R.D., ed., Studies for seismic zonation of the San Francisco Bay Region: U.S. Geological Survey Professional Paper 941-A, p. A39-A51.

Mooney, H.M., 1973, Handbook of engineering seismology: Minneapolis, Bison Instruments, $104 \mathrm{p}$.

Swadley, W C, and Hoover, D.L., 1983, Geology of faults exposed in trenches in Crater Flat, Nye County, Nevada: U.S. Geological Survey Open-File Report 83-608, 15 p.

Swadley, W C, Hoover, D.L., and Rosholt, J.N., 1984, Preliminary report on late Cenozoic faulting and stratigraphy in the vicinity of Yucca Mountain, Nye County, Nevada: U.S. Geological Survey Open-File Report 84-788, 42 p.

Swadley, W C, Huckins, H.E., and Taylor, E.M., 1986, Logs of trenches across the Beatty scarp, Nye County, Nevada: U.S. Geological Survey Miscellaneous Field Studies Map MF-1897.

Tinsley, J.C., 1984, Seismic refraction studies of the thickness of alluvium in the Wolverton ground-water basin and beneath Crescent Meadow, in Wahrhaftig, Clyde, Geomorphology and glacial geology, Wolverton and Crescent Meadow areas and vicinity, Sequoia National Park, California: U.S. Geological Survey Open-File Report 84-400, p. 40-52.

U.S. Geological Survey, 1984, A summary of geologic studies through January 1, 1983, of a potential high-level radioactive waste repository site at Yucca Mountain, Nye County, Nevada: U.S. Geological Survey Open-File Report 84-792, 103 p.

Yount, J.C., Shroba, R.R., McMasters, C.R., Huckins, H.E., and Rodriguez, E.A., 1987, Trench logs from a strand of the Rock Valley fault system, Nevada Test Site, Nye County, Nevada: U.S. Geological Survey Miscellaneous Field Studies Map MF-1824. 
FIGURES 12.1-12.5

AND TABLES 12.1, 12.2 


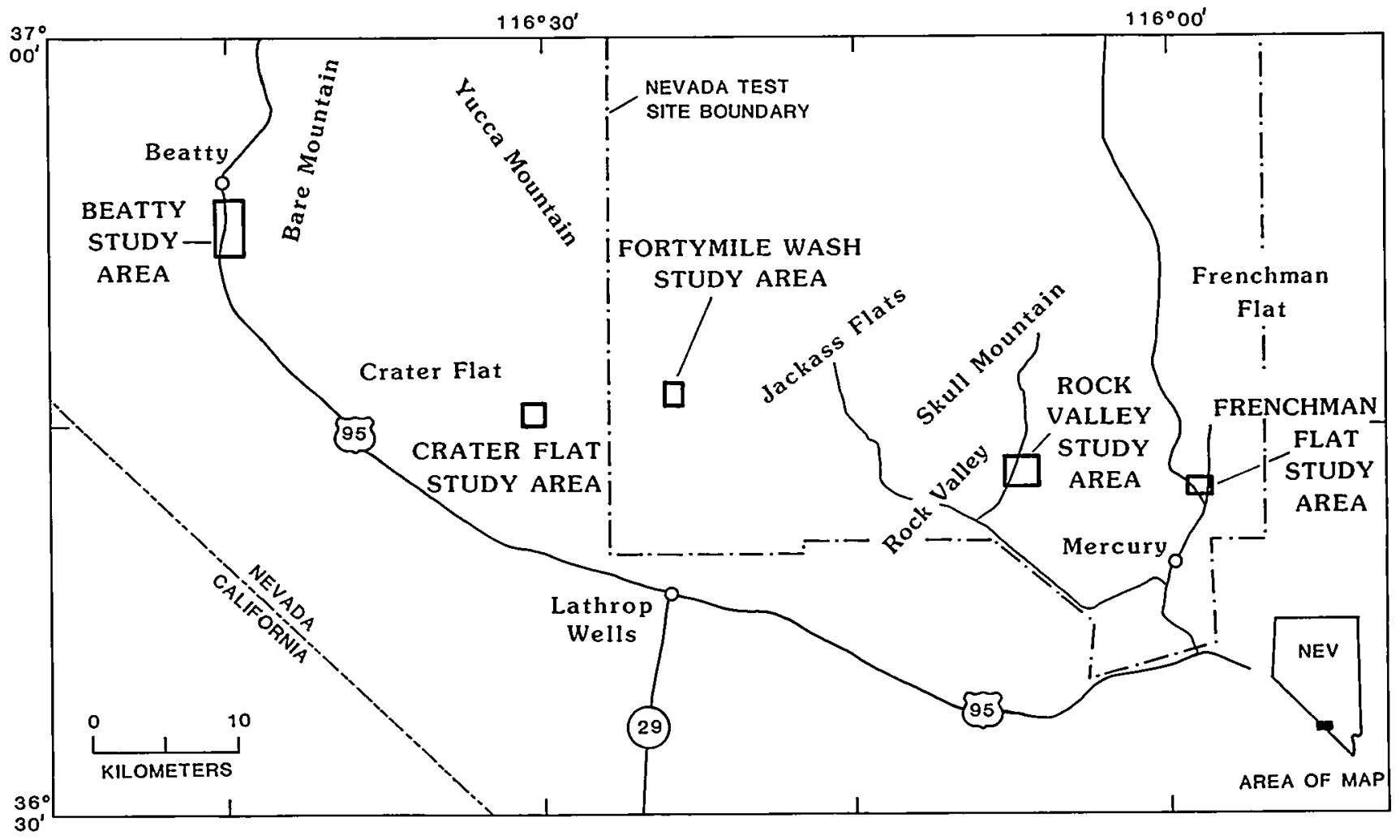

Figure 12.1. Location map showing study areas near Yucca Mountain and the Nevada Test Site.
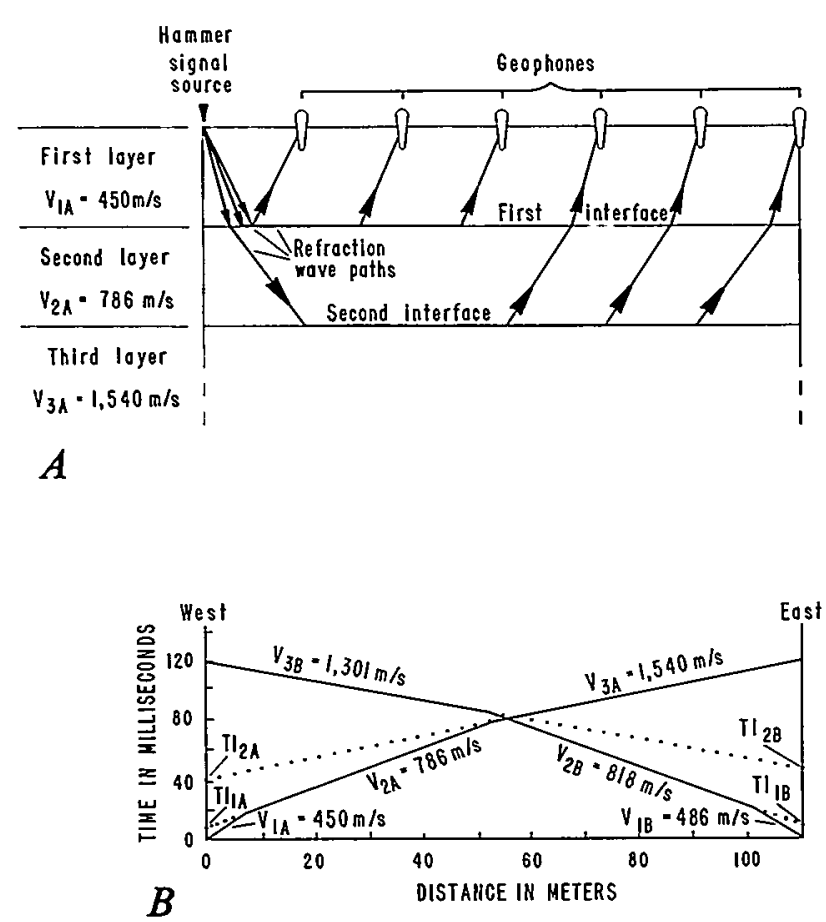

Figure 12.2. Schematic vertical section and three-layer model (A) illustrating refracted wave paths (modified from Mooney, 1973; Dobrin, 1976). $V_{1 A}, V_{2 A}, V_{3 A}, P$-wave velocity of respective subsurface layers. Traveltime plot $(B)$ of typical reversed refraction line. $\mathrm{Tl}_{1 \mathrm{~A}}, \mathrm{Tl}_{2 \mathrm{~A}}, \mathrm{Tl}_{1 B}$, and $\mathrm{Tl}_{2 B}$, intercept times. Velocity in meters per second.
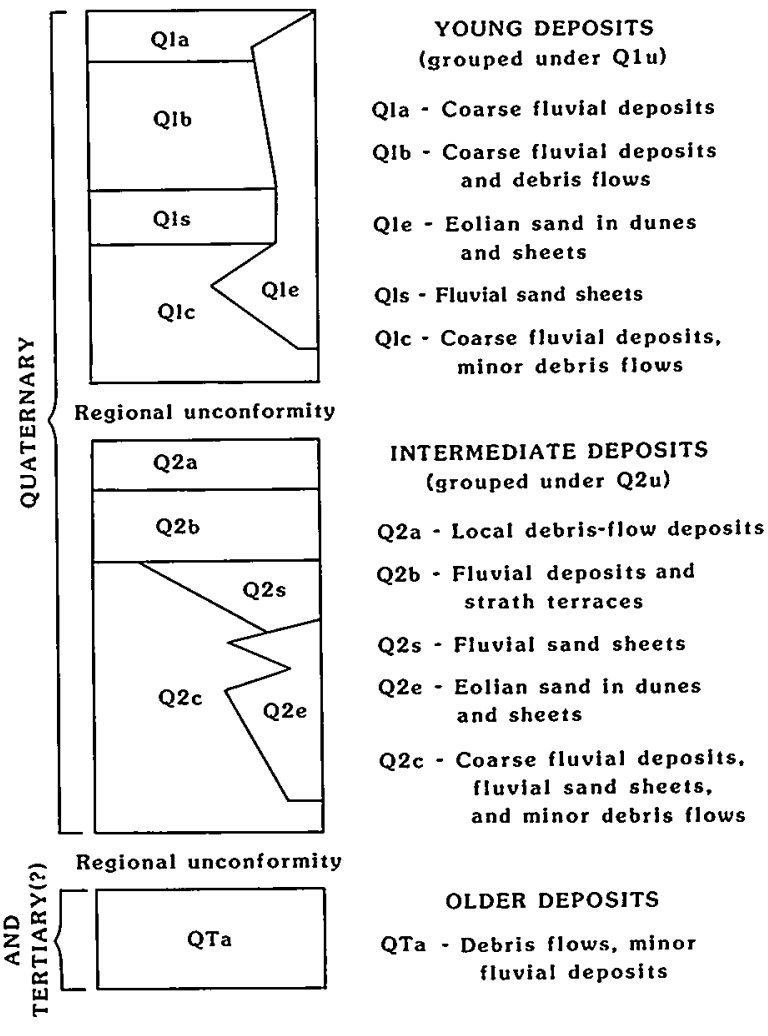

YOUNG DEPOSITS

(grouped under $Q 1 u$ )

Qla - Coarse fluvial deposits

QIb - Coarse fluvial deposits and debris flows

Q1e - Eolian sand in dunes and sheets

Qls - Fluvial sand sheets

Qlc - Coarse fluvial deposits, minor debris tlows

\section{INTERMEDIATE DEPOSITS}

(grouped under Q2u)

Q2a - Local debris-flow deposits

Q2b - Fluvial deposits and strath terraces

Q2s - Fluvial sand sheets

Q2e - Eolian sand in dunes and sheets

Q2c - Coarse fluvial deposits. fluvial sand sheets, and minor debris flows

OLDER DEPOSITS

QTa - Debris flows, minor fluvial deposits

Figure 12.3. Correlation chart showing principal surficial geologic units in the Nevada Test Site region (from Swadley and Hoover, 1983, as modified from Hoover and others, 1981). 


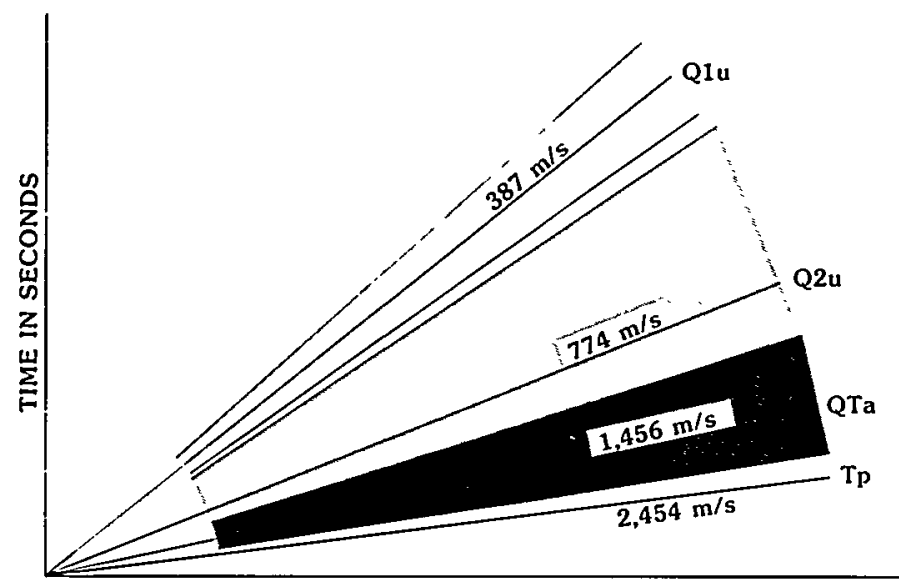

DISTANCE IN METERS
Figure 12.4. Averaged $P$-wave velocities and ranges (shaded regions) for all stratigraphic units (unit QTa of Hoover and others, 1981, unit Q1u, and unit Q2u) for all study sites together. Single $P$-wave refraction velocity determined for a Tertiary bedrock unit (unit Tp, rocks of Pavits Spring of Hinrichs, 1968) of interbedded siltstone and tuff in the Rock Valley study area. Map-unit symbols: Q1u, units Q1a, Q1b, and Q1c (composite) of Hoover and others, 1981; Q2u, units Q2a, Q2b, and Q2c (composite) of Hoover and others, 1981.
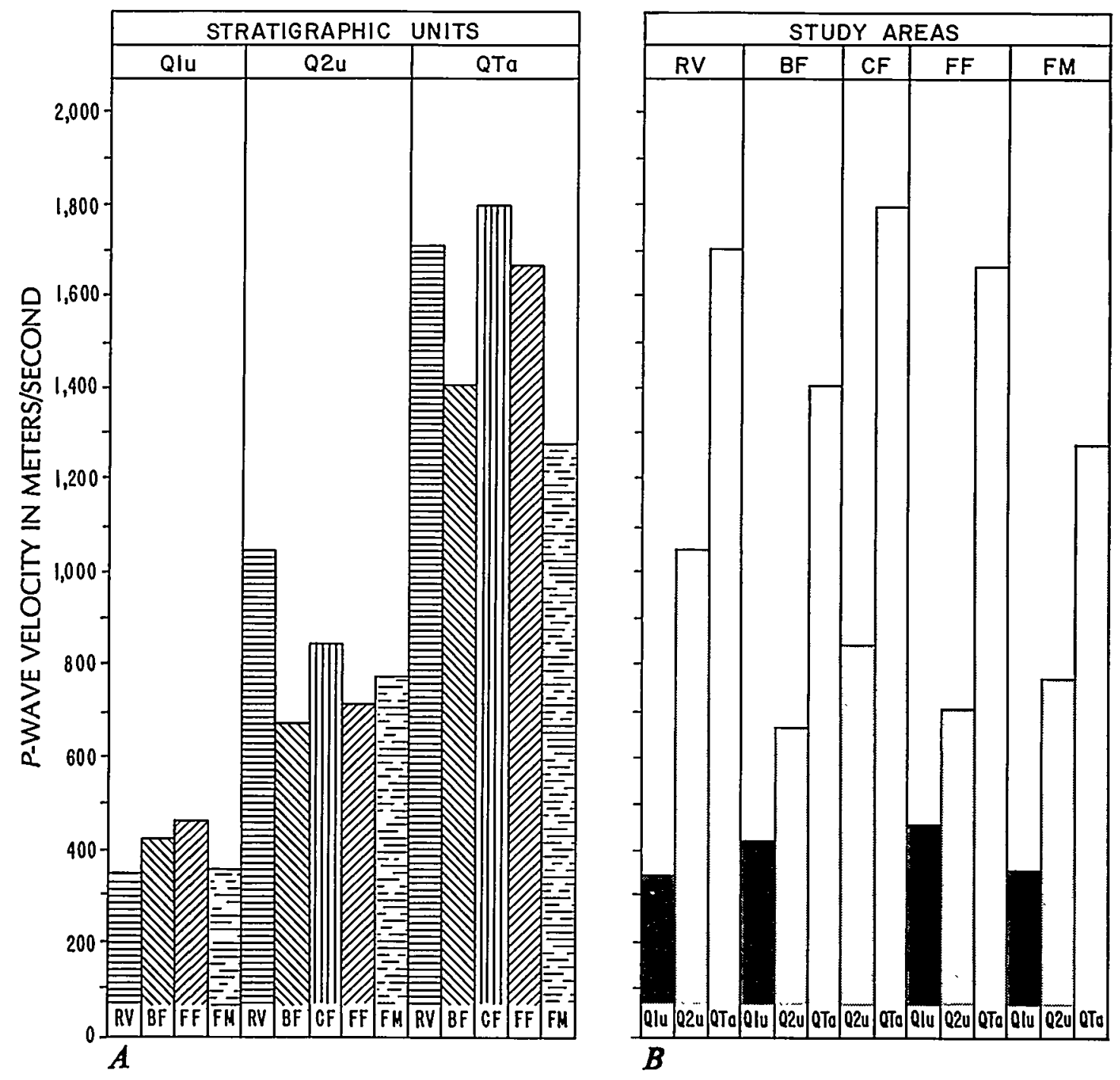

Figure 12.5. Histograms grouped by $(A)$ stratigraphic unit and $(B)$ study area, showing mean $P$-wave velocity. Symbols: RV, Rock Valley; BF, Beatty area; CF, Crater Flat; FF, Frenchman Flat; and FM, Fortymile Wash. Mapunit symbols: Q1u, units Q1a, Q1b, and Q1c (composite) of Hoover and others, 1981; Q2u, units Q2a, Q2b, and Q2c (composite) of Hoover and others, 1981; QTa, gravel unit QTa of Hoover and others, 1981. See figure 12.1 for location of study areas. 
Table 12.1. Results of seismic-refraction survey lines

[ln, length of survey line; int, interval between geophones; az, compass azimuth direction of survey lines; $V, P$-wave velocity corresponding to subsequent layers: subscripts 1,2 , and 3, subsequent subsurface layers; subscripts $\mathrm{A}$ and $\mathrm{B}$, survey line directions (reversed lines). Intercept times were produced by projecting line segment of corresponding $P$-wave velocity to origin (see fig. 12.2A); subscripts same as for velocity. Depth to interface refers to depth from surface to refracting interface; $D_{1 A}, D_{1 B}$ is thickness of first layer; $D_{2 A}, D_{2 B}$ is thickness of second layer. Stratigraphic unit designations are as mapped at the surface from Hoover and others (1981); Fortymile Wash, Swadley and others (1984) and as observed in fault trenches; Frenchman Flat, Yount and Rodriguez (unpublished trench log); Rock Valley, Yount and others (1987); Crater Flat, Swadley and Hoover (1983); Swadley and others (1984); Beatty area, Swadley and others (1986). $\mathrm{L}_{1}, \mathrm{~L}_{2}, \mathrm{~L}_{3}$, subsequent subsurface layers; und, underlying material present but unit designation not determined; $\mathrm{CaCO}_{3}$, calcium carbonate layer at or near surface; Tv?, possible silicic volcanic unit at depth in Crater Flat]

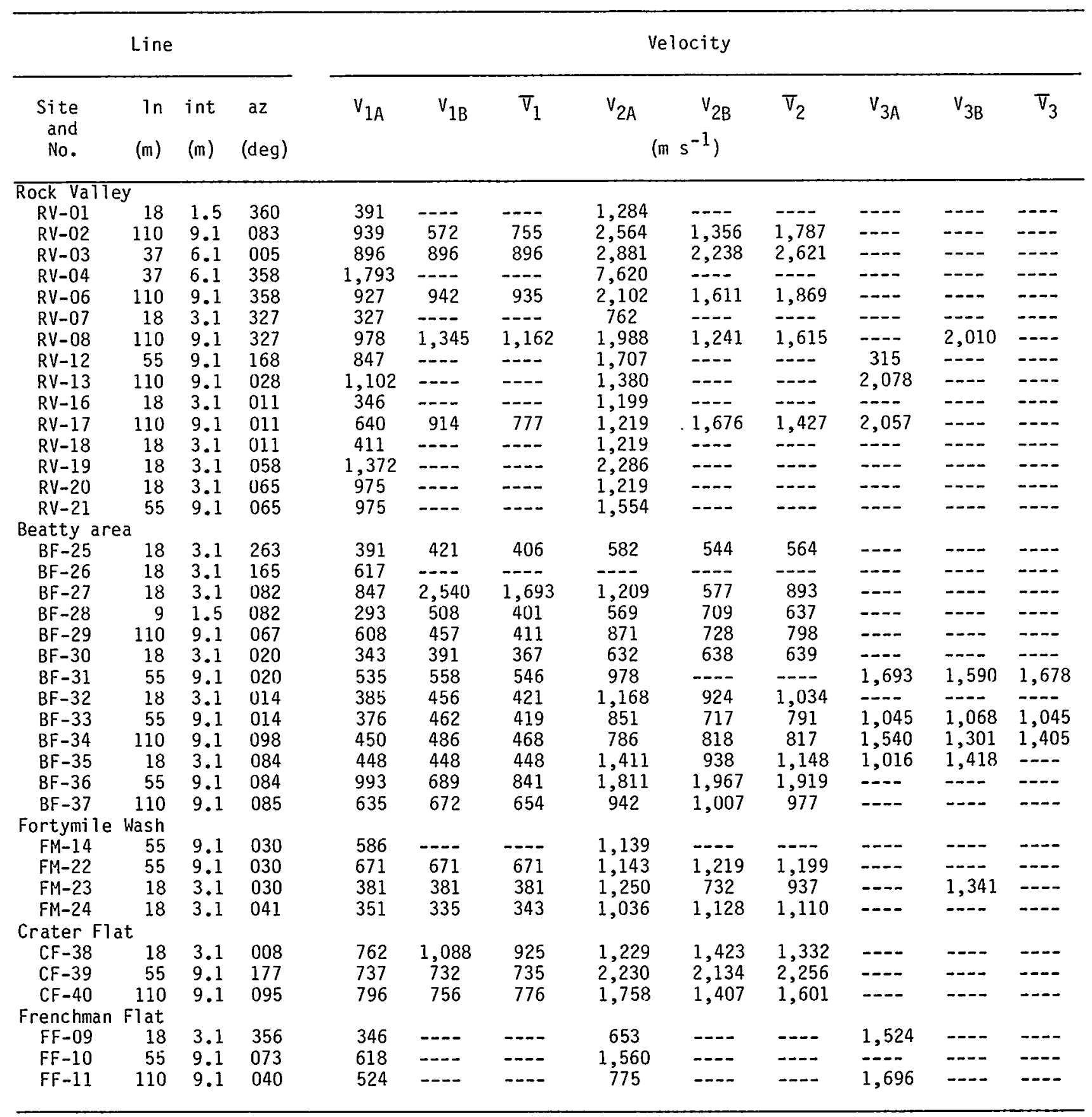




\begin{tabular}{|c|c|c|c|c|c|c|c|c|c|c|}
\hline \multicolumn{4}{|c|}{ Intercept time } & \multicolumn{4}{|c|}{ Depth to interface } & \multicolumn{3}{|c|}{ Units } \\
\hline $\mathrm{TI}_{1 \mathrm{~A}}$ & $\begin{array}{c}{ }^{T I_{1 B}} \\
\left(1 \times 10^{-}\right.\end{array}$ & $(3 \mathrm{~s})$ & $\mathrm{TI}_{2 \mathrm{~B}}$ & $\mathrm{D}_{1 \mathrm{~A}}$ & $\begin{array}{l}D_{1 B} \\
(m)\end{array}$ & $D_{2 A}$ & $\mathrm{D}_{2 \mathrm{~B}}$ & $\mathrm{~L}_{1}$ & $\mathrm{~L}_{2}$ & $\mathrm{~L}_{3}$ \\
\hline $\begin{array}{l}0.0051 \\
.0179 \\
.0048 \\
.0051 \\
.0338 \\
.0156 \\
.0306 \\
.0053 \\
.0016 \\
.0064 \\
.0070 \\
.0048 \\
.0010 \\
.0017 \\
.0045\end{array}$ & $\begin{array}{c}0.0077 \\
0.0044 \\
\cdots 0.0191 \\
-\cdots- \\
0.0043 \\
\cdots-- \\
-\cdots- \\
0.020 \\
-\cdots- \\
-\cdots \\
-\cdots\end{array}$ & 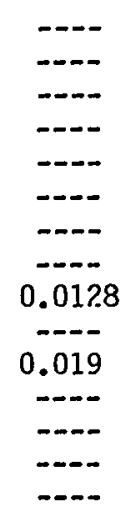 & $\begin{array}{c}---- \\
---- \\
---- \\
---- \\
---- \\
---- \\
0.0334 \\
---- \\
---- \\
--- \\
--- \\
--- \\
--- \\
--- \\
---\end{array}$ & $\begin{array}{r}0.9 \\
7.6 \\
2.4 \\
4.6 \\
18.6 \\
2.7 \\
18.6 \\
2.4 \\
1.5 \\
1.2 \\
3.4 \\
0.9 \\
0.9 \\
1.5 \\
2.7\end{array}$ & $\begin{array}{r}3 . \overline{3} \\
2.1 \\
-\overline{-} \\
10.4 \\
-\overline{-} \\
6.4 \\
\overline{--} \\
-- \\
9.5 \\
-- \\
-- \\
--\end{array}$ & $\begin{array}{r}-- \\
-- \\
-- \\
-- \\
-- \\
-- \\
-- \\
11.6 \\
-- \\
11.6 \\
-- \\
-- \\
--\end{array}$ & $\begin{array}{l}-- \\
-- \\
-- \\
-- \\
-- \\
-- \\
-- \\
-- \\
-- \\
-- \\
--\end{array}$ & $\begin{array}{l}\text { Q1c } \\
\text { Q2c? } \\
02 c ? \\
\text { QTa } \\
\text { Q2c } \\
\text { Q1c } \\
\text { Q2c } \\
\text { Q2c } \\
\text { Q2b } \\
\text { Q1a } \\
\text { Q2b } \\
\text { Q1c } \\
\text { QTa } \\
\text { Q2b } \\
\text { Q2b }\end{array}$ & $\begin{array}{l}\text { QTa } \\
\text { Qta } \\
\text { Tp } \\
\text { und } \\
\text { QTa } \\
\text { Q2c } \\
\text { QTa } \\
\text { QTa } \\
\text { Q2c } \\
\text { Q2c } \\
\text { Q2c } \\
\text { QTa } \\
\text { Tp } \\
\text { QTa } \\
\text { QTa }\end{array}$ & $\begin{array}{l}--- \\
--- \\
--- \\
-- \\
\text { und } \\
-- \\
\text { QTa } \\
-- \\
\text { QTa } \\
--- \\
-- \\
---\end{array}$ \\
\hline $\begin{array}{l}.0069 \\
--.- \\
-. .017 \\
.0017 \\
.0249 \\
.0034 \\
.0194 \\
.0163 \\
.0091 \\
.0067 \\
.0046 \\
.0182 \\
.0093\end{array}$ & $\begin{array}{c}0.0055 \\
---- \\
-.0005 \\
0.0005 \\
0.0067 \\
0.0036 \\
---- \\
0.0116 \\
0.0070 \\
0.0078 \\
0.0034 \\
0.0325 \\
0.0070\end{array}$ & $\begin{array}{c}---- \\
---- \\
---- \\
---- \\
---- \\
--.- \\
0.0389 \\
---- \\
0.0174 \\
0.0398 \\
0.0011 \\
---- \\
---\end{array}$ & $\begin{array}{c}---- \\
---- \\
---- \\
---- \\
--- \\
--- \\
0.0344 \\
---- \\
0.0166 \\
0.0349 \\
0.0069 \\
---- \\
----\end{array}$ & $\begin{array}{l}2.1 \\
1.5 \\
1.2 \\
0.3 \\
6.1 \\
0.9 \\
6.4 \\
3.7 \\
2.1 \\
1.8 \\
1.2 \\
8.5 \\
4.0\end{array}$ & $\begin{array}{r}1.5 \\
-. \\
\ddot{0.1} \\
1.5 \\
0.9 \\
6.4 \\
2.7 \\
1.8 \\
2.1 \\
0.9 \\
15.2 \\
3.1\end{array}$ & $\begin{array}{r}-- \\
-- \\
-- \\
-- \\
-- \\
-- \\
3.4 \\
-- \\
1.4 \\
4.9 \\
-- \\
-- \\
--\end{array}$ & $\begin{array}{r}-- \\
-- \\
-- \\
-- \\
-- \\
-- \\
10.1 \\
\overline{-} \\
5.5 \\
13.1 \\
-- \\
-- \\
--\end{array}$ & 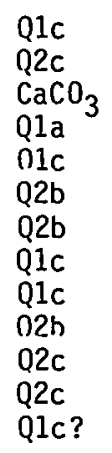 & $\begin{array}{l}\mathrm{Q} 2 \mathrm{c} \\
--- \\
--- \\
\mathrm{CaCO}_{3} \\
\text { Q2c } \\
\text { Q2c } \\
\text { Q2c } \\
\text { Q2c } \\
\text { Q2c } \\
02 \mathrm{c} \\
\text { QTa } \\
\text { QTa } \\
\text { Q2c? }\end{array}$ & $\begin{array}{l}--- \\
--- \\
--- \\
--- \\
--- \\
\text { QTa } \\
--- \\
\text { QTa } \\
\text { QTa } \\
--- \\
--- \\
---\end{array}$ \\
\hline $\begin{array}{l}.0076 \\
.0055 \\
.0090 \\
.0110\end{array}$ & $\begin{array}{l}----- \\
0.0090 \\
0.0037 \\
0.0107\end{array}$ & \begin{tabular}{l}
---- \\
\hdashline-- \\
---- \\
---
\end{tabular} & 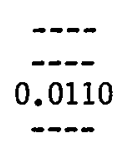 & $\begin{array}{l}2.7 \\
2.1 \\
1.8 \\
2.1\end{array}$ & $\begin{array}{l}-\overline{-} \\
3.7 \\
0.9 \\
1.8\end{array}$ & $\begin{array}{l}-- \\
-- \\
--\end{array}$ & $\begin{array}{l}-- \\
-- \\
--\end{array}$ & $\begin{array}{l}\text { 02. } \\
\text { Q2c } \\
\text { Q2a } \\
\text { Q1c }\end{array}$ & & $\begin{array}{l}--- \\
--- \\
\text { QTa? } \\
---\end{array}$ \\
\hline $\begin{array}{l}.0024 \\
.0126 \\
1.0188\end{array}$ & $\begin{array}{l}0.0019 \\
0.0112 \\
0.0227\end{array}$ & ---- & --.- & $\begin{array}{l}1.5 \\
4.9 \\
8.5\end{array}$ & $\begin{array}{r}1.2 \\
4.3 \\
10.1\end{array}$ & $\begin{array}{l}-- \\
--\end{array}$ & $\begin{array}{l}-- \\
--\end{array}$ & $\begin{array}{l}\mathrm{Q} 2 \mathrm{c} \\
\mathrm{Q} 2 \mathrm{C} \\
\mathrm{Q} 2 \mathrm{~b}\end{array}$ & & $\begin{array}{l}--. \\
--- \\
--\end{array}$ \\
\hline $\begin{array}{l}1.0064 \\
1.0091 \\
1.0083\end{array}$ & $\begin{array}{c}0.0041 \\
\ldots \ldots\end{array}$ & $\overline{0.0402}$ & $\begin{array}{c}0.0148 \\
-\ldots \\
\ldots-\end{array}$ & $\begin{array}{l}-- \\
3.1 \\
3.1\end{array}$ & $\begin{array}{r}0.9 \\
-- \\
--\end{array}$ & $\begin{array}{r}3.1 \\
-\overline{-3}\end{array}$ & $\begin{array}{l}-- \\
--\end{array}$ & $\begin{array}{l}\text { Q1c } \\
\text { Q2c } \\
\text { Q1c }\end{array}$ & $\begin{array}{l}\text { Q2c } \\
\text { QTa } \\
\text { Q2c }\end{array}$ & $\begin{array}{l}\text { QTa } \\
\overline{\text { QTa }}\end{array}$ \\
\hline
\end{tabular}




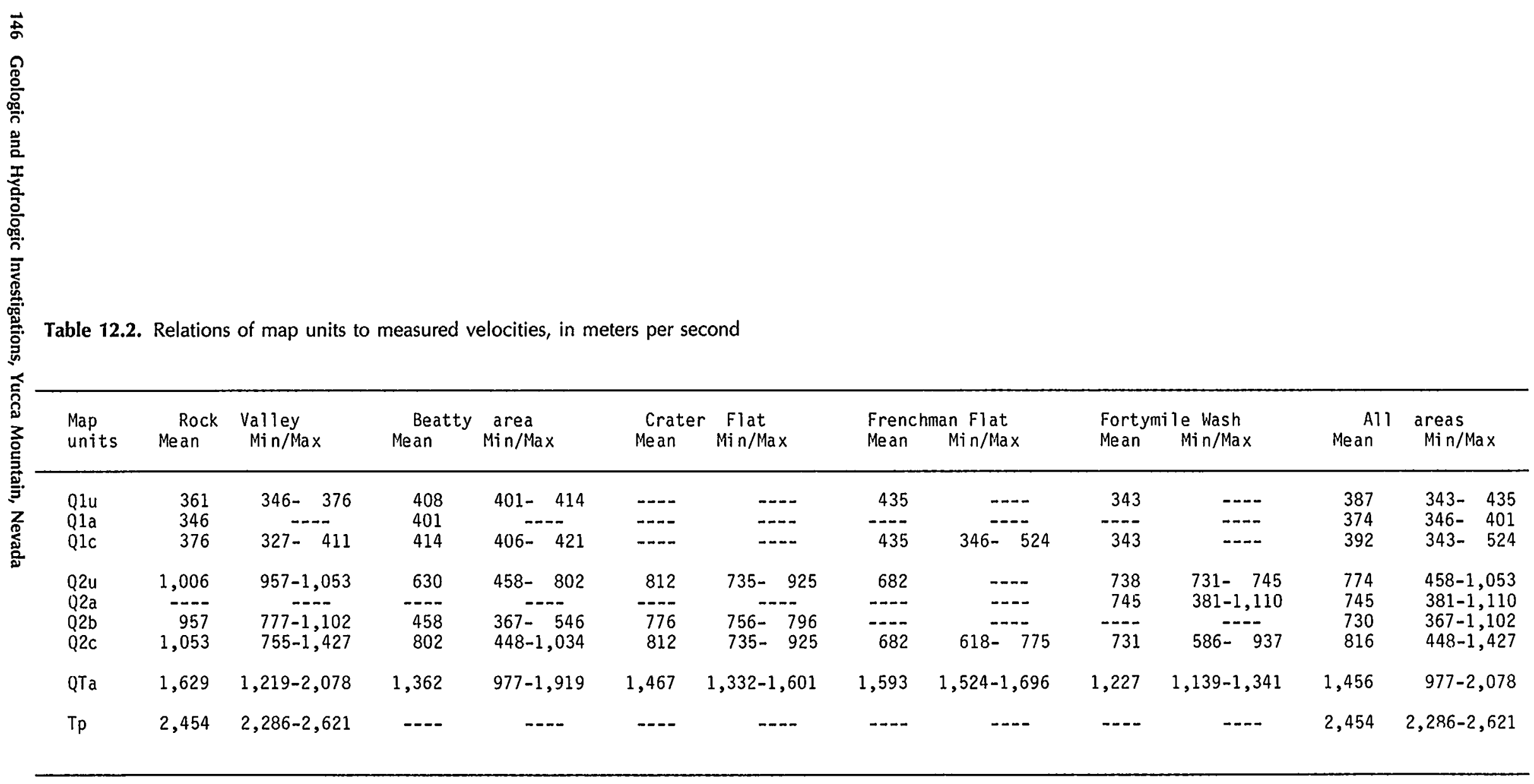




\title{
13. Water-Table Decline in the South-Central Great Basin During the Quaternary: Implications for Toxic Waste Disposal
}

\author{
By Isaac J. Winograd and Barney J. Szabo
}

\section{CONTENTS}

\author{
Abstract 147 \\ Introduction 147 \\ Acknowledgments 148 \\ Rates of apparent water-table decline 148 \\ Discussion and synthesis $\mathbf{1 5 0}$ \\ Implications for toxic waste disposal 151 \\ References cited 152
}

\begin{abstract}
The distribution of vein calcite, tufa, and other features indicative of paleo-ground-water discharge indicates that during the early and middle Pleistocene the water table at Ash Meadows, in the Amargosa Desert, Nevada, and at Furnace Creek Wash, in east-central Death Valley, California, was tens to hundreds of meters above the modern water table, and that ground-water discharge occurred up to $18 \mathrm{~km}$ up the hydraulic gradient from modern discharge areas. Uranium-series dating of the calcitic veins permits calculation of rates of apparent watertable decline; rates of 0.02 to $0.08 \mathrm{~m} / \mathrm{ka}$ are indicated for Ash Meadows and 0.2 to $0.6 \mathrm{~m} / \mathrm{ka}$ for Furnace Creek Wash. The rates for Furnace Creek Wash closely match a published estimate of vertical crustal offset for this area, suggesting that tectonism is a major cause for the displacement observed. In general, displacements of the paleo water table probably reflect a combination of (1) tectonic uplift of vein calcite and tufa, unaccompanied by a change in water-table altitude, (2) decline in water-table altitude in response to tectonic depression of areas adjacent to dated veins and associated tufa, (3) decline in watertable altitude in response to increasing aridity caused by major uplift of the Sierra Nevada and Transverse Ranges during the Quaternary, and (4) decline in water-table altitude in response to erosion triggered by increasing aridity and (or) tectonism.

A synthesis of hydrogeologic, neotectonic, and paleoclimatologic information with the vein-calcite data permits the inference that the water table in the south-central Great Basin progressively lowered throughout the Quaternary. This inference is pertinent to an evaluation of the utility of thick (200-600 m) unsaturated zones of the region for isolating solidified radioactive wastes from the hydrosphere for hundreds of millenia. Wastes buried a few tens to perhaps $100 \mathrm{~m}$ above the modern water table-that is above possible water level rises due to future pluvial
\end{abstract}

climates-are unlikely to be inundated by a rising water table in the foreseeable geologic future.

\section{INTRODUCTION}

Regional interbasin flow of ground water through the thick section of Paleozoic carbonate rocks of the south-central Great Basin has been the subject of numerous studies in the past 25 years (Hunt and Robinson, 1960; Loeltz, 1960; Winograd, 1962, Winograd and Thordarson, 1968; Winograd, 1971; Winograd and Friedman, 1972; Naff, 1973; Winograd and Thordarson, 1975; Dudley and Larson, 1976; Winograd and Pearson, 1976; Waddell, 1982). Flow through the regional carbonate-rock aquifer is directed toward major spring discharge areas at Ash Meadows in the Amargosa Desert of Nevada and toward Furnace Creek Wash in east-central Death Valley, California (fig. 13.1). The flow occurs under hydraulic gradients as low as $0.06 \mathrm{~m} / \mathrm{km}$ (Winograd and Thordarson, 1975, pl. I), reflecting the high fracture transmissivity of this aquifer. Locally, major hydraulic barriers compartmentalize the aquifer (Winograd and Thordarson, 1968, 1975). A detailed hydrogeologic and hydrogeochemical synthesis of this vast flow system, including potentiometric maps, is available in Winograd and Thordarson (1975).

A variety of geologic evidence indicates that during the Pleistocene the water table in the regional carbonate-rock aquifer at Ash Meadows and at Furnace Creek Wash (fig. 13.1) was tens to hundreds of meters above the modern water table (Winograd and Doty, 1980). The evidence consists of tufas; ancient spring orifices; calcitic veins and cyclindrical calcite-lined tubes that mark the routes of paleo ground water flow to spring orifices; and paleo water levels inscribed on the walls of Devils Hole (fig. 13.1), a fault-controlled collapse feature adjacent to the Ash Meadows discharge area. Most of these have been briefly described elsewhere (Winograd and Thordarson, 1975, p. C82-C83; Winograd and Doty, 1980; Pexton, 1984; Winograd and others, 1985). In this study we focus on the calcitic veins as indicators of paleo water tables because they are readily datable using uranium-disequilibrium methods (Szabo and others, 1981; Winograd and others, 1985) This report is an initial step toward a quantification of the observations of Winograd and Doty (1980). 


\section{Acknowledgments}

We thank D. Stuart-Alexander, W.J. Carr, W.W. Dudley, Jr., W.R. Osterkamp, N.J. Trask, Jr., R.B. Scott, and W.E. Wilson for helpful review comments, and we appreciate the excellent assistance provided by G.C. Doty and A.C. Riggs during the field search for the calcitic veins.

\section{RATES OF APPARENT WATER-TABLE DECLINE}

At Ash Meadows, the calcitic veins occur in association with, and adjacent to, a structurally controlled $16-\mathrm{km}$ long spring discharge area (Winograd and Thordarson, 1975). The veins occur as much as $50 \mathrm{~m}$ higher than and as much as $14 \mathrm{~km}$ up the hydraulic gradient from the highest water level (altitude $719 \mathrm{~m}$ ) at Ash Meadows-namely, that in Devils Hole (Winograd and Doty, 1980). Veins AM-7, DH-1, and AM-10 from Ash Meadows and northern Amargosa Flat (fig. 13.1) are, respectively, 11, 19, and $26 \mathrm{~m}$ higher than the water level in Devils Hole (table 13.1). (The hydraulic gradient in the region between these veins is extremely small $-0.06 \mathrm{~m} / \mathrm{km}$ (Winograd and Thordarson, 1975, pl. I) - so that for practical purposes the altitude of the veins can be compared directly to the water level in Devils Hole.) Uranium-disequilibrium dating of these veins yields an age of $510 \pm 62 \mathrm{ka}$ for the youngest laminae in vein AM-7, $660 \pm 75 \mathrm{ka}$ for the youngest laminae in vein $\mathrm{DH}-1$, and $750 \pm 52 \mathrm{ka}$ for the center of vein AM-10 (table 13.1). These data permit calculation of the average rates of apparent water-
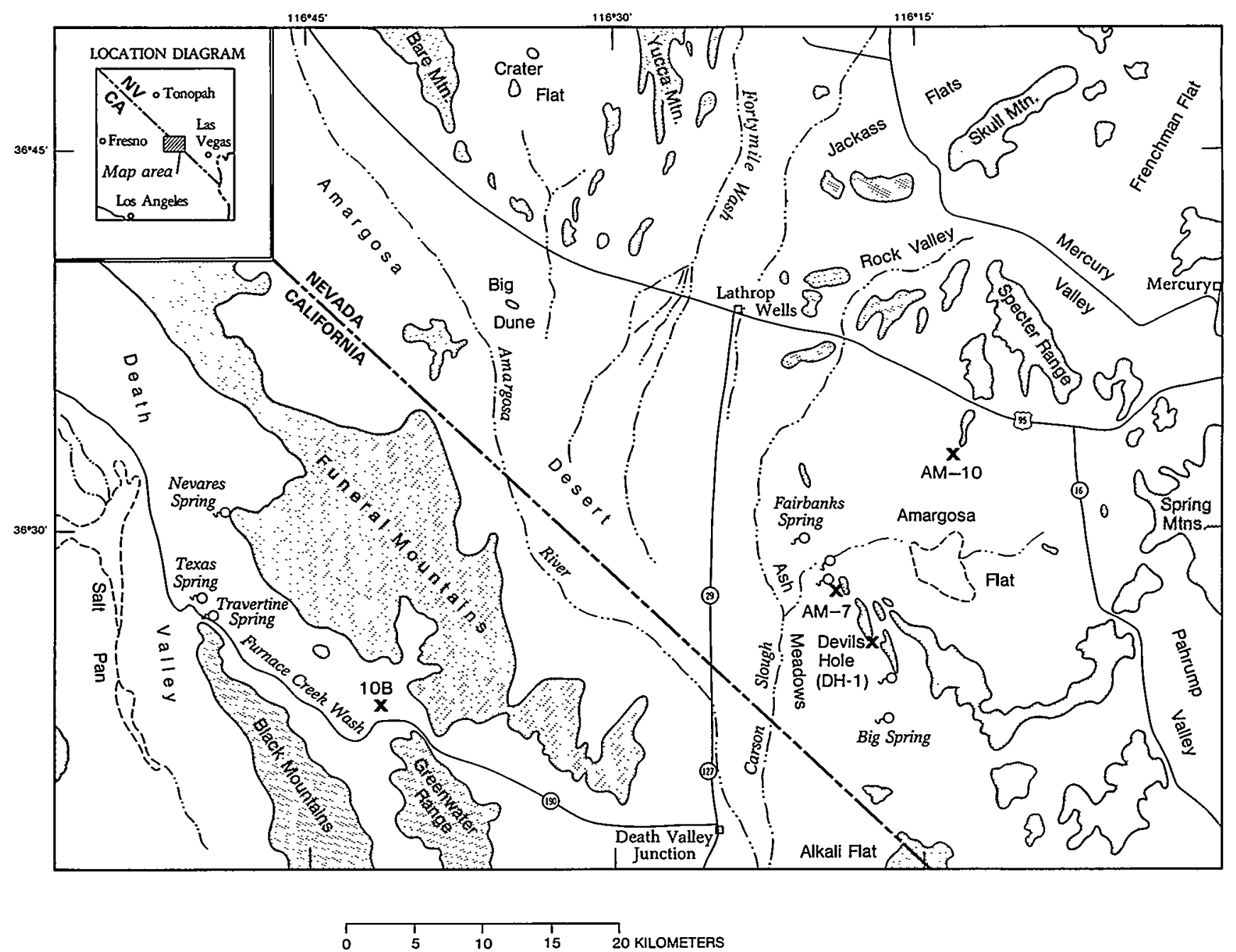

Figure 13.1. Index map of south-central Great Basin, Nevada-California. Uplands shaded; x's mark location of uranium-series dated calcitic veins discussed in text. 
table decline; rates on the order 0.02 to $0.03 \mathrm{~m} / \mathrm{ka}$ are indicated (table 13.1). These rates are minimum values, first, because we do not know how high above outcrop the sampled veins might have extended prior to erosion; and second, because the youngest laminae in our veins may only record the time of sealing of the vein, rather than the time of cessation of ground-water discharge. Nevertheless, because the numerator (that is the altitude difference between vein outcrop and water level in Devils Hole) in our ratio is so much smaller than the denominator (vein age), any reasonable combination of values yields a very slow rate of decline. For example, if the altitude of vein $\mathrm{DH}-1$ were $20 \mathrm{~m}$ higher prior to erosion (a large value considering the present relief on the Pliocene and Pleistocene rocks in central Ash Meadows) and if ground-water discharge ceased $400 \mathrm{ka}$ instead of $660 \mathrm{ka}$ ago, we still calculate an apparent rate of water-table decline which is less than $0.1 \mathrm{~m} / \mathrm{ka}$.

The average rates of water-table decline cited above ( 0.02 to $0.03 \mathrm{~m} / \mathrm{ka}$ ) were calculated (table 13.1 , columns 1-5) assuming a constant rate of decline during the middle and late Pleistocene, that is over times 510 to $750 \mathrm{ka}$ long. A more realistic computation of decline rate is one involving three vein pairs that differ in age by only 90 to $240 \mathrm{ka}$. Such a computation (table 13.1, columns 6-7) yields rates of decline which are 2 to $21 / 2$ times as large as the average rates, namely 0.05 to $0.08 \mathrm{~m} / \mathrm{ka}$. The paired veins record ground-water flow in the period $510 \mathrm{ka}$ to $750 \mathrm{ka}$ (table 13.1). When these data are arranged by decreasing age and are coupled with the average rate of decline calculated for the past $510 \mathrm{ka}(0.02 \mathrm{~m} / \mathrm{ka}$, derived from the youngest and lowest vein, AM-7, and the water-table altitude in Devils Hole), we see a suggestion of a possible reduction in rate of watertable decline during the middle Pleistocene; that is, a rate of $0.08 \mathrm{~m} / \mathrm{ka}$ is indicated for the period 750 to $660 \mathrm{ka}$, a rate of $0.05 \mathrm{~m} / \mathrm{ka}$ for the period 660 to $510 \mathrm{ka}$ and a rate of $0.02 \mathrm{~m} / \mathrm{ka}$ for the past $510 \mathrm{ka}$. In view of the caveats presented in the preceding paragraph, additional work is clearly in order to verify the suggested change in rate of water-table decline in the Ash Meadows region. In summary, the data of table 13.1 indicate rates of apparent water decline of 0.02 to $0.08 \mathrm{~m} / \mathrm{ka}$ for the Ash Meadows-Amargosa Flat area.

At Furnace Creek Wash (fig. 13.1), the rate of lowering of the water table during the Quaternary is an order of magnitude greater than the cited rates for Ash Meadows and vicinity. Here a calcitic vein swarm and associated tufa occur at an altitude of about $855 \mathrm{~m}$. Uranium-disequilibrium dating of vein 10B (fig. 13.1) from this area indicates that groundwater flow in the fracture containing this vein ceased about $1,000 \pm 100 \mathrm{ka}$. In the absence of wells or artesian springs, the water-table altitude in the regional carbonate aquifer beneath the vein swarm is unknown, but we can bracket the range of possible water-table altitudes by reference to known water levels both up and down the hydraulic gradient from the vein swarm. The altitude of the water table in the valleyfill aquifer beneath the southern Amargosa Desert, 15-20 $\mathrm{km}$ up the hydraulic gradient from the vein swarm, is about 640-670 m (Winograd and Thordarson, 1975, pl. I), or about $185-215 \mathrm{~m}$ lower than the vein swarm $(855 \mathrm{~m})$. The altitude of the water table in the regional carbonate aquifer at Nevares Spring (fig. 13.1) in east-central Death Valley, $18 \mathrm{~km}$ down the hydraulic gradient, is $286 \mathrm{~m}$ or about $570 \mathrm{~m}$ lower than the vein swarm. (The water level at Nevares Spring is the highest level known for the regional carbonate aquifer in eastcentral Death Valley.) Due to the extreme aridity of the region, plus the high transmissivity of the regional carbonate aquifer (Winograd and Thordarson, 1975), the presence of a ground-water mound (a potentiometric high) in the

Table 13.1. Uranium-disequilibrium ages of calcitic veins at Ash Meadows and Amargosa Flat, Nevada, and rates of apparent watertable decline during the Quaternary

[Altitude of vein AM-10 estimated from USGS 1:24,000 Specter Range, SW topographic quadrangle; altitude DH-1 from laser-altimeter survey; altitude AM-7 from average of four aneroid-barometer surveys. Justification for dating the calcitic veins by the ${ }^{234} U{ }^{238} U$ method in Winograd and others (1985). Average rate of water-table decline assumes constant rate of decline between time of deposition of youngest laminae in vein and the Holocene; values rounded to one significant figure and represent minimum rates for reasons given in text]

\begin{tabular}{|c|c|c|c|c|c|c|}
\hline $\begin{array}{l}\text { Vein } \\
\text { (see fig. 13.1 } \\
\text { for location) }\end{array}$ & $\begin{array}{l}\text { Altitude } \\
\text { (m) }\end{array}$ & $\begin{array}{c}{ }^{234} \mathrm{U} /{ }^{238} \mathrm{U} \\
\text { age } \\
\text { (ka) }\end{array}$ & $\begin{array}{l}\text { Vein altitude above } \\
\text { water-level at Devils } \\
\text { Hole }(719 \mathrm{~m}) \\
(\mathrm{m})\end{array}$ & $\begin{array}{l}\text { Average rate of } \\
\text { water-table } \\
\text { decline } \\
(\mathrm{m} / \mathrm{ka})\end{array}$ & $\begin{array}{c}\text { Difference in } \\
\text { altitude (m) } \\
\text { and in youngest } \\
\text { age (ka) for } \\
\text { indicated vein } \\
\text { pair }\end{array}$ & $\begin{array}{l}\text { Rate of water- } \\
\text { table decline } \\
\text { using data of } \\
\text { preceding column } 1 \\
\text { (m/ka) }\end{array}$ \\
\hline $\mathrm{AM}-10-1-2$ & $\begin{array}{l}745 \pm 3 \\
738\end{array}$ & $\begin{array}{l}2750 \pm 52 \\
660 \pm 75 \text { to } \\
890 \pm 92\end{array}$ & $\begin{array}{l}26 \pm 3 \\
19\end{array}$ & $\begin{array}{r}0.03 \\
.03\end{array}$ & $\begin{array}{l}\text { 7, } 90(\text { AM 10-DH 1) } \\
15,240(\text { AM 10-AM 7) }\end{array}$ & $\begin{array}{r}0.08 \\
.06\end{array}$ \\
\hline AM-7- & $730 \pm 1$ & $\begin{array}{l}510 \pm 62 \text { to } \\
620 \pm 66\end{array}$ & $11 \pm 1$ & .02 & $8,150(\mathrm{DH} \quad 1-\mathrm{AM} 7)$ & .05 \\
\hline
\end{tabular}

\footnotetext{
Values rounded to one significant figure.

${ }^{2}$ Sample came from center of $1-\mathrm{cm}-\mathrm{thick}$ vein; given average growth rates $(0.3 \mathrm{~mm} / \mathrm{ka})$ in other Ash Meadows veins, the time spanned during deposition of this very thin vein is unlikely to have exceeded $50 \mathrm{ka}$. (We assume the vein grew symmetrically from the walls.)
} 
carbonate aquifer between the southern Amargosa Desert and east-central Death Valley is extremely remote; that is, we have confidence that the potentiometric surface in the carbonate aquifer beneath the vein swarm at Furnace Creek Wash is intermediate between the cited altitudes in the southern Amargosa Desert and in east-central Death Valley. The uranium-disequilibrium age, in conjuction with the cited vein and water-table altitudes, indicates an average watertable lowering of 0.2 to $0.6 \mathrm{~m} / \mathrm{ka}$.

\section{DISCUSSION AND SYNTHESIS}

Tectonics, climate change, and erosion in response to tectonics and (or) climate change are obvious potential causes for the observed water-table displacements. A comparison of the cited water-table displacement rates at Ash meadows $(0.02$ to $0.08 \mathrm{~m} / \mathrm{ka})$ and Furnace Creek Wash $(0.2$ to 0.6 $\mathrm{m} / \mathrm{ka}$ ) with average rates of vertical crustal offsets in these regions seemingly supports tectonism as a major cause for the displacement we have observed at Furnace Creek Wash. In east-central Death Valley, a rate of vertical crustal offset of $0.3 \mathrm{~m} / \mathrm{ka}$ has been calculated by Carr (1984) for the Black Mountains (fig. 13.1) utilizing the data of Fleck (1970). In contrast, data presented by Pexton (1984, p. 49) on the displacement of a 3-m.y.-old tuff at Ash Meadows indicate relative vertical crustal offset of about $0.01 \mathrm{~m} / \mathrm{ka}$, or onehalf to one-eighth of the indicated rate of water-table decline at Ash Meadows and vicinity.

Climatic change cannot be discounted as an important auxiliary cause for the documented water-table displacements. Major uplift of the Sierra Nevada and Transverse Ranges during the Pliocene and Quaternary should have markedly and progressively reduced the precipitation reaching the Great Basin during this time. Smith and others (1983, p.23) suggested that $3 \mathrm{~m} . \mathrm{y}$. ago, when the Sierra Nevada was about $950 \mathrm{~m}$ lower, about 50 percent more moisture might have crossed the Sierra and moved into the Great Basin. Various lines of evidence support such notions. Raven and Axelrod (1977) and Axelrod (1979), using paleobotanical evidence, argued for increasing aridity in the Great Basin, Mojave Desert, and Sonoran Desert during the late Tertiary and Quaternary. They attributed this increasing aridity to uplift of the Sierra Nevada, Transverse Ranges, Peninsular Ranges, and the Mexican Plateau. Winograd and others (1985) described a major and progressive depletion in the deuterium content of ground-water recharge in the region during the Quaternary; the most logical explanation for their data is a progressive decrease in Pacific moisture due to uplift of the Sierra Nevada and Transverse Ranges. And Pexton (1984, p. 43-46, 57), on the basis of studies of sediment depositional environments, believed that the Ash Meadows area became progressively more arid during the Quaternary.

The role of erosion in the apparent lowering of the water table is not known. We assume that in east-central
Death Valley, where the rate of vertical crustal offset is large, tectonism dominated both erosion and climate as a factor in water-table change during the Quaternary. This may not, however, be correct for the Ash Meadows region, where the rate of vertical crustal offset is an order of magnitude smaller (see above); here, the erosional history of the bordering Amargosa Desert-a history influenced by climate change and possibly also by tectonism in Death Valley-may have played an important role in the water-table changes we see at and northeast of Ash Meadows.

We should emphasize that the evidence presented by Winograd and Doty (1980), and its initial quantification herein, suggests only an apparent lowering of the water table during the Quaternary at Ash Meadows and Furnace Creek Wash. We do not know to what degree the displacement of veins and tufas relative to the modern water table reflects (1) tectonic uplift of the veins and associated tufas, unaccompanied by a decline in water-table altitude; (2) a lowering of water-table altitude in response to the tectonic downdropping of a region adjacent to the veins and tufas; (3) a lowering of water-table altitude in response to increasing aridity, or to erosion; or (4) some combination of these. Locally, uplift of the veins was probably a major cause for the displacements we observed. For example, the occurrence of the veins at Furnace Creek Wash (site 10B, fig. 13.1) at altitudes higher than the modern potentiometric surfaces to the west and east (see above) strongly suggests that major uplift of the Funeral Mountains and Greenwater Range occurred relative to both Death Valley on the west and the Amargosa Desert on the east. However, a synthesis of regional hydrogeologic, tectonic, and paleoclimatologic information with our observations indicates that a progressive and absolute lowering of the regional water table (more correctly the potentiometric surface) is likely to have occurred throughout the south-central Great Basin during the Quaternary. This inference is based on the following three considerations. (1) The several-thousand-meter topographic relief in Death Valley developed principally during the Pliocene and Pleistocene (Hunt and Mabey, 1966; U.S. Geological Survey, 1984), and the movement of the floor of Death Valley has probably been downward relative both to sea level and to bordering areas (Hunt and Mabey, 1966, p. A153). (2) Gravity-driven interbasin flow of ground water through the carbonate-rock aquifer is widespread in the region today (Winograd and Thordarson, 1975) and is directed toward Ash Meadows and Death Valley. Such interbasin flow of ground water toward Death Valley in all likelihood also occurred during the Quaternary in response to the progressive lowering of ground-water discharge outlets there. (3) The progressive increase in aridity of the region, due to uplift of the Sierra Nevada and Transverse Ranges, would presumably have resulted in a progressive reduction in ground-water recharge.

We are aware that the regional carbonate-rock aquifer is hydraulically compartmentalized by faulting (Winograd and Thordarson, 1975, p. C63-C71) and that, consequently, 
the postulated lowering of ground-water base level in Death Valley during the Quaternary may not have propagated uniformly throughout the region, specifically northeast of the major hydraulic barrier at Ash Meadows (Winograd and Thordarson, 1975, p. C78-C83). Nevertheless, we believe that the combination of increasing aridity and local erosion in the Amargosa Desert during the Quaternary should, in any event, have resulted in a progressive lowering of the water table at and northeast of Ash Meadows.

Yet another mechanism for water-table lowering at and northeast of Ash Meadows that involves neither erosion nor climate change, but rather extensional fracturing, was outlined by Winograd and Doty (1980). They pointed out (p. 74-75) that the major springs at Ash Meadows oasis differ in altitude by as much as $35 \mathrm{~m}$ and are as much as $50 \mathrm{~m}$ lower than the water level in Devils Hole. Thus, periodic initiation of discharge from new spring orifices (or an increase in existing discharge) in the lower portions of this oasis due to faulting would have resulted in new and lower base levels for ground-water discharge. Implicit in their hypothesis is the belief that the faulting would be of extensional nature, opening new (or widening old) avenues of discharge from the buried Paleozoic carbonate-rock aquifer which underlies eastern Ash Meadows and which feeds all the modern springs (Winograd and Thordarson, 1975). In support of their hypothesis, we note that most of the calcitic veins in Pliocene and younger rocks at Ash Meadows strike N. $40^{\circ} \pm 10^{\circ} \mathrm{E}$., that is, nearly at right angles to Carr's (1974) estimate of the direction of active extension in region, namely $\mathrm{N} .50^{\circ} \mathrm{W}$. This mechanism may also have periodically lowered the water table in east-central Death Valley (fig. 13.1) where the difference in altitude between the highest (Nevares) and lowest (Texas) major springs discharging from the regional carbonate aquifer is about $170 \mathrm{~m}$ (Winograd and Thordarson, 1975, p. C95-C97).

Our evidence for water-table decline pertains only to the Paleozoic carbonate-rock aquifer, the "Lower carbonate aquifer" of Winograd and Thordarson (1975, table 1). As mentioned in the introduction, this regional aquifer serves as a gigantic "tile field" which integrates the flow of ground water from perhaps as many as 10 intermountain basins (Winograd and Thordarson, 1975). The water-table altitude in this regional aquifer system presently exerts a major control on the altitude of the potentiometric surface in locally overlying Cenozoic welded tuff and valley-fill aquifers (Winograd and Thordarson,1975, p. C53-C63, and pl. I). Accordingly, we suggest further that the progressive watertable decline postulated for the regional carbonate aquifer during the Quaternary was accompanied by a decline in water-table altitude in the overlying welded tuff and valleyfill aquifers of the region.

The suggested progressive lowering of the regional water table throughout the Quaternary does not preclude superimposed and relatively rapid cyclical fluctuations in water level in response to the glacial (that is, pluvial) and interglacial climates of the Pleistocene. Indeed, preliminary data from Devils Hole indicate that the water table in the carbonate aquifer may have fluctuated as much as $10 \mathrm{~m}$ in the past $30 \mathrm{ka}$ (A.C. Riggs and B.J. Szabo, oral communication, December 1986). This, in turn, indicates that vein AM-7 (see above), which is only $11 \mathrm{~m}$ above the modern water table, would by itself be of limited utility for determination of the postulated water-table decline since the middle Pleistocene. Intensive studies of paleo water level fluctuations are underway in Devils Hole where excellent records of both Quaternary paleohydrology and paleoclimatology are preserved. We hope that these studies will permit us to distinguish between short-term (1-10 ka) and long-term (100-1,000 ka) water-table fluctuations at Ash Meadows and vicinity where the difference between the highest dated paleo water level and the highest modern water table is only $26 \mathrm{~m}$ (table 13.1).

\section{IMPLICATIONS FOR TOXIC WASTE DISPOSAL}

The cited evidence for an apparent lowering of the water table at Ash Meadows and Furnace Creek Wash and the inference of an absolute lowering of water table in the south-central Great Basin during the Quaternary are pertinent to an evaluation of the utility of the thick (200-600 m) unsaturated zones of the region for isolating solidified radioactive and toxic wastes from the hydrosphere for tens to hundreds of millenia (Winograd, 1981). Important information which must be obtained before using such zones for toxic waste disposal is the magnitude of water-table rise that occurred during past pluvial climates of the Pleistocene; such information would, by extension, provide clues to the likelihood of buried toxic wastes being inundated by a future rise of the water table. Winograd and Doty (1980) and Czarnecki (1985), using worst-case assumptions, suggested possible pluvial-related water-table rises of several tens of meters to $130 \mathrm{~m}$ above the modern water table in Frenchman Flat and beneath Yucca Mountain (fig. 13.1). As noted in the preceding section, we have preliminary information suggesting a late Wisconsin water-table rise on the order of $10 \mathrm{~m}$ in the carbonate aquifer at Devils Hole. Thus, it appears that solidified wastes emplaced in the thick (200-600 m) unsaturated zones of the region-at levels a few tens to a hundred meters or so above the water table-should not be inundated by a rising water table during future pluvial climates. (The depth of placement within the unsaturated zone would, or course, be chosen to preclude exhumation of the wastes by erosion.) Moreover, if our inference of a progressive lowering of water table during the Quaternary is sustained by ongoing studies of the carbonate rock and other aquifers, then it is likely that wastes buried in the unsaturated zone will in any event become increasingly displaced from the water table in the foreseeable geologic future. That is, the continuing uplift of the Sierra Nevada (Huber, 1981) and Transverse Ranges, and lowering of Death Valley (Hunt and Mabey, 1966, p. A100-A116), relative to surrounding 
regions, should result in a continued progressive decline of the regional water table in the next 100,000 to 1 million yr (and beyond?) in response to increasing aridity and to lowering of ground-water base level.

\section{REFERENCES CITED}

Axelrod, D.I., 1979, Age and origin of Sonoran Desert vegetation: California Academy of Science, Occasional Papers, no. 132,74 p.

Carr, W.J., 1974, Summary of tectonic and structural evidence for stress orientation at the Nevada Test Site: U.S. Geological Survey Open-File Report 74-176, 53 p.

1984, Regional structural setting of Yucca Mountain, southwestern Nevada, and late Cenozoic rates of tectonic activity in part of the southwestern Great Basin, Nevada and California: U.S. Geological Survey Open-File Report 84-854, $109 \mathrm{p}$.

Czarnecki, J.B., 1985, Simulated effects of increased recharge on the ground water flow system of Yucca Mountain and vicinity, Nevada-California: U.S. Geological Survey Water Resources Investigations Report 84-4344, 33 p.

Dudley, W.W., Jr., and Larson, J.D., 1976, Effect of irrigation pumping on desert pupfish habitats in Ash Meadows, Nye County, Nevada: U.S. Geological Survey Professional Paper 927, $52 \mathrm{p}$.

Fleck, R.J., 1970, Age and tectonic significance of volcanic rocks, Death Valley area, California: Geological Society of America Bulletin, v. 81 , p. 2807-2816.

Huber, N.K., 1981, Amount and timing of late Cenozoic uplift and tilt of the central Sierra Nevada, California-Evidence from the upper San Joaquin River basin: U.S. Geological Survey Professional Paper 1197, 28 p.

Hunt, C.B., and Mabey, D.R., 1966, Stratigraphy and structure of Death Valley, California: U.S. Geological Survey Professional Paper 494-A, $162 \mathrm{p}$.

Hunt, C.B., and Robinson, T.W., 1960, Possible interbasin circulation of ground water in the southern part of the Great Basin, in Short papers in the geological sciences: U.S. Geological Survey Professional Paper 400-B, p. B273-B274.

Loeltz, O.J., 1960, Source of water issuing from springs in Ash Meadows Valley, Nye County, Nevada: Geological Society of America Bulletin, v. 71, no. 12, pt. 2, p. 1917-1918.

Naff, R.L., 1973, Hydrogeology of the southern part of Amargosa Desert in Nevada: Reno, University of Nevada, M.S. thesis, $207 \mathrm{p}$.

Pexton, R.E., 1984, Geology and paleohydrology of a part of the Amargosa Desert, Nevada: Berkeley, University of California, M.S. thesis.

Raven, P.H., and Axelrod, D.I., 1977, Origin and relationships of the California flora: University of California, Publications in Botany, v. 72, 134 p.

Smith, G.I., Barczak, V.J., Moulton, G.F., and Liddicoat, J.C., 1983, Core KM-3, a surface to bedrock record of late Cenozoic sedimentation in Searles Valley, California: U.S. Geological Survey Professional Paper 1256, 24 p.

Szabo, B.J., Carr, W.J., and Gottschall, W.C., 1981, Uraniumthorium dating of Quaternary carbonate accumlations in the Nevada Test Site region, southern Nevada: U.S. Geological Survey Open-File Report 81-119, 33 p.

U.S. Geological Survey, 1984, A summary of geologic studies through January 1, 1983, of a potential high-level radioactive waste repository at Yucca Mountain, southern Nye county, Nevada: U.S. Geological Survey Open-File Report 84-792.

Waddell, R.K., 1982, Two dimensional, steady-state model of ground-water flow, Nevada Test Site and vicinity, NevadaCalifornia: U.S. Geological Survey Water Resources Investigations Report 82-4085, 72 p.

Winograd, I.J., 1962, Interbasin movement of ground water at the Nevada Test Site, Nevada, in Short papers in geology and hydrology: U.S. Geological Survey Professional Paper 450-C, p. C108-C111.

1971, Origin of major springs in the Amargosa Desert of Nevada and Death Valley, California: Tucson, University of Arizona, Ph.D. dissertation, 170 p.

1981, Radioactive waste disposal in thick unsaturated zones: Science, v.212, p. 1457-1464 (Discussion in v. 215, p. 914).

Winograd, I.J., and Doty, G.C., 1980, Paleohydrology of the southern Great Basin with special reference to water table fluctuations beneath the Nevada Test Site during the late(?) Pleistocene: U.S. Geological Survey Open-File Report 80-569, $91 \mathrm{p}$.

Winograd, I.J., and Friedman, Irving, 1972, Deuterium as a tracer of regional ground-water flow, southern Great Basin, NevadaCalifornia: Geological Society of America Bulletin, v. 83, no. 12 , p. 3691-3708.

Winograd, I.J., and Pearson, F.J., Jr., 1976, Major carbon 14 anomaly in a regional carbonate aquifer: Possible evidence for mega scale channeling, south-central Great Basin: Water Resources Research, v. 12, No. 6, p. 1125-1143.

Winograd, I.J., Szabo, B.J., Coplen, T.B., Riggs, A.C., and Kolesar, P.T., 1985, Two-million-year record of deuterium depletion in Great Basin ground waters: Science, v. 227, p. 519-522.

Winograd, I.J., and Thordarson, William, 1968, Structural control of ground-water movement in miogeosynclinal rocks of south-central Nevada, in Eckel, E.B., ed., Nevada Test Site: Geological Society of America Memoir 110, p. 35-48.

1975, Hydrogeologic and hydrochemical framework, southcentral Great Basin, Nevada-California, with special reference to the Nevada Test Site: U.S. Geological Survey Professional Paper 712-C, 126 p. 